\title{
De Limburgse arbeidsmarkt 1997-2002
}

Citation for published version (APA):

van Eijs, P. W. L. J., de Grip, A., Delmee, J., \& van Loo, J. B. (1998). De Limburgse arbeidsmarkt 19972002. Researchcentrum voor Onderwijs en Arbeidsmarkt, Faculteit der Economische Wetenschappen. ROA Reports No. 3 https://doi.org/10.26481/umarep.1998003

Document status and date:

Published: 01/01/1998

DOI:

10.26481/umarep.1998003

Document Version:

Publisher's PDF, also known as Version of record

\section{Please check the document version of this publication:}

- A submitted manuscript is the version of the article upon submission and before peer-review. There can be important differences between the submitted version and the official published version of record.

People interested in the research are advised to contact the author for the final version of the publication, or visit the DOI to the publisher's website.

- The final author version and the galley proof are versions of the publication after peer review.

- The final published version features the final layout of the paper including the volume, issue and page numbers.

Link to publication

\footnotetext{
General rights rights.

- You may freely distribute the URL identifying the publication in the public portal. please follow below link for the End User Agreement:

www.umlib.nl/taverne-license

Take down policy

If you believe that this document breaches copyright please contact us at:

repository@maastrichtuniversity.nl

providing details and we will investigate your claim.
}

Copyright and moral rights for the publications made accessible in the public portal are retained by the authors and/or other copyright owners and it is a condition of accessing publications that users recognise and abide by the legal requirements associated with these

- Users may download and print one copy of any publication from the public portal for the purpose of private study or research.

- You may not further distribute the material or use it for any profit-making activity or commercial gain

If the publication is distributed under the terms of Article $25 \mathrm{fa}$ of the Dutch Copyright Act, indicated by the "Taverne" license above, 
De Limburgse arbeidsmarkt 1997-2002

ROA-R-1998/3

P. van Eijs

A. de Grip

J. Delmee

J. van Loo

Researchcentrum voor Onderwijs en Arbeidsmarkt

Faculteit der Economische Wetenschappen en Bedrijfskunde Universiteit Maastricht

Maastricht, maart 1998 
ISBN 90-

SEC97.179/PvE 


\section{Ten geleide}

Van verschillende kanten is er een behoefte aan betrouwbare informatie over de actuele en toekomstige arbeidsmarktsituatie in Limburg. Deze informatiebehoefte vormde de aanleiding tot het project Regionale Arbeidsmarkt Informatie Limburg (RAIL), dat beoogt te komen tot een geïntegreerd informatiesysteem toegespitst op de provincie Limburg. In het RAIL-project participeren Arbeidsvoorziening Limburg, de Provincie Limburg, RBO Zuid-Limburg, de Regionale Opleidingscentra (ROC's), de FNV en de Limburgse Werkgevers Vereniging (LWV). Er wordt derhalve samengewerkt door een aantal partners die zowel gebruiker als leverancier van informatie zijn.

Het thans voor U liggende rapport De Limburgse arbeidsmarkt 1997-2002 en de bijbehorende Statistische Bijlage vormt het overzichtrapport dat het Researchcentrum voor Onderwijs en Arbeidsmarkt (ROA) heeft samengesteld op basis van de in de ontwikkelfase van RAIL gegenereerde en verzamelde informatie. Deze informatie is primair gericht op het in kaart brengen van de actuele en toekomstige discrepanties naar bedrijfssector, beroep en opleiding op de Limburgse arbeidsmarkt.

Teneinde de discrepanties zo goed mogelijk in kaart te brengen omvat het informatiesysteem een drietal elementen. In de eerste plaats wordt er een zo breed mogelijk beeld gegeven van de actuele Limburgse arbeidsmarktsituatie. In de tweede plaats worden er korte-termijnprognoses van vraag en aanbod op de Limburgse arbeidsmarkt gepresenteerd. In deze publicatie hebben deze korte-termijnprognoses betrekking op het jaar 1998. In de derde plaats wordt, aansluitend op de korte-termijnprognoses, aangegeven welke middellange-termijnontwikkelingen zich naar verwachting op de Limburgse arbeidsmarkt zullen voordoen. Deze middellange-termijnprognoses hebben in deze publicatie betrekking op het jaar 2002. Door zowel de huidige situatie als de toekomstige ontwikkelingen in kaart te brengen, heeft RAIL een signaleringsfunctie voor diverse gebruiksdoelen. Hierbij kan gedacht worden aan het personeels- en rekruteringsbeleid van werkgevers, het initiëren en bijsturen van bij- en omscholingsprogramma's voor werkzoekenden, de arbeidsbemiddeling, het (provinciale) arbeidsmarktbeleid en het onderwijsbeleid.

RAIL beoogt kwantitatieve arbeidsmarktinformatie met kwalitatieve informatie te integreren. Daarom heeft het, in opdracht van Arbeidsvoorziening Limburg, recent door het ETIL uitgevoerde kwalitatieve onderzoek naar de knelpunten op de Limburgse arbeidsmarkt in dit rapport een prominente plaats gekregen. Dit kwalitatieve onderzoek omvat een telefonische enquête onder circa 1.000 Limburgse bedrijven, twee panel-discussies met consulenten van Arbeidsvoorziening Limburg, twee panel-discussies met vertegenwoordigers van het beroepsonderwijs, veertien diepte-interviews bij middelgrote en grote bedrijven in Limburg en zeven diepte-interviews met intermediaire organisaties op het terrein van de arbeidsmarkt. Het kwalitatieve onderzoek was primair gericht op het in kaart brengen van de huidige en toekomstige discrepanties in twee speerpuntsectoren: de handel en de industrie. 
Het thans voor $U$ liggende rapport is het resultaat van de ontwikkelfase van RAIL. In deze ontwikkelfase heeft de nadruk gelegen op het verzamelen en genereren van informatie. In de toekomst zal meer en meer de aandacht worden gevestigd op de bouw van een informatiesysteem waarbinnen betrekkelijk eenvoudig nieuwe inzichten of meer recente statistische gegevens kunnen worden verwerkt, of delen van de exploitatie van het systeem door belanghebbenden zelf kunnen worden verricht.

In het voorliggende rapport wordt slechts in beperkte mate ingegaan op de gehanteerde onderzoeksmethoden, de gehanteerde classificaties, e.d.. Daarvoor wordt verwezen naar het werkdocument Methodiek Regionale Arbeidsmarkt Informatie Limburg (RAIL) 1997. Achterin dit rapport zijn enkele centrale begrippen uit dit rapport op een rij gezet en nader omschreven. Daarnaast wordt in het rapport, waar nodig, uitleg gegeven over de gebruiksmogelijkheden van de gepresenteerde informatie.

Het rapport bestaat uit een resumé en twee delen. De eerste vier hoofdstukken geven een overzicht van de huidige en toekomstige ontwikkelingen op de Limburgse arbeidsmarkt. In hoofdstuk 1 wordt een globaal overzicht gegeven van de belangrijkste arbeidsmarktontwikkelingen verbijzonderd naar bedrijfssector, beroepsgroep en opleidingstype ${ }^{1}$. De hoofdstukken 2, 3 en 4 omvatten de informatie gegroepeerd naar de drie bovengenoemde elementen van RAIL. Hoofdstuk 2 schetst een beeld van de actuele Limburgse arbeidsmarktsituatie. Naast de Limburgse werkgelegenheidsstructuur naar bedrijfssector, beroepsgroep en opleidingstype worden de actuele kwantitatieve en kwalitatieve discrepanties op de Limburgse arbeidsmarkt geanalyseerd. Hoofdstuk 3 gaat nader in op de te verwachten ontwikkelingen op de korte termijn aan zowel de vraag- als de aanbodzijde van de Limburgse arbeidsmarkt, hetgeen resulteert in een overzicht van de te verwachten discrepanties tussen vraag en aanbod op de verschillende segmenten van de arbeidsmarkt in 1998. Hoofdstuk 4 besteedt, analoog aan hoofdstuk 3, aandacht aan de te verwachten ontwikkelingen op de middellange termijn tot 2002.

Het tweede deel, dat bestaat uit de hoofdstukken 5, 6 en 7, biedt de informatie aan in een vorm die meer op specifieke gebruiksdoelen is toegespitst. Hoofdstuk 5 belicht de arbeidsmarktinformatie uit de voorgaande hoofdstukken vanuit het perspectief van de bedrijfssector. De informatie wordt gepresenteerd in de vorm van zogenaamde sectorfiches, voor respectievelijk de handel en de industrie; de twee sectoren waarop het kwalitatieve onderzoek was gericht. De nadruk ligt hierbij primair op het in kaart brengen van de knelpunten. In hoofdstuk 6 ligt de nadruk op de mogelijkheden om via scholing van de werkzoekenden de te verwachten discrepanties op de Limburgse arbeidsmarkt te verminderen. In dit hoofdstuk wordt een raamwerk gepresenteerd dat per

1. In dit rapport wordt gebruik gemaakt van een opleidingenclassificatie die gebaseerd is op de oude opleidingenstructuur. In de begrippenlijst achterin dit rapport wordt een relatie gelegd tussen de oude structuur en de bijbehorende benamingen en de nieuwe kwalificatiestructuur en de bijbehorende opleidingsaanduidingen zoals die zijn geformuleerd in de WEB. 
arbeidsmarktsegment inzicht verschaft in de onderliggende oorzaken van de kwantitatieve en kwalitatieve discrepanties op de Limburgse arbeidsmarkt. Bovendien biedt dit raamwerk de mogelijkheid deze inzichten te vertalen in richtlijnen voor bij- en omscholingsprogramma's. Dit hoofdstuk mondt dan ook uit in een overzicht van arbeidsmarktsegmenten, waarin bij- en omscholing van werkzoekenden een effectief beleidsinstrument kan vormen om de discrepanties op de Limburgse arbeidsmarkt te verminderen. In hoofdstuk 7 wordt de arbeidsmarktpositie van de verschillende opleidingen waarvoor er daadwerkelijk sprake is van een regionale arbeidsmarkt nader belicht. Het gaat hierbij om de opleidingen op VBO- en MBO/Leerlingwezen-niveau. Hierbij wordt met name nader ingegaan op de verwachte arbeidsmarktperspectieven op de middellange termijn, de conjunctuurgevoeligheid van de werkgelegenheid op de verschillende arbeidsmarktsegmenten en de uitwijkmogelijkheden op de arbeidsmarkt. Dit hoofdstuk mondt uit in een aantal richtlijnen voor het onderwijsbeleid uit oogpunt van de macrodoelmatigheid van het Limburgs onderwijs.

Onze dank gaat uit naar de leden van de RAIL-stuurgroep en -werkgroep. De volgende personen hebben hierin zitting: J. Crena de longh (DSM, voorzitter stuurgroep), G. Ahn (Arbeidsvoorziening Limburg, secretaris), M. te Baerts (Walram College Sittard), T. Beenackers-Oomen (RBO Zuid-Limburg), J. Dohmen (Leeuwenborgh Opleidingen), $\mathrm{H}$. Droppert (Arbeidsvoorziening Limburg), $\mathrm{H}$. Duijvestein (Arbeidsvoorziening Limburg), $\mathrm{H}$. de Jong (Provincie Limburg), W. Kohl (ROC Oostelijk Zuid-Limburg), J. Masschelein (Gildeopleidingen), J. Schobben (ROC Oostelijk Zuid-Limburg), M. van Smoorenburg (Arbeidsvoorziening Limburg), A. Snels (FNV Limburg), M. Wegerif (Arbeidsvoorziening Facilitair bedrijf, projectleider), G. Wolfs (Provincie Limburg) en L. Zeegers (LWV). 


\section{Resumé}

De actuele Limburgse arbeidsmarktsituatie

In Limburg waren, gemiddeld genomen, de afgelopen twee jaar 434.500 mensen werkzaam. Dit is ruim $7 \%$ van de werkzame bevolking in Nederland. De Limburgse werkgelegenheidsstructuur wijkt echter duidelijk af van het landelijke beeld. De industrie neemt in Limburg een veel belangrijkere plaats in dan in de rest van Nederland. In Limburg is bijna een kwart van de werkgelegenheid in de industrie te vinden; landelijk is dit slechts ongeveer $15 \%$. Met name de werkgelegenheid in de metaal- \& elektrotechnische industrie is in Limburg relatief hoog. In Limburg werkt bijna $14 \%$ van de werkenden in deze sector, terwijl dit percentage landelijk slechts ongeveer 8 bedraagt. Het hoge werkgelegenheidsaandeel in Limburg van de metaal- \& elektrotechnische industrie vindt met name zijn oorsprong in het relatief grote belang van de elektrotechnische en de transportmiddelenindustrie in Limburg. Daarnaast zijn met name de hout- \& bouwmaterialenindustrie en de papierindustrie in Limburg sterk vertegenwoordigd. Het industriële karakter van de werkgelegenheid in Limburg impliceert tevens dat de andere sectoren relatief klein zijn in vergelijking met het landelijke beeld. Dat geldt vooral voor de dienstverlenende sectoren. Terwijl landelijk ruim $40 \%$ van de werkenden een baan heeft in de dienstensectoren, is dit percentage in Limburg slechts ongeveer $35 \%$.

Dit sectorale beeld is ook terug te vinden in de beroepen- en opleidingenstructuur van de Limburgse werkgelegenheid. De relatief sterk vertegenwoordigde beroepsgroepen en opleidingstypen in de Limburgse werkgelegenheid zijn merendeels in de industrie te vinden en hebben vaak een technisch karakter. Bovendien is het gemiddelde kwalificatieniveau van de Limburgse werkgelegenheid relatief laag. De oorzaak hiervan kan voor een belangrijk deel gevonden worden in het feit dat de dienstensector, waar veel hoger opgeleiden werk vinden, in Limburg relatief klein is.

Ook binnen Limburg zijn er duidelijke verschillen in de werkgelegenheidsstructuur. De agrarische sector is in Noord- en Midden-Limburg relatief groot; ruim $8 \%$ van de werkenden in deze regio is in deze sector werkzaam. Dit is niet alleen veel hoger dan in Zuid-Limburg, waar slechts $1 \%$ van de werkenden emplooi vindt in de agrarische sector, maar ook meer dan tweemaal zo hoog als het landelijk gemiddelde van $4 \%$. Ook het industriële karakter van de werkgelegenheid in Limburg komt in Noord- en Midden-Limburg veel sterker tot uiting dan in Zuid-Limburg. In Noord- en Midden-Limburg is meer dan een kwart van de werkenden in de industrie werkzaam; in Zuid-Limburg is dit ruim $20 \%$. Bovendien zijn er duidelijke verschillen in de samenstelling van de industriële werkgelegenheid. De chemische sector is in Zuid-Limburg relatief groot, terwijl in Noord- en Midden-Limburg de metaal- \& elektrotechnische industrie het leeuwendeel (bijna tweederde) van de industriële werkgelegenheid voor zijn rekening neemt. Gezien het grote aandeel van de agrarische sector en de industrie, is het niet verrassend dat de dienstensectoren en de overheidssector in Noord- en Midden-Limburg kleiner zijn dan in Zuid-Limburg. Het relatief kleine 
werkgelegenheidsaandeel van de dienstensectoren in Limburg vergeleken met de rest van Nederland wordt dan ook voor een belangrijk deel veroorzaakt door de afwijkende werkgelegenheidsstructuur in Noord- en Midden-Limburg.

De grootste discrepanties tussen vraag en aanbod doen zich momenteel voor in de metaal\& elektrotechnische industrie en de commerciële diensten. In de metaal- \& elektrotechnische industrie is er sprake van een grote arbeidsmarktkrapte en een zeer hoog percentage moeilijk vervulbare vacatures. Ook het bank- \& verzekeringswezen en de overige tertiaire diensten worden geconfronteerd met een zeer grote arbeidsmarktkrapte. Bovendien is de vacaturegraad in deze sectoren hoog. Specifieke problemen doen zich voor in de chemie, waar weliswaar sprake is van een grote arbeidsmarktkrapte, maar waar de vacaturegraad en het percentage moeilijk vervulbare vacatures toch relatief laag zijn. Blijkbaar is de aanzuigende werking van de grote bedrijven in de chemische sector zo groot dat het (schaarse) arbeidsaanbod op de verschillende voor de sector relevante arbeidsmarktsegmenten vaak voor een functie in de chemie kiest. Ook de bouw kent een specifiek aansluitingsprobleem. Een in het algemeen geringe krapte op de arbeidsmarktsegmenten waarop deze sector haar personeel werft, gaat gepaard met een hoog percentage moeilijk vervulbare vacatures. Ondanks het feit dat er, gemiddeld genomen, volgens Arbeidsvoorziening Limburg voldoende direct inzetbare werkzoekenden beschikbaar zijn, is er, gezien het hoge percentage moeilijk vervulbare vacatures in de bouwsector, toch sprake van rekruteringsproblemen. Deze op het eerste gezicht paradoxale situatie kan verschillende oorzaken hebben. Ten eerste kunnen de rekruteringsproblemen in zeer specifieke segmenten optreden. Ten tweede kan de oorzaak gelegen zijn in het feit dat de vacatures in de bouw onvoldoende aantrekkelijk gevonden worden door de werkzoekenden. Ten derde kan er sprake zijn van kwalitatieve aansluitingsproblemen. Enerzijds blijkt er vooral behoefte te zijn aan schoolverlaters, die schaars zijn; anderzijds wordt het opleidingsniveau van de werkzoekenden in de bouw vaak als te laag beschouwd.

Ondanks het tekort aan arbeidskrachten op specifieke segmenten op de arbeidsmarkt, is het werkloosheidspercentage nog steeds aanzienlijk. Momenteel is bijna $7 \%$ van de beroepsbevolking werkloos, hetgeen vergelijkbaar is met het landelijk percentage. Onder invloed van de toenemende krapte op de arbeidsmarkt de komende jaren zal de werkloosheid naar verwachting afnemen tot bijna $5 \%$ in 2002. Aangezien de werkloosheidsdaling in Limburg naar verwachting sneller zal verlopen dan in de rest van het land, zal het werkloosheidspercentage naar verwachting in 2002 ongeveer 1\% lager zijn het landelijk percentage.

\section{Toekomstige knelpunten in de personeelsvoorziening}

De economische groei die Limburg de laatste jaren doormaakt, zal zich naar verwachting de komende jaren voortzetten. Deze gunstige ontwikkelingen resulteren in een werkgelegenheidsgroei in Limburg van $1,7 \%$ in 1998. Op de middellange termijn wordt een iets lagere groei verwacht. Gemiddeld zal de Limburgse werkgelegenheid naar verwachting tot het jaar 
2002 met jaarlijks 1,6\% groeien. Deze werkgelegenheidstoename is iets lager dan de verwachte gemiddelde groei van de werkgelegenheid in Nederland.

Een belangrijke ontwikkeling op de Limburgse arbeidsmarkt is ook de zogenaamde vergrijzing en ontgroening van de beroepsbevolking. Het werkgelegenheidsaandeel van de ouderen neemt de komende jaren toe. Dit heeft twee oorzaken: enerzijds neemt het aantal werkenden boven de 50 jaar toe, anderzijds neemt de instroom van jongeren op de arbeidsmarkt steeds verder af. In Limburg is dit verschijnsel beter merkbaar dan in de rest van Nederland. De snelle vergrijzing komt tot uiting in de verwachte arbeidsmarktuitstroom van werkenden. In Limburg zal de uitstroom de komende jaren beduidend hoger zijn dan in de rest van Nederland. Naast de vergrijzing van de beroepsbevolking ligt ook het industriële karakter van de werkgelegenheid ten grondslag aan het hoge regionale uitstroompercentage. In de industrie is er vaker sprake van zwaar lichamelijk werk en andere belastende arbeidsomstandigheden, waardoor de arbeidsmarktuitstroom wordt versneld. Hoewel niet alle openvallende banen automatisch opgevuld zullen worden door nieuwkomers, wordt verwacht dat, evenals de arbeidsmarktuitstroom, ook de vervangingsvraag in Limburg groter zal zijn dan in de rest van Nederland.

Aan de aanbodzijde van de arbeidsmarkt eist de ontgroening zijn tol. Het aantal jongeren daalt. Hierdoor neemt het aantal onderwijsvolgenden af. Daarnaast volgen jongeren steeds langer een voltijdsopleiding, waardoor hun intrede op de arbeidsmarkt wordt uitgesteld. Het aantal schoolverlaters dat instroomt op de arbeidsmarkt zal als gevolg van deze ontwikkelingen naar verwachting de komende jaren verder dalen.

Momenteel worden reeds op specifieke segmenten op de arbeidsmarkt knelpunten in de personeelsvoorziening ervaren. Door aan de ene kant het aantrekken van de werkgelegenheidsgroei en de toename van de arbeidsmarktuitstroom vanwege de vergrijzing van de beroepsbevolking en aan de andere kant de teruglopende arbeidsmarktinstroom van schoolverlaters zullen de knelpunten in de personeelsvoorziening de komende jaren aanzienlijk toenemen. In 1998 wordt voor maar liefst ruim $50 \%$ van de onderscheiden opleidingstypen op lagere en middelbare grote knelpunten verwacht. Dit geldt met name voor de opleidingen op MBO/Leerlingwezen-niveau, waar er voor bijna $80 \%$ van de onderscheiden opleidingstypen sprake zal zijn van een tekort aan direct inzetbare werkzoekenden. De 'upgrading' van de opleidingseisen in verschillende beroepsgroepen speelt hierbij een belangrijke rol. De verkrapping van de arbeidsmarkt zal naar verwachting na 1998 in snel tempo toenemen. In 2002 zal naar verwachting voor $70 \%$ van de onderscheiden opleidingstypen sprake zijn van grote tot zeer grote knelpunten. De problemen spitsen zich opnieuw toe op het $\mathrm{MBO} /$ Leerlingwezen-niveau, waar voor maar liefst $90 \%$ van de opleidingstypen grote tot zeer grote knelpunten in de personeelsvoorziening worden verwacht. Bovendien zullen voor een groot aantal opleidingstypen, met name op MBO/Leerlingwezen-niveau, de knelpunten in 1998 als 'groot' en in 2002 als 'zeer groot' getypeerd kunnen worden. Deze toenemende krapte betekent dat de komende jaren vrijwel alle bedrijfssectoren met grote knelpunten in de 
personeelsvoorziening zullen worden geconfronteerd.

De meest nijpende knelpunten worden, zoals gezegd, verwacht op MBO/Leerlingwezenniveau. Het gaat hierbij vooral om de technische richtingen, zoals vervoer, procestechniek, automatisering, bouw en motorvoertuigentechniek en de richtingen horeca, bedrijfskunde, en verpleging. Een gedetailleerd overzicht van de verwachte knelpunten in de personeelsvoorziening naar opleidingstype is te vinden in de tabellen 5.8 en 6.8 van de Statistische Bijlage.

\section{Toekomstige arbeidsmarktperspectieven voor schoolverlaters}

De toenemende krapte leidt ertoe dat de toekomstige perspectieven voor schoolverlaters op de Limburgse arbeidsmarkt over het algemeen goed tot zeer goed zijn. Bovendien zullen deze perspectieven de komende jaren voor veel opleidingen steeds verder verbeteren. Desondanks zullen voor de schoolverlaters van een aantal opleidingstypen de perspectieven naar verwachting matig tot slecht zijn. Dit geldt met name voor de schoolverlaters van het Basisonderwijs, het HAVO/VWO, de VBO-opleidingen administratie, handel \& textiel, landbouw \& natuurlijke omgeving, grafische techniek en horeca \& levensmiddelentechniek en de opleidingen beweging \& therapie en toerisme \& recreatie op MBO-niveau. Een gedetailleerd overzicht van de verwachte arbeidsmarktperspectieven naar opleidingstype op VBO- en MBO/Leerlingwezen-niveau is te vinden in de tabellen 5.8 en 6.8 van de Statistische Bijlage.

Hoger opgeleiden kennen een veel grotere (geografische) mobiliteit op de arbeidsmarkt dan de lager en middelbaar opgeleiden. Dit heeft als gevolg dat de regionale verschillen in de arbeidsmarktsituatie doorgaans geringer zijn dan bij de middelbare en lagere opleidingen. Dit heeft als gevolg dat de landelijke indicator voor het arbeidsmarktperspectief in feite een goede maatstaf vormt voor de toekomstige situatie op de arbeidsmarkt voor hoger opgeleiden in Limburg.

Het landelijk arbeidsmarktperspectief voor de afgestudeerden van HBO- en WO-opleidingen is over het algemeen goed tot zeer goed. Over het algemeen zal de uitbreidingsvraag naar hoger opgeleiden in Limburg echter wat lager zijn dan in de rest van het land. Het naar verwachting wat tragere upgradingsproces van de opleidingenstructuur van de werkgelegenheid in Limburg ligt hieraan ten grondslag. Het industriële karakter van de werkgelegenheid speelt hierbij een belangrijke rol. Het werkgelegenheidsperspectief voor nieuwkomers met een hogere opleiding zal daarom iets minder goed zijn in Limburg dan in de rest van het land. De belangrijkste uitzondering op dit beeld vormt de universitaire studierichting wiskunde \& natuurwetenschappen. Het percentage baanopeningen zal voor dit opleidingstype naar verwachting groter zijn dan in de rest van het land. Het perspectief voor dit opleidingstype zal daarom in Limburg nog beter zijn dan in de rest van het land. Dit beeld zal worden versterkt door het feit dat de arbeidsmarktinstroom van afstudeerders met deze opleidingsachtergrond op de Limburgse arbeidsmarkt zeer gering is vanwege het vrijwel 
ontbreken van universitaire opleidingen in deze studierichting in de provincie Limburg.

\section{Uitgelicht: knelpunten in de handel}

In de handel worden thans met name in de volgende beroepen knelpunten ervaren: de elementaire beroepen (algemeen medewerker intern en extern), de chauffeurs, de verkopers (zowel algemeen als vakspecifiek), de hoofden technische dienst, de monteurs (met name elektromonteurs), de meet- en regeltechnici, de middelbare administratief-commerciële beroepen en de drogisten.

Vooral de grote vraag naar jongeren leidt, als gevolg van de ontgroening van de beroepsbevolking, in de handel tot steeds grotere knelpunten in de personeelsvoorziening. Daarnaast worden door werkgevers steeds hogere eisen gesteld; eisen waaraan het aanbod op dit moment niet kan voldoen. Het gaat hierbij om de bereidheid om te blijven leren, een positieve werkhouding, communicatieve vaardigheden en een klantgerichte instelling. In het bijzonder wordt in de handel gewezen op de gevraagde combinatie van commerciële vaardigheden en specialistische kennis die voor verkoopadviserende werkzaamheden vereist is. Werkgevers wijzen daarnaast vooral op een gebrek aan werkervaring bij de werkzoekenden. Een typisch probleem in de handel is het toenemend belang van relatief grote part-time banen, mede als gevolg van de verruimde openingstijden van winkels. Werkzoekenden zijn daarentegen vaak op zoek naar een full-time baan. Ten slotte kampt de handel op de arbeidsmarkt met een imago-probleem, wat vooral veroorzaakt wordt door de relatief slechte arbeidsvoorwaarden en de geringe investeringen in aanvullende scholing.

In 1998 worden voor de belangrijkste opleidingstypen in de handel relatief beperkte knelpunten in de personeelsvoorziening verwacht. De knelpunten zullen zich concentreren op MBO/Leerlingwezen-niveau. Op de middellange termijn zullen de knelpunten in de handel naar verwachting echter aanzienlijk toenemen. Voor de handel belangrijke opleidingstypen $\mathrm{MBO} / \mathrm{LLW}$ handel en MBO/LLW administratie worden zelfs grote knelpunten verwacht. Ook voor MAVO'ers zullen er enige knelpunten in de personeelsvoorziening optreden.

Bij het zoeken naar mogelijke oplossingen dient rekening te worden gehouden met het specifieke karakter van deze sector. De gemiddeld genomen kleinschaligheid van de bedrijven in met name de detailhandel leidt ertoe dat bedrijven moeilijk via interne scholing en doorstroming rekruteringsproblemen kunnen bestrijden. Er kan vooral gedacht worden aan:

-het meer richten van het onderwijs op communicatieve vaardigheden en werkhouding ;

-het minder star hanteren van functie-eisen door bedrijven;

-het accent meer leggen op vraaggerichte scholing door Arbeidsvoorziening;

-het creëren van banenpools.

Uitgelicht: knelpunten in de industrie 
In de industrie worden thans met name in de volgende beroepen knelpunten ervaren: de productiemedewerkers, de operators, de bouwvakkers, de procesoperators, de monteurs (op lager en middelbaar niveau), de bankwerkers en lassers, de documentalisten, de drukkers, de meet- en regeltechnici, de informatici met management vaardigheden en de gekwalificeerde secretaresses.

Vooral de gebrekkige aansluiting tussen onderwijs en arbeidsmarkt blijkt in de industrie tot knelpunten te leiden. $\mathrm{Er}$ is een tekort aan gekwalificeerde vaklieden; het opleidingsniveau van de werkzoekenden wordt als te laag ervaren. Bovendien is er sprake van een minder goede aansluiting tussen theorie en praktijk. Specifiek kan hierbij gewezen worden op het feit dat werkgevers steeds vaker een Leerlingwezen-opleiding als minimum-opleidingseis stellen bij het rekruteren van nieuw personeel. Aan laag gekwalificeerde banen zoals bedieningsfuncties worden, als gevolg van de toenemende automatisering, bovendien steeds hogere vakinhoudelijke eisen gesteld. Ook tekortschietende vaardigheden, zoals de wil om te blijven leren, een positieve werkhouding, communicatieve vaardigheden en een klantgerichte instelling worden als belangrijke knelpunten gezien. Met name in de wat hogere functies in (middel)grote bedrijven worden deze niet-vakinhoudelijke vaardigheden steeds belangrijker. Tevens wordt een toenemend beroep gedaan op de flexibiliteit van werknemers, wat de intredebereidheid van werkzoekenden negatief beïnvloedt. Ten slotte speelt ook het slechte imago van het werken in de industrie een rol.

In 1998 wordt er voor de industrie een sterke toename van de knelpunten in de personeelsvoorziening verwacht. Als gevolg van het 'upgradingsproces' in de verschillende beroepsgroepen - het steeds hogere eisen stellen bij de rekrutering van nieuw personeel concentreren deze knelpunten zich op MBO/Leerlingwezen-niveau. Op de middellange termijn zullen deze knelpunten naar verwachting alleen nog maar toenemen.

Bij mogelijke oplossingen voor de toenemende krapte kan, voor wat betreft de (middel)lange termijn, gedacht worden aan:

-het stimuleren van de leerlingeninstroom in het technisch onderwijs;

-het bevorderen van de aansluiting tussen onderwijs en arbeidsmarkt;

-het bewuster voeren van een actief personeelsbeleid.

\section{Scholingsbeleid}

De aansluitingsproblematiek tussen vraag en aanbod is in belangrijke mate een scholingsen trainingsvraagstuk. Bij- en omscholing van werkzoekenden kan daarom een effectief middel zijn om discrepanties te verminderen. Door middel van bijscholing kunnen aansluitingsproblemen tussen de vaardigheden waarover de werkzoekenden in een bepaald arbeidsmarktsegment beschikken en de in dat segment gevraagde vaardigheden verminderd worden. Met andere woorden: bijscholing kan een effectief middel zijn om kwalitatieve aans/uitingsproblemen in een bepaald arbeidsmarktsegment het hoofd te bieden. Door middel van omscholing kunnen knelpunten op de arbeidsmarkt, die hun 
oorsprong vinden in het feit dat in een specifiek arbeidsmarktsegment er geen werkzoekenden beschikbaar zijn om aan de vraag te voldoen, verminderd worden. Omscholing van werkzoekenden waarvoor er sprake is van een overschot, kan dus een effectief middel zijn om kwantitatieve aansluitingsproblemen op andere arbeidsmarktsegmenten te verminderen. Aangezien de aansluitingsproblemen, naast vakinhoudelijke vaardigheden, ook betrekking hebben op de werkhouding, communicatieve vaardigheden, de wil om te blijven leren en een klantvriendelijke instelling, e.d. dient het bijscholingsbeleid ook op deze aspecten gericht te worden.

De scholingsbehoefte zal zich in 1998 naar verwachting geheel concentreren op het vergroten van het direct inzetbare arbeidsaanbod op MBO/Leerlingwezen-niveau. Belangrijke beroepsgroepen waar door middel van bij- en omscholing het tekort aan direct inzetbare werkzoekenden kan worden verminderd zijn: de productiemedewerkers, de vakkenvullers, de procesoperators, de bankwerkers en lassers, de bouwvakkers, de installateurs, de (elektro)monteurs, de programmeurs, de agrarisch arbeiders, de beveiligingsemployés, de commercieel employés, de verkopers, de secretaresses, de chauffeurs, de verplegenden en de horeca-functies.

\section{Onderwijsbeleid}

Vanuit het oogpunt van de zogenaamde macrodoelmatigheid van het onderwijs is het wenselijk de instroom van leerlingen in opleidingen met goede of zeer goede arbeidsmarktperspectieven te bevorderen. Het zonder meer vergroten van het onderwijsaanbod zal echter niet altijd de gewenste effecten sorteren. Een vergroting van de opleidingscapaciteit garandeert immers niet dat deze capaciteit ook benut zal worden. Een verruimde geografische spreiding of de introductie van een opleidingsvariant die op dat moment nog niet wordt aangeboden, zal doorgaans wel de leerlingeninstroom voor het betreffende opleidingstype vergroten, doordat mobiliteitsdrempels worden weggenomen of omdat beter ingespeeld kan worden op de interesse of capaciteiten van leerlingen. Een vraag die zich voordoet bij een dergelijke uitbreiding van het onderwijsaanbod is echter welke leerlingen hiermee worden aangetrokken. Nieuw aanbod van opleidingen zal met name baat hebben wanneer er leerlingen worden aangetrokken die anders een opleiding zouden kiezen met duidelijk slechtere perspectieven.

Naast het arbeidsmarktperspectief, dat gebaseerd is op de verwachte ontwikkelingen in vraag en aanbod, kan het onderwijsbeleid ook de structurele positie van opleidingen als richtlijn nemen. Een tweetal risico-indicatoren is op dit punt van belang: de conjunctuurgevoeligheid van de werkgelegenheid en de uitwijkmogelijkheden naar verschillende beroepsgroepen. Zo zijn er bepaalde opleidingen die een hoge mate van conjunctuurgevoeligheid combineren met beperkte uitwijkmogelijkheden. Veranderingen in het onderwijs, waardoor de opleiding wordt verbreed en daardoor toegang verschaft tot een breder beroependomein, kan deze kwetsbaarheid verminderen. Omgekeerd kunnen ontwikkelingen aan de vraagkant van de arbeidsmarkt leiden tot een behoefte aan personeel 
met zeer specifieke vaardigheden. Hierdoor kan het wenselijk zijn een meer specialistische opleiding te starten. Hierbij dient altijd wel overwogen te worden in hoeverre de vraag naar deze vakspecialisten stabiel is, omdat de voordelen van het specialisme op moeten wegen tegen het arbeidsmarktrisico dat een dergelijke specialisatie met zich meebrengt.

De macrodoelmatigheid van het beroepsonderwijs is het meest gebaat bij een adequaat aanbod van leerwegen die VBO schoolverlaters in staat stellen een kwalificatie op $\mathrm{MBO} /$ Leerlingwezen-niveau te behalen. Dit geldt het sterkst voor de vervoers-, motorvoertuigentechniek-, grafische techniek-, administratie-, handel- en horeca-opleidingen en vanzelfsprekend ook voor de opleidingen die ongeschoolden met slechts Basisonderwijs en MAVO'ers en HAVO-VWO'ers in staat stellen met succes een beroepsopleiding te volgen met goede arbeidsmarktperspectieven en geringe arbeidsmarktrisico's. Ook opleidingen die een verschuiving van de schoolkeuze van het te populaire opleidingstype MBO/LLW toerisme en recreatie naar administratief-economische opleidingen met een betere arbeidsmarktpositie bewerkstelligen, kunnen een belangrijke bijdrage leveren aan het vergroten van de macrodoelmatigheid van het onderwijs in Limburg. 


\section{$1.1 \quad$ Inleiding}

In dit hoofdstuk zal een globale schets worden gegeven van de huidige en toekomstige ontwikkelingen op de Limburgse arbeidsmarkt. Eerst wordt een beeld geschetst van de Limburgse arbeidsmarkt op macro-niveau. Hierbij zal ook aandacht worden geschonken aan de achterliggende factoren die invloed hebben op de Limburgse arbeidsmarktontwikkelingen. Daarna worden de ontwikkelingen verbijzonderd naar bedrijfssector, beroepssector en opleidingsniveau. Hierbij zal, waar mogelijk, een vergelijking worden gemaakt met de landelijke ontwikkelingen. Overigens worden de in dit hoofdstuk op een hoog aggregatieniveau geschetste ontwikkelingen in latere hoofdstukken nader toegelicht en verder verbijzonderd.

\subsection{De verwachte arbeidsmarktontwikkeling}

De economische groei die Limburg de laatste jaren doormaakt zal zich naar verwachting de komende jaren doorzetten. Deze gunstige verwachtingen resulteren, zoals tabel 1.1 laat zien, in een werkgelegenheidsgroei in Limburg van 1,7\% in 1998. Dit is een groei van bijna 7.500 banen. Op de middellange termijn wordt een iets lagere groei verwacht. Gemiddeld zal de Limburgse werkgelegenheid naar verwachting tot het jaar 2002 met jaarlijks 1,6\% groeien. Een vergelijking met Nederland als geheel laat zien dat de werkgelegenheidstoename in Limburg de komende jaren naar verwachting jaarlijks 0,1 procent lager zal zijn dan de gemiddelde groei van de landelijke werkgelegenheid².

Een belangrijke ontwikkeling op de Limburgse arbeidsmarkt is de zogenaamde vergrijzing en ontgroening van de beroepsbevolking. In een eerdere studie van het ETIL werd hier reeds op gewezen ${ }^{3}$. Het aandeel van de ouderen in de werkgelegenheid neemt de komende jaren toe. Dit heeft twee oorzaken: enerzijds neemt het aantal werkenden boven de 50 jaar toe, anderzijds neemt de instroom van jongeren op de arbeidsmarkt steeds verder af. In Limburg is dit verschijnsel beter merkbaar dan in de rest van Nederland. Terwijl in Nederland 15,0\% van de werkzame beroepsbevolking ouder is dan 50 jaar, bedraagt dit percentage in Limburg $15,4 \%{ }^{4}$. Het percentage werkenden dat jonger is dan 30 jaar is in Limburg daarentegen lager dan in de rest van Nederland. In Limburg bedraagt dit percentage $26,2 \%$, terwijl het landelijk percentage 28,6 bedraagt. Limburg ontgroent en vergrijst derhalve sneller dan de rest van Nederland.

2. Zie TNO/INRO en NEI, Regionale Arbeidsmarktschets, Delft, 1997.

3. ETIL, Bevolking Limburg 1960-1995-2020, 1996, Maastricht.

4. Tenzij anders vermeld, betreffen de actuele cijfers in dit hoofdstuk gemiddelden over 1995 en 1996. 
De snelle vergrijzing komt ook tot uiting in de verwachte arbeidsmarktuitstroom van werkenden. Verwacht wordt dat in 1998 4,7\% van de Limburgse werkzame beroepsbevolking vanwege arbeidsongeschiktheid, pensionering en vervroegde uittreding de arbeidsmarkt zal verlaten. Hoewel de uitstroom tot 2002 naar verwachting wat lager zal zijn (jaarlijks gemiddeld $3,9 \%$ ), zal de uitstroom beduidend hoger zijn dan in de rest van Nederland.

Tabel 1.1

Verwachte arbeidsmarktontwikkeling in 1998 en in de periode 1997-2002 (gemiddelde jaarlijkse percentages)

\begin{tabular}{|c|c|c|c|}
\hline & $\begin{array}{c}1998 \\
\text { Limburg } \\
\%\end{array}$ & $\begin{array}{c}1997-2002 \\
\text { Limburg } \\
\%\end{array}$ & $\begin{array}{c}1997-2002 \\
\text { Nederland } \\
\%\end{array}$ \\
\hline Werkgelegenheidstoename & 1,7 & 1,6 & 1,7 \\
\hline Arbeidsmarktuitstroom & 4,7 & 3,9 & 3,3 \\
\hline Baanopeningen & 6,4 & 5,5 & 5,0 \\
\hline Instroom schoolverlaters ${ }^{5}$ & 3,1 & 2,5 & 4,2 \\
\hline
\end{tabular}

Bron: CPB/TNO/Inro/ROA

In Nederland wordt voor de komende jaren namelijk een jaarlijkse uitstroom van 3,3\% verwacht. Naast de snelle ontgroening en vergrijzing van de beroepsbevolking, wordt het relatief hoge regionale uitstroompercentage ook door het industriële karakter van de werkgelegenheid veroorzaakt. In de industrie is vaker sprake van zwaar lichamelijk werk en andere belastende arbeidsomstandigheden, waardoor de uitstroom van de arbeidsmarkt wordt versneld. Hoewel niet alle openvallende banen automatisch opgevuld zullen worden door nieuwkomers, wordt verwacht dat, evenals de arbeidsmarktuitstroom, ook de vervangingsvraag in Limburg groter zal zijn dan in de rest van Nederland.

De werkgelegenheidstoename en de arbeidsmarktuitstroom resulteren in 1998 is een aantal baanopeningen van maar liefst $6,4 \%$ van het aantal werkenden op de Limburgse arbeidsmarkt. Dit betekent dat er naar verwachting ongeveer 27.000 baanopeningen voor nieuwkomers op de arbeidsmarkt zullen zijn. Het percentage baanopeningen zal tot 2002 enigszins dalen tot gemiddeld 5,5\% per jaar, wat echter duidelijk hoger is dan het landelijk percentage van gemiddeld $5 \%$ per jaar. Dit verschil kan toegeschreven worden aan de hogere arbeidsmarktuitstroom in Limburg in vergelijking met de uitstroom in de rest van Nederland.

5. Als gevolg van het gebruik van verschillende methodieken zijn de aanbodcijfers voor Limburg en Nederland niet geheel vergelijkbaar. 
Aan de aanbodzijde van de arbeidsmarkt eist de ontgroening zijn tol. Het aantal jongeren daalt. Hierdoor neemt het aantal onderwijsvolgenden af. Daarnaast volgen jongeren steeds langer een voltijdsopleiding, waardoor hun intrede op de arbeidsmarkt wordt uitgesteld. Het aantal schoolverlaters dat instroomt op de arbeidsmarkt zal als gevolg van deze ontwikkelingen naar verwachting de komende jaren verder dalen. In 1998 wordt een arbeidsmarktinstroom van 3,1\% van het aantal werkenden verwacht; tot 2002 zal dit percentage naar verwachting verder dalen tot gemiddeld $2,5 \%$ per jaar.

Enerzijds zal dus het aantal baanopeningen voor nieuwkomers stijgen als gevolg van de economische groei in combinatie met de demografische ontwikkelingen. Anderzijds zal de instroom van nieuwkomers op de arbeidsmarkt dalen, waardoor schoolverlaters gewilde kandidaten worden voor de werkgevers. Per saldo resulteert dit in gunstige perspectieven voor nieuwkomers op de arbeidsmarkt. De keerzijde is dat op macro-niveau op de Limburgse arbeidsmarkt een tekort aan direct inzetbare arbeidskrachten ontstaat. Dit zal leiden tot grote knelpunten in de personeelsvoorziening. Werkgevers kunnen op deze ontwikkeling inspelen door de uitstroom van oudere werknemers af te remmen of door arbeidskrachten aan te trekken met een grotere afstand tot de arbeidsmarkt. Ook het verhogen van de participatiegraad van de potentiële beroepsbevolking zou een belangrijke rol kunnen spelen bij het voorkomen van de verwachte knelpunten in de personeelsvoorziening. Het spreekt voor zich dat dit noodzaakt tot aanzienlijke bij- en omscholingsprogramma's. In hoofdstuk 6 van dit rapport wordt een indicatie gegeven van de gewenste omvang van de scholingsinspanningen om in 1998 te anticiperen op de verwachte knelpunten in de personeelsvoorziening op de Limburgse arbeidsmarkt.

Naast de bovengenoemde instrumenten, laten recente ontwikkelingen op de Limburgse arbeidsmarkt zien dat bedrijven ook anderszins inspelen op de knelpunten in de personeelsvoorziening op de Limburgse arbeidsmarkt $t^{6}$. De verdergaande internationalisering en de daarmee gepaard gaande concurrentie uit het buitenland zal in toenemende mate leiden tot een streven naar een efficiënte werkwijze en naar de levering van die producten en diensten die de grootste toegevoegde waarde opleveren. De vraag naar nieuwkomers zou daardoor kunnen worden afgeremd. Daarnaast komt, bij toenemende knelpunten, verplaatsing van (bepaalde) bedrijfsactiviteiten naar het buitenland steeds meer in het vizier. Daarnaast kan het werven van personeel in het (aangrenzende) buitenland soelaas bieden. Met name Belgisch personeel is daarbij, gezien de geringe cultuurverschillen en de beperkte taalproblemen, aantrekkelijk. Daarna komt Engeland en vervolgens Duitsland in beeld. Gezien het grotere belang van taal en cultuur in de dienstverlenende bedrijfssectoren, zijn de wervingsmogelijkheden in het buitenland voor deze sectoren echter doorgaans beperkter dan voor de industriële sectoren.

6. Zie Van Camp, H., Kwalitatieve informatie over de Limburgse arbeidsmarkt: enkele aspecten op de middellange termijn, werkdocument IV, ETIL, Maastricht, 1997d. 
De toenemende knelpunten in de personeelsvoorziening zullen ook hun weerslag hebben op de omvang van de werkloosheid in Limburg. TNO/Inro en NEI verwachten een daling van de werkloosheid in Limburg van $6,7 \%$ naar $4,6 \%$ van de beroepsbevolking, zoals tabel 1.2 laat zien. Absoluut gezien betekent dit een daling van ruim 9.000 personen $^{7}$. Opvallend daarbij is dat de daling van de werkloosheid in Limburg naar verwachting sneller zal verlopen dan in de rest van het land. Terwijl de werkloosheid in Limburg in 1997 slechts $0,2 \%$ lager is dan het landelijk percentage; in 2002 zal dit verschil naar verwachting gestegen zijn tot bijna $1 \%$.

Tabel 1.2

Verwachte werkloosheidsontwikkeling volgens TNO/Inro en NEI, 1997, 1998 en 2002

\begin{tabular}{lccc}
\hline & $\begin{array}{c}1997 \\
\%\end{array}$ & $\begin{array}{c}1998 \\
\%\end{array}$ & $\begin{array}{c}2002 \\
\%\end{array}$ \\
\hline Limburg & 6,7 & 6,1 & 4,6 \\
Nederland & 6,9 & 6,5 & 5,5 \\
\hline
\end{tabular}

Bron: TNO/Inro/NEI

\subsection{Arbeidsmarktontwikkelingen naar bedrijfssector}

Tabel 1.3 geeft een overzicht van de actuele discrepanties tussen vraag en aanbod op de Limburgse arbeidsmarkt naar bedrijfssector. In deze tabel worden drie indicatoren gepresenteerd die, elk vanuit een verschillende invalshoek, een indicatie geven van de rekruteringsproblemen die werkgevers momenteel op de Limburgse arbeidsmarkt ondervinden. De arbeidsmarktkrapte geeft de verhouding weer tussen het aantal openstaande vacatures en het aantal direct inzetbare werkzoekenden. De vacaturegraad geeft het aantal openstaande vacatures als promillage van de werkgelegenheid weer. Het percentage moeilijk vervulbare vacatures geeft de verhouding aan tussen het aantal vacatures dat langer dan drie maanden openstaat en het totaal aantal openstaande vacatures.

7. Zie TNO/Inro en NEI, Regionale arbeidsmarktschets, Delft, 1997. 
Tabel 1.3

Actuele discrepanties naar bedrijfssector, 1997, Limburg

$\begin{array}{llll}\text { Bedrijfssector } & \begin{array}{l}\text { arbeidsmarkt- } \\ \text { krapte }\end{array} & \begin{array}{l}\text { vacature- } \\ \text { graad }\end{array} & \begin{array}{l}\text { \% langdurig } \\ \text { openstaand }\end{array}\end{array}$

$\begin{array}{llll}\text { Landbouw en visserij } & \text { laag } & \text { gemiddeld } & \text { gemiddeld } \\ \text { Voedings- en genotsmiddelenindustrie } & \text { laag } & \text { gemiddeld } & \text { gemiddeld } \\ \text { Overige industrie } & \text { gemiddeld } & \text { gemiddeld } & \text { gemiddeld } \\ \text { Chemische industrie } & \text { zeer hoog } & \text { laag } & \text { laag } \\ \text { Metaalindustrie } & \text { hoog } & \text { gemiddeld } & \text { zeer hoog } \\ \text { Energie } & \text { gemiddeld } & \text { laag } & \text { gemiddeld } \\ \text { Bouw en onroerend goed } & \text { zeer laag } & \text { gemiddeld } & \text { hoog } \\ \text { Groot- en detailhandel } & \text { gemiddeld } & \text { hoog } & \text { laag } \\ \text { Transport, opslag en communicatie } & \text { laag } & \text { gemiddeld } & \text { gemiddeld } \\ \text { Bank- en verzekeringswezen } & \text { zeer hoog } & \text { hoog } & \text { laag } \\ \text { Andere tertiaire diensten } & \text { zeer hoog } & \text { zeer hoog } & \text { gemiddeld } \\ \text { Kwartaire diensten } & \text { gemiddeld } & \text { laag } & \text { laag } \\ \text { Overheid } & \text { gemiddeld } & \text { gemiddeld } & \text { laag }\end{array}$

Bron: Arbeidsvoorziening/CBS/ROA

Tabel 1.3 geeft aan dat de grootste problemen zich voordoen in de metaalindustrie en de commerciële diensten. In de metaalindustrie is sprake van een grote arbeidsmarktkrapte en een zeer hoog percentage moeilijk vervulbare vacatures. Het bank- en verzekeringswezen en de andere tertiaire diensten worden geconfronteerd met een zeer grote arbeidsmarktkrapte. Bovendien is de vacaturegraad in deze sectoren hoog. Specifieke problemen doen zich voor in de chemie, waar weliswaar sprake is van een grote arbeidsmarktkrapte, maar de vacaturegraad en het percentage moeilijk vervulbare vacatures toch relatief laag zijn. Blijkbaar is de aanzuigende werking van de grote bedrijven in de chemische sector zo groot dat het (schaarse) arbeidsaanbod op de verschillende voor de sector relevante arbeidsmarktsegmenten vaak voor een functie in de chemie kiest. Ook de bouw kent een specifiek aansluitingsprobleem. Een in het algemeen geringe krapte op de arbeidsmarktsegmenten waarop de sector haar personeel werft, gaat gepaard met een hoog percentage moeilijk vervulbare vacatures. Ondanks het feit dat er, gemiddeld genomen, volgens Arbeidsvoorziening Limburg voldoende direct inzetbare werkzoekenden beschikbaar zijn, is er, gezien het hoge percentage moeilijk vervulbare vacatures in de bouwsector toch sprake van rekruteringsproblemen. Deze op het eerste gezicht paradoxale situatie kan verschillende oorzaken hebben. Ten eerste kunnen de rekruteringsproblemen in zeer specifieke segmenten optreden, terwijl er gemiddeld genomen, geen problemen zijn. Ten tweede kan de oorzaak gelegen zijn in het feit dat de bouw niet aantrekkelijk gevonden wordt door de werkzoekenden ${ }^{8}$. Ten derde kan er sprake zijn van kwalitatieve

8. Zie Corten, J.W., 'Dit jaar zijn 35.000 toetreders nodig om arbeidsbestand op peil te houden.', BouwMerk: de bouw in feiten, cijfers en analyses, 22e jaargang, 1997, nr. 2, blz. 8-12. 
aansluitingsproblemen. Enerzijds blijkt er vooral behoefte te zijn aan schoolverlaters, die schaars zijn; anderzijds wordt het opleidingsniveau van de werkzoekenden in de bouw vaak als te laag beschouwd ${ }^{9}$.

Tabel 1.4 geeft aan dat de gunstige ontwikkeling van de werkgelegenheid, zoals geschetst in tabel 1.1, zich niet in alle bedrijfssectoren manifesteert. Er is in Limburg globaal genomen sprake van een verschuiving van de werkgelegenheid van de industrie naar de commerciële dienstverlening ${ }^{10}$. De grootste groei wordt verwacht in de metaalindustrie en de commerciële diensten. Dit geldt zowel voor 1998 als voor de periode 1997-2002. In beide sectoren neemt de groei van de werkgelegenheid echter naar verwachting wel af in de jaren na 1998. De groei in de andere tertiaire diensten zal in Limburg overigens duidelijk lager zijn dan in de rest van het land. De grote groei van de werkgelegenheid in deze sector wordt in belangrijke mate veroorzaakt door het feit dat de uitzendbranche en de detacheringsbedrijven deel uitmaken van deze sector. Naast de toenemende uitbesteding van met name facilitaire dienstenactiviteiten door bedrijven vormt de flexibilisering van de arbeidsmarkt een structurele factor achter de toenemende werkgelegenheid in deze sector. Een aanhoudende economische groei zal overigens naar verwachting leiden tot een afname van de groei van de uitzendbranche. Aanvankelijk wordt een economische opleving opgevangen door het inhuren van uitzendkrachten. Wanneer de economische groei echter aanhoudt, gaan steeds meer bedrijven ertoe over deze uitzendkrachten in eigen dienst te nemen. Deze ontwikkeling ten gevolg van de verder aantrekkende conjunctuur biedt aldus waarschijnlijk een tegenwicht tegen het effect van de structurele toename van het flexibel werken. Hoewel er sprake is van een verschuiving van de werkgelegenheid van de industrie naar de commerciële dienstverlening, blijft de groei van het bank- en verzekeringswezen duidelijk achter. De verdergaande automatisering speelt hierbij een belangrijke rol ${ }^{11}$.

9. Corten, 1997, op. cit.

10. Zie Van Camp, H., 1997d, op. cit.

11. Zie Van Camp, H., 1997d, op. cit. 
Tabel 1.4

Ontwikkeling aantal werkenden per bedrijfssector in 1998 en de periode 1997-2002 (gemiddelde jaarlijkse percentages)

\begin{tabular}{lllll}
\hline Bedrifssector & & & & \\
& $\begin{array}{l}\text { aantal werkenden } \\
\text { Limburg } \\
1995-1996\end{array}$ & $\begin{array}{l}\text { Limburg } \\
\text { 1998 }\end{array}$ & $\begin{array}{l}\text { Limburg } \\
1997-2002 \\
\%\end{array}$ & $\begin{array}{l}\text { Nederland } \\
1997-2002 \\
\%\end{array}$ \\
& & & & \\
& & & & \\
& 17.500 & 1,1 & 1,1 & $-1,0$ \\
Landbouw en visserij & 10.500 & 0,0 & 1,2 & 0,4 \\
Voedings- en genotsmiddelenindustrie & 21.500 & 1,5 & 1,1 & 0,9 \\
Overige industrie & 15.500 & 1,7 & 1,7 & 1,7 \\
Chemische industrie & 59.000 & 3,3 & 2,8 & 1,8 \\
Metaalindustrie & 5.000 & 0,0 & 1,3 & $-0,1$ \\
Energie & 28.500 & $-0,4$ & $-1,0$ & 0,8 \\
Bouw en onroerend goed & 54.000 & 2,7 & 2,6 & 2,2 \\
Groot- en detailhandel & 23.500 & 0,9 & 0,6 & 1,5 \\
Transport, opslag en communicatie & 12.000 & $-0,9$ & 0,8 & 0,4 \\
Bank- en verzekeringswezen & 55.000 & 2,6 & 2,2 & 3,6 \\
Andere tertiaire diensten & 65.000 & 1,8 & 1,6 & 1,7 \\
Kwartaire diensten & 58.500 & $-0,2$ & 0,6 & 0,3 \\
Overheid & & & & \\
Totaal (inclusief sector onbekend) & 434.500 & & & \\
& & &
\end{tabular}

Bron: CBS/CPB/TNO/Inro/ROA

In de bouw wordt een daling van de werkgelegenheid verwacht, mede als gevolg van de demografische ontwikkelingen. Bij de overheid wordt, na een aanvankelijke krimp van de werkgelegenheid op de korte termijn, op de wat langere termijn weer groei verwacht. Een vergelijking met het landelijke beeld laat twee opvallende verschillen zien. Naast de genoemde werkgelegenheidsdaling in de bouwsector is dit de verwachte groei in de landbouwsector. Opgemerkt dient echter te worden dat hierbij geen rekening is gehouden met de gevolgen van de varkenspest. Daarnaast zal de werkgelegenheidsontwikkeling in de industriële sectoren naar verwachting in Limburg relatief gunstig zijn vergeleken met de rest van Nederland. De kansen voor Limburg liggen hierbij vooral bij de bovenregionaal stuwende bedrijven; deze kunnen bijvoorbeeld een Noordwest-Europese afzetmarkt hebben ${ }^{12}$.

\subsection{Werkgelegenheidsontwikkeling naar beroepssector}

Bij de ontwikkelingen in de werkgelegenheid naar beroep spelen, behalve de veranderingen in de werkgelegenheidsstructuur naar bedrijfssector, ook de verschuivingen in de beroepenstructuur binnen bedrijfssectoren een rol. Tabel 1.5 laat zien dat voor alle beroepssectoren, met uitzondering van de openbare orde en veiligheidsberoepen de

12. Zie Van Camp, H., 1997d, op. cit. 
komende vijf jaar een groei in de werkgelegenheid wordt verwacht. Met uitzondering van de pedagogische beroepen en de openbare orde en veiligheidsberoepen laat een vergelijking tussen de verwachte groei in 1998 en de groei in de periode 1997-2002 zien dat de groei zal afzwakken.

Voor de transportberoepen, de economisch-administratieve beroepen, de sociaal-culturele beroepen en de informaticaberoepen wordt de sterkste groei in de werkgelegenheid verwacht. Met name voor de transport- en de informaticaberoepen zal de groei naar verwachting relatief groot zijn vergeleken met de werkgelegenheidstoename in deze beroepssectoren in de rest van Nederland. Ook voor de agrarische beroepen wordt in Limburg, in tegenstelling tot in de rest van het land, een werkgelegenheidstoename verwacht. Ook in dit geval liggen sectorale groeiverschillen aan deze groei ten grondslag. Zowel in de landbouw als in de voedings- en genotsmiddelenindustrie wordt de komende jaren een aanzienlijke groei van de werkgelegenheid in Limburg verwacht.

Tabel 1.5

Ontwikkeling aantal werkenden per beroepssector in 1998 en de periode 1997-2002 (gemiddelde jaarlijkse percentages)

\begin{tabular}{lcccc} 
Beroepssector & $\begin{array}{l}\text { aantal werkenden } \\
\text { Limburg } \\
1995-1996\end{array}$ & $\begin{array}{l}\text { Limburg } \\
1998\end{array}$ & $\begin{array}{l}\text { Limburg } \\
1997-2002 \\
\%\end{array}$ & $\begin{array}{l}\text { Nederland } \\
1997-2002 \\
\%\end{array}$ \\
& & & & \\
& & & & \\
\hline & 25.000 & 0,0 & 0,8 & 0,8 \\
Pedagogische beroepen & 7.000 & 2,2 & 1,3 & 1,5 \\
Culturele beroepen & 20.000 & 0,8 & 0,8 & $-0,1$ \\
Agrarische beroepen & 118.500 & 0,8 & 0,7 & 1,0 \\
Technische en industrieberoepen & 25.500 & 3,4 & 3,1 & 2,0 \\
Transportberoepen & 21.500 & 1,1 & 0,8 & 0,9 \\
Medische en paramedische beroepen & 107.500 & 3,3 & 2,8 & 2,5 \\
Economisch-administratieve beroepen & 8.500 & 6,2 & 4,5 & 3,5 \\
Informaticaberoepen & 9.500 & 3,4 & 3,2 & 2,8 \\
Sociaal-culturele beroepen & 76.000 & 1,8 & 1,6 & 2,0 \\
Verzorgende en dienstverl. beroepen & 8.000 & $-0,5$ & 0,0 & 0,2 \\
Openbare orde en veiligheidsberoepen & & & & \\
Totaal (inclusief beroep onbekend) & 434.500 & & & \\
& & & &
\end{tabular}

Bron: CBS/ROA

\subsection{Werkgelegenheidsontwikkeling en arbeidsmarktperspectief naar opleidingsniveau}

Tot 2002 wordt in Limburg een jaarlijkse werkgelegenheidsgroei van 1,6\% verwacht. Wanneer echter een onderscheid gemaakt wordt naar de verschillende opleidingsniveaus blijkt de vraagontwikkeling aanzienlijk uiteen te lopen. 
Tabel 1.6 geeft een overzicht van de verwachte uitbreidingsvraag naar opleidingsniveau. De voorspelde uitbreidingsvraag is gebaseerd op ontwikkelingen aan de vraagzijde van de arbeidsmarkt. Door aanpassingsreacties op de discrepanties tussen vraag en aanbod kan de feitelijke ontwikkeling van het aantal werkenden met een bepaalde opleidingsachtergrond in de praktijk afwijken van de uitbreidingsvraag.

Tabel 1.6

Verwachte uitbreidingsvraag en het arbeidsmarktperspectief per opleidingsniveau tot 2002

\begin{tabular}{lcllll}
\hline Opleidingsniveau & $\begin{array}{l}\text { aantal werkenden } \\
\text { Limburg, } \\
1995-1996\end{array}$ & $\begin{array}{l}\text { Limburg } \\
1997-2002 \\
\%\end{array}$ & $\begin{array}{l}\text { Nederland } \\
1997-2002 \\
\%\end{array}$ & $\begin{array}{l}\text { ITA* } \\
\text { Limburg }\end{array}$ & $\begin{array}{l}\text { ITA }^{*} \\
\text { Nederland }\end{array}$ \\
\hline & & & & & \\
Basisonderwijs & 38.000 & $-3,6$ & $-3,8$ & 1,14 & 1,07 \\
MAVO/VBO & 106.000 & $-0,0$ & $-1,0$ & 1,00 & 0,99 \\
HAVO/NWO/MBO/LLW & 192.000 & 3,3 & 2,6 & 0,87 & 0,98 \\
HBO & 74.500 & 2,9 & 3,2 & 0,90 \\
WO & 20.000 & 3,6 & 4,5 & 0,93 \\
\hline
\end{tabular}

Bron: CBS/ROA

${ }^{*}$ Indicator Toekomstige Arbeidsmarktperspectieven ${ }^{13}$

Uit de tabel blijkt dat voor het Basisonderwijs een forse daling van de vraag wordt verwacht. In Limburg zal de jaarlijkse daling naar verwachting 3,6\% zijn, hetgeen een iets geringere daling is dan landelijk wordt verwacht. Ook op MAVO/VBO-niveau is de uitbreidingsvraag negatief. In Limburg is de krimp van de vraag voor degenen met dit opleidingsniveau echter verwaarloosbaar klein, terwijl landelijk de jaarlijkse krimp $1 \%$ bedraagt. Op $\mathrm{HAVO/VWO/MBO/LLW-niveau}$ is de verwachte uitbreidingsvraag daarentegen fors. In Limburg wordt een jaarlijkse groei van de werkgelegenheid voor degenen met dit opleidingsniveau van 3,3\% verwacht, hetgeen duidelijk hoger is dan landelijk. Op HBO- en WO-niveau valt de groei van de werkgelegenheid in Limburg echter wat lager uit dan landelijk.

Deze cijfers illustreren duidelijk dat er sprake is van een upgradingsproces van de opleidingseisen. Op MBO-niveau en hoger is er sprake van een positieve uitbreidingsvraag, terwijl de vraag naar VBO'ers en mensen met MAVO of Basisonderwijs naar verwachting zal dalen. De tabel laat zien dat het upgradingproces in Limburg wat trager verloopt dan in de rest van het land. Enerzijds is de krimp op de lagere niveaus wat kleiner, anderzijds is de verwachte groei op HBO- en WO-niveau wat lager. Het industriële karakter van de Limburgse werkgelegenheid speelt hierbij een belangrijke rol. Het gemiddelde opleidingsniveau van de werkgelegenheid in de dienstensector is namelijk aanzienlijk hoger

13. De ITA is een indicator voor de verwachte krapte op de arbeidsmarkt. Hoe hoger de krapte, hoe lager de ITA en hoe beter de arbeidsmarktperspectieven. 
dan in de industriële sector.

Naast een eventuele groei van de vraag, vormt de vervangingsvraag als gevolg van pensionering, vervroegde uittreding of arbeidsongeschiktheid een tweede bron van baanopeningen voor nieuwkomers op de arbeidsmarkt. Door het totaal van de verwachte baanopeningen te confronteren met de verwachte arbeidsmarktinstroom en de direct inzetbare werkzoekenden kunnen de arbeidsmarktperspectieven per opleidingsniveau worden aangegeven. Voor de verschillende opleidingsniveaus is in tabel 1.6 de zogeheten Indicator Toekomstige Arbeidsmarktperspectieven (ITA) vermeld. Naarmate de ITA kleiner is, zijn er minder instromers in verhouding tot het aantal baanopeningen en is het arbeidsmarktperspectief dus gunstiger.

Tabel 1.6 laat zien dat voor het MBO/Leerlingwezen-niveau de perspectieven voor nieuwkomers in Limburg duidelijk beter zijn dan landelijk. Hierbij spelen twee factoren een rol. In de eerste plaats is, zoals de tabel laat zien, de uitbreidingsvaag naar verwachting veel hoger in Limburg dan in de rest van Nederland. In de tweede plaats zal ook de vervangingsvraag naar verwachting hoger zijn door de snelle vergrijzing van de Limburgse beroepsbevolking. Op VBO-niveau is het arbeidsmarktperspectief in Limburg vergelijkbaar met de rest van Nederland. Enerzijds is de uitbreidingsvraag in Limburg wat lager; anderzijds zal de vervangingsvraag, opnieuw als gevolg van de vergrijzing van de beroepsbevolking, wat hoger zijn dan in de rest van Nederland. Voor het Basisonderwijs is het perspectief in Limburg aanzienlijk slechter dan landelijk. Hieraan ligt een opvallend lage vervangingsvraag in Limburg ten grondslag.

Overigens kunnen er binnen de verschillende opleidingsniveaus nog sterk uiteenlopende arbeidsmarktperspectieven bestaan. Op elk niveau komen zowel opleidingstypen met goede tot zeer goede als opleidingstypen met matige of slechte perspectieven voor. In hoofdstuk 4 zal hierop nader worden ingegaan.

De keerzijde van een goed arbeidsmarktperspectief voor nieuwkomers op de arbeidsmarkt wordt gevormd door de knelpunten in de personeelsvoorziening die werkgevers zullen ervaren. Wanneer het perspectief goed is, zal de instroom kleiner zijn dan het aantal baanopeningen. Dit betekent dat werkgevers problemen zullen ondervinden bij het aantrekken van nieuw personeel. In Limburg zullen dus met name op MBO/Leerlingwezenniveau de knelpunten in de personeelsvoorziening aanzienlijk groter zijn in vergelijking met de rest van het land. Dergelijke arbeidsmarktknelpunten zouden een bedreiging kunnen vormen voor de economische groei in de provincie. Dit temeer daar middelbaar opgeleiden een strategische rol spelen in de concurrentiepositie van het bedrijfsleven ${ }^{14}$. Daarbij gaat het niet zozeer om het innovatieve potentieel van de beroepsbevolking, maar vooral om de kwaliteit van de productie en de dienstverlening. Een adequate studiekeuzevoorlichting is

14. Zie bijvoorbeeld R. Ryan (ed.) International Comparison of Vocational Education and Training for Intermediate Skills, Falmer Press, London, 1991. 
van groot belang voor het verminderen van de knelpunten op de arbeidsmarkt. Een optimaal opleidingsaanbod zou de macrodoelmatigheid van het beroepsonderwijs zoveel mogelijk moeten faciliteren (zie hoofdstuk 7). Daarnaast is het bij- en omscholingsbeleid gericht op het niet direct inzetbare aanbod van (langdurig) werkzoekenden de komende jaren van cruciale betekenis voor het voorkomen van knelpunten in de personeelsvoorziening die een belemmering zouden kunnen vormen voor de economische groei in Limburg. In hoofdstuk 6 zal hier nader op worden ingegaan. 


\section{$2.1 \quad$ Inleiding}

Dit hoofdstuk brengt de actuele situatie op de Limburgse arbeidsmarkt in beeld. Drie aspecten staan daarbij centraal. Eerst zal worden ingegaan op de werkgelegenheidsstructuur in Limburg. Gezien het feit dat Limburg in vergelijking met de rest van het land een duidelijk afwijkende economische structuur kent waarin de industrie een relatief grote plaats inneemt, is het van belang inzicht te verkrijgen in de implicaties die dit heeft voor de werkgelegenheidsstructuur. Aandacht wordt geschonken aan de vraag hoe de werkgelegenheidsstructuur naar bedrijfssector, beroepsgroep en opleidingstype eruitziet. Daarnaast worden verschillen met de landelijke structuur belicht. In de tweede plaats zal vraag en aanbod op de Limburgse arbeidsmarkt nader worden belicht. De omvang en samenstelling van enerzijds de openstaande vacatures en anderzijds het beschikbare aanbod van niet-werkende werkzoekenden staat hierbij centraal. Dit hoofdstuk mondt ten slotte uit in een analyse van de kwantitatieve en kwalitatieve discrepanties op de Limburgse arbeidsmarkt. Er wordt getracht een antwoord te geven op de vraag in hoeverre er op dit moment voldoende geschikte werkzoekenden beschikbaar zijn om de openstaande vacatures te vervullen en in hoeverre er voldoende vacatures zijn om de werkzoekenden aan een baan te helpen. Tevens wordt aandacht geschonken aan de achterliggende oorzaken van deze aansluitingsproblemen.

\subsection{De Limburgse werkgelegenheidsstructuur}

De werkgelegenheid naar bedrijfssector

In Limburg waren, gemiddeld genomen, de afgelopen twee jaar 434.500 mensen werkzaam. Dit is ruim $7 \%$ van de werkzame bevolking in Nederland. De Limburgse werkgelegenheidsstructuur wijkt echter duidelijk af van het landelijke beeld. Figuur 2.1 illustreert dit. De industrie neemt in Limburg een veel belangrijker plaats in dan in de rest van Nederland. In Limburg is bijna een kwart van de werkgelegenheid in de industrie te vinden; landelijk is dit slechts ongeveer $15 \%$. Met name de werkgelegenheid in de metaalindustrie en in de overige industrie is in Limburg relatief hoog. In Limburg werkt $13,6 \%$ van de werkenden in de metaal, terwijl dit percentage landelijk 8,3 bedraagt. Het hoge werkgelegenheidsaandeel in Limburg van de metaalindustrie vindt met name zijn oorsprong in het relatief grote belang van de elektrotechnische en van de transportmiddelenindustrie in Limburg. De overige industrie is goed voor bijna $5 \%$ van de Limburgse werkgelegenheid. Op landelijk niveau is het aandeel van deze sector slechts $3,4 \%$. Met name de hout- en bouwmaterialenindustrie en de papierindustrie dragen bij aan dit relatief grote verschil. Het industriële karakter van de werkgelegenheid in Limburg impliceert tevens dat de andere sectoren relatief klein zijn vergeleken met het landelijke beeld. Dat geldt met name voor de dienstverlenende sectoren. Terwijl landelijk ruim $40 \%$ van de werkenden een baan heeft in de dienstensectoren, is dit percentage in Limburg slechts ongeveer $35 \%$. 
Ook binnen Limburg zijn er duidelijke verschillen in de werkgelegenheidsstructuur. Figuur 2.2 illustreert dit. De landbouw is in Noord- en Midden-Limburg relatief groot; ruim $8 \%$ van de werkenden in deze regio is in deze sector werkzaam. Dit is niet alleen veel hoger dan in Zuid-Limburg, waar slechts $1 \%$ van de werkenden emplooi vindt in de genoemde sector, maar ook meer dan tweemaal zo hoog als het landelijk gemiddelde van $4 \%$. Het industriële karakter van de werkgelegenheid in Limburg komt in Noord- en Midden-Limburg veel sterker tot uiting dan in Zuid-Limburg. In Noord- en Midden-Limburg is meer dan een kwart van de werkenden in de industrie werkzaam; in Zuid-Limburg is dit ruim $20 \%$. Bovendien zijn er duidelijke verschillen in samenstelling van de industriële werkgelegenheid. De chemische sector is in Zuid-Limburg relatief groot, terwijl in Noord- en Midden-Limburg de metaalindustrie het leeuwendeel (bijna tweederde) van de industriële werkgelegenheid voor zijn rekening neemt. Gezien het grote aandeel van de landbouw en de industrie, is het niet verrassend dat de dienstensectoren en de overheidssector in Noord- en Midden-Limburg kleiner zijn dan in Zuid-Limburg. Het relatief kleine aandeel van de dienstensectoren in Limburg vergeleken met Nederland wordt dan ook voor een belangrijk deel veroorzaakt door de afwijkende werkgelegenheidsstructuur in Noord- en Midden-Limburg.

Figuur 2.1

De werkgelegenheid naar bedrijfssector in Limburg in vergelijking met Nederland, gemiddelde 1995-1996, in procenten

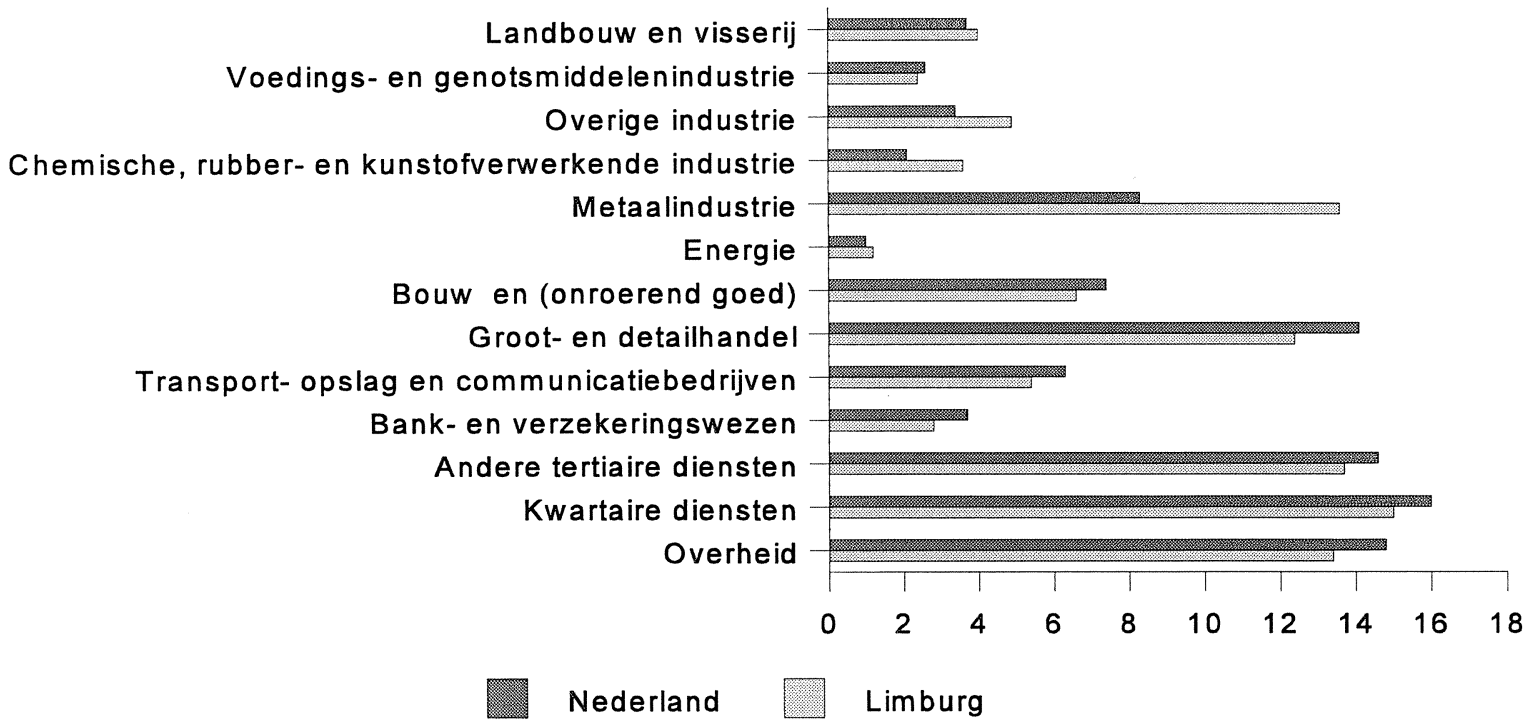

Bron: CBS/ROA 
Figuur 2.2

De werkgelegenheid naar bedrijfssector in Zuid-Limburg en Noord- en Midden-Limburg, gemiddelde 1995-1996, in procenten ${ }^{15}$

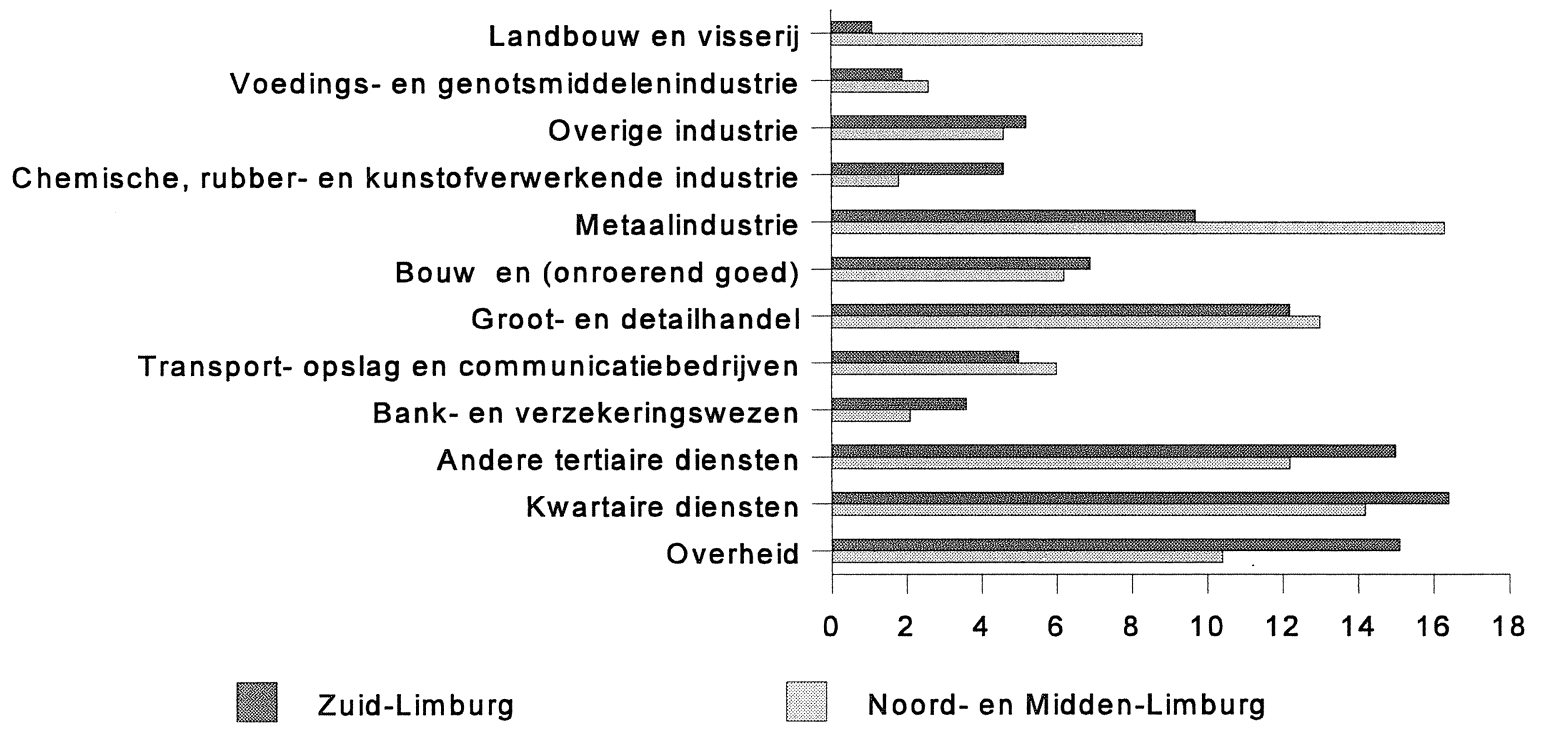

\section{Bron: CBS/ROA}

De werkgelegenheid naar beroepsgroep

Tabel 2.1 geeft een overzicht van de belangrijkste beroepsgroepen in de Limburgse werkgelegenheid. De boekhouders en secretaresses vormen de grootste beroepsgroep. In Limburg zijn 24.000 mensen in deze beroepsgroep werkzaam. Daarnaast zijn meer dan 15.000 mensen werkzaam als chauffeur, verkoper, monteur of commercieel employé. Terwijl tabel 2.1 een beeld geeft van het absolute belang van beroepsgroepen in de werkgelegenheid, geeft tabel 2.2 aan welke beroepsgroepen in Limburg relatief groot zijn vergeleken met Nederland. De tabel weerspiegelt het industriële karakter van de Limburgse werkgelegenheidsstructuur. Met uitzondering van de juridisch en fiscaal medewerkers bevat tabel 2.2 beroepsgroepen die voor een belangrijk deel in de industrie te vinden zijn.

15. De sector 'energie' is niet in figuur 2.2 opgenomen omdat de cijfers niet voldoen aan de ondergrens voor publicatie. 
Tabel 2.1

Beroepsgroepen met het hoogste aantal werkenden in Limburg, gemiddelde 1995-1996

aantal

werkenden

Boekhouders en secretaresses

24.000

Chauffeurs

18.500

Verkopers

18.500

Monteurs

16.500

Commercieel employés

15.500

Verzorgend personeel

15.000

Receptionisten en adm. employés

14.500

Bouwvakkers

13.500

Interieurverzorgers

10.500

Hulpkrachten horeca en verzorging

10.500

Bron: CBS/ROA

Tabel 2.2

Beroepsgroepen met een relatief hoog tot zeer hoog aandeel in de Limburgse werkgelegenheid vergeleken met Nederland, gemiddelde 1995-1996

Beroepsgroep aandeel Limburg typering

t.o.v. Nederland

zeer hoog

zeer hoog

hoog

hoog

hoog

hoog

Bankwerkers en lassers $\quad 1,41$

Mechanisch operators

1,37

Bron: CBS/ROA

De werkgelegenheid naar opleidingstype

Tabel 2.3 geeft een overzicht van de meest voorkomende opleidingsachtergronden van de werkzame personen in Limburg. Uit de tabel blijkt dat nog steeds 38.000 werkenden in Limburg slechts Basisonderwijs hebben gevolgd. Dit is $8,7 \%$ van de werkzamen. In vergelijking met de rest van Nederland is dit relatief hoog. Gemiddeld is het werkgelegenheidsaandeel voor mensen met alleen Basisonderwijs in Nederland slechts $7,9 \%$. Daarnaast blijkt het aantal werkzamen met name groot te zijn in een aantal technische, verzorgende en algemeen vormende opleidingstypen. 
Tabel 2.3

Opleidingstypen met het hoogste aantal werkenden in Limburg, gemiddelde 1995-1996

Opleidingstype aantal

werkenden

Basisonderwijs

38.000

MAVO

30.500

HAVONWO

19.500

$\mathrm{MBO} / \mathrm{LLW}$ administratie

19.000

$\mathrm{MBO} / \mathrm{LLW}$ handel

19.000

VBO verzorging

17.000

$\mathrm{MBO} / \mathrm{LLW}$ verzorging

16.000

MBO/LLW werktuigbouw

12.500

VBO mechanische techniek

11.500

MBO/LLW elektrotechniek

11.000

\section{Bron: CBS/ROA}

Een vergelijking van de opleidingsachtergronden van de werkenden in Limburg met die van de werkzame bevolking in Nederland weerspiegelt opnieuw het industriële karakter van de Limburgse economie, zoals tabel 2.4 laat zien. In deze tabel nemen de technische opleidingen een belangrijke plaats in. Dit beeld sluit aan bij figuur 2.1 en tabel 2.2 die aangaven dat in Limburg de industrie relatief belangrijk is. Daarnaast zijn de verzorgende opleidingen en MBO/LLW horeca relatief belangrijke opleidingen voor de werkgelegenheid in Limburg. Op HBO-niveau blijkt alleen de elektrotechnische richting een relatief groot aandeel in de werkgelegenheid te hebben in vergelijking met het landelijke beeld. Overigens moet opgemerkt worden dat voor veel HBO-opleidingen het aandeel in de werkgelegenheid in Limburg relatief laag is. De oorzaak hiervan kan voor een belangrijk deel gevonden worden in het feit dat de dienstensector, waar veel hoger opgeleiden werk vinden, in Limburg relatief klein is ${ }^{16}$.

16. Het aantal werkenden met een universitaire opleiding is in Limburg te klein om goed te kunnen vergelijken met Nederland. 


\section{Tabel 2.4}

Opleidingstypen met een relatief hoog tot zeer hoog aandeel in de Limburgse werkgelegenheid vergeleken met Nederland, gemiddelde 1995-1996

\section{Opleidingstype}

aandeel Limburg

t.o.v. Nederland typering

zeer hoog
hoog
hoog
hoog
hoog
hoog
hoog
hoog
hoog

MBO/LLW procestechniek

VBO mechanische techniek

VBO verzorging

HBO elektrotechniek

MBO/LLW werktuigbouw

MBO/LLW horeca

$\mathrm{MBO} / \mathrm{LLW}$ automatisering

VBO horeca en levensmiddelentechniek

$\mathrm{MBO} / \mathrm{LLW}$ verzorging

\section{2,35}

1,38

1,32

1,30

1,25

1,24

1,22

1,21

1,16
Bron: CBS/ROA

\subsection{Vacatures}

\section{Vacatures naar bedrijfssector}

Een overzicht van de openstaande vacatures biedt een momentopname van de knelpunten die er aan de vraagzijde van de arbeidsmarkt optreden. In deze paragraaf worden twee indicatoren gepresenteerd. Ten eerste wordt een indicatie gegeven van de vacaturegraadhet aantal vacatures per 1.000 werkenden - en ten tweede van het percentage langdurig openstaande vacatures. De tabel laat zien dat de vacaturegraad hoog tot zeer hoog is in de handel, het bank- en verzekeringswezen en de andere tertiaire diensten. Dit impliceert niet noodzakelijkerwijs dat in deze bedrijfssectoren de problemen om geschikte mensen te vinden het grootst zijn. Een hoge vacaturegraad geeft echter wel aan dat het relatief grote inspanningen vergt om te voorzien in de rekruteringsbehoefte, vanwege het grote aantal nieuwkomers dat bedrijven moeten aantrekken als gevolg van de groei in de werkgelegenheid of de vervangingsbehoefte. De vacaturegraad is daarentegen laag in de chemie, de energiesector en de kwartaire diensten. In deze sectoren worden derhalve relatief weinig nieuwkomers aangetrokken. Analoog aan de hierboven gemaakte opmerking over de implicaties van een hoge vacaturegraad betekent dit niet noodzakelijkerwijs dat de rekruteringsproblemen in deze sectoren klein zijn. In specifieke deelsectoren of segmenten van de arbeidsmarkt kunnen de knelpunten groot zijn. Een lage vacaturegraad is echter wel een aanwijzing voor relatief kleine rekruteringsinspanningen gerelateerd aan de omvang van de bedrijfssector. 
Tabel 2.5

Openstaande vacatures naar bedrijfssector in Limburg, februari 1997

\begin{tabular}{|c|c|c|c|c|}
\hline Bedrijfssector & $\begin{array}{c}\text { vacature- } \\
\text { graad } \\
\% o\end{array}$ & typering & $\begin{array}{l}\text { percentage } \\
\text { langdurig } \\
\text { openstaand }\end{array}$ & typering \\
\hline Landbouw en visserij & 11 & gemiddeld & 27 & gemiddeld \\
\hline Voedings- en genotsmiddelenindustrie & 11 & gemiddeld & 22 & gemiddeld \\
\hline Overige industrie & 11 & gemiddeld & 26 & gemiddeld \\
\hline Chemische, rubber- en kunststofverw. industrie & 8 & laag & 18 & laag \\
\hline Metaalindustrie & 13 & gemiddeld & 39 & zeer hoog \\
\hline Energie & 2 & laag & 25 & gemiddeld \\
\hline Bouw en onroerend goed & 20 & gemiddeld & 30 & hoog \\
\hline Groothandel en detailhandel & 24 & hoog & 19 & laag \\
\hline Transport, opslag en communicatie & 21 & gemiddeld & 22 & gemiddeld \\
\hline Bank- en verzekeringswezen & 27 & hoog & 20 & laag \\
\hline Andere tertiaire diensten & 47 & zeer hoog & 22 & gemiddeld \\
\hline Kwartaire diensten & 10 & laag & 22 & laag \\
\hline Overheid & 12 & gemiddeld & 27 & laag \\
\hline
\end{tabular}

Bron: Arbeidsvoorziening/CBS/ROA

Het percentage moeilijk vervulbare vacatures vormt een meer direct signaal voor het bestaan van rekruteringsproblemen in een sector. In de metaalindustrie en de bouw staat een groot percentage van de vacatures langer dan drie maanden open. In de chemie, de handel, het bank- en verzekeringswezen, de kwartaire diensten en bij de overheid is het percentage langdurig openstaande vacatures daarentegen laag.

Wanneer beide indicatoren dezelfde kant op wijzen, vormt dat een sterke aanwijzing voor het al dan niet bestaan van knelpunten in de personeelsvoorziening van een sector. Wanneer een hoge vacaturegraad gepaard gaat met een hoog percentage moeilijk vervulbare vacatures, hebben bedrijven niet alleen veel moeite met het vervullen van vacatures, maar zijn de gevolgen van het openstaan van deze vacatures bovendien sterk merkbaar in het productieproces. De rekrutering van personeel staat bij deze bedrijven dan ook onder grote druk. Dit lijkt vooral het geval te zijn in de metaalindustrie, de bouw en de tertiaire diensten. Gezien het gemiddeld tot hoge aandeel van jongeren in deze sectoren, speelt de ontgroening hierbij een belangrijke rol. Daarnaast is er, met name in de metaalindustrie en de bouw, sprake van een afnemende belangstelling bij de werkzoekenden om banen in deze sectoren te accepteren. In de tertiaire diensten worden de rekruteringsproblemen met name veroorzaakt door een tekort aan sociale, commerciële en leidinggevende vaardigheden bij de werkzoekenden ${ }^{17}$. Wanneer een lage vacaturegraad gepaard gaat met een laag percentage moeilijk vervulbare vacatures, hebben bedrijven niet alleen relatief weinig moeite met het vervullen van de vacatures, ook de gevolgen van het openstaan van deze vacatures zijn makkelijker op te vangen. Het rekruteringsbeleid van

17. Regionaal Bestuur voor de Arbeidsvoorziening Limburg, Beleidsplan 1997, 1996. 
bedrijven in deze sectoren staat dan ook veel minder onder druk. Dit lijkt vooral het geval te zijn in de chemie en de kwartaire diensten.

\section{Vacatures naar beroepsgroep}

Een overzicht van de vacatures naar bedrijfssector geeft vooral aan welke bedrijven te maken hebben met rekruteringsproblemen. In aanvulling daarop geeft een overzicht van de vacatures naar beroepsgroep aan in welke beroepssegmenten van de arbeidsmarkt deze problemen zich met name voordoen. Tabel 2.6 geeft een overzicht van de beroepsgroepen met een (zeer) hoge vacaturegraad. Tabel 2.6 laat opmerkelijk genoeg zien dat vooral lagere beroepsgroepen gekenmerkt worden door een hoge vacaturegraad. Dit kan twee oorzaken hebben. Enerzijds is de vervangingsvraag als gevolg van uitstroom in de lagere beroepen vaak hoger, anderzijds worden vacatures voor hogere functies vaak via interne promoties opgevuld waardoor er zogenaamde vacatureketens ontstaan die uiteindelijk leiden tot een externe vacature in een lager beroep.

Tabel 2.6

Beroepsgroepen met een hoge tot zeer hoge vacaturegraad in Limburg, februari 1997

Beroepsgroep
vacature-
graad
$\% 0$

$\begin{array}{lll}\text { Assemblagepersoneel } & 86 & \text { zeer hoog } \\ \text { Kantoorhulpen, inpakkers en colporteurs } & 61 & \text { zeer hoog } \\ \text { Aspirant politie-agenten, soldaten en beveiligingshulpkrachten } & 59 & \text { zeer hoog } \\ \text { Systeemanalisten } & 43 & \text { hoog } \\ \text { Hulpkrachten horeca en verzorging } & 43 & \text { hoog } \\ \text { Verkopers } & 40 & \text { hoog } \\ \text { Interieurverzorgers } & 37 & \text { hoog } \\ \text { Commercieel employés } & 36 & \text { hoog } \\ \text { Productiemedewerkers } & 35 & \text { hoog } \\ \text { Receptionisten en administratieve employés } & 34 & \text { hoog }\end{array}$

Bron: Arbeidsvoorziening/CBS/ROA

Tabel 2.7 geeft een overzicht van de beroepsgroepen die gekenmerkt worden door een zeer hoog percentage moeilijk vervulbare vacatures. Uit de tabel blijkt dat niet alleen lage beroepsgroepen, zoals metaalarbeiders en verpleeghulpen en leerling verpleegkundigen, maar ook middelbare beroepsgroepen, zoals de productieplanners gekenmerkt worden door een hoog percentage vacatures dat langer dan drie maanden open staat.

Opnieuw vormt het in dezelfde richting wijzen van beide vacature-indicatoren een indicatie voor het al dan niet optreden van knelpunten in het betreffende arbeidsmarktsegment. Twee beroepsgroepen zijn zowel in tabel 2.6 als tabel 2.7 terug te vinden: de aspirant politie- en beveiligingshulpkrachten en soldaten en de hulpkrachten horeca en verzorging. Daarnaast vallen de productiemedewerkers, de metaalarbeiders en het assemblagepersoneel net 
buiten de boot in één van de tabellen. Deze beroepsgroepen worden derhalve gekenmerkt door knelpunten bij het vinden van geschikt personeel voor de openstaande vacatures. De vacaturegraad is hoog en bovendien staat een hoog percentage vacatures langdurig open. Uit een in opdracht van Arbeidsvoorziening door ETIL en Intomart uitgevoerd onderzoek blijkt dat volgens de werkgevers niet alleen het niet aansluiten van de opleiding van de werkzoekenden op de gevraagde kwalificaties vaak een probleem vormt. Ook het ontbreken van werkervaring speelt een belangrijke rol. Bij de productiemedewerkers wordt daarnaast vaak het ontbreken van de juiste houding en de juiste sociale vaardigheden als een belangrijke oorzaak van het niet kunnen vervullen van vacatures genoemd ${ }^{18}$. Het in de tabellen 2.6 en 2.7 geschetste beeld sluit gedeeltelijk aan bij hetgeen bij de bedrijfssectoren geconcludeerd werd. De metaalindustrie, waarin veel metaalarbeiders en assemblagepersoneel werken, wordt momenteel geconfronteerd met grote rekruteringsproblemen. De vacatureproblemen voor beveiligingshulpkrachten en de hulpkrachten horeca en verzorging zijn vooral in de tertiaire diensten terug te vinden.

Tabel 2.7

Beroepsgroepen met een zeer hoog percentage moeilijk vervulbare vacatures in Limburg, februari 1997

\begin{tabular}{lll} 
Beroepsgroep & $\%$ & typering \\
\hline Metaalarbeiders & & zeer hoog \\
Verpleeghulpen & 67 & zeer hoog \\
Winkeliers & 50 & zeer hoog \\
Aspirant politie/beveiligingshulpkrachten/soldaten & 47 & zeer hoog \\
Monteurs/controleurs elektrotechnische producten & 45 & zeer hoog \\
Café- en snackbarhouders & 43 & zeer hoog \\
Productieplanners & 43 & zeer hoog \\
Hulpkrachten horeca en verzorging & 42 & zeer hoog
\end{tabular}

Bron: Arbeidsvoorziening/ROA

Het onderzoek van het ETIL met betrekking tot de industrie en handel bevestigt een aantal van de in de tabellen 2.6 en 2.7 aangegeven knelpunten in de personeelsvoorziening. De industrie wordt geconfronteerd met een tekortschietend aanbod van monteurs. Verder ervaart de industrie tekorten aan mechanische en procesoperators. In de handel is er vooral een tekort aan verschillende soorten verkooppersoneel en algemene medewerkers. De krappe arbeidsmarkt voor kantoorhulpen, inpakkers en colporteurs is volgens het ETILonderzoek het gevolg van het geringer aantal studenten, dat bereid is dit werk als bijbaantje te doen. Ook wordt het steeds moeilijker de vacatures voor verkopers te vervullen. Eén van de oorzaken is dat bedrijven het aantal kleine 'verkoopbaantjes' willen verminderen. De

18. Van Camp, H., Kwalitatieve informatie over de Limburgse arbeidsmarkt: tabellenboek telefonische vacature-enquête Limburg, werdocument I, ETIL, Maastricht, 1997a. 
voorkeur gaat uit naar verkooppersoneel dat minimaal 20 uur per week inzetbaar is ${ }^{19}$.

\section{Vacatures naar opleidingstype}

Vacatures hebben doorgaans in meer of mindere mate betrekking op een vraag naar specifieke kwalificaties. Een overzicht van de vacatures naar opleidingstype geeft inzicht in de problemen die ondervonden worden bij het vinden van personeel met een bepaalde opleidingsachtergrond. Tabel 2.8 geeft een overzicht van de opleidingstypen die gekenmerkt worden door een hoge tot zeer hoge vacaturegraad. De tabel laat zien dat de opleidingen met een (zeer) hoge vacaturegraad niet geconcentreerd zijn in een bepaalde opleidingsrichting of op een bepaald opleidingsniveau. Opleidingen die gekenmerkt worden door een groot aantal vacatures ten opzichte van het aantal werkenden zijn op alle niveau's en in verschillende vakrichtingen te vinden. Zowel uit deze cijfers als uit de werkgeversenquête van ETIL en Intomart kan echter geconcludeerd worden dat de nadruk lijkt te liggen op opleidingen in de technische richting.

Tabel 2.8

Opleidingstypen met een hoge tot zeer hoge vacaturegraad in Limburg, februari 1997

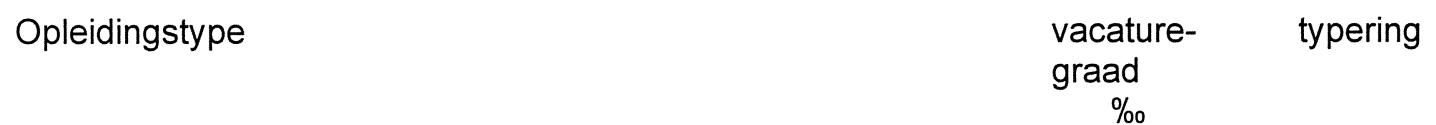

$\begin{array}{lrc}\text { VBO bouwtechniek } & 135 & \text { zeer hoog } \\ \text { HBO accountancy en bedrijfseconomie } & 126 & \text { zeer hoog } \\ \text { HBO elektrotechniek } & 112 & \text { zeer hoog } \\ \text { MBO sociaal-cultureel } & 84 & \text { zeer hoog } \\ \text { MBO/LLW mechanische techniek } & 74 & \text { zeer hoog } \\ \text { MBO/LLW handel } & 61 & \text { hoog } \\ \text { HBO lerarenopleiding econ. en maatschappij } & 39 & \text { hoog }\end{array}$

Bron: Arbeidsvoorziening/CBS/ROA

In tabel 2.9 wordt een overzicht gegeven van de opleidingstypen die een hoog tot zeer hoog percentage moeilijk vervulbare vacatures kennen. Deze tabel laat zien dat opleidingstypen met een hoog percentage vacatures die langer dan drie maanden open staan vooral te vinden zijn in een aantal technische en medische richtingen en in de horeca-richtingen. Vooral bij de VBO-richtingen landbouw en natuurlijke omgeving en bouwtechniek en bij de $\mathrm{MBO} /$ Leerlingwezen-richtingen mechanische techniek en werktuigbouwkunde, verpleging en horeca is er sprake van rekruteringsproblemen. Bij deze opleidingen is de vacaturegraad gemiddeld tot hoog en is er bovendien sprake van een hoog percentage moeilijk vervulbare vacatures. Bij VBO bouwtechniek noemen werkgevers het ontbreken van werkervaring als

19. Van Camp, H., Kwalitatieve informatie over de Limburgse arbeidsmarkt: moeilijk vervulbare vacatures verder onder de loep genomen, werkdocument II, ETIL, Maastricht, $1997 b$. 
belangrijkste oorzaak voor de rekruteringsproblemen ${ }^{20}$. Ook de in de tabellen 2.8 en 2.9 geschetste vacatureproblematiek naar opleidingstype weerspiegelt het beeld van de rekruteringsproblemen per bedrijfssector. De rekruteringsproblemen in de tertiaire diensten en de metaalindustrie spitsen zich vooral toe op de wervingsproblemen bij bovengenoemde opleidingstypen. Het beeld uit tabel 2.9 wordt bevestigd door het kwalitatieve onderzoek van het ETIL in de industrie. Daaruit blijkt eveneens dat voornamelijk de vacatures waarvoor personeel met een middelbaar technische opleiding gevraagd wordt moeilijker te vervullen zijn $^{21}$.

Tabel 2.9

Opleidingstypen met een hoog tot zeer hoog percentage moeilijk vervulbare vacatures in Limburg, februari 1997

$\begin{array}{lll}\text { Opleidingstype } & \% & \text { typering }\end{array}$

$\begin{array}{lll}\text { VBO horeca } & 50 & \text { zeer hoog } \\ \text { MBO/LLW installatietechniek } & 50 & \text { zeer hoog } \\ \text { MBO/LLW verpleging } & 46 & \text { zeer hoog } \\ \text { MBO/LLW beweging en therapie } & 43 & \text { zeer hoog } \\ \text { VBO landbouw en natuurlijke omgeving } & 38 & \text { hoog } \\ \text { MBO/LLW horeca } & 35 & \text { hoog } \\ \text { VBO bouwtechniek } & 32 & \text { hoog } \\ \text { MBO/LLW grafische techniek } & 31 & \text { hoog } \\ \text { MBO/LLW werktuigbouw } & 27 & \text { hoog } \\ \text { MBO/LLW bouw } & 25 & \text { hoog } \\ \text { MBO/LLW operationele techniek } & 25 & \text { hoog }\end{array}$

Bron: Arbeidsvoorziening/ROA

\subsection{Werkzoekenden}

In paragraaf 2.3 werd de vraagzijde van de arbeidsmarkt belicht door middel van een overzicht van de openstaande vacatures. In deze paragraaf staat de aanbodzijde centraal met een overzicht van de bij Arbeidsvoorziening ingeschreven niet-werkende werkzoekenden. Achtereenvolgens wordt aandacht geschonken aan de werkzoekenden naar beroepsgroep en naar opleidingstype ${ }^{22}$.

20. Zie Van Camp, H, 1997a, op. cit.

21. Zie Van Camp, H, 1997b, op cit.

22. Bij werkzoekenden is eigenlijk alleen de opleidingsachtergrond een persoonskenmerk. Aangezien Arbeidsvoorziening het wensberoep van een ingeschrevene registreert kan ook een indicatie gegeven worden van de werkzoekenden naar beroepsgroep. Een overzicht van de werkzoekenden naar bedrijfssector is daarentegen niet mogelijk. Werkzoekenden zijn in principe op zoek naar een bepaald soort functie en niet naar een baan in een specifieke sector. 
Wanneer een werkzoekende zich inschrijft bij het arbeidsbureau, wordt onder andere het wensberoep geregistreerd. Dit maakt het mogelijk inzicht te krijgen in de verdeling van de werkzoekenden over de beroepsgroepen. In tabel 2.10 wordt een overzicht gegeven van de beroepsgroepen waarin er sprake is van een hoog tot zeer hoog percentage werkzoekenden.

\section{Tabel 2.10}

Beroepsgroepen met een hoog tot zeer hoog aantal niet-werkende werkzoekenden als percentage van de werkgelegenheid in Limburg, maart 1997

\begin{tabular}{lrl}
\hline Beroepsgroep & $\%$ & typering \\
\hline Productiemedewerkers & 109 & zeer hoog \\
Kantoorhulpen, inpakkers en colporteurs & 74 & zeer hoog \\
Interieurverzorgers & 42 & zeer hoog \\
Hulpkrachten horeca en verzorging & 39 & hoog \\
Boekhouders en secretaresses & 24 & hoog \\
\hline
\end{tabular}

Bron: Arbeidsvoorziening/ROA

Vooral elementaire beroepen zoals kantoorhulpen, inpakkers en colporteurs, productiemedewerkers en interieurverzorgers worden gekenmerkt door een zeer hoog percentage werkzoekenden.

Zoals tabel 2.11 laat zien worden deze beroepsgroepen tevens gekenmerkt door een hoog percentage langdurig werkzoekenden. Deze tabel laat tevens zien dat ook op middelbaar en hoger niveau een aantal beroepsgroepen gekenmerkt wordt door een hoog percentage werkzoekenden dat meer dan een jaar ingeschreven is bij het arbeidsbureau ${ }^{23}$. Overigens dient opgemerkt te worden dat de term hoog hier gebruikt is als een relatief begrip, waarbij een vergelijking wordt gemaakt met de andere beroepen. Daarbij moet worden beseft dat het werkzoekendenbestand van Arbeidsvoorziening in het algemeen wordt gekenmerkt door een hoog percentage langdurig werkzoekenden. Dit betekent dat beroepsgroepen waarbij het percentage lager is dan $73 \%$ relatief gezien al beschouwd worden als beroepsgroepen met een laag langdurig-werkloosheidspercentage.

Langdurige werkloosheid vormt een indicatie voor een grote afstand tot de arbeidsmarkt. Het faseringssysteem van Arbeidsvoorziening biedt een nadere kijk op problemen die werkzoekenden ondervinden bij het zoeken naar een baan. Aan werkzoekenden wordt door

23. Opgemerkt dient te worden dat dit niet noodzakelijkerwijs impliceert dat deze werkzoekenden meer dan een jaar zonder werk zitten, omdat het vinden van werk niet altijd betekent dat men zich laat uitschrijven als werkzoekende bij het arbeidsbureau. 
Tabel 2.11

Beroepsgroepen met een hoog tot zeer hoog percentage langdurig werkzoekenden in Limburg, maart 1997

Beroepsgroep $\quad \% \quad \% \quad$ typering

$\begin{array}{ll}\text { Taalkundigen } & 97\end{array}$

zeer hoog

Kunstenaars

Laders en lossers

zeer hoog

Conciërges en huisbewaarders

zeer hoog

Organisatiedeskundigen

hoog

Assistent accountants

hoog

Docenten 2e zonder specialisatie

hoog

Onderwijskundigen en pedagogen

hoog

Vakkenvullers

Interieurverzorgers

hoog

hoog

Schoen- en kleermakers

hoog

Bibliotheekassistenten

hoog

Werktuigbouwkundig ontwerper en hoofd techn. dienst

Productiemedewerkers

hoog

hoog

Bron: Arbeidsvoorziening/ROA

Arbeidsvoorziening een fase toegekend die een indicatie vormt voor de afstand tot de arbeidsmarkt en voor het traject dat nodig is om de betreffende werkzoekende een volwaardige plek op de arbeidsmarkt te geven. Er worden vier fasen onderscheiden. Wanneer een werkzoekende in 'fase 1' wordt ingedeeld, is hij of zij direct bemiddelbaar en is er geen aanvullende scholing of begeleiding nodig om de afstand tot de arbeidsmarkt verder te verkleinen. Hoe hoger de fase, hoe intensiever en langduriger het traject naar de arbeidsmarkt zal moeten zijn $^{24}$.

Het percentage werkzoekenden in fase 1 vormt derhalve een belangrijke indicator voor de 'kwaliteit' van de werkzoekenden op een bepaald arbeidsmarktsegment door aan te geven welk deel van de werkzoekenden direct inzetbaar is op de arbeidsmarkt. In tabel 2.12 wordt een overzicht gegeven van de beroepsgroepen met het hoogste en met het laagste percentage werkzoekenden in fase 1. Deze tabel laat zien dat de beroepsgroepen met een zeer laag percentage direct bemiddelbare werkzoekenden in fase 1 vooral te vinden zijn bij de elementaire beroepen aan de onderkant van de arbeidsmarkt. Bij deze beroepsgroepen is niet alleen sprake van een hoog werkloosheidspercentage en een hoog percentage langdurig werkzoekenden. De problematiek wordt nog versterkt door het feit dat de afstand tot de arbeidsmarkt voor deze werkzoekenden zeer groot is. Daarnaast is er sprake van een grote afstand tot de arbeidsmarkt bij de kunstenaars ${ }^{25}$.

24. Meer informatie is te vinden in de verklarende woordenlijst achterin dit rapport en in Arbeidsvoorziening Limburg, Bemiddelingsbestand Arbeidsvoorziening Limburg: een indeling in fasen, 1996.

25. In paragraaf 2.5 zal dieper op de fasering van de werkzoekenden worden ingegaan. 
Tabel 2.12

Beroepsgroepen met een zeer laag en een zeer hoog percentage werkzoekenden in fase 1, Limburg, maart 1997

\begin{tabular}{lcc} 
Beroepsgroep & $\%$ & typering \\
\hline Laders en lossers & 7 & zeer laag \\
Conciërges en huisbewaarders & 8 & zeer laag \\
Kunstenaars & 13 & zeer laag \\
Vakkenvullers & 15 & zeer laag \\
Productiemedewerkers & 15 & zeer laag \\
Interieurverzorgers & 17 & zeer laag \\
& & \\
Juridisch en fiscaal medewerkers & 65 & zeer hoog \\
Weg- en waterbouwkundige vakkrachten & 64 & zeer hoog \\
Technisch-bedriffskundig medewerkers & 59 & zeer hoog \\
Bouwvakkers & 55 & zeer hoog \\
Accountants & 54 & zeer hoog \\
Juristen & 53 & zeer hoog
\end{tabular}

Bron: Arbeidsvoorziening/ROA

Daarentegen is er bij de bouwvakkers sprake van een zeer hoog percentage direct bemiddelbare werkzoekenden. Dit illustreert het zeer specifieke karakter van dit arbeidsmarktsegment waarin er veel met kortdurende contracten gewerkt wordt en er derhalve veel mensen kortstondig werkloos zijn en ook makkelijk weer een baan vinden. Daarnaast blijken vooral hogere beroepsgroepen zoals technisch-bedrijfskundig medewerkers, landbouwkundigen, accountants en juristen als zeer goed bemiddelbaar beschouwd te worden.

\section{Werkzoekenden naar opleidingstype}

De opleidingsachtergrond vormt een belangrijke determinant van iemands arbeidsmarktpositie. Naast een overzicht van het percentage werkzoekenden naar beroepsgroep is derhalve ook inzicht in de opleidingsachtergrond van de werkzoekenden van groot belang. In tabel 2.13 wordt een overzicht gegeven van de opleidingstypen die gekenmerkt worden door een hoog tot zeer hoog percentage werkzoekenden ${ }^{26}$. Uit de tabel blijkt dat met name de lager opgeleiden geconfronteerd worden met relatief hoge werkzoekendenpercentages. Met name de opleidingen MAVO, VBO bouwtechniek, VBO administratie en handel en VBO verzorging vallen daarbij in negatieve zin op. Dit beeld sluit aan bij de hoge werkzoekendenpercentages in de elementaire en lagere beroepsgroepen. Opvallend is het hoge percentage werkzoekenden met als opleidingsachtergrond MBO/LLW informatica. Dit zou veroorzaakt kunnen zijn door het grote aantal werkzoekenden dat zijn arbeidsmarktkansen tracht te vergroten door het volgen van opleidingen en cursussen op

26. Opgemerkt dient te worden dat de opleidingsachtergrond niet alleen bepaald wordt door de gevolgde initiële opleiding. Ook met aanvullende scholing is hier rekening gehouden. 
het gebied van automatisering.

Tabel 2.13

Opleidingstypen met een hoog tot zeer hoog aantal werkzoekenden als percentage van de werkgelegenheid in Limburg, maart 1997

\begin{tabular}{lcl}
\hline Opleidingstype & $\%$ & typering \\
\hline & 111 & zeer hoog \\
VBO bouwtechniek & 60 & zeer hoog \\
VBO verzorging & 51 & zeer hoog \\
VBO administratie en handel & 39 & zeer hoog \\
MAVO & 38 & zeer hoog \\
MBO/LLW automatisering & 27 & hoog \\
HAVO/NWO & 26 & hoog \\
Basisonderwijs & 25 & hoog \\
MBO/LLW werktuigbouw en mechanische techniek & 22 & hoog \\
MBO sociaal-cultureel & 21 & hoog \\
VBO landbouw en natuurlijke omgeving & &
\end{tabular}

Bron: Arbeidsvoorziening/ROA

Tabel 2.14

Opleidingstypen met een hoog percentage langdurig werkzoekenden in Limburg, maart 1997

Opleidingstype $\quad \% \quad$ typering

$\begin{array}{lll}\text { MBO/LLW brood en banket } & 96 & \text { hoog } \\ \text { HBO uitvoerend en beeldend kunstenaar } & 94 & \text { hoog } \\ \text { MBO/LLW levensmiddelentechniek } & 93 & \text { hoog } \\ \text { HBO personeelswerk } & 93 & \text { hoog } \\ \text { MBO/LLW beweging en therapie } & 91 & \text { hoog } \\ \text { HBO leraar economie en maatschappij } & 89 & \text { hoog } \\ \text { Basisonderwijs } & 89 & \text { hoog }\end{array}$

Bron: Arbeidsvoorziening/ROA

In tabel 2.14 wordt een overzicht gegeven van een aantal grotere opleidingen die gekenmerkt worden door een hoog percentage langdurig werkzoekenden. De tabel geeft een divers beeld te zien. Opvallend is overigens wel dat de lagere opleidingen, met uitzondering van degenen met alleen Basisonderwijs, niet in deze tabel voorkomen. Overigens dient ook hier opgemerkt te worden dat de begrippen 'hoog' en 'laag' relatief zijn. Een langdurig-werkloosheidspercentage van $71 \%$ kan al als relatief laag getypeerd worden.

Een overzicht van het percentage werkzoekenden in fase 1 naar opleidingstype bevestigt de bovenstaande bevindingen. Terwijl direct bemiddelbare werkzoekenden duidelijk ondervertegenwoordigd zijn in de elementaire en lage beroepen, is dit bij de lagere opleidingen veel minder het geval en is het beeld divers, zoals tabel 2.15 laat zien ${ }^{27}$.

27. In paragraaf 2.5 zal dieper op de fasering van de werkzoekenden worden ingegaan. 
Tabel 2.15

Opleidingstypen met een hoog tot zeer hoog of een laag percentage werkzoekenden in fase 1 , Limburg, maart 1997

\begin{tabular}{lll} 
Opleidingstype & $\%$ & typering \\
\hline Basisonderwijs & & laag \\
MBO/LLW brood en banket & 10 & laag \\
MBO/LLW procestechniek & 15 & laag \\
MBO/LLW motorvoertuigentechniek & 16 & laag \\
VBO verzorging & 17 & laag \\
MBO/LLW geld, bank en belastingen & 18 & zeer hoog \\
HBO verpleegkunde & 52 & hoog \\
VBO Vervoer & 49 & hoog \\
MBO/LLW toerisme & 47 & hoog \\
HBO accountancy en bedrijfseconomie & 44 & \\
\hline
\end{tabular}

Bron: Arbeidsvoorziening/ROA

\subsection{Kwantitatieve en kwalitatieve discrepanties}

\section{Inleiding}

In de voorafgaande paragrafen zijn de vraag naar en het aanbod van arbeid in kaart gebracht. Deze analyses maken het mogelijk om in deze paragraaf door middel van een confrontatie van de openstaande vacatures en de niet-werkende werkzoekenden inzicht te verkrijgen in de actuele knelpunten op de Limburgse arbeidsmarkt. Alvorens in te gaan op de discrepanties naar respectievelijk bedrijfssector, beroepsgroep en opleidingstype zal eerst het raamwerk waarop deze paragraaf gebaseerd is uiteengezet worden.

\section{Discrepantiemaatstaven en typering arbeidsmarktkrapte}

Uitgangspunt is het eenvoudige principe dat een vergelijking van het aantal openstaande vacatures en het aantal niet-werkende werkzoekenden de vraag-aanbodverhouding in een arbeidsmarktsegment weergeeft. Wanneer het aantal openstaande vacatures het aantal werkzoekenden overtreft is er sprake van een tekort. Wanneer daarentegen het aantal werkzoekenden het aantal openstaande vacatures overtreft is er sprake van een overschot in het betreffende arbeidssegment. Een nuancering is hier echter op zijn plaats. Niet elke werkzoekende wordt als geschikt beschouwd om vacatures te vervullen. De afstand tot de arbeidsmarkt is niet voor iedere werkzoekende gelijk. Het is daarom zeer gebruikelijk om in discrepantie-analyses een onderscheid te maken tussen direct beschikbare werkzoekenden en werkzoekenden met een grotere afstand tot de arbeidsmarkt ${ }^{28}$.

Zoals reeds eerder opgemerkt, wordt in dit rapport het faseringsmodel van Arbeidsvoor-

28. J. Hartog, Tussen vraag en aanbod, Stenfert Kroese, Leiden, 1980. 
ziening gebruikt om de afstand van werkzoekenden tot de arbeidsmarkt te typeren. Hierbij wordt een onderscheid gemaakt in vier fasen. Werkzoekenden in fase 1 zijn onmiddellijk beschikbaar voor de arbeidsmarkt. Werkzoekenden in fase 2 en 3 hebben respectievelijk een kort of een langer scholings- of begeleidingsprogramma nodig om hun arbeidsmarktkansen te vergroten. Werkzoekenden in fase 4 worden daarentegen (voorlopig) niet in staat geacht een volwaardige plaats op de arbeidsmarkt te verwerven. Aangezien werkgevers primair geïnteresseerd zijn in mensen die direct inzetbaar zijn, ligt het voor de hand de arbeidsmarktkrapte op een bepaald arbeidsmarktsegment te definiëren als de verhouding tussen het aantal openstaande vacatures en het aantal werkzoekenden in fase 1 op het betreffende arbeidsmarktsegment. Wanneer de arbeidsmarktkrapte groter is dan éen, is er sprake van een tekort aan direct inzetbare werkzoekenden. Wanneer de arbeidsmarktkrapte kleiner is dan één is er sprake van een overschot.

Wanneer er sprake is van een tekort aan direct inzetbare werkzoekenden - dat wil zeggen als de arbeidsmarktkrapte groter is dan één - zullen de vacatures ook opgevuld moeten worden door de werkzoekenden die een grotere afstand tot de arbeidsmarkt hebben. Vanwege het tekort aan direct inzetbare werkzoekenden kunnen deze minder goed bemiddelbare werkzoekenden door middel van een scholings- of begeleidingstraject hun kansen op een baan aanzienlijk vergroten. De knelpuntsindicator geeft aan in hoeverre er werkzoekenden in fase 2 en 3 beschikbaar zijn. Het is tevens een indicator voor de arbeidsmarktkansen voor de werkzoekenden in fase 2 en 3 . De knelpuntsindicator is gedefinieerd als de verhouding tussen het aantal openstaande vacatures waarvoor geen werkzoekenden in fase 1 gevonden kunnen worden enerzijds en het aantal werkzoekenden in fase 2 en 3 anderzijds. Wanneer er sprake is van een overschot aan direct inzetbare werkzoekenden, is de knelpuntsindicator nihil; aangezien er meer dan genoeg direct inzetbare werkzoekenden zijn, zijn er geen knelpunten en zijn de mogelijkheden voor werkzoekenden in fase 2 en 3 om via een bijscholings- of begeleidingstraject hun arbeidsmarktkansen op korte termijn te vergroten nihil. Wanneer er sprake is van een tekort aan direct inzetbare werkzoekenden is er sprake van een knelpunt en zijn er reële arbeidsmarktkansen voor werkzoekenden in fase 2 en 3 . Wanneer de knelpuntsindicator bijvoorbeeld 0,30 bedraagt betekent dit dat 30\% van de werkzoekenden in fase 2 en 3 via een bijscholings- of begeleidingstraject aan een baan geholpen kan worden en eraan kunnen bijdragen dat de knelpunten in het betreffende segment verminderd kunnen worden.

De arbeidsmarktkrapte en de knelpuntsindicator maken het mogelijk een nadere typering te geven van de krapte op de arbeidsmarkt. Er worden drie situaties onderscheiden:

1. Een ruime arbeidsmarkt.

Een ruime arbeidsmarkt wordt gekenmerkt door een overschot aan direct inzetbare werkzoekenden. De arbeidsmarktkrapte is kleiner dan één. Voor werkzoekenden met een grotere afstand tot de arbeidsmarkt zijn de perspectieven gering. Bijscholing of nadere begeleiding zal op korte termijn niet tot een vergroting van de arbeidsmarktkansen leiden. Aanvullende indicaties voor het ruime karakter van een arbeidsmarkt zijn een hoge werkloosheid en een hoog percentage langdurig 
werkzoekenden.

2. Een krappe arbeidsmarkt met een kwantitatief tekort.

Wanneer er sprake is van een tekort aan direct inzetbare werkzoekenden, terwijl er op het betreffende arbeidsmarktsegment ook onvoldoende werkzoekenden met een wat grotere afstand tot de arbeidsmarkt beschikbaar zijn, is er sprake van een kwantitatief probleem. Er zijn eenvoudigweg te weinig werkzoekenden in het betreffende segment beschikbaar. De knelpuntsindicator is groter dan één. Dit betekent overigens ook dat de arbeidsmarktkansen voor werkzoekenden in fase 2 en 3 groot zijn. Gezien het grote aantal vacatures vergeleken met het totaal aantal werkzoekenden in dit segment is bijscholing of verdere begeleiding een bijzonder effectief middel om werkzoekenden met een grotere afstand tot de arbeidsmarkt aan het werk te helpen. Verdere aanwijzingen voor een krappe arbeidsmarkt zijn een hoge vacaturegraad en een hoog percentage langdurig openstaande vacatures.

3. Een krappe arbeidsmarkt met een kwalitatief aans/uitingsprobleem.

Wanneer er sprake is van een tekort aan direct inzetbare werkzoekenden, terwijl er voldoende werkzoekenden in fase 2 en 3 in het betreffende segment op zoek zijn naar een baan is er sprake van een kwalitatief aansluitingsprobleem. $\mathrm{Er}$ is weliswaar voldoende aanbod - de knelpuntsindicator is kleiner dan één - maar dit aanbod voldoet niet aan de gestelde eisen: de afstand tot de arbeidsmarkt is te groot. Vanuit de vacatureproblematiek aan de vraagzijde van de arbeidsmarkt is bijscholing of verdere begeleiding in dat geval een effectief middel. De arbeidsmarktkansen voor werkzoekenden in fase 2 en 3 zijn echter relatief klein. Er zijn veel werkzoekenden in fase 2 en 3 beschikbaar hetgeen betekent dat bijscholings- en begeleidingsprogramma's de werkloosheidsproblemen in dit segment niet drastisch zullen verminderen. Verdere aanwijzingen voor een krappe arbeidsmarkt zijn een hoge vacaturegraad en een hoog percentage langdurig openstaande vacatures.

Dit instrumentarium wordt gebruikt om de discrepanties naar beroepsgroep en naar opleidingstype in kaart te brengen. Deze maatstaven kunnen niet toegepast worden om inzicht te verkrijgen in de discrepanties naar bedrijfssector, aangezien werkzoekenden niet naar bedrijfssector zijn in te delen. De arbeidsmarktkrapte naar bedrijfssector is daarom gedefinieerd als het gewogen gemiddelde van de arbeidsmarktkrapte naar beroepsgroep. De wegingsfactor wordt hierbij bepaald door het aandeel van een beroepsgroep in het totaal aantal openstaande vacatures in een sector.

\section{Discrepanties naar bedrijfssector}

De arbeidsmarktkrapte naar bedrijfssector geeft een indicatie van de mate waarin bedrijfssectoren getroffen worden door een tekort aan direct inzetbare werkzoekenden in de arbeidsmarktsegmenten waarin zij nieuwe mensen werven. Figuur 2.3 geeft een overzicht 
van de arbeidsmarktkraptes ${ }^{29}$. De arbeidsmarktkrapte op de Limburgse arbeidsmarkt is momenteel hoog in de chemische, rubber en kunststofverwerkende industrie, de metaalindustrie en de andere tertiaire diensten. In deze sectoren zijn er relatief weinig werkzoekenden beschikbaar die meteen inzetbaar zijn en de openstaande vacatures kunnen opvullen. De problemen zijn het grootst in het bank- en verzekeringswezen. Voor elke 95 vacatures zijn er, gemiddeld genomen, 100 werkzoekenden beschikbaar. Dit beeld komt gedeeltelijk overeen met het beeld dat het overzicht van de openstaande vacatures liet zien. Met name in de metaalindustrie komen de discrepanties tot uiting in een hoog percentage langdurig openstaande vacatures. In de tertiaire dienstensectoren komen de rekruteringsproblemen vooral tot uiting in een hoge vacaturegraad. Omdat binnen deze bedrijfssectoren zowel bedrijfsklassen te vinden zijn die groeien als bedrijfsklassen die qua werkgelegenheid stabiel zijn of krimpen, kan dit hoge percentage vacatures zowel veroorzaakt worden door groei als door een grote vervangingsbehoefte.

29. De in figuur 2.3 en in de rest van deze paragraaf gepresenteerde discrepanties geven mogelijk een licht vertekend beeld, aangezien de vacaturecijfers betrekking hebben op februari 1997, terwijl de werkzoekendencijfers betrekking hebben op maart 1997. 
Figuur 2.3

Arbeidsmarktkrapte naar bedrijfssector in Limburg, februari-maart 1997

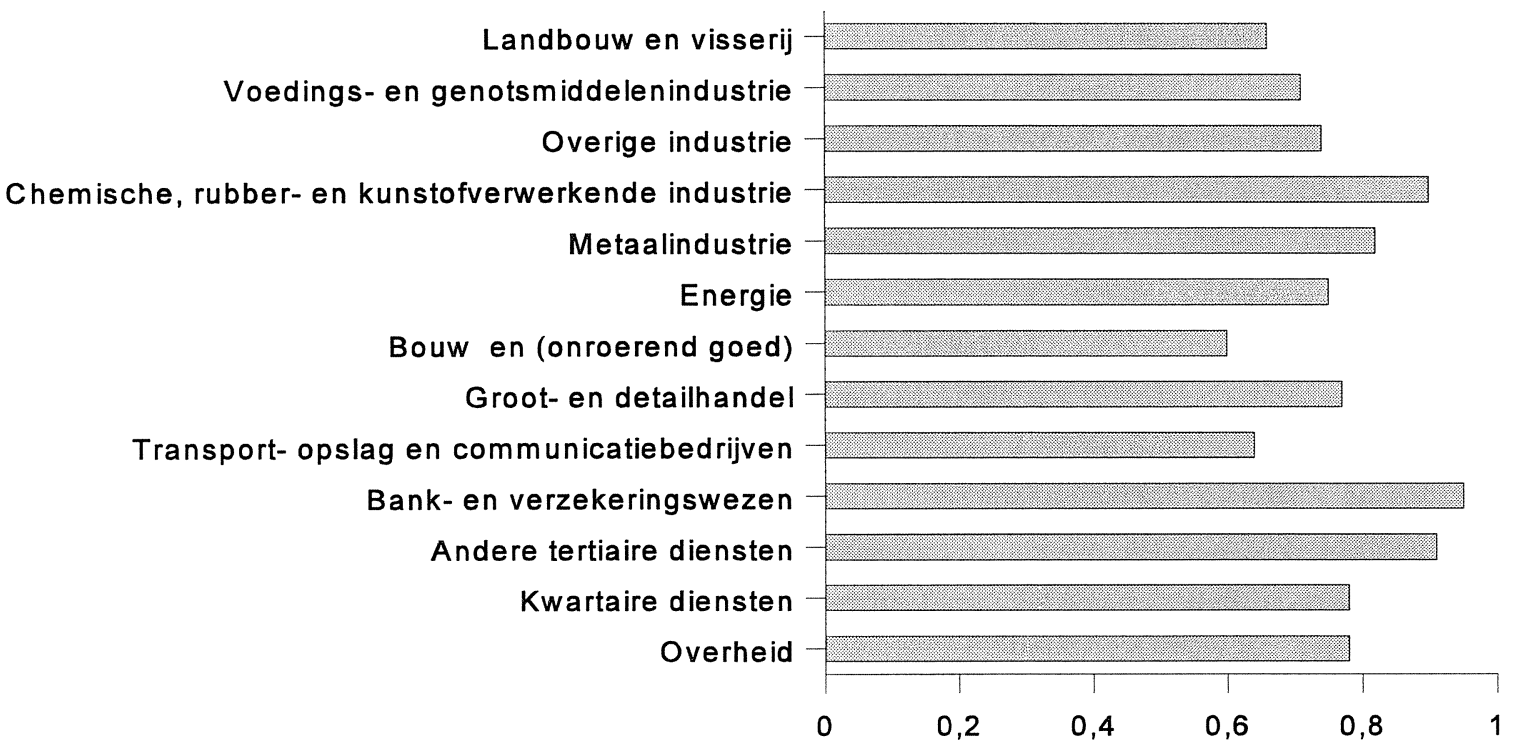

Bron: ROA

Met name in de bouw en, in mindere mate, bij de landbouw, de voedings- en genotsmiddelenindustrie en in de transportsector is de arbeidsmarktkrapte laag. Dit betekent dat bedrijven in deze sectoren kunnen putten uit een relatief groot aantal direct inzetbare werkzoekenden om hun vacatures te vervullen. Met name voor de bouw is dit een opmerkelijke uitkomst. Tabel 2.5 liet immers zien dat de bouwsector gekenmerkt wordt door een hoog percentage langdurig openstaande vacatures. Deze op het eerste gezicht paradoxale situatie kan verschillende oorzaken hebben. Ten eerste kunnen de rekruteringsproblemen in zeer specifieke segmenten optreden, terwijl er gemiddeld genomen geen problemen zijn. Ten tweede kan de oorzaak gelegen zijn in het feit dat de bouw niet aantrekkelijk gevonden wordt door de werkzoekenden ${ }^{30}$. Ten derde kan er sprake zijn van kwalitatieve aansluitingsproblemen. Enerzijds blijkt er vooral behoefte te zijn aan schoolverlaters, die schaars zijn; anderzijds wordt het opleidingsniveau van de werkzoekenden in de bouw vaak als te laag beschouwd ${ }^{31}$.

\section{Discrepanties naar beroepsgroep}

Een tekort aan direct inzetbare werkzoekenden in een specifiek arbeidsmarktsegment kan verschillende oorzaken hebben. Het probleem kan, zoals hierboven reeds uiteengezet,

30. Zie Corten, J.W., 'Dit jaar zijn 35.000 toetreders nodig om arbeidsbestand op peil te houden.', Bouw/Werk: de bouw in feiten, cijfers en analyses, 22e jaargang, 1997, nr. 2, blz. 8-12.

31. Corten, 1997, op. cit. 
kwantitatief of kwalitatief van aard zijn. In tabel 2.16 wordt een overzicht gegeven van de beroepsgroepen waarin er sprake is van een kwantitatief probleem. De in de tabel genoemde beroepsgroepen worden niet alleen gekenmerkt door een tekort aan direct inzetbare werkzoekenden - de indicator voor de arbeidsmarktkrapte is groter dan één maar ook is er een onvoldoende aanbod van werkzoekenden met een wat grotere afstand tot de arbeidsmarkt. De problemen lijken zich hierbij toe te spitsen op de automatiseringsberoepen en een aantal medische beroepen. Bij de systeemanalisten bijvoorbeeld is er slechts één direct inzetbare werkzoekende beschikbaar per 3,46 vacatures. Gezien het kwantitatieve karakter van de aansluitingsproblematiek op dit arbeidsmarktsegment - de knelpuntsindicator is groter dan één - zijn scholingsprogramma's een bijzonder effectief middel om de werkloosheid bij deze beroepsgroepen te verminderen. Voor elke werkzoekende systeemanalist in fase 2 en 3 zijn er bijvoorbeeld 2,65 vacatures beschikbaar. Om het tekort aan arbeidskrachten in deze segmenten aan te pakken, zijn bijscholingsprogramma's echter niet voldoende. Aangezien de knelpuntsindicator groter is dan één, kunnen niet alle openstaande vacatures door mensen in fase 2 en 3 opgevuld worden. Werving op andere arbeidsmarktsegmenten is noodzakelijk om werkzoekenden te vinden die via omscholing geschikt gemaakt kunnen worden voor de in tabel 2.16 genoemde beroepsgroepen.

Tabel 2.16

Beroepsgroepen met een kwantitatief tekort aan werkzoekenden in Limburg, februari-maart 1997

\begin{tabular}{lll} 
Beroepsgroep & $\begin{array}{l}\text { arbeidsmarkt- } \\
\text { krapte }\end{array}$ & $\begin{array}{l}\text { knelpunts- } \\
\text { indicator }\end{array}$ \\
\hline
\end{tabular}

$\begin{array}{lrr}\text { Systeemanalisten } & 3,46 & 2,65 \\ \text { Programmeurs } & 2,52 & 2,00 \\ \text { Werktuigbouwkundigen } & 2,46 & 2,88 \\ \text { Apothekersassistenten en medisch laboranten } & 2,10 & 1,13 \\ \text { Therapeuten en verpleegkundigen } & 2,01 & 1,40 \\ \text { Ziekenverzorgenden } & 1,97 & 1,33 \\ \text { Technisch-bedrijfskundig medewerkers } & 1,79 & 2,00\end{array}$

Bron: ROA

Wanneer een tekort aan direct inzetbare werkzoekenden gepaard gaat met een relatief groot aantal werkzoekenden met een grotere afstand tot de arbeidsmarkt is er sprake van een kwalitatief aansluitingsprobleem. In tabel 2.17 wordt een overzicht gegeven van de beroepsgroepen waarin er sprake is van een kwalitatief aansluitingsprobleem: de in de tabel genoemde beroepsgroepen worden weliswaar gekenmerkt door een tekort aan direct inzetbare werkzoekenden, maar er zijn voldoende werkzoekenden met een wat grotere afstand tot de arbeidsmarkt beschikbaar. Scholings- of begeleidingsprogramma's, gericht op het verkleinen van deze afstand, zijn een effectief middel om het tekort aan werkzoekenden te verminderen. Aangezien de knelpuntsindicator kleiner is dan één, zijn er voldoende werkzoekenden in fase 2 en 3 beschikbaar om het tekort te verhelpen. Voor de werkzoekenden zelf betekent dit echter dat slechts weinigen op korte termijn de stap naar 
een volwaardige plaats op de arbeidsmarkt zullen kunnen maken.

Tabel 2.17

Beroepsgroepen met een kwalitatief aansluitingsprobleem in Limburg, februari-maart 1997

Beroepsgroep

arbeidsmarkt-

knelpunts-

krapte

indicator

$\begin{array}{lrr}\text { Assistent accountants } & 2,16 & 0,05 \\ \text { Tolken, vertalers en schrijvers } & 1,81 & 0,52 \\ \text { Productieplanners } & 1,39 & 0,64 \\ \text { Receptionisten en administratieve employés } & 1,34 & 0,30 \\ \text { Assemblagepersoneel } & 1,26 & 0,35\end{array}$

Bron: ROA

In de tabellen 2.6 en 2.7 is aan twee andere indicatoren voor rekruteringsproblemen op de arbeidsmarkt aandacht geschonken: de vacaturegraad en het percentage langdurig openstaande vacatures. Het in tabel 2.6 en 2.7 geschetste beeld komt slechts gedeeltelijk overeen met de conclusies die uit de confrontatie van vraag en aanbod getrokken worden. Vier beroepsgroepen komen in beide analyses naar voren als arbeidsmarktsegmenten met een grote krapte: het assemblagepersoneel, de receptionisten, de systeemanalisten en de productieplanners.

Verschillen tussen beide analyses kunnen diverse oorzaken hebben. Ten eerste belichten beide analyses een verschillend aspect van het probleem. Met name de langdurig openstaande vacatures geven een indicatie van de wijze waarop de vraagzijde van de markt rekruteringsproblemen probeert te verhelpen. Wanneer bijvoorbeeld het probleem tijdelijk intern wordt opgelost door bijvoorbeeld overwerk, zal de vacature blijven openstaan. Wanneer daarentegen gekozen wordt voor bijvoorbeeld het in dienst nemen van uitzendkrachten komen de rekruteringsproblemen niet tot uiting in een hoog percentage langdurig openstaande vacatures. De beroepsgroep assemblagepersoneel is hiervan een goed voorbeeld. Deze beroepsgroep kent een hoge vacaturegraad en een tekort aan direct inzetbare werkzoekenden. Het percentage langdurig openstaande vacatures is daarentegen relatief laag, omdat via uitzendkrachten het rekruteringsprobleem op korte termijn verholpen wordt.

Een tweede oorzaak kan gelegen zijn in de eisen die vraag en aanbod stellen. Ondanks het feit dat er voldoende werkzoekenden zijn die geacht worden direct inzetbaar te zijn, hetgeen resulteert in een ruime arbeidsmarkt (de indicator voor de arbeidsmarktkrapte is kleiner dan één), kunnen werkgevers toch problemen hebben met het vinden van geschikte mensen, hetzij omdat deze werkzoekenden om één of andere reden toch niet aan hun wensen voldoen, hetzij omdat de banen niet aan de wensen van de werkzoekenden voldoen. Hierbij kan gedacht worden aan andere aspecten dan de inhoudelijke aansluiting tussen kwalificaties waarover de werkzoekenden beschikken en de gevraagde kwalificaties, waarop in dit rapport de nadruk ligt. Voorbeelden zijn leeftijd, de duur van het arbeidscontract, 
werktijden, duur van de werkweek, etc. De (detail)handel vormt een goed voorbeeld van deze problematiek. Consulenten van Arbeidsvoorziening wijzen op de aanhoudende vraag naar jeugdig personeel in de detailhandel, terwijl er sprake is van ontgroening van de beroepsbevolking. Anderzijds zijn werkzoekenden vaak op zoek naar een full-time baan, terwijl in de detailhandel, onder andere door verruiming van de openingstijden, steeds meer de nadruk komt te liggen op grotere part-time banen. In de industrie, zo geven consulenten aan, leggen werkgevers steeds meer de nadruk op flexibiliteit. Er worden steeds minder vaste contracten aangeboden en scholing wordt steeds minder gekoppeld aan een baangarantie, waardoor de banen voor werkzoekenden steeds minder aantrekkelijk worden. Daarnaast kampt de industrie met een imago-probleem ${ }^{32}$. De negatieve beeldvorming heeft vooral betrekking op de zware industrie (basismetaalindustrie in Limburg) en de afvalverwerking ${ }^{33}$.

Een derde oorzaak zou gelegen kunnen zijn in de heterogeniteit van de beroepsgroepen. De problemen kunnen zich in een zeer specifiek segment binnen deze beroepsgroep voordoen. Deze problemen leiden tot een hoog percentage langdurig openstaande vacatures, maar komen niet tot uiting in de arbeidsmarktkrapte. Ook binnen bedrijfssectoren kunnen tekorten op specifieke plekken optreden. Consulenten van Arbeidsvoorziening wijzen op de aantrekkingskracht van het werken bij grotere bedrijven, waardoor bij knelpunten op de arbeidsmarkt vooral kleine bedrijven meer moeite hebben met het vinden van geschikt personeel ${ }^{34}$. Bovendien, zo blijkt uit de diepte-interviews met bedrijven, kunnen grotere bedrijven rekruteringsproblemen beter opvangen door gebruik te maken van hun interne arbeidsmarkt ${ }^{35}$. Ten slotte kan er sprake zijn van regionale fricties. Terwijl er in Limburg als geheel op een bepaald arbeidsmarktsegment geen tekort is, kan dit in specifieke regio's wel het geval zijn. Zo wijzen consulenten van Arbeidsvoorziening erop dat er in Noord- en Midden-Limburg een tekort is aan zogenaamde CNC-metaalbewerkers, terwijl er in ZuidLimburg juist sprake is van een overschot ${ }^{36}$.

Met uitzondering van de bovengenoemde beroepsgroepen is er bij de elementaire en lagere beroepen sprake van een ruime arbeidsmarkt. Er zijn voldoende werkzoekenden in fase 1 om de openstaande vacatures te vervullen. Ook hier kan er desondanks sprake zijn van rekruteringsproblemen. Opnieuw worden deze dan niet veroorzaakt door een gebrekkige vakinhoudelijke aansluiting tussen vraag en aanbod, maar door de bovengenoemde aspecten. Eerder is hierbij het voorbeeld van de bouwvakkers al genoemd. Een tweede

32. Zie Van Camp, H., Kwalitatieve informatie over de Limburgse arbeidsmarkt: opzet en inhoud consulenten- en onderwijspanels, werkdocument III, ETIL, Maastricht, 1997c.

33. Zie Van Camp, H., 1997d, op. cit.

34. Zie Van Camp, H., 1997c, op. cit.

35. Zie Van Camp, H., 1997b, op. cit.

36. Zie Van Camp, H., 1997c, op. cit. 
voorbeeld vormt het elementaire productiepersoneel. De rekruteringsproblemen binnen deze beroepsgroep worden met name veroorzaakt door het feit dat de vraag geconcentreerd is in een beperkte regio (o.a. de Westelijke Mijnstreek) ${ }^{37}$. Ook voor veel hogere beroepsgroepen is de arbeidsmarktkrapte momenteel gering. Gezien het feit dat de arbeidsmarkt voor deze beroepsgroepen veel meer een landelijk karakter heeft, betekent dit niet dat werkzoekenden noodzakelijkerwijs moeilijk een baan zullen vinden. Het betekent echter wel dat de werkzoekenden in deze segmenten geografisch mobiel moeten zijn om werk te vinden.

\section{Discrepanties naar opleidingstype}

Ook naar opleidingstype kunnen de discrepanties in kaart gebracht worden. In tabel 2.18 wordt een overzicht gegeven van de opleidingstypen waarvoor er een kwantitatief tekort aan werkzoekenden bestaat. De in deze tabel genoemde opleidingstypen worden niet alleen gekenmerkt door een tekort aan direct inzetbare werkzoekenden - de indicator voor de arbeidsmarktkrapte is groter dan één - maar ook is er onvoldoende aanbod van werkzoekenden met een wat grotere afstand tot de arbeidsmarkt. De problemen lijken zich hierbij toe te spitsen op een aantal technische en commerciële opleidingen. De opleiding HBO accountancy en bedrijfseconomie wordt bijvoorbeeld gekenmerkt door het feit dat er slechts één werkzoekende beschikbaar is per 7,44 openstaande vacatures. De aansluitingsproblematiek is vooral kwantitatief van aard. Dit betekent dat scholingsprogramma's een bijzonder effectief middel zouden kunnen zijn om de werkloosheid onder mensen met de in tabel 2.18 genoemde opleidingsachtergrond te verminderen. De knelpuntsindicator is immers hoog. Voor elke werkzoekende in fase 2 en 3 met bijvoorbeeld de opleiding HBO accountancy en bedrijfseconomie zijn er bijna 10 openstaande vacatures beschikbaar. Om het tekort aan arbeidskrachten in deze segmenten aan te pakken zijn bijscholingsprogramma's echter niet toereikend. De knelpuntsindicator is voor de bovengenoemde opleidingstypen groter dan één, wat betekent dat niet alle openstaande vacatures door werkzoekenden in fase 2 en 3 opgevuld kunnen worden. Werving op andere arbeidsmarktsegmenten is noodzakelijk om werkzoekenden te vinden die via omscholing geschikt gemaakt kunnen worden voor de banen waaraan de vraag naar hierboven genoemde opleidingen ten grondslag ligt.

37. Zie Van Camp, H., 1997b, op. cit. 
Tabel 2.18

Opleidingstypen met een kwantitatief tekort aan werkzoekenden in Limburg, februari-maart 1997

Opleidingstype

arbeidsmarkt-

knelpunts-

krapte

indicator

$\begin{array}{llr}\text { HBO accountancy en bedrijfseconomie } & 7,44 & 9,97 \\ \text { HBO elektrotechniek } & 6,47 & 4,21 \\ \text { MBO/LLW handel } & 2,56 & 1,42 \\ \text { VBO beveiliging } & 2,35 & 1,08 \\ \text { MBO/LLW operationele techniek } & 2,04 & 1,71 \\ \text { VBO vervoer } & 1,63 & 1,26\end{array}$

Bron: ROA

Wanneer een tekort aan direct inzetbare werkzoekenden gepaard gaat met een relatief groot aantal werkzoekenden met een wat grotere afstand tot de arbeidsmarkt is er sprake van een kwalitatief aansluitingsprobleem. In tabel 2.19 wordt een overzicht gegeven van de opleidingstypen die gekenmerkt worden door een kwalitatief aansluitingsprobleem: de in de tabel genoemde opleidingstypen worden weliswaar gekenmerkt door een tekort aan direct inzetbare werkzoekenden, maar er zijn voldoende werkzoekenden met een wat grotere afstand tot de arbeidsmarkt beschikbaar. De knelpuntsindicator is kleiner dan één. Scholings- of begeleidingsprogramma's, gericht op het verkleinen van deze afstand, zijn in dit geval een effectief middel om het tekort aan direct inzetbare werkzoekenden te verminderen. Er zijn voldoende werkzoekenden in fase 2 en 3 beschikbaar om het tekort te verhelpen. Voor de werkzoekenden zelf betekent dit echter dat slechts een klein deel op korte termijn de stap naar een volwaardige plaats op de arbeidsmarkt zal kunnen maken. De in tabel 2.19 genoemde opleidingstypen vallen in twee categorieën uiteen. Ten eerste de opleidingen MBO/LLW procestechniek en horeca. De kwalitatieve aansluitingsproblemen binnen deze opleidingstypen sluiten aan bij het beeld dat per bedrijfssector en beroepsgroep geschetst is. Anderzijds worden de opleidingstypen HBO leraar basisonderwijs en HBO verpleegkunde gekenmerkt door een hoog percentage vrouwen die door de grotere nonparticipatie gemiddeld genomen een grotere afstand tot de arbeidsmarkt hebben.

Tabel 2.19

Opleidingstypen met een kwalitatief aansluitingsprobleem in Limburg, februari-maart 1997

Opleidingstype

arbeidsmarkt-

knelpunts-

krapte indicator

MBO/LLW procestechniek

2,40

0,49

$\mathrm{HBO}$ leraar basisonderwijs

1,82

0,60

MBO/LLW horeca

1,76

0,75

HBO leraar economie en maatschappij

$\mathrm{HBO}$ verpleegkunde

1,70

0,47

$1,44 \quad 0,91$

Bron: ROA 
In de tabellen 2.8 en 2.9 zijn twee aanvullende indicatoren voor rekruteringsproblemen belicht: de vacaturegraad en het percentage langdurig openstaande vacatures. Zoals reeds eerder is opgemerkt geven de drie in deze paragraaf gepresenteerde indicatoren elk een specifiek aspect van de aansluitingsproblematiek weer. Het in de tabellen 2.8 en 2.9 geschetste beeld komt slechts gedeeltelijk overeen met de conclusies die uit de confrontatie van vraag en aanbod getrokken kunnen worden. Dit is bijvoorbeeld het geval bij de opleidingstypen HBO accountancy en bedrijfseconomie, HBO elektrotechniek en HBO leraar economie en maatschappij. Deze opleidingen worden niet alleen gekenmerkt door een tekort aan direct inzetbare werkzoekenden, maar eveneens door een hoge vacaturegraad. De opleidingstypen MBO/LLW handel en MBO/LLW horeca kennen zowel een tekort als een hoog percentage moeilijk vervulbare vacatures. Bovendien is een groot aantal van de in tabel 2.8 en 2.9 genoemde opleidingstypen sterk gerelateerd aan de bouwberoepen. Zoals reeds eerder opgemerkt hebben de rekruteringsproblemen in de bouw een zeer specifiek karakter dat niet in de hier gepresenteerde discrepantiemaatstaven tot uiting komt.

Over het algemeen is er voor de opleidingstypen op VBO-niveau sprake van een ruime arbeidsmarkt. Het aantal direct inzetbare werkzoekenden overtreft het aantal openstaande vacatures. Uitzonderingen zijn de opleidingstypen VBO vervoer en VBO beveiliging. Dit beeld sluit aan bij het ruime karakter van de arbeidsmarkt voor de elementaire en lagere beroepsgroepen. Dit beeld illustreert tevens dat werkgevers steeds vaker Leerlingwezen als minimum-opleidingseis stellen bij het rekruteren van nieuw personeel.

\section{Discrepanties in de handel en industrie}

Een confrontatie van vraag en aanbod geeft aan in welke segmenten van de arbeidsmarkt er sprake is van knelpunten. Deze knelpunten komen onder meer tot uiting in moeilijk vervulbare vacatures. In opdracht van Arbeidsvoorziening is door ETIL en Intomart in een enquête onder werkgevers in de industrie en handel gevraagd om, indien zij te kampen hebben met moeilijk vervulbare vacatures, aan te geven wat volgens hen de dieperliggende oorzaken zijn van het moeilijk vervulbaar zijn van hun vacatures ${ }^{38}$. In tabel 2.20 wordt hiervan een overzicht gegeven. Het niet beschikbaar zijn van de voor de moeilijk vervulbare vacatures vereiste werkervaring blijkt een belangrijke knelpuntsfactor te zijn. Zowel in de industrie als in de handel wordt een gebrek aan werkervaring bij het beschikbare aanbod door de werkgevers als belangrijkste reden gezien voor de moeilijke vervulbaarheid van vacatures. Dit verklaart dat een hoog percentage moeilijk vervulbare vacatures niet noodzakelijkerwijs gepaard hoeft te gaan met een grote arbeidsmarktkrapte. Ook het tekortschieten van de werkervaring wordt als een belangrijk probleem gezien. Een gebrek aan sociale vaardigheden of een verkeerde houding wordt daarentegen, met name in de industrie, opvallend weinig genoemd. Mogelijk komt dit voort uit het relatief lage niet specifiek vaktechnische functie-niveau van de moeilijk vervulbare vacatures in de industrie en handel. In de diepte-interviews wordt daarentegen door de bedrijven in de handel en in de industrie juist wel de nadruk gelegd op het steeds groter wordend belang van de functie-

38. Zie Van Camp, H., 1997a, op. cit. 
eisen, zoals de wil om te blijven leren, de positieve werkhouding, de communicatieve vaardigheden en een klantgerichte instelling ${ }^{39}$. Aangezien in de diepte-interviews de nadruk op de (middel)grote bedrijven is gelegd, zijn deze vaardigheden blijkbaar vooral in deze grotere bedrijven van belang.

Tabel 2.20

Aard van de aansluitingsproblemen bij moeilijke vervulbaarheid van vacatures volgens werkgevers (in procenten), 1997

Aard aansluitingsprobleem

$\begin{array}{ll}\text { industrie } & \text { handel } \\ \% & \%\end{array}$

$\begin{array}{lrr}\text { te weinig werkervaring } & 28 & 17 \\ \text { te jong } & 4 & 2 \\ \text { te oud } & 1 & 2 \\ \text { niet de juiste opleidingsrichting } & 16 & 12 \\ \text { niet het juiste opleidingsniveau } & 14 & 7 \\ \text { niet de juiste houding/past niet in team } & 7 & 12 \\ \text { slechte sociale vaardigheden } & 3 & 7 \\ \text { te hoge salariseisen } & 3 & 7 \\ \text { niet eens met werktijden } & 1 & 0 \\ \text { anders } & 23 & 32 \\ \text { weet niet } & 0 & 5\end{array}$

Bron: ETIL/Intomart

Zoals reeds eerder opgemerkt, is ook aan consulenten van Arbeidsvoorziening - in de vorm van panels - gevraagd wat volgens hen de oorzaken van moeilijk vervulbare vacatures $z_{i j n}{ }^{40}$. Terwijl in de werkgeversenquête de nadruk lag op de aansluitingsproblematiek bij aanbieders op de arbeidsmarkt, is bij deze panels een onderscheid gemaakt naar oorzaken aan de vraag- en aan de aanbodzijde. Voor de industrie wijzen de consulenten, met betrekking tot de aanbodzijde, vooral op de gebrekkige aansluiting tussen onderwijs en arbeidsmarkt. $\mathrm{Er}$ is een tekort aan gekwalificeerde vaklieden, het opleidingsniveau van de werkzoekenden wordt als te laag ervaren en er is sprake van een minder goede aansluiting tussen theorie en praktijk. Dit beeld sluit aan op het beeld dat de werkgevers de opleidingsachtergrond van de werkzoekende als belangrijk knelpunt zien. Specifiek kan hierbij gewezen worden op het feit dat werkgevers steeds vaker Leerlingwezen als minimum-opleidingseis stellen bij het rekruteren van nieuw personeel ${ }^{41}$. Ook tekortschietende vaardigheden worden door de consulenten van Arbeidsvoorziening als belangrijk knelpunt gezien. Met betrekking tot de vraagzijde benadrukken de consulenten de (te) hoge eisen die gesteld worden door de werkgevers. Men is op zoek naar 'panklare'

39. Zie Van Camp, H., 1997b, op. cit.

40. Zie Van Camp, H., 1997c, op. cit.

41. Dit punt werd bijvoorbeeld expliciet genoemd bij een paneldiscussie met mensen uit het onderwijs. 
werknemers. Er wordt veelal om een combinatie van jongeren met ervaring gevraagd. Dit beeld bevestigt de grote nadruk die door werkgevers op werkervaring wordt gelegd, zoals uit tabel 2.20 naar voren komt. Aan laag gekwalificeerde banen, zoals bedieningsfuncties, worden als gevolg van de toenemende automatisering, bovendien steeds hogere vakinhoudelijke eisen gesteld. Tevens wordt een toenemend beroep gedaan op de flexibiliteit van werknemers, wat de intredebereidheid van werkzoekenden negatief beïnvloedt. Ten slotte speelt volgens de consulenten ook het slechte imago van het werken in de industrie een rol. Ook het onderwijs wijst overigens op het imago-probleem. De intermediairs voegen hieraan toe dat met name de zware industrie (de basismetaal) en de afvalverwerking met een negatieve beeldvorming te kampen hebben ${ }^{42}$.

Voor de handel wijzen de consulenten op de grote vraag naar jongeren, die, in combinatie met de ontgroening van de beroepsbevolking, tot steeds grotere knelpunten leidt. Ook in de handel worden door werkgevers steeds hogere eisen gesteld; eisen waaraan het aanbod op dit moment niet kan voldoen. Hierbij wordt in het bijzonder gewezen op de gevraagde combinatie van commerciële vaardigheden en specialistische kennis die voor verkoopadviserende werkzaamheden verlangd wordt. Een tweede probleem dat specifiek voor de handel van belang is, is het toenemend belang van part-time banen, mede als gevolg van de verruimde openingstijden. Werkzoekenden zijn daarentegen vaak op zoek naar een full-time baan. Ten slotte kampt ook de handel op de arbeidsmarkt met een imagoprobleem, wat volgens de consulenten vooral veroorzaakt wordt door de slechte arbeidsvoorwaarden en de geringe investeringen in human capital.

Een tekort aan geschikt personeel vraagt om maatregelen aan zowel de vraag- als de aanbodzijde van de arbeidsmarkt. In de ETIL/Intomart-enquête is aan de werkgevers in de handel en industrie gevraagd welke maatregelen zij genomen hebben om knelpunten op te lossen of te vermijden ${ }^{43}$. In tabel 2.21 wordt hiervan een overzicht gegeven. Deze cijfers illustreren dat werkgevers bij knelpunten in de personeelsvoorziening met name de werving intensiveren en uitbreiden. Dit geldt zowel voor de industrie als de handel. De eisen die gesteld worden aan nieuwe werknemers worden niet of nauwelijks aangepast. Ook het geven van aanvullende scholing wordt, met name in de handel, door werkgevers slechts in beperkte mate ingezet als instrument om moeilijk vervulbare vacatures te vervullen.

42. Zie Van Camp, H., 1997d, op. cit.

43. Zie Van Camp, H., 1997a, op. cit. 
Tabel 2.21

Door het bedrijf genomen maatregelen om moeilijk vervulbare vacature te vervullen (in procenten), 1997

Maatregel industrie

$\% \quad$ hande

geen maatregelen

intensiever gezocht binnen regio

buiten regio gaan zoeken

meer wervingskanalen gebruikt

opleidingseisen aangepast

ervaringseisen aangepast

leeftijdseisen aangepast

eigen werknemers opgeleid

nieuwkomers opgeleid

uitzendkracht ingeleend

werk uitbesteed

hoger salaris geboden

anders

weet niet

$\begin{array}{rr}15 & 19 \\ 13 & 15 \\ 8 & 15 \\ 22 & 19 \\ 2 & 2 \\ 2 & 0 \\ 1 & 2 \\ 6 & 6 \\ 6 & 2 \\ 7 & 6 \\ 3 & 0 \\ 1 & 0 \\ 15 & 11 \\ 1 & 4\end{array}$

Bron: ETIL/Intomart

De diepte-interviews die gevoerd zijn met het bedrijfsleven wijzen op dit punt op de extra mogelijkheden waarover grote bedrijven beschikken om rekruteringsproblemen het hoofd te bieden. Bij de grote bedrijven speelt, met name in de industrie, de bedrijfsinterne arbeidsmarkt een belangrijke rol. De interne arbeidsmarkt biedt ondernemingen de mogelijkheid om personeel binnen het bedrijf over te plaatsen. Hierbij gaat het vaak ook om interne loopbaanperspectieven voor het personeel bij tekorten in specifieke delen van de onderneming. Door het volgen van aanvullende scholing of zogenaamde 'on-the-job training' stromen werknemers door naar gelijkwaardige of hogere functies. Daardoor hoeft men slechts personeel te werven voor startersfuncties. Naast het feit dat de grote industriële ondernemingen meer gebruik maken van de mogelijkheden van de interne arbeidsmarkt dan de handelsondernemingen, heeft over het algemeen het personeelsbeleid in de industrie een professioneler karakter $^{44}$.

44. Zie Van Camp, H., 1997b, op. cit. 


\section{$3.1 \quad$ Inleiding}

In de komende twee hoofdstukken wordt een beeld geschetst van de toekomstige ontwikkelingen op de Limburgse arbeidsmarkt. In hoofdstuk 4 zullen de ontwikkelingen op de middellange termijn tot het jaar 2002 in kaart gebracht worden. In dit hoofdstuk staan de korte-termijnontwikkelingen centraal op basis waarvan een beeld zal worden geschetst van de Limburgse arbeidsmarkt in 1998. Een belangrijke doelgroep van de kortetermijnprognoses wordt gevormd door de werkgevers die deze arbeidsmarktinformatie kunnen gebruiken ten behoeve van hun personeelsbeleid. De prognoseresultaten stellen hen in staat het personeelsbeleid af te stemmen op de verwachte knelpunten op de arbeidsmarkt. Hierbij kan het zowel gaan om het wervings- en selectiebeleid als om het interne scholingsbeleid, het eventuele outplacementbeleid, e.d.. Een tweede doelgroep vormen de organisaties die betrokken zijn bij het scholingsbeleid dat als belangrijk sturend element kan fungeren om vraag en aanbod dichter bij elkaar te brengen. De prognoses bieden de mogelijkheid te anticiperen op de toekomstige verhoudingen tussen vraag en aanbod op de Limburgse arbeidsmarkt.

De opzet van dit hoofdstuk is als volgt. Na een korte bespreking van het prognosemodel wordt in paragraaf 2 aandacht geschonken aan de te verwachten ontwikkelingen in de arbeidsvraag per beroepsgroep en per opleidingstype als gevolg van de verwachte ontwikkelingen in de werkgelegenheid in de verschillende bedrijfssectoren en de verschuivingen in de beroepen- en opleidingenstructuur binnen bedrijfssectoren: de zogenaamde uitbreidingsvraag. In paragraaf 3 staat de te verwachten vraag als gevolg van de mobiliteit en uitstroom van werkenden centraal: de zogenaamde vervangingsvraag. Uitbreidings- en vervangingsvraag tezamen vormen de baanopeningen voor nieuwkomers die in paragraaf 4 zullen worden belicht. In paragraaf 5 wordt aandacht geschonken aan de te verwachten ontwikkelingen aan de aanbodzijde, in het bijzonder de verwachte instroom van schoolverlaters. In paragraaf 6 ten slotte leidt een confrontatie van vraag en aanbod tot een beeld van de verwachte aansluitingsproblemen op de Limburgse arbeidsmarkt op de korte termijn. In het bijzonder zullen hier de knelpunten in de personeelsvoorziening centraal staan.

\section{Het prognosemodel}

Bij het maken van zowel de korte- als de middellange-termijnprognoses voor de Limburgse arbeidsmarkt is gebruik gemaakt van een stroomcijfer-aanpak die nauw aansluit bij de aanpak zoals die door het ROA in het kader van het landelijk Informatiesysteem Onderwijs- 
Arbeidsmarkt is ontwikkeld ${ }^{45}$. Bij deze aanpak worden prognoses gemaakt van de werkgelegenheidsontwikkelingen en van de stromen van en naar de arbeidsmarkt in een bepaalde toekomstige periode. Deze benadering heeft als voordeel dat de processen in kaart worden gebracht die van belang zijn voor de ontwikkeling van vraag en aanbod op de arbeidsmarkt. Bovendien wordt op deze manier vermeden dat gebruik moet worden gemaakt van de vaak sterk fluctuerende vacaturecijfers. De prognoses voor Limburg worden opgesteld voor in totaal 127 beroepsgroepen en 56 opleidingstypen op VBO- en MBO/Leerlingwezen-niveau ${ }^{46}$.

Figuur 3.1 geeft een overzicht van het prognosemodel. De stroomgrootheid die van belang is voor de vraagzijde van de arbeidsmarkt is het aantal baanopeningen. Baanopeningen kunnen voortkomen uit uitbreidingsvraag of vervangingsvraag. De uitbreidingsvraag geeft de ontwikkeling van de werkgelegenheid in een bepaalde beroepsgroep of voor een bepaald opleidingstype weer. De prognoses voor de uitbreidingsvraag bouwen voort op de regionale werkgelegenheidsprognoses voor bedrijfssectoren van $\mathrm{TNO} / \mathrm{Inro}^{47}$. Omdat binnen een bedrijfssector bepaalde beroepsgroepen zich sneller ontwikkelen dan anderen, vertaalt het ROA deze bedrijfssectorontwikkelingen naar de uitbreidingsvraag per beroepsgroep. De ontwikkelingen in de beroepsgroepenstructuur binnen bedrijfssectoren blijken in de praktijk slechts in beperkte mate per regio te verschillen. Daarom is ervoor gekozen de verschuivingen in de beroepenstructuur van de werkgelegenheid in de verschillende bedrijfssectoren te baseren op landelijke ontwikkelingen. Dit heeft als belangrijk voordeel dat de voorspellingen gebaseerd zijn op meer betrouwbare data. Vervolgens wordt bepaald welke implicaties de voorspelde groei van de werkgelegenheid in de verschillende beroepsgroepen heeft voor de uitbreidingsvraag per opleidingstype. Ook hierbij wordt gebruik gemaakt van een prognose van de landelijke ontwikkeling in de gevraagde kwalificaties binnen de verschillende beroepsgroepen. De uitbreidingsvraag per opleidingstype heeft betrekking op het aantal personen met een bepaalde opleidingsachtergrond, dat werkgevers zouden willen aannemen. De feitelijke ontwikkeling van het aantal werkenden per opleidingstype zal hier van kunnen afwijken door de invloed van de ontwikkeling van het aanbod op de schaarsteverhoudingen en de als gevolg daarvan optredende substitutieprocessen.

45. Researchcentrum voor Onderwijs en Arbeidsmarkt, De arbeidsmarkt naar opleiding en beroep tot 2002, ROA-1997/7, Maastricht.

46. De prognoses per opleidingstype worden opgesteld voor de opleidingen op VBO- en MBO-Leerlingwezenniveau. Twee argumenten kunnen voor deze beperking gegeven worden. Vanuit theoretisch oogpunt kan gesteld worden dat de arbeidsmarkt voor HBO'ers en academici een meer landelijk karakter heeft. Vanuit praktisch oogpunt is deze beperking ingegeven door het feit dat regionale cijfers betreffende de onderwijsdeelname voor de hogere opleidingen vooralsnog niet beschikbaar zijn. Overigens zal in hoofdstuk 4 wel een indicatie worden gegeven van de arbeidsmarktsituatie voor hoger opgeleiden op de middellange termijn.

47. TNO/Inro, Regionale arbeidsmarktprognose 1997-2002, Delft, 1997. 
Figuur 3.1

Globale opzet prognosemodel

Daarnaast ontstaan baanopeningen door de vervangingvraag. Deze vervangingsbehoefte ontstaat door het vertrek van personeel vanwege - al dan niet vervroegde - pensionering, arbeidsongeschiktheid, tijdelijke terugtreding van de arbeidsmarkt, beroepsmobiliteit, e.d.. Er wordt overigens alleen van vervangingsvraag gesproken voor zover het vertrek van een werknemer ook daadwerkelijk leidt tot een vacature voor een nieuwkomer. Als het vertrek van een arbeidskracht gebruikt wordt om een werkgelegenheidskrimp te realiseren, is er derhalve geen sprake van vervangingsvraag. Deze arbeidsmarktuitstroom is in dat geval immers niet relevant voor nieuwkomers. Dit betekent dat niet de volledige arbeidsmarktuitstroom daadwerkelijk leidt tot vervangingsvraag.

Bovendien is er een belangrijk verschil tussen de vervangingsvraag per beroepsgroep en per opleidingstype. De beroepsmobiliteit is namelijk wel van invloed op de vervangingsvraag per beroepsgroep, maar heeft geen effect op de vervangingsvraag per opleidingstype. Het veranderen van beroep heeft immers geen gevolgen voor de opleidingenstructuur van de werkgelegenheid. Daarentegen kan het afronden van een vervolgopleiding naast een baan betekenen dat een werkende in feite uitstroomt naar een ander opleidingstype. In dat geval is er sprake van een vervangingsvraag bij het opleidingstype waartoe de vooropleiding van deze werkende wordt gerekend.

Aangezien gedetailleerde stroomcijfers over de mobiliteit onvoldoende beschikbaar zijn, worden met behulp van standcijfers geslachts- en leeftijdsspecifieke netto verloopcoëfficiënten bepaald. Deze worden vervolgens gerelateerd aan de leeftijdsopbouw van de werkenden per beroepsgroep en opleidingstype. Evenals bij de uitbreidingsvraag wordt bij de vervangingsvraagprognose niet op regionaal niveau een specifieke analyse gemaakt van de verloopcoëfficiënten. De verwachte landelijke coëfficiënten worden geprojecteerd op de geslachts- en leeftijdsopbouw van de regionale werkgelegenheid. Op deze wijze wordt er dus expliciet rekening gehouden met de feitelijke leeftijdsopbouw van de werkenden per beroepsgroep en opleidingstype in Limburg.

Bij een toename van de werkgelegenheid vormen de uitbreidingsvraag en de vervangingsvraag tezamen het aantal baanopeningen voor nieuwkomers op de arbeidsmarkt. Bij krimpende werkgelegenheid kan er alleen sprake zijn van baanopeningen vanwege de vervangingvraag. Het aantal baanopeningen kan overigens verschillen van het aantal vacatures. Het belangrijkste verschil wordt veroorzaakt door de zogenaamde baanbaan-mobiliteit van werkenden. Deze baan-baan-mobiliteit op de externe of de bedrijfsinterne arbeidsmarkt leidt immers tot vacatureketens die niet tot uiting komen in de baanopeningen voor nieuwkomers (zie ook paragraaf 2.5). Deze baan-baan-mobiliteit levert 
immers geen nieuwe banen op voor nieuwkomers op de arbeidsmarkt.

Tegenover de totale vraag naar nieuwkomers staat het verwachte aanbod van nieuwkomers, bestaande uit de toekomstige instroom van schoolverlaters in de prognoseperiode en het aan het begin van de prognoseperiode nog boven de markt zwevende aanbod van nietwerkende werkzoekenden met een kleine afstand tot de arbeidsmarkt. De afstand tot de arbeidsmarkt wordt bepaald met behulp van het faseringsmodel van Arbeidsvoorziening. Werkzoekenden in fase 1 worden als direct bemiddelbaar beschouwd. Daarentegen wordt verondersteld dat werkzoekenden in fase 2 en hoger op dit moment geen serieuze concurrenten vormen voor schoolverlaters. De prognoses van de instroom van schoolverlaters zijn in belangrijke mate gebaseerd op de Referentieraming 1997 van het Ministerie van Onderwijs, Cultuur en Wetenschappen. Door het ROA zijn deze prognoses nader verbijzonderd en aangevuld met prognoses van de doorstroom naar het niet-reguliere onderwijs.

Door de verwachte vraag- en aanbodstromen met elkaar te confronteren wordt per opleidingstype een indicatie verkregen van de toekomstige arbeidsmarktperspectieven voor nieuwkomers op de arbeidsmarkt. De betreffende indicator geeft aan welke vraag-aanboddiscrepantie er per opleidingstype te verwachten is. Een aanbodoverschot impliceert echter niet vanzelfsprekend dat de betreffende groep werkloos zal blijven of worden en een aanbodtekort betekent niet automatisch dat er sprake zal zijn van openstaande vacatures. In de praktijk blijkt dat werkgevers bij een overschot aan hoger opgeleiden hun eisen aanpassen en mensen aannemen met een hogere opleidingachtergrond dan aanvankelijk gevraagd werd. Voor degenen met een opleiding waarvoor het aanbod de vraag overtreft, betekent dit dat zij vaker beneden hun niveau moeten werken, een minder goed contract krijgen, slechter beloond worden of vaker genoegen nemen met part-time werk, terwijl men liever een full-time betrekking had. Omgekeerd zal bij een tekortschietend aanbod de positie van degenen met de betreffende achtergrond verbeteren. Zij hoeven in dat geval geen genoegen te nemen met een functie op een lager niveau, een lagere beloning, e.d..

De vraag-aanbod-confrontatie geeft voor elk opleidingstype ook een indicatie van de toekomstige knelpunten in de personeelsvoorziening van dat type. Daarbij bepalen de uitbreidings- en vervangingsvraag, tezamen met de openstaande vacatures, de rekruteringsbehoefte per opleidingstype. Bij krimpende werkgelegenheid voor een bepaald opleidingstype wordt deze rekruteringsbehoefte op een andere wijze berekend dan het aantal baanopeningen voor nieuwkomers op de arbeidsmarkt, omdat er vanuit het perspectief van de werkgevers de mogelijkheid bestaat de rekruteringsbehoefte te verkleinen door de gedwongen uitstroom van zittend personeel te verminderen. Zeker wanneer werkgevers geconfronteerd worden met een krappe arbeidsmarkt voor een bepaald 
opleidingstype, zullen zij van deze mogelijkheid gebruik maken ${ }^{48}$.

\subsection{Uitbreidingsvraag}

\section{Beroepen}

Door de uiteenlopende werkgelegenheidsontwikkelingen in de diverse bedrijfssectoren en de verschuivingen in de beroepenstructuur binnen de bedrijfssectoren, zijn er grote verschillen in de verwachte uitbreidingsvraag in 1998 tussen de diverse beroepsgroepen.

Tabel 3.1

Beroepsgroepen met relatief de hoogste uitbreidingsvraag in Limburg in 1998 (percentage van de werkgelegenheid)

$\begin{array}{llll}\text { Beroepsgroep } & \% & \text { typering }\end{array}$

Productieplanners

Kantoorhulpen, inpakkers en colporteurs

Ziekenverzorgenden

Boekhouders en secretaresses

Systeemanalisten

Activiteitenbegeleiders en medew. arbeidsbemiddeling

Agrarische arbeiders

Programmeurs
10,9

6,8

5,6

4,9

4,8

4,8

3,8

3,7
erg hoog
erg hoog
erg hoog
erg hoog
erg hoog
erg hoog
hoog
hoog

Bron: ROA

Tabel 3.1 geeft een overzicht van de beroepsgroepen met de hoogste relatieve uitbreidingsvraag, dat wil zeggen: de hoogste uitbreidingsvraag in verhouding tot de werkgelegenheid in de betreffende beroepsgroep ${ }^{49}$. De tabel laat een divers beeld zien. De tabel bevat beroepsgroepen in verschillende richtingen en op verschillende niveaus. De uitbreidingsvraag is het hoogst voor de beroepsgroep productieplanners. Hier ligt met name de sterke verwachte groei in de werkgelegenheid in de metaalsector aan ten grondslag. Opvallend is tevens de groei in de automatiseringsberoepen systeemanalisten en programmeurs.

48. Opgemerkt dient te worden dat in het prognosemodel vooralsnog geen rekening is gehouden met (internationale) pendel.

49. Opgemerkt dient te worden dat in de in dit hoofdstuk gepresenteerde tabellen alleen beroepsgroepen en opleidingstypen zijn opgenomen waarin meer dan 2.000 mensen werkzaam zijn. Voor de kleinere beroepsgroepen en opleidingstypen worden, in het licht van de betrouwbaarheid, alleen kwalitatieve typeringen van de prognoses gepresenteerd. Zie voor een volledig overzicht hoofdstuk 5 van de Statistische Bijlage. 
Tabel 3.2

Beroepsgroepen met relatief de laagste uitbreidingsvraag in Limburg in 1998 (percentage van de werkgelegenheid)

Beroepsgroep $\quad \% \quad$ typering

Politie-agenten, onderofficieren en beveiligingsemp.

$-2,2 \quad$ erg laag

Docenten exacte, med. en verz. vakken (2e graads) $\quad-1,8 \quad$ erg laag

Docenten talen en expressie

$-1,5 \quad$ erg laag

Receptionisten en administratieve employés

$-1,2 \quad$ erg laag

Agrarische bedrijfshoofden

$-0,9 \quad$ erg laag

Juridisch en fiscaal medewerkers

$-0,9 \quad$ erg laag

Leraar basisonderwijs

$-0,3 \quad$ laag

Mechanisch operators

$-0,2 \quad$ laag

Bron: ROA

Tabel 3.2 geeft een overzicht van de beroepsgroepen die in 1998 zullen krimpen. Opmerkelijk is dat drie van de acht beroepen onderwijsberoepen zijn. De dalende werkgelegenheid in het onderwijs ligt hieraan ten grondslag. De ontgroening en de ombuigingen in het onderwijs zouden hierbij een belangrijke rol kunnen spelen. Daarnaast kunnen veranderende opleidings- en vakkenpakketkeuzes van leerlingen ten grondslag liggen aan de krimp in de vraag naar docenten in specifieke richtingen. Ook landelijk is dit beeld zichtbaar. De grootste krimp wordt overigens verwacht bij politie-agenten, onderofficieren en beveiligingsemployés. Hier liggen de ombuigingen bij het leger aan ten grondslag. Overigens dient opgemerkt te worden dat de tabel hiermee opvallend veel beroepsgroepen bevat waarvoor de werkgelegenheid erg gevoelig is voor veranderingen in het overheidsbeleid ${ }^{50}$.

\section{Opleidingen}

Tabel 3.3 laat zien voor welke opleidingstypen relatief de grootste uitbreidingsvraag verwacht wordt in 1998. Opmerkelijk is dat de in de tabel genoemde opleidingstypen op $\mathrm{MBO} /$ Leerlingwezen-niveau of hoger zijn. De grootste groei zal zich naar verwachting voordoen bij WO econom(etr)ie. De uitbreidingsvraag voor dit opleidingstype is 7,8 procent van de huidige werkgelegenheid voor dit opleidingstype. Op MBO/Leerlingwezen-niveau zijn het vooral technisch georiënteerde richtingen die een sterke groei laten zien. Daarnaast is er sprake van een hoge verwachte uitbreidingsvraag voor de richtingen milieu en groene ruimte en horeca.

50. Bij de prognose voor leraar basisonderwijs is bijvoorbeeld geen rekening gehouden met een eventuele verkleining van de klassen. 
Tabel 3.3

Opleidingstypen met relatief de hoogste uitbreidingsvraag in Limburg in 1998 (percentage van de werkgelegenheid)

\begin{tabular}{lll} 
Opleidingstype & $\%$ & typering \\
\hline WO econom(etr)ie & 7,8 & erg hoog \\
MBO/LLW milieu en groene ruimte & 7,5 & erg hoog \\
MBO/LLW procestechniek & 5,2 & hoog \\
HBO (fysio)therapie & 5,0 & hoog \\
MBO/LLW motorvoertuigentechniek & 4,6 & hoog \\
MBO/LLW vervoer & 4,6 & hoog \\
MBO sociaal-cultureel & 4,6 & hoog \\
MBO/LLW bouw & 4,5 & hoog \\
MBO/LLW horeca & 4,5 & hoog
\end{tabular}

Bron: ROA

In tabel 3.4 wordt een overzicht gegeven van de opleidingstypen waarvoor verhoudingsgewijs de grootste krimp wordt verwacht. Voor degenen die alleen Basisonderwijs hebben gevolgd, daalt de werkgelegenheid met ruim 5\%. Enerzijds daalt het aantal banen voor ongeschoolden steeds verder; anderzijds worden ook voor de lagere banen steeds hogere eisen gesteld. Het grote aantal VBO-opleidingen in de tabel illustreert de upgrading. De upgrading is in belangrijke mate het gevolg van de functie-eisen in veel beroepen, waardoor MBO'ers de plaats innemen van VBO'ers. Een goed voorbeeld hiervan is de opleiding motorvoertuigentechniek. Terwijl deze opleiding op MBO/Leerlingwezen-niveau tot de sterkste groeiers behoort, zoals tabel 3.3 laat zien, wordt voor deze opleiding op VBOniveau een krimp van 1,1 procent verwacht. Het verschijnsel dat de werkgelegenheid voor de lagere beroepen veel minder vaak een dalende tendens vertoont vergeleken met de lagere opleidingen kan verklaard worden uit het feit dat het upgradingsproces zich vooral binnen beroepen voordoet. 
Tabel 3.4

Opleidingstypen met relatief de laagste uitbreidingsvraag in Limburg in 1998 (percentage van de werkgelegenheid)

Opleidingstype $\quad \% \quad$ typering

\section{Basisonderwijs}

VBO administratie, handel en textiel

WO wiskunde en natuurwetenschappen

VBO landbouw en natuurlijke omgeving

VBO mechanische techniek

HBO lerarenopleiding talen

MBO/LLW geld, bank en belastingen

VBO motorvoertuigentechniek

$\begin{array}{ll}-5,2 & \text { erg laag } \\ -2,6 & \text { erg laag } \\ -2,1 & \text { erg laag } \\ -1,8 & \text { laag } \\ -1,8 & \text { laag } \\ -1,6 & \text { laag } \\ -1,4 & \text { laag } \\ -1,1 & \text { laag }\end{array}$

Bron: ROA

\subsection{Vervangingsvraag}

\section{Beroepen}

Vervangingsvraag is de vraag naar nieuwe arbeidskrachten die ontstaat doordat er arbeidsplaatsen vrijkomen van werkenden, die met pensioen gaan, die arbeidsongeschikt worden of die zich terugtrekken van de arbeidsmarkt. De vervangingsvraag per beroepsgroep wordt bovendien beïnvloed door de arbeidsmobiliteit van werkenden.

In tabel 3.5 wordt een overzicht gegeven van de beroepsgroepen waarvoor in 1998 relatief de grootste vervangingsvraag wordt verwacht. De tabel bevat twee docentenberoepen. De vergrijzing onder de leraren speelt daarbij een belangrijke rol. Dit benadrukt tevens dat de in tabel 3.2 gesignaleerde krimp in de werkgelegenheid voor docenten niet noodzakelijkerwijs betekent dat de baanopeningen voor leraren zullen afnemen. Ook aan de grote vervangingsvraag bij de café- en snackbarhouders en de conciërges ligt de grote uitstroom van ouderen ten grondslag. Bij de beroepsgroepen receptionisten en administratieve employés, hulpkrachten horeca en verzorging en verkopers, waarin relatief veel jongeren werkzaam zijn, speelt de arbeidsmobiliteit een relatief grote rol. 


\section{Tabel 3.5}

Beroepsgroepen met relatief de hoogste vervangingsvraag in Limburg in 1998 (percentage van de werkgelegenheid)

\begin{tabular}{lll} 
Beroepsgroep & $\%$ & typering \\
\hline Docenten landbouw en techniek (2e graads) & 8,8 & erg hoog \\
Managers & 8,5 & erg hoog \\
Café- en snackbarhouders & 8,2 & erg hoog \\
Conciërges & 6,8 & erg hoog \\
Docenten talen en expressie & 6,5 & erg hoog \\
Receptionisten en administratieve employés & 6,1 & erg hoog \\
Hulpkrachten horeca en verzorging & 5,9 & erg hoog \\
Verkopers & 5,2 & erg hoog \\
\hline
\end{tabular}

Bron: ROA

Tabel 3.6

Beroepsgroepen met relatief de laagste vervangingsvraag in Limburg in 1998 (percentage van de werkgelegenheid)

\begin{tabular}{lll}
\hline Beroepsgroep & $\%$ & typering \\
\hline & & \\
Programmeurs & 1,2 & erg laag \\
Activiteitenbegeleiders en medew. arbeidsbemiddeling & 1,9 & erg laag \\
Laders en lossers & 2,0 & erg laag \\
Sociaal-cultureel werkers & 2,0 & erg laag \\
Verzorgend personeel & 2,1 & erg laag \\
Boekhouders en secretaresses & 2,3 & laag \\
Systeemanalisten & 2,3 & laag \\
Assistent accountants & 2,4 & laag \\
\hline
\end{tabular}

Bron :ROA

Tabel 3.6 geeft een beeld van de beroepsgroepen met een relatief lage vervangingsvraag. Enerzijds bevat de tabel sterk groeiende beroepsgroepen, zoals programmeurs en systeemanalisten. De werkenden in deze beroepsgroepen zijn daardoor relatief jong en de beroepsmobiliteit is laag. Anderzijds worden beroepsgroepen die van oudsher gekenmerkt worden door een lage gemiddelde leeftijd van de werkenden zoals boekhouders en secretaresses en verzorgend personeel, gekenmerkt door een verhoudingsgewijs lage vervangingsvraag.

\section{Opleidingen}

In tabel 3.7 worden de opleidingstypen met relatief de grootste verwachte vervangingsvraag in 1998 weergegeven. Opvallend is opnieuw het feit dat de tabel een aantal lerarenopleidingen bevat. Zoals hierboven reeds aangegeven, speelt de vergrijzing bij de 
werkzame leraren hierbij een belangrijke rol. Ook de relatief hoge vervangingsvraag voor WO wiskunde en natuurwetenschappen wordt veroorzaakt door het feit dat veel werkenden met deze opleidingsachtergrond in het onderwijs werkzaam zijn. MBO/LLW bedrijfskunde en WO (dier)geneeskunde zijn opleidingstypen waarin het aandeel van jongeren laag is. Aangezien jongeren verhoudingsgewijs een lage uitstroom kennen, worden deze opleidingstypen gekenmerkt door een relatief hoge vervangingsvraag.

\section{Tabel 3.7}

Opleidingstypen met relatief de hoogste vervangingsvraag in Limburg in 1998 (percentage van de werkgelegenheid)

$\begin{array}{lll}\text { Opleidingstype } & \% & \text { typering }\end{array}$

WO wiskunde en natuurwetenschappen

6,2 erg hoog

HBO lerarenopleiding expressie

$5,1 \quad$ erg hoog

$\mathrm{HBO}$ lerarenopleiding talen

$4,8 \quad$ erg hoog

MBO/LLW bedrijfskunde

$4,6 \quad$ erg hoog

WO (dier-)geneeskunde

4,2 hoog

$\mathrm{MBO} / \mathrm{LLW}$ landbouw en veeteelt

$4,1 \quad$ hoog

$\mathrm{HBO}$ werktuigbouwkunde

4,1

hoog

$\mathrm{HBO}$ lerarenopleiding natuur en techniek

4,0

gemiddeld

\section{Bron: ROA}

Tabel 3.8 geeft een overzicht van de opleidingstypen die naar verwachting gekenmerkt worden door een relatief lage vervangingsvraag in 1998. Net als bij de beroepsgroepen speelt een snelle groei van de werkgelegenheid hierbij een rol, zoals bij HBO informatica. Deze snelle groei heeft geleid tot een relatief lage gemiddelde leeftijd van de werkenden met deze opleidingsachtergrond, wat leidt tot een lage uitstroom. Ook bij de andere in deze tabel genoemde opleidingstypen wordt de lage vervangingsvraag met name veroorzaakt door een lage uitstroom als gevolg van een lage gemiddelde leeftijd van de werkenden. Een uitzondering vormt HBO verpleegkunde. Ook gezien het hoge percentage vrouwen is de lage verwachte vervangingsvraag voor dit opleidingstype opmerkelijk. 
Tabel 3.8

Opleidingstypen met relatief de laagste vervangingsvraag in Limburg in 1998 (percentage van de werkgelegenheid)

Opleidingstype $\quad \% \quad$ typering

VBO administratie, handel en textiel $\quad 0,8 \quad$ erg laag

MBO/LLW horeca $\quad 1,5$ erg laag

HAVO/NWO

MBO/LLW milieu en groene ruimte $\quad 1,9 \quad$ erg laag

MBO/LLW verzorging $\quad 2,1 \quad$ erg laag

$\mathrm{MBO} / \mathrm{LLW}$ secretariaat $\quad 2,1 \quad$ erg laag

HBO informatica $\quad 2,1 \quad$ erg laag

$\mathrm{HBO}$ verpleegkunde $\quad 2,1 \quad$ erg laag

Bron: ROA

\subsection{Baanopeningen}

\section{Beroepen}

De (positieve) uitbreidingsvraag en de vervangingsvraag vormen tezamen het aantal baanopeningen voor nieuwkomers op de arbeidsmarkt. In tabel 3.9 wordt een overzicht gegeven van de beroepsgroepen waarvoor het aantal baanopeningen verhoudingsgewijs het grootst is. De tabel bevat enerzijds beroepsgroepen waarbij de uitbreidingsvraag hoog is, zoals productieplanners, kantoorhulpen, inpakkers en colporteurs en ziekenverzorgenden (zie tabel 3.1). Daarentegen worden de baanopeningen voor de beroepsgroepen hulpkrachten horeca en verzorging, docenten landbouw en techniek, café- en snackbarhouders, conciërges en managers met name door een relatief hoge vervangingsvraag veroorzaakt (zie tabel 3.5).

Het NEI heeft recentelijk vacatureprognoses naar RBA-gebied gemaakt voor $1998^{51}$. Hoewel baanopeningen en vacatures niet geheel vergelijkbare concepten zijn en het aantal vacatures door baan-baan-mobiliteit binnen beroepsgroepen en zogenaamde 'vacatureketens' veel hoger uitvalt dan het aantal baanopeningen voor nieuwkomers ${ }^{52}$ levert een vergelijking van beide prognoses waardevolle informatie over de te verwachten ontwikkelingen in 1998 per beroep. In tabel 3.10a wordt een overzicht gegeven van de beroepsgroepen waarvoor het ROA absoluut gezien het hoogste aantal baanopeningen verwacht in 1998. Tabel 3.10b geeft aan welke beroepen volgens het NEI het grootste aantal

51. NEI, Regionale prognoses NWW-bestand en vacaturemarkt, Rotterdam, 1997.

52. A. de Grip, P. Meyboom en E. Willems, 'Vacatures, Werkgelegenheidsontwikkeling en de vraag naar nieuwkomers op de arbeidsmarkt', in: Tijdschrift voor Politieke Economie, 18 e jaargang nr. 1, 1995, pp. 36-57. 
vacatures zullen kennen in 1998. De tabellen laten een groot aantal overeenkomsten zien. De verkopers, boekhouders, hulpkrachten horeca en verzorging, bouwvakkers, interieurverzorgers en een aantal administratieve functies zijn in beide tabellen terug te vinden. Er zijn echter ook een aantal opvallende verschillen. De chauffeurs zijn niet in de $\mathrm{NEI}$-tabel terug te vinden. De architecten, e.d., de leerkrachten en het cluster van medische beroepen zijn niet in de ROA-tabel terug te vinden. Deze verschillen kunnen zowel conceptuele als praktische oorzaken hebben. Ten eerste is er, zoals reeds opgemerkt in de inleiding van dit hoofdstuk, een verschil tussen 'baanopeningen' en 'vacatures'. Ten tweede zijn er verschillen in de gehanteerde classificaties. Zo worden door het ROA de leerkrachten en de medische beroepen verder uitgesplitst, waardoor zij niet in de ROA-tabel 3.10a terug te vinden zijn.

\section{Tabel 3.9}

Beroepsgroepen met relatief het hoogste aantal baanopeningen in Limburg in 1998 (percentage van de werkgelegenheid)

\begin{tabular}{lcc} 
Beroepsgroep & $\%$ & typering \\
\hline & & \\
Productieplanners & 10,7 & erg hoog \\
Café- en snackbarhouders & 10,4 & erg hoog \\
Conciërges & 10,3 & erg hoog \\
Managers & 9,7 & erg hoog \\
Docenten landbouw en techniek (2e graads) & 9,3 & erg hoog \\
Kantoorhulpen, inpakkers en colporteurs & 9,3 & erg hoog \\
Ziekenverzorgenden & 8,9 & erg hoog \\
Hulpkrachten horeca en verzorging & 8,7 & erg hoog \\
\hline
\end{tabular}

Bron: ROA

Tabel 3.10a

Beroepsgroepen met absoluut het hoogste aantal baanopeningen in Limburg in 1998

Beroepsgroep

aantal

baanopeningen

Boekhouders en secretaresses

Chauffeurs

1.400

Verkopers

1.200

Hulpkrachten horeca en verzorging

1.000

Receptionisten en administratieve employés $\quad 900$

Commercieel employés

800

Interieurverzorgers $\quad 800$

Bouwvakkers $\quad 700$

Commercieel medewerkers $\quad 600$

Agrarische arbeiders $\quad 500$

Bron: ROA 
Tabel $3.10 b$

Beroepen met absoluut het hoogste aantal verwachte aantal vacatures in het RBA-gebied Limburg in 1998

Beroep aantal

vacatures

Winkelbedienden e.a. verkopers

4.282

Koks, kelners, buffetbedienden, e.d.

3.526

Overige administratieve functies

3.457

Boekhouders, cassiers, e.d.

3.298

Agrarische arbeiders

2.221

Genees- en tandheelkundigen, dierenartsen, verplegenden, e.d.

1.974

Architecten/ingenieurs en verwante technici/tekenaars

1.964

Metselaars, timmerlieden e.a. bouwvakkers

1.813

Leerkrachten

1.782

Huisbewaarders, schoonmaakpersoneel

1.640

Bron: NEI

Ook is het interessant te kijken naar de verhouding tussen de verwachte vacatures en de baanopeningen. Zo is het aantal vacatures voor agrarische arbeiders ruim vier keer zo groot als het aantal baanopeningen, terwijl bij de interieurverzorgers het aantal vacatures twee maal zo groot is. Mogelijk is dit verschil het gevolg van het sterk tijdelijke karakter van veel vacatures voor agrarische arbeiders.

Tabel 3.11, waarin een overzicht wordt gegeven van de beroepsgroepen met relatief het laagste aantal verwachte baanopeningen in 1998, kent opvallend weinig beroepsgroepen die gekenmerkt worden door een lage uitbreidingsvraag of door een lage vervangingsvraag. Dit geldt alleen voor de laders en lossers, waarvoor een lage vervangingsvraag verwacht wordt (zie tabel 3.6) en voor de productiemedewerkers en de politie-agenten, onderofficieren en beveiligingshulpkrachten, waarvoor een krimpende werkgelegenheid wordt verwacht (zie tabel 3.2). Er zijn verschillende oorzaken aan te wijzen voor het feit dat tabel 3.11 slechts weinig beroepsgroepen bevat die gekenmerkt worden door een lage uitbreidings- of vervangingsvraag. Ten eerste worden, zoals tabel 3.2 liet zien, de krimpberoepen gedomineerd door beroepen in het onderwijs. Deze beroepen worden echter tevens gekenmerkt door een hoge vervangingsvraag. Ten tweede hangt een lage vervangingsvraag vaak samen met een snelle groei van de werkgelegenheid waardoor de werkenden in deze beroepen relatief jong zijn en de uitstroom dus laag. Voorbeelden hiervan vormen de automatiseringsberoepen, zoals programmeurs en systeemanalisten. 
Tabel 3.11

Beroepsgroepen met relatief het laagste aantal baanopeningen in Limburg in 1998 (in procenten van de werkgelegenheid)

\begin{tabular}{lll} 
Beroepsgroep & $\%$ & typering \\
\hline & & \\
Laders en lossers & 2,8 & laag \\
Productiemedewerkers & 2,9 & laag \\
Politie-agenten, onderofficieren en beveiligingshulpkr. & 3,0 & laag \\
Monteurs & 3,3 & laag \\
Mechanisch operators & 3,7 & gemiddeld \\
Procesoperators & 3,7 & gemiddeld \\
Winkeliers & 3,7 & gemiddeld \\
Aannemers en installateurs & 3,9 & gemiddeld \\
\hline
\end{tabular}

Bron: ROA

\section{Opleidingen}

Tabel 3.12 laat zien voor welke opleidingstypen het aantal baanopeningen in 1998 verhoudingsgewijs het hoogst zal zijn. Het is opmerkelijk dat de MBO/Leerlingwezenopleidingen deze tabel domineren. De tabel bevat geen enkel opleidingstype op VBOniveau. De tabel wordt gedomineerd door opleidingstypen die gekenmerkt worden door een relatief hoge verwachte uitbreidingsvraag (zie tabel 3.3). Een uitzondering vormt MBO/LLW landbouw en veeteelt, waarvoor vooral de hoge vervangingsvraag ten grondslag ligt aan het relatief hoge aantal baanopeningen. Twee redenen zouden ten grondslag kunnen liggen aan het feit dat opleidingstypen met een hoge verwachte uitbreidingsvraag het beeld bepalen. Uit tabel 3.7 bleek dat met name onderwijsopleidingen gekenmerkt worden door een hoge vervangingsvraag. Deze opleidingen worden echter, zoals gezegd, tevens gekenmerkt door een relatief lage uitbreidingsvraag, waardoor het totale aantal baanopeningen lager uitvalt. Ten tweede zijn, gemiddeld genomen, de verschillen in de vervangingsvraag veel minder groot dan de verschillen in de uitbreidingsvraag, waardoor met name de relatieve omvang van de uitbreidingsvraag de rangorde bepaald. 
Tabel 3.12

Opleidingstypen met relatief het hoogste aantal baanopeningen in Limburg in 1998 (percentage van de werkgelegenheid)
Opleidingstype
$\%$
typering

WO econom(etr)ie

$\mathrm{MBO} / \mathrm{LLW}$ milieu en groene ruimte

MBO/LLW vervoer

HBO (fysio-)therapie

MBO/LLW motorvoertuigentechniek

MBO/LLW procestechniek

MBO/LLW bouw

$\mathrm{MBO} / \mathrm{LLW}$ landbouw en veeteelt
$9,8 \quad$ erg hoog

9,4 erg hoog

8,5 hoog

7,9 hoog

$7,7 \quad$ hoog

7,5 gemiddeld

$7,4 \quad$ gemiddeld

7,4 gemiddeld

\section{Bron: ROA}

Tabel 3.13 brengt de opleidingstypen met relatief gezien het laagste aantal baanopeningen in 1998 in beeld. Een verhoudingsgewijs klein aantal baanopeningen blijkt vooral bij opleidingstypen op VBO-niveau voor te komen. Over het algemeen zijn dit opleidingstypen met een lage uitbreidingsvraag of zelfs een krimpende werkgelegenheid, vanwege de upgrading van de opleidingseisen in diverse beroepsgroepen. De andere opleidingen in de tabel - MBO/LLW verzorging en HBO elektrotechniek - worden met name gekenmerkt door een lage vervangingsvraag.

Tabel 3.13

Opleidingstypen met relatief het laagste aantal baanopeningen in Limburg in 1998 (percentage van de werkgelegenheid)

\begin{tabular}{lll} 
Opleidingstype & $\%$ & typering \\
\hline VBO administratie, handel en techniek & & \\
MBO/LLW verzorging & 0,8 & erg laag \\
VBO landbouw en natuurlijke omgeving & 2,2 & erg laag \\
VBO horeca en levensmiddelentechniek & 2,3 & laag \\
VBO elektrotechniek & 2,3 & laag \\
VBO bouwtechniek & 2,5 & laag \\
VBO vervoer & 2,7 & laag \\
HBO elektrotechniek & 2,8 & laag \\
\end{tabular}

Bron: ROA

\subsection{Instroom van schoolverlaters op de arbeidsmarkt}

De baanopeningen geven een indicatie van de ontwikkelingen aan de vraagzijde van de arbeidsmarkt. Om een beeld te kunnen vormen van de toekomstige arbeidsmarktsituatie moeten ook de aanbodontwikkelingen in beeld worden gebracht. Naast het aan het begin 
van de prognoseperiode, aantal direct bemiddelbare niet-werkende werkzoekenden gaat het hierbij vooral om de verwachte arbeidsmarktinstroom van schoolverlaters in 1998.

Tussen de verschillende opleidingstypen zijn er aanzienlijke verschillen in de verwachte arbeidsmarktinstroom van schoolverlaters. Tabel 3.14 geeft een overzicht van de opleidingstypen waarvoor de verwachte arbeidsmarktinstroom in 1998 verhoudingsgewijs het grootst is ${ }^{53}$. Drie factoren spelen hierbij een rol: de populariteit van de opleidingen bij de studiekeuze, het aantal werkenden met de betreffende opleidingsachtergrond en de mate waarin de opleiding het eindpunt vormt van de (initiële) opleiding. Relatief de grootste arbeidsmarktinstroom wordt verwacht vanuit het HAVO en VWO. Hieraan ligt met name het relatief lage aantal werkenden met deze opleidingsachtergrond ten grondslag. Dit is vooral het gevolg van het feit dat veel werkenden met deze opleidingsachtergrond door het volgen van niet-initiële opleidingen een andere opleidingsachtergrond krijgen. Opvallend is het grote aantal lage opleidingen in de tabel. Deze opleidingen worden blijkbaar niet alleen vaak gekozen; een groot deel van de schoolverlaters van deze opleidingen stroomt blijkbaar niet door naar een vervolgopleiding of naar het Leerlingwezen, maar is direct beschikbaar voor de arbeidsmarkt.

Tabel 3.14

Opleidingstypen met relatief de grootste arbeidsmarktinstroom van schoolverlaters in Limburg in 1998 (percentage van de werkgelegenheid)

$\begin{array}{lll}\text { Opleidingstype } & \% & \text { typering }\end{array}$

$\begin{array}{lll}\text { HAVO/VWO } & 7,8 & \text { erg hoog } \\ \text { MBO sociaal-cultureel } & 7,7 & \text { erg hoog } \\ \text { VBO administratie, handel en textiel } & 5,6 & \text { hoog } \\ \text { Basisonderwijs } & 4,7 & \text { hoog } \\ \text { VBO motorvoertuigentechniek } & 4,6 & \text { hoog } \\ \text { VBO horeca en levensmiddelentechniek } & 4,2 & \text { hoog } \\ \text { MBO/LLW secretariaat } & 3,6 & \text { gemiddeld } \\ \text { MBO/LLW uiterlijke verzorging } & 3,5 & \text { gemiddeld }\end{array}$

Bron: ROA

\subsection{Knelpunten in de personeelsvoorziening in 1998}

Op basis van de in dit hoofdstuk geschetste verwachte ontwikkelingen aan de vraag- en de aanbodzijde van de arbeidsmarkt, kan een indicatie worden gegeven van de te verwachten knelpunten in de personeelsvoorziening voor werkgevers, verbijzonderd naar opleidingstype. De uitspraken op dit punt zijn gebaseerd op de Indicator Toekomstige Knelpunten in de Personeelsvoorziening (ITKP) die voor elk opleidingstype de verhouding weergeeft tussen

53. Zoals reeds eerder opgemerkt worden alleen voor het Basisonderwijs, de VBOopleidingen en de MBO/Leerlingwezen-opleidingen regionale prognoses gepresenteerd. 
arbeidsaanbod en -vraag. Wanneer het aanbod kleiner is dan de vraag en de ITKP dus kleiner is dan 1,00, dan worden de knelpunten in de personeelsvoorziening als groot getypeerd. Als de waarde zelfs kleiner is dan 0,85 dan wordt gesproken van zeer grote knelpunten. Wanneer de ITKP daarentegen groter is dan 1,00, maar kleiner dan 1,05 wordt gesproken van enige knelpunten. Bij een hogere waarde van de ITKP wordt gesproken van vrijwel geen knelpunten, of als de ITKP zelfs groter is dan 1,15 van geen knelpunten in de personeelsvoorziening.

\section{Opleidingen met grote knelpunten in de personeelsvoorziening}

Door enerzijds de ontgroening en de vergrijzing en anderzijds de relatief gunstige verwachte economische ontwikkelingen, worden er voor een groot aantal opleidingtypen grote knelpunten in de personeelsvoorziening verwacht in 1998. Voor maar liefst 27 van de 52 onderscheiden opleidingstypen worden grote knelpunten verwacht ${ }^{54}$. Dit geldt met name op MBO/Leerlingwezen-niveau, waar er voor 25 van de 32 opleidingen sprake zal zijn van een tekort aan direct inzetbare werkzoekenden. De upgrading van de opleidingseisen in verschillende beroepsgroepen speelt hierbij een belangrijke rol. Dit beeld wordt weerspiegeld in tabel 3.15, waarin een overzicht wordt gegeven van de opleidingstypen waarvoor de grootste knelpunten worden verwacht. De tabel laat zien dat het hier uitsluitend om opleidingen op MBO/Leerlingwezen-niveau gaat. De grootste knelpunten worden verwacht voor het opleidingstype procestechniek. Aan het tekort aan direct inzetbaar aanbod voor dit opleidingstype ligt met name de hoge uitbreidingsvraag ten grondslag. Ook bij de opleidingen motorvoertuigentechniek, bouw, vervoer en horeca is met name de hoge uitbreidingsvraag verantwoordelijk voor de grote knelpunten. Voor de opleiding bedrijfskunde wordt daarentegen vooral een relatief hoge vervangingsvraag verwacht.

54. Gezien het feit dat er voor de HBO- en WO-opleidingen, mede als gevolg van de hoge regionale mobiliteit, geen betrouwbare regionale gegevens over de arbeidsmarktinstroom van schoolverlaters beschikbaar zijn, worden er geen regionale prognoses over de knelpunten op de korte termijn voor deze hogere opleidingen gepresenteerd. 
Tabel 3.15

Opleidingstypen met de grootste knelpunten in de personeelsvoorziening in Limburg in 1998

\begin{tabular}{lll} 
Opleidingstype & ITKP & typering \\
\hline & & \\
MBO/LLW procestechniek & 0,94 & groot \\
MBO/LLW vervoer & 0,94 & groot \\
MBO/LLW bedrijfskunde & 0,94 & groot \\
MBO/LLW motorvoertuigentechniek & 0,95 & groot \\
MBO/LLW bouw & 0,96 & groot \\
MBO/LLW verpleging & 0,96 & groot \\
MBO/LLW landbouw en veeteelt & 0,97 & groot \\
MBO/LLW horeca & 0,98 & groot
\end{tabular}

Bron: ROA

Wanneer er voor een opleiding grote knelpunten in de personeelsvoorzienig verwacht worden, dan is het voor werkgevers moeilijk een geschikte kandidaat te vinden die een opleidingsachtergrond heeft die goed aansluit bij de functie-eisen. Dit betekent echter dat de arbeidsmarktperspectieven voor schoolverlaters met deze opleiding over het algemeen goed tot zeer goed zijn. Grote knelpunten impliceren immers een aanbodtekort en daarmee een relatief grote kans op het vinden van een baan op een niveau en in een richting waarop men toen men aan de opleiding begon zou mogen rekenen.

\section{Opleidingen met (vrijwel) geen knelpunten in de personeelsvoorziening}

Ondanks de voortzettende ontgroening en vergrijzing van de beroepsbevolking en de verwachte groei van de werkgelegenheid zijn er, met name op VBO-niveau, een aantal opleidingstypen waarvoor er nauwelijks knelpunten in de personeelsvoorziening verwacht worden in 1998. In tabel 3.16 wordt een overzicht gegeven van de opleidingen waarvoor er (vrijwel) geen knelpunten in de personeelsvoorziening worden verwacht. Voor de opleiding VBO administratie, handel en textiel is de ITKP 1,22. Hieraan ligt met name de combinatie van het relatief grote aantal direct bemiddelbare werkzoekenden en het lage aantal baanopeningen ten grondslag. Bij de VBO-opleidingen administratie, handel en textiel en verzorging is er aan de aanbodzijde sprake van zowel een relatief hoge arbeidsmarktinstroom van schoolverlaters als een groot aantal direct bemiddelbare werkzoekenden. Bovendien is er aan de vraagzijde sprake van een relatief gering aantal baanopeningen. Voor de geringe knelpunten voor de opleiding VBO landbouw en natuurlijke omgeving is met name het geringe aantal baanopeningen verantwoordelijk. 
Tabel 3.16

Opleidingstypen met (vrijwel) geen knelpunten in de personeelsvoorziening in Limburg in 1998

\begin{tabular}{lcl} 
Opleidingstype & ITKP & typering \\
\hline & & \\
VBO administratie, handel en textiel & 1,22 & geen \\
VBO vervoer & 1,13 & vrijwel geen \\
VBO landbouw en natuurlijke omgeving & 1,12 & vrijwel geen \\
HAVO/NWO & 1,11 & vrijwel geen \\
VBO verzorging & 1,11 & vrijwel geen \\
Basisonderwijs & 1,11 & vrijwel geen \\
MAVO & 1,09 & vrijwel geen \\
MBO/LLW werktuigbouw en mechanische techniek & 1,08 & vrijwel geen \\
MBO sociaal-cultureel & 1,07 & vrijwel geen
\end{tabular}

Bron: ROA

Ook de knelpunten in de personeelsvoorziening voor de algemene opleidingen Basisonderwijs, MAVO, HAVO en VWO zijn gering. De oorzaken zijn met name bij het arbeidsaanbod te vinden. Er zijn relatief veel direct bemiddelbare werkzoekenden met een MAVO-, HAVO- of VWO-opleiding, zonder een afgeronde beroepsopleiding. Bij het Basisonderwijs, het HAVO en het VWO is bovendien de arbeidsmarktinstroom van schoolverlaters voldoende groot om de baanopeningen te vervullen. Voor de opleiding MBO/LLW werktuigbouw en mechanische techniek zijn de verwachte knelpunten met name gering, omdat er voldoende direct bemiddelbare werkzoekenden beschikbaar zijn.

Vier, gezien het aantal werkenden, kleine opleidingen waarvoor vrijwel geen knelpunten in de personeelsvoorziening worden verwacht, zijn niet in tabel 3.16 genoemd. Dit zijn de opleidingen VBO grafische techniek en de MBO/Leerlingwezen-opleidingen laboratorium, beweging en therapie en toerisme en recreatie.

Wanneer er voor een opleiding (vrijwel) geen knelpunten in de personeelsvoorzienig verwacht worden, dan is het voor werkgevers betrekkelijk gemakkelijk een geschikte kandidaat te vinden die een opleidingsachtergrond heeft die goed aansluit bij de functieeisen. Dit betekent echter dat de arbeidsmarktperspectieven voor schoolverlaters met deze opleiding matig tot slecht zijn. Weinig knelpunten impliceren immers een aanbodoverschot en daarmee een relatief kleine kans op het vinden van een baan op een niveau en in een richting waarop men toen men aan de opleiding begon zou mogen rekenen. 


\subsection{Inleiding}

Evenals in hoofdstuk 3 wordt in dit hoofdstuk ingegaan op de toekomstige ontwikkelingen op de Limburgse arbeidsmarkt. Stonden in hoofdstuk 3 de ontwikkelingen in 1998 centraal; in dit hoofdstuk worden de te verwachten middellange-termijnontwikkelingen, dat wil zeggen de arbeidsmarktontwikkelingen tot 2002, nader belicht. Middellange-termijnprognoses kunnen in de eerste plaats van belang zijn in het licht van de rol van het onderwijs in het verbeteren van de aansluiting tussen onderwijs en arbeidsmarkt. Degenen die nu voor hun studiekeuze staan kunnen met deze informatie inzicht verkrijgen in de verwachte arbeidsmarktsituatie op het moment dat zij na het afronden van hun opleiding instromen op de arbeidsmarkt. Naast deze voorlichtingsfunctie kunnen middellange-termijnprognoses een instrument zijn om richting te geven aan het onderwijs- en scholingsbeleid. Een derde doelgroep zijn de werkgevers voor wie de prognose-uitkomsten aanwijzingen geven waar zich in de toekomst problemen in de personeelsvoorziening zullen voordoen, zodat zij hierop kunnen anticiperen.

De opzet van dit hoofdstuk is als volgt. In paragraaf 2 wordt aandacht geschonken aan de te verwachten ontwikkelingen in de arbeidsvraag verbijzonderd naar beroepsgroep en opleidingstype, als gevolg van de verwachte ontwikkelingen in de werkgelegenheid in de verschillende bedrijfssectoren en de verschuivingen in de beroepen- en opleidingenstructuur binnen bedrijfssectoren: de zogenaamde uitbreidingsvraag. In paragraaf 3 staat de te verwachten vraag als gevolg van de mobiliteit en de uitstroom van werkenden centraal: de zogenaamde vervangingsvraag. Uitbreidings- en vervangingsvraag tezamen vormen de baanopeningen voor nieuwkomers die in paragraaf 4 zullen worden belicht. In paragraaf 5 wordt aandacht geschonken aan de te verwachten ontwikkelingen aan de aanbodzijde, in het bijzonder de verwachte instroom van schoolverlaters. In de paragrafen 6 en 7 leidt een confrontatie van vraag en aanbod tot een beeld van de verwachte aansluitingsproblemen op de Limburgse arbeidsmarkt op de middellange termijn. In het bijzonder zullen hier de arbeidsmarktperspectieven voor nieuwkomers centraal staan ${ }^{55}$. In paragraaf 6 wordt aandacht geschonken aan de opleidingen op VBO- en MBO/Leerlingwezen-niveau. In paragraaf 7 ten slotte wordt een indicatie gegeven van de verwachte arbeidsmarktsituatie voor hoger opgeleiden op de middellange termijn.

\subsection{Uitbreidingsvraag}

\section{Beroepen}

Door de uiteenlopende werkgelegenheidsontwikkelingen in de diverse bedrijfssectoren en de

55. In paragraaf 3.1 is reeds uitgebreid aandacht geschonken aan de opzet van het prognosemodel en aan de verschillende vraag- en aanbodprognoses. 
verschuivingen in de beroepenstructuur binnen de bedrijfssectoren, zijn er grote verschillen in de verwachte uitbreidingsvraag tot 2002 tussen de diverse beroepsgroepen.

Tabel 4.1 geeft een overzicht van de beroepsgroepen met de relatief hoogste uitbreidingsvraag, dat wil zeggen: de hoogste uitbreidingsvraag in verhouding tot de werkgelegenheid in de betreffende beroepsgroep ${ }^{56}$. De tabel laat een divers beeld zien. Evenals in 1998 wordt tot 2002 de hoogste uitbreidingvraag verwacht voor de beroepsgroep productieplanners. Tot 2002 zal de uitbreidingsvraag naar verwachting $49 \%$ bedragen. Dit betekent een gemiddelde jaarlijkse groei van ruim $8 \%{ }^{57}$. Deze erg hoge uitbreidingsvraag is met name toe te schrijven aan de naar verwachting hoge werkgelegenheidsgroei in de metaalsector. Een vergelijking met de te verwachten ontwikkelingen in 1998 laat trouwens weinig verschillen zien. Bij de meeste beroepsgroepen zal de relatief hoge uitbreidingsvraag zich in 1998 naar verwachting doorzetten tot 2002. Zo blijft bijvoorbeeld de groei in de werkgelegenheid in de automatiseringsberoepen - systeemanalisten en programmeurs onverminderd hoog. Een uitzondering vormt de beroepsgroep agrarische arbeiders. In 1998 wordt voor deze beroepsgroep nog een relatief hoge uitbreidingsvraag van $3,8 \%$ verwacht, waarmee deze beroepsgroep tot de sterke groeiers mag worden gerekend. Tot 2002 zal de uitbreidingsvraag voor deze beroepsgroep naar verwachting jaarlijks ruim $1 \%$ bedragen, hetgeen als gemiddeld getypeerd kan worden. De achterblijvende groei in de landbouwsector ligt hieraan ten grondslag. Een vergelijking met het landelijke beeld laat ten slotte voor de hier genoemde beroepsgroepen een vergelijkbaar beeld zien.

56. Opgemerkt dient te worden dat in de in dit hoofdstuk gepresenteerde tabellen alleen beroepsgroepen en opleidingstypen zijn opgenomen waarin meer dan 2.000 mensen werkzaam zijn. Voor de kleinere beroepsgroepen en opleidingstypen worden, in het licht van de betrouwbaarheid, alleen kwalitatieve typeringen van de prognoses gepresenteerd. Zie voor een volledig overzicht hoofdstuk 6 van de Statistische Bijlage.

57. Het gemiddeld jaarlijks groeipercentage kan berekend worden door de vijfdemachtswortel van het totale groeipercentage te nemen. 
Tabel 4.1

Beroepsgroepen met relatief de hoogste uitbreidingsvraag in Limburg tot 2002 (percentage van de werkgelegenheid)

\begin{tabular}{lll}
\hline Beroepsgroep & $\%$ & typering \\
\hline & & \\
Productieplanners & 49 & erg hoog \\
Ziekenverzorgenden & 30 & erg hoog \\
Boekhouders en secretaresses & 24 & erg hoog \\
Systeemanalisten & 21 & hoog \\
Activiteitenbegeleiders en medew. arbeidsbemiddeling & 17 & hoog \\
Programmeurs & 17 & hoog \\
Commercieel medewerkers & 14 & hoog \\
Kantoorhulpen, inpakkers en colporteurs & 14 & hoog \\
\hline
\end{tabular}

Bron: ROA

Tabel 4.2

Beroepsgroepen met relatief de laagste uitbreidingsvraag in Limburg tot 2002 (percentage van de werkgelegenheid)

Beroepsgroep $\quad \% \quad$ typering

Docenten exacte, medische en verz. vakken (2e gr.)

Politie-agenten, onderofficieren en beveiligingsemp.

Receptionisten en administratieve employés

Docenten economisch-adm. vakken (1e graads)

Therapeuten en verpleegkundigen

Mechanisch operators

Hulpkrachten horeca en verzorging

Docenten landbouw en techniek (2e graads)

$\begin{aligned}-7 & \text { erg laag } \\ -6 & \text { erg laag } \\ -4 & \text { erg laag } \\ -4 & \text { erg laag } \\ -1 & \text { laag } \\ -1 & \text { laag } \\ -1 & \text { laag } \\ 2 & \text { laag }\end{aligned}$

\section{Bron: ROA}

In tabel 4.2 wordt een overzicht gegeven van de beroepsgroepen met de laagste uitbreidingsvraag. In zeven van de acht gevallen is zelfs sprake van krimp. De tabel laat zien dat de krimppercentages klein zijn vergeleken met de groeipercentages zoals die gepresenteerd zijn in tabel 4.1. Dit valt toe te schrijven aan de werkgelegenheidsgroei die in de meeste bedrijfssectoren wordt verwacht. Uit de tabel blijkt tevens dat, evenals in 1998, de verschillende docentenberoepen een belangrijke plaats innemen binnen de krimpende beroepsgroepen. De ontgroening van de bevolking en de ombuigingen in het onderwijs spelen hierbij een belangrijke rol. Veranderende opleidings- en vakkenpakketkeuzes van leerlingen zouden daarnaast ten grondslag kunnen liggen aan de krimp in de vraag naar docenten in specifieke richtingen. Ook landelijk is dit beeld zichtbaar. In het algemeen levert de middellange-termijnprognose een soortgelijk beeld op als de korte-termijnprognose voor 1998. Opvallend is dat de krimp in de vraag naar de mechanisch operators versterkt doorzet, terwijl uit tabel 4.1 bleek dat de groei in de automatiseringsberoepen onverminderd hoog is. Dit illustreert het toenemend belang van de automatisering in de industrie. Hierbij 
kan tevens gewezen worden op de steeds verdere indaling van de automatisering ${ }^{58}$. Enerzijds is er behoefte aan hoger opgeleiden die de apparatuur en programmatuur kunnen ontwikkelen en onderhouden; anderzijds zijn er voor het bedienen van de apparatuur in toenemende mate lager opgeleiden nodig ${ }^{59}$.

\section{Opleidingen}

Tabel 4.3 laat zien voor welke opleidingstypen tot 2002 relatief de hoogste uitbreidingsvraag verwacht wordt. Evenals bij de prognose voor 1998 bevat de tabel uitsluitend opleidingen op MBO/Leerlingwezen-niveau of hoger. Dit geeft aan dat er in de komende vijf jaar sprake zal zijn van een aanzienlijke upgrading van de opleidingseisen. De grootste groei wordt evenals in 1998 verwacht voor de opleidingstypen WO econom(etr)ie en MBO/LLW milieu en groene ruimte. De uitbreidingsvraag in de periode 1997-2002 voor deze opleidingstypen is naar verwachting respectievelijk 37 en 31 procent. Dit betekent voor WO econom(etr)ie een gemiddeld jaarlijkse groei van bijna $7 \%$; voor MBO/LLW milieu en groene ruimte $5,5 \%$. Ook de groei voor de MBO/Leerlingwezen-opleidingen procestechniek, sociaal-cultureel, vervoer en horeca zet naar verwachting door. Opvallend is de hoge uitbreidingsvraag voor HBO informatica. Voor 1998 wordt voor dit opleidingstype slechts een gemiddelde groei verwacht. Dit illustreert het toenemend belang van de automatisering. Vergeleken met het landelijke beeld is de hoge uitbreidingsvraag voor MBO/LLW vervoer opvallend. Liggen over het algemeen de landelijke groeipercentages iets hoger dan de Limburgse; voor MBO/LLW vervoer wordt in Limburg een groei van $24 \%$ verwacht, terwijl dit percentage landelijk 21 bedraagt.

Tabel 4.3

Opleidingstypen met relatief de hoogste uitbreidingsvraag in Limburg tot 2002 (percentage van de werkgelegenheid)

Opleidingstype $\quad \% \quad$ typering

$\begin{array}{lll}\text { WO econom(etr)ie } & 37 & \text { erg hoog } \\ \text { MBO/LLW milieu en groene ruimte } & 31 & \text { hoog } \\ \text { HBO informatica } & 25 & \text { hoog } \\ \text { MBO/LLW procestechniek } & 25 & \text { hoog } \\ \text { MBO sociaal-cultureel } & 24 & \text { hoog } \\ \text { MBO/LLW vervoer } & 24 & \text { hoog } \\ \text { MBO/LLW horeca } & 24 & \text { hoog } \\ \text { HBO bedrijfskunde } & 23 & \text { hoog }\end{array}$

Bron: ROA

Tabel 4.4 brengt de opleidingstypen in beeld waarvoor de grootste krimp wordt verwacht.

58. Zie Van Camp, H., 1997d, op. cit.

59. Zie Van Camp, H., 1997d, op. cit. 
Het opleidingsniveau van de in deze tabel genoemde opleidingen is over het algemeen laag. Dit illustreert het al eerder genoemde upgradingsproces van de opleidingseisen, dat overigens ook landelijk zichtbaar is. Opmerkelijk is dat de percentages in deze tabel veel hoger zijn dan de percentages die de prognoses per beroepsgroep lieten zien in tabel 4.2. Dit betekent dat het upgradingsproces met name binnen de beroepsgroepen plaatsvindt. Een uitzondering op het lage niveau van de in de tabel genoemde opleidingstypen vormt HBO lerarenopleiding talen. De krimp voor dit opleidingstype valt toe te schrijven aan de al eerder gememoreerde krimp in de lerarenberoepen. Evenals bij de prognose voor 1998 wordt de grootste krimp verwacht voor de 'ongeschoolde' arbeidskrachten met slechts Basisonderwijs. De gemiddelde jaarlijkse krimp neemt echter iets af. Wordt in 1998 nog een daling van de vraag van $5,2 \%$ verwacht; tot 2002 zal het gemiddeld jaarlijks percentage naar verwachting 3,5 bedragen. Ook de krimp in de vraag naar de VBO-opleidingen administratie, handel en textiel, landbouw en natuurlijke omgeving en motorvoertuigentechniek zal zich naar verwachting na 1998 voortzetten.

Tabel 4.4

Opleidingstypen met relatief de laagste uitbreidingsvraag in Limburg tot 2002 (percentage van de werkgelegenheid)

Opleidingstype $\quad \% \quad$ typering

$\begin{array}{lcc}\text { Basisonderwijs } & -17 & \text { erg laag } \\ \text { VBO administratie, handel en textiel } & -13 & \text { erg laag } \\ \text { VBO landbouw en natuurlijke omgeving } & -11 & \text { erg laag } \\ \text { VBO fijnmechanische techniek } & -10 & \text { erg laag } \\ \text { VBO motorvoertuigentechniek } & -9 & \text { laag } \\ \text { HBO lerarenopleiding talen } & -8 & \text { laag } \\ \text { MBO/LLW geld, bank en belastingen } & -7 & \text { laag } \\ \text { VBO horeca en levensmiddelentechniek } & -6 & \text { laag }\end{array}$

Bron: ROA

\subsection{Vervangingsvraag}

\section{Beroepen}

Vervangingsvraag is de vraag naar nieuwe arbeidskrachten die ontstaat doordat arbeidsplaatsen van werkenden vrijkomen, die met pensioen gaan, die arbeidsongeschikt worden of die zich terugtrekken van de arbeidsmarkt. Bij de verbijzondering van de vervangingsbehoefte naar beroepsgroep moet bovendien rekening worden gehouden met de vervangingsvraag vanwege de beroepsmobiliteit van werkenden.

In tabel 4.5 wordt een overzicht gegeven van de beroepsgroepen waarvoor tot 2002 relatief de hoogste vervangingsvraag wordt verwacht. In vergelijking met de prognose voor 1998 nemen de docentenberoepen een nog prominentere plaats in. Dit komt tot uiting in het feit 
dat nu ook, in tegenstelling tot de prognose voor 1998, de docenten exacte, medische en verzorgende vakken (2e graads) tot de beroepsgroepen met relatief de hoogste vervangingsvraag behoren. Het in deze tabel geschetste beeld komt overigens voor een groot deel overeen met de prognose voor 1998. Vergeleken met het landelijke beeld valt op dat de vervangingsvraagpercentages in Limburg over het algemeen aanmerkelijk hoger zijn. De vervangingsvraag voor docenten landbouw en techniek bijvoorbeeld bedraagt landelijk naar verwachting $35 \%$, terwijl er in Limburg een vervangingsbehoefte van $39 \%$ verwacht wordt. Het meest opmerkelijke verschil treedt op bij de managers. Terwijl landelijk een vervangingsvraag van $26 \%$ wordt verwacht; zal de vervangingsbehoefte in Limburg $10 \%$ hoger zijn. De relatief hoge verwachte vervangingsvraag in Limburg is een uitvloeisel van de snelle vergrijzing van de Limburgse beroepsbevolking.

Tabel 4.5

Beroepsgroepen met relatief de hoogste vervangingsvraag in Limburg tot 2002 (percentage van de werkgelegenheid)

\begin{tabular}{lll} 
Beroepsgroep & $\%$ & typering \\
\hline & & erg hoog \\
Docenten landbouw en techniek (2e graads) & 39 & erg hoog \\
Managers & 36 & erg goog \\
Café- en snackbarhouders & 35 & erg hoog \\
Conciërges & 33 & erg hoog \\
Docenten talen en expressie & 30 & erg hoog \\
Receptionisten en administratieve employés & 27 & hoog \\
Docenten exacte, medische en verz. vakken (2e graads) & 26 & hoog \\
Hulpkrachten horeca en verzorging & 24 &
\end{tabular}

Bron: ROA

Tabel 4.6 geeft een overzicht van de beroepsgroepen waarvoor naar verwachting de vervangingsvraag tot 2002 relatief het laagst zal zijn. Enerzijds zijn dit sterk groeiende beroepsgroepen zoals programmeurs en kantoorhulpen, inpakkers en colporteurs. De hoge uitbreidingsvraag leidt ertoe dat de werkenden in deze beroepsgroepen relatief jong zijn en bovendien een lage beroepsmobiliteit zullen vertonen. Anderzijds bevat deze tabel beroepsgroepen die van oudsher gekenmerkt worden door een lage gemiddelde leeftijd van de werkenden zoals verzorgend personeel en boekhouders en secretaresses. Ook landelijk worden deze beroepsgroepen overigens gekenmerkt door een lage vervangingsvraag. 
Tabel 4.6

Beroepsgroepen met relatief de laagste vervangingsvraag in Limburg tot 2002 (percentage van de werkgelegenheid)

\begin{tabular}{lcc} 
Beroepsgroep & $\%$ & typering \\
\hline & & erg laag \\
Programmeurs & 4 & erg laag \\
Activiteitenbegeleiders en medew. arbeidsbem. & 9 & erg laag \\
Laders en lossers & 10 & erg laag \\
Verzorgend personeel & 10 & erg laag \\
Kantoorhulpen, inpakkers en colporteurs & 11 & laag \\
Boekhouders en secretaresses & 12 & laag \\
Assistent accountants & 12 & laag \\
Juristen & 13 & \\
& &
\end{tabular}

Bron: ROA

\section{Opleidingen}

In tabel 4.7 worden de opleidingstypen met relatief de hoogste verwachte vervangingsvraag tot 2002 weergegeven. Uit het ook in hoofdstuk 3 geschetste beeld blijkt dat in het bijzonder bij degenen die een lerarenopleiding hebben gevolgd, sprake is van een hoge vervangingsvraag. Zoals al eerder werd aangegeven speelt de vergrijzing bij de leraren hierbij een belangrijke rol. Ook de relatief hoge vervangingsvraag voor WO wiskunde en natuurwetenschappen - een gemiddeld jaarlijkse vervangingsbehoefte van ruim $5 \%$ - wordt veroorzaakt door het feit dat veel (oudere) werkenden met deze opleidingsachtergrond in het onderwijs werkzaam zijn. MBO/LLW bedrijfskunde en WO (dier)geneeskunde zijn opleidingstypen waarin het aandeel van jongeren laag is. Aangezien jongeren verhoudingsgewijs een lage uitstroom kennen, worden deze opleidingstypen gekenmerkt door een hoge vervangingsvraag.

Tabel 4.7

Opleidingstypen met relatief de hoogste vervangingsvraag in Limburg tot 2002 (percentage van de werkgelegenheid)

Opleidingstype $\quad \% \quad$ typering

WO wiskunde en natuurwetenschappen

HBO lerarenopleiding expressie

HBO lerarenopleiding talen

MBO/LLW bedrijfskunde

HBO lerarenopleiding natuur en techniek

WO sociale wetenschappen

WO (dier)geneeskunde

erg hoog

erg hoog

hoog

hoog

gemiddeld

gemiddeld

gemiddeld

gemiddeld

Bron: ROA 
De leeftijdsopbouw speelt een belangrijke rol bij de vervangingsvraag. De toenemende vergrijzing leidt tot een hogere vervangingsbehoefte. De vergrijzing manifesteert zich overigens in Limburg sterker dan landelijk. De vervangingsbehoefte is in Limburg over het algemeen weer wat hoger dan landelijk.

Tabel 4.8 geeft een overzicht van de opleidingstypen die naar verwachting relatief de laagste vervangingsvraag zullen kennen tot 2002. Net als bij de beroepsgroepen speelt een snelle groei van de werkgelegenheid hierbij een belangrijke rol, zoals bij de MBO/Leerlingwezenopleidingen milieu en groene ruimte en horeca. Een snelle groei van de werkgelegenheid leidt tot een lage gemiddelde leeftijd van de werkenden en daarmee tot een lage uitstroom. Ook bij de andere in deze tabel genoemde opleidingstypen wordt de lage vervangingsvraag met name veroorzaakt door een lage uitstroom als gevolg van een lage gemiddelde leeftijd van de werkenden. Een uitzondering vormt HBO verpleegkunde. Ook gezien het hoge percentage vrouwen is de lage verwachte vervangingsvraag voor dit opleidingstype verassend.

Tabel 4.8

Opleidingstypen met relatief de laagste vervangingsvraag in Limburg tot 2002 (percentage van de werkgelegenheid)

\begin{tabular}{lcl}
\hline Opleidingstype & $\%$ & typering \\
\hline & 5 & erg laag \\
VBO administratie, handel en textiel & 8 & erg laag \\
MBO/LLW horeca & 9 & erg laag \\
MBO/LLW milieu en groene ruimte & 10 & erg laag \\
HAVO/NWO & 10 & erg laag \\
VBO landbouw en natuurlijke omgeving & 10 & erg laag \\
MBO/LLW secretariaat & 11 & erg laag \\
VBO horeca en levensmiddelentechniek & 11 & erg laag \\
HBO verpleegkunde & & \\
\hline
\end{tabular}

Bron: ROA

\subsection{Baanopeningen}

\section{Beroepen}

De (positieve) uitbreidingsvraag en de vervangingsvraag vormen tezamen het aantal baanopeningen voor nieuwkomers op de arbeidsmarkt. In tabel 4.9 wordt een overzicht gegeven van de beroepsgroepen waarvoor het aantal baanopeningen verhoudingsgewijs het grootst is. Evenals in 1998 wordt tot 2002 het relatief grootste aantal baanopeningen verwacht voor de productieplanners. Hieraan ligt met name de hoge uitbreidingsvraag ten grondslag. Voor 1998 wordt het percentage baanopeningen op 10,7\% geschat; tot 2002 zal dit percentage jaarlijks gemiddeld ruim 10 bedragen. Deze lichte afname van het percentage baanopeningen na 1998 wordt overigens voor een groot aantal beroepsgroepen verwacht. 
Deze afname valt met name toe te schrijven aan een afname van de werkgelegenheidsgroei binnen de verschillende bedrijfssectoren. De tabel bevat enerzijds beroepsgroepen waarbij het grote aantal baanopeningen toe te schrijven is aan de hoge uitbreidingsvraag. Naast de productieplanners zijn dit de kantoorhulpen, inpakkers en colporteurs, de ziekenverzorgenden en de boekhouders en secretaresses (zie tabel 4.1). De baanopeningen voor de café- en snackbarhouders, de conciërges, de managers en de docenten landbouw en techniek komen daarentegen met name voort uit een relatief hoge vervangingsvraag (zie tabel 4.5).

Tabel 4.9

Beroepsgroepen met relatief het hoogste aantal baanopeningen in Limburg tot 2002 (percentage van de werkgelegenheid)

\begin{tabular}{lll} 
Beroepsgroep & $\%$ & typering \\
\hline & & \\
Productieplanners & 63 & erg hoog \\
Managers & 47 & hoog \\
Ziekenverzorgenden & 46 & hoog \\
Café- en snackbarhouders & 42 & hoog \\
Docenten landbouw en techniek (2e graads) & 40 & hoog \\
Conciërges & 39 & hoog \\
Boekhouders en secretaresses & 36 & hoog \\
Leidinggevenden & 35 & hoog
\end{tabular}

Bron: ROA

Uit tabel 4.10, waarin een overzicht wordt gegeven van de beroepsgroepen met verhoudingsgewijs het laagste aantal verwachte baanopeningen tot 2002, blijkt dat voor de mechanisch operators relatief het laagste aantal baanopeningen wordt verwacht. In deze beroepsgroep is sprake van een krimpende werkgelegenheid; baanopeningen ontstaan alleen als gevolg van de uitstroom van werkenden. Tot 2002 zal naar verwachting $16 \%$ van de werkenden vervangen worden. Dit is gemiddeld ruim $3 \%$ per jaar. Ook de beroepsgroep politie-agenten, onderofficieren en beveiligingsemployés wordt gekenmerkt door een krimpende werkgelegenheid waardoor nieuwkomers op de arbeidsmarkt alleen werk kunnen vinden wanneer werkenden de arbeidsmarkt verlaten of een ander beroep kiezen. De laders en lossers en de juristen zijn voorbeelden van beroepsgroepen die gekenmerkt worden door een relatief lage vervangingsvraag. Bij deze beroepsgroepen is de geringe uitstroom of beroepsmobiliteit van de werkenden verantwoordelijk voor het relatief lage aantal baanopeningen. Beroepsgroepen waarvoor een lage vervangingsvraag met name samenhangt met een snelle groei van de werkgelegenheid, waardoor er relatief veel jongeren in deze beroepsgroepen werkzaam zijn, zijn uiteraard niet in deze tabel terug te vinden, vanwege de hoge uitbreidingsvraag. Ook de docentenberoepen die, zoals eerder werd opgemerkt, gekenmerkt worden door een lage uitbreidingsvraag, zijn niet in tabel 4.10 terug te vinden, omdat in er het onderwijs sprake is van een relatief hoge vervangingsvraag. 
Tabel 4.10

Beroepsgroepen met relatief het laagste aantal baanopeningen in Limburg tot 2002 (percentage van de werkgelegenheid)

$\begin{array}{lll}\text { Beroepsgroep } & \% & \text { typering }\end{array}$

Mechanisch operators

Politie-agenten, onderofficieren en beveiligingsemp.

Procesoperators

Laders en lossers

Aannemers en installateurs

Monteurs

Sociaal-cultureel werkers

Juristen
16

17

19

19

19

20

20

20
laag
laag
gemiddeld
gemiddeld
gemiddeld
gemiddeld
gemiddeld
gemiddeld

Bron: ROA

Een vergelijking met de prognose voor 1998 laat zien dat de mechanisch operators naar verwachting snel terrein zullen verliezen op de Limburgse arbeidsmarkt. Is het aantal baanopeningen in 1998 naar verwachting nog 3,7\%, tot 2002 zal dit jaarlijks gemiddeld slechts ongeveer $3 \%$ bedragen. Ook het aantal baanopeningen voor de procesoperators neemt verder af: 3,7\% in 1998 tegenover jaarlijks gemiddeld bijna 3,5\% tot 2002. Opvallend is dat de productiemedewerkers niet in tabel 4.10 voorkomen. Voor 1998 wordt verwacht dat het aantal baanopeningen voor deze beroepsgroep slechts 2,9\% van het aantal werkenden zal bedragen. Tot 2002 zal het aantal baanopeningen naar verwachting toenemen tot gemiddeld bijna $4 \%$ per jaar.

\section{Opleidingen}

Tabel 4.11 laat zien voor welke opleidingstypen het aantal baanopeningen tot 2002 verhoudingsgewijs het hoogst zal zijn. De tabel bevat uitsluitend opleidingstypen op MBO/Leerlingwezen-niveau of hoger. Net als in 1998 wordt het hoogste aantal baanopeningen verwacht voor WO econom(etr)ie. Het aantal baanopeningen zal echter licht afnemen. Voor 1998 wordt nog verwacht dat de baanopeningen 9,8\% van de huidige werkgelegenheid bedragen; tot 2002 zal dit gemiddeld bijna 9 procent per jaar zijn. Met name de hoge uitbreidingsvraag is verantwoordelijk voor het hoge aantal baanopeningen. De tabel wordt overigens gedomineerd door opleidingstypen die gekenmerkt worden door een hoge uitbreidingsvraag. Naast WO econom(etr)ie, kennen de opleidingstypen HBO bedrijfskunde en informatica en de MBO/Leerlingwezen-opleidingen vervoer, milieu en groene ruimte, procestechniek en sociaal-cultureel een relatief hoge uitbreidingsvraag (zie tabel 4.3). Het is dus vooral de groei in de werkgelegenheid voor deze opleidingstypen die zorgt voor het hoge aantal baanopeningen. De upgrading van de opleidingseisen op de Limburgse arbeidsmarkt speelt hierbij een belangrijke rol. Het relatief hoge aantal baanopeningen voor nieuwkomers met een opleiding WO sociale wetenschappen kan daarentegen met name toegeschreven worden aan de hoge vervangingsvraag (zie tabel 
4.7). De verwachting dat veel werkenden met deze opleidingsachtergrond de arbeidsmarkt zullen verlaten, leidt voor dit opleidingstype tot een relatief hoog aantal baanopeningen voor nieuwkomers.

Tabel 4.11

Opleidingstypen met relatief het hoogste aantal baanopeningen in Limburg tot 2002 (percentage van de werkgelegenheid)

\begin{tabular}{lll} 
Opleidingstype & $\%$ & typering \\
\hline WO econom(etr)ie & 52 & hoog \\
MBO/LLW vervoer & 42 & gemiddeld \\
WO sociale wetenschappen & 42 & gemiddeld \\
MBO/LLW milieu en groene ruimte & 39 & gemiddeld \\
MBO/LLW procestechniek & 39 & gemiddeld \\
MBO sociaal-cultureel & 38 & gemiddeld \\
HBO bedrijfskunde & 38 & gemiddeld \\
HBO informatica & 37 & gemiddeld
\end{tabular}

Bron: ROA

Tabel 4.12 brengt de opleidingstypen met het laagste aantal baanopeningen tot 2002 in beeld. Het niveau van de opleidingen in de tabel is laag. Met uitzondering van MBO/LLW verzorging komen er in de tabel uitsluitend VBO-opleidingen voor. Behalve de opleidingsrichting bouwtechniek zijn dit allemaal VBO-opleidingen die te kampen hebben met een krimpende werkgelegenheid. De baanopeningen voor deze opleidingen vinden dus uitsluitend hun oorsprong in de vervangingsbehoefte vanwege het vertrek van werkenden die de arbeidsmarkt verlaten. Ook deze tabel illustreert derhalve de upgrading van de opleidingseisen op de Limburgse arbeidsmarkt. Een goed voorbeeld vormt de richting vervoer. Op MBO/Leerlingwezen-niveau is er sprake van een relatief hoog aantal baanopeningen, vanwege een hoge uitbreidingsvraag (zie tabel 4.11). Op VBO-niveau zal de werkgelegenheid voor de richting vervoer daarentegen naar verwachting krimpen en is het aantal baanopeningen als gevolg daarvan relatief laag. 
Tabel 4.12

Opleidingstypen met relatief het laagste aantal baanopeningen in Limburg tot 2002 (percentage van de werkgelegenheid)

Opleidingstype $\quad \% \quad$ typering

VBO administratie, handel en textiel

VBO landbouw en natuurlijke omgeving

VBO horeca en levensmiddelentechniek

$\mathrm{MBO} / \mathrm{LLW}$ verzorging

VBO bouwtechniek

VBO motorvoertuigentechniek

VBO vervoer

VBO mechanische techniek

$\begin{aligned} 5 & \text { erg laag } \\ 10 & \text { erg laag } \\ 11 & \text { erg laag } \\ 14 & \text { laag } \\ 14 & \text { laag } \\ 15 & \text { laag } \\ 15 & \text { laag } \\ 15 & \text { laag }\end{aligned}$

Bron: ROA

De prognose voor 1998 laat een vergelijkbaar beeld zien. Voor de vier opleidingen met naar verwachting relatief het laagste aantal baanopeningen in 1998 is ook tot 2002 het aantal baanopeningen gering. Een uitzondering vormt $\mathrm{HBO}$ elektrotechniek. Uit tabel 3.13 bleek dat het aantal baanopeningen in 1998 nog relatief laag zal zijn (2,9\%). Tot 2002 zal het gemiddeld jaarlijks percentage naar verwachting echter op een duidelijk hoger niveau (bijna $5 \%$ ) liggen. Deze toename wordt vooral veroorzaakt door een stijgende uitbreidingsvraag.

\subsection{Instroom van schoolverlaters op de arbeidsmarkt}

De baanopeningen geven een indicatie van de ontwikkelingen aan de vraagzijde van de arbeidsmarkt. Om een beeld te kunnen vormen van de toekomstige arbeidsmarktsituatie moeten ook de aanbodontwikkelingen in beeld worden gebracht. Naast het aan het begin van de prognoseperiode boven de markt zwevende aanbod van direct bemiddelbare nietwerkende werkzoekenden gaat het hierbij vooral om de verwachte arbeidsmarktinstroom van schoolverlaters gedurende de periode 1997-2002.

Tussen de verschillende opleidingstypen zijn er aanzienlijke verschillen in de verwachte arbeidsmarktinstroom van schoolverlaters. Tabel 4.13 geeft een overzicht van de opleidingstypen waarvoor de verwachte arbeidsmarktinstroom in de periode tot 2002 verhoudingsgewijs het grootst is ${ }^{60}$. Drie factoren spelen hierbij een rol: het aantal leerlingen/studenten dat de opleiding heeft gekozen, het aantal werkenden met de betreffende opleidingsachtergrond en de mate waarin de opleiding het eindpunt vormt van de (initiële) opleiding. De relatief grootste arbeidsmarktinstroom wordt verwacht vanuit het $\mathrm{H}$ HAVO en het VWO. Hieraan ligt met name het relatief lage aantal werkenden met deze

60. Zoals reeds eerder werd opgemerkt worden alleen voor het Basisonderwijs, het AVO en de opleidingen op VBO- en MBO/Leerlingwezen-niveau regionale prognoses gepresenteerd. 
opleidingsachtergrond ten grondslag. Dit is vooral het gevolg van het feit dat veel werkenden met deze opleidingsachtergrond door het volgen van niet-initiële opleidingen een andere opleidingsachtergrond krijgen. Opvallend is het grote aantal VBO-opleidingen in de tabel. Deze opleidingen worden blijkbaar niet alleen vaak gekozen, afgestudeerden van deze opleidingen stromen blijkbaar niet door naar een MBO-opleiding of het Leerlingwezen, maar zijn direct beschikbaar voor de arbeidsmarkt. Een vergelijking met de prognose voor 1998 laat duidelijk het effect van de ontgroening zien. Over de gehele linie is er sprake van een afnemende instroom op de arbeidsmarkt. Zo daalt de arbeidsmarktinstroom vanuit HAVO/VWO van $7,8 \%$ in 1998 tot jaarlijks gemiddeld bijna $6 \%$ gedurende de periode 1997 2002.

Tabel 4.13

Opleidingstypen met relatief de grootste instroom in Limburg tot 2002 (percentage van de werkgelegenheid)

\begin{tabular}{lll} 
Opleidingstype & $\%$ & typering \\
\hline HAVO/VWO & 32 & hoog \\
MBO sociaal-cultureel & 32 & hoog \\
Basisonderwijs & 26 & laag \\
VBO administratie, handel en textiel & 22 & gemiddeld \\
MBO/LLW uiterlijke verzorging & 19 & gemiddeld \\
VBO motorvoertuigentechniek & 17 & gemiddeld \\
VBO horeca en levensmiddelentechniek & 16 & gemiddeld \\
MBO/LLW secretariaat & 15 & gemiddeld
\end{tabular}

Bron: ROA

\subsection{Arbeidsmarktperspectieven voor nieuwkomers en knelpunten in de personeelsvoorziening in 2002}

Op basis van de in dit hoofdstuk geschetste verwachte ontwikkelingen aan de vraag- en de aanbodzijde van de arbeidsmarkt, kan een indicatie worden gegeven van de te verwachten arbeidsmarktperspectieven voor nieuwkomers op de arbeidsmarkt, verbijzonderd naar opleidingstype. De uitspraken op dit punt zijn gebaseerd op de Indicator Toekomstige Arbeidsmarktperspectieven (ITA) die voor elk opleidingstype de verhouding weergeeft tussen het arbeidsaanbod met de betreffende opleidingsachtergrond en de daar tegenover staande vraag. Wanneer het aanbod kleiner is dan de vraag, en de ITA dus kleiner is dan 1,00 worden de perspectieven als goed getypeerd. Als de waarde van de ITA kleiner is dan 0,85 wordt gesproken van een zeer goed arbeidsmarktperspectief. Wanneer de ITA daarentegen een waarde heeft tussen 1,00 en 1,05 en het aanbodoverschot niet veel groter is dan wat als frictie kan worden beschouwd, wordt gesproken van een redelijk arbeidsmarktperspectief. $\mathrm{Bij}$ een hogere waarde van de ITA wordt het arbeidsmarktperspectief voor het betreffende opleidingstype als matig aangeduid, of als de ITA zelfs groter is dan 1,15 , als slecht aangeduid. 


\section{Opleidingen met zeer goede perspectieven}

De voor de periode 1997-2002 verwachte relatief gunstige arbeidsmarktontwikkelingen in Limburg zullen ertoe leiden dat voor een groot aantal opleidingstypen goede tot zeer goede arbeidsmarktperspectieven worden verwacht. Voor maar liefst 40 van de 52 onderscheiden opleidingen op $\mathrm{MBO} /$ Leerlingwezen-niveau of lager $(77 \%)$ wordt een goed tot zeer goed perspectief verwacht. Met name op MBO/Leerlingwezen-niveau, waar voor 31 van de 35 opleidingen (90\%) het perspectief goed tot zeer goed is, is er sprake van een aanbodtekort. Voor 1998 zijn deze percentages respectievelijk 60 en 74. Na 1998 zal de Limburgse arbeidsmarkt naar verwachting dus verder verkrappen. Naast de gunstige werkgelegenheidsontwikkeling in de verschillende bedrijfssectoren, zijn de dalende arbeidsmarktinstroom en de toenemende vervangingsbehoefte als gevolg van de vergrijzing de belangrijkste oorzaken van de toenemende krapte op de Limburgse arbeidsmarkt. Landelijk wordt voor $64 \%$ van de opleidingen op MBO/Leerlingwezen-niveau of lager een goed tot zeer goed perspectief voorspeld. Voor de opleidingen op MBO/Leerlingwezenniveau is dit landelijk percentage 74 . Op de Limburgse arbeidsmarkt zullen de aanbodtekorten derhalve naar verwachting sterker merkbaar zijn dan landelijk, waardoor de perspectieven voor de Limburgse nieuwkomers gemiddeld genomen beter zijn dan voor de nieuwkomers in de rest van het land. Dit verschil met het landelijke beeld valt met name toe te schrijven aan demografische factoren; met name de vervangingsvraag zal naar verwachting in Limburg aanzienlijk hoger zijn dan landelijk, als gevolg van de snelle vergrijzing van de Limburgse beroepsbevolking ${ }^{61}$.

Tabel 4.14

Opleidingstypen met zeer goede arbeidsmarktperspectieven in Limburg in 2002

$\begin{array}{lll}\text { Opleidingstype } & \text { ITA typering }\end{array}$

$\begin{array}{lll}\text { MBO/LLW vervoer } & 0,73 & \text { zeer goed } \\ \text { MBO/LLW procestechniek } & 0,74 & \text { zeer goed } \\ \text { MBO/LLW bedrijfskunde } & 0,76 & \text { zeer goed } \\ \text { MBO/LLW verpleging } & 0,79 & \text { zeer goed } \\ \text { MBO/LLW bouw } & 0,80 & \text { zeer goed } \\ \text { MBO/LLW motorvoertuigentechniek } & 0,81 & \text { zeer goed } \\ \text { MBO/LLW automatisering } & 0,82 & \text { zeer goed } \\ \text { MBO/LLW horeca } & 0,85 & \text { zeer goed } \\ \text { MBO/LLW geld, bank en belastingen } & 0,85 & \text { zeer goed }\end{array}$

Bron: ROA

In tabel 4.14 wordt een overzicht gegeven van de opleidingstypen waarvoor een zeer goed arbeidsmarktperspectief in 2002 wordt voorspeld. Dit blijken uitsluitend opleidingen op

61. Zie ook Van Camp, H., 1997d, op. cit. 
MBO/Leerlingwezen-niveau te zijn. De technische richtingen - vervoer, procestechniek, bouwtechniek, motorvoertuigentechniek en automatisering - domineren de tabel. Deze richtingen kennen een gemiddelde tot hoge uitbreidingsvraag, mede als gevolg van de upgrading van de opleidingseisen. De vervangingsvraag bij deze opleidingen is daarentegen laag. Naast de werkgelegenheidsgroei speelt de lage arbeidsmarktinstroom een belangrijke rol bij het goede perspectief van deze technische opleidingen op MBO/Leerlingwezenniveau. De opleiding MBO/LLW horeca wordt met name gekenmerkt door een hoge uitbreidingsvraag, terwijl bij de opleiding MBO/LLW bedrijfskunde met name de hoge vervangingsvraag verantwoordelijk is voor het zeer goede perspectief.

\section{Opleidingen met een redelijk tot slecht perspectief}

Ondanks de toenemende krapte op de Limburgse arbeidsmarkt zijn er, met name op VBOniveau, een aantal opleidingen waarvoor de arbeidsmarktperspectieven in 2002 redelijk tot slecht zijn. In tabel 4.15 wordt een overzicht gegeven van deze opleidingen. Aan het slechte arbeidsmarktperspectief voor degenen met de opleidingsachtergrond VBO administratie, handel en textiel ligt met name het lage aantal baanopeningen ten grondslag. Er is sprake van een krimpende werkgelegenheid en de vervangingsvraag is naar verwachting erg laag. Bij vier opleidingen is sprake van een matig perspectief. Het HAVO en het VWO worden gekenmerkt door een relatief lage vervangingsvraag en een relatief hoge arbeidsmarktinstroom van schoolverlaters. Het opleidingstype VBO landbouw en natuurlijke omgeving kent met name een laag aantal baanopeningen. De opleidingstypen Basisonderwijs en VBO horeca en levensmiddelentechniek kennen zowel een laag aantal baanopeningen als een hoge instroom van schoolverlaters. 
Tabel 4.15

Opleidingstypen met redelijk tot slechte arbeidsmarktperspectieven in Limburg in 2002

$\begin{array}{lll}\text { Opleidingstype } & \text { ITA typering }\end{array}$

VBO administratie, handel en textiel

Basisonderwijs

VBO landbouw en natuurlijke omgeving

HAVO/VWO

VBO horeca en levensmiddelentechniek

VBO verzorging

VBO motorvoertuigentechniek

MAVO

MBO sociaal-cultureel

\section{1,28}

1,14

1,12

1,09

1,05

1,04

1,02

1,00

1,00
slecht
matig
matig
matig
matig
redelijk
redelijk
redelijk
redelijk

\section{Bron: ROA}

Drie opleidingstypen waarvoor de arbeidsmarktperspectieven voor nieuwkomers matig zijn, zijn niet in tabel 4.15 opgenomen, vanwege het geringe aantal werkenden met deze opleidingsachtergrond in Limburg. Dit zijn de opleidingen VBO grafische techniek en de $\mathrm{MBO} /$ Leerlingwezen-opleidingen beweging en therapie en toerisme en recreatie.

\section{Knelpunten in de personeelsvoorziening}

Wanneer de arbeidsmarktperspectieven voor nieuwkomers met een bepaalde opleiding (zeer) goed zijn, dan is het voor deze werkzoekenden betrekkelijk gemakkelijk een baan te vinden die goed aansluit bij de opleiding. Dit betekent echter dat het voor werkgevers moeilijk zal zijn een geschikte kandidaat te vinden die een opleidingsachtergrond heeft die goed aansluit bij de functie-eisen. Met andere woorden: een (zeer) goed arbeidsmarktperspectief betekent (zeer) grote knelpunten in de personeelsvoorziening. Omgekeerd impliceert een matig tot slecht perspectief dat er (vrijwel) geen knelpunten zullen optreden.

De Indicator Toekomstige Knelpunten in de Personeelsvoorziening (ITKP) geeft een indicatie van de problemen die werkgevers naar verwachting in de personeelsvoorziening zullen ondervinden. Zoals in paragraaf 3.1 werd aangegeven wijkt deze indicator alleen af van de ITA wanneer een opleidingstype te kampen heeft met een krimpende werkgelegenheid. In dat geval zullen bedrijven de mogelijkheid aangrijpen om de gedwongen uitstroom van het zittende personeel af te remmen waardoor de vereiste instroom van schoolverlaters lager wordt en de knelpunten in de personeelsvoorziening nog verder afnemen. Wanneer het aanbod kleiner is dan de vraag en de ITKP dus kleiner is dan 1,00 , dan worden de knelpunten als groot getypeerd. Als de waarde kleiner is dan 0,85 dan wordt gesproken van zeer grote knelpunten. Wanneer de ITKP daarentegen groter is dan 1,00 , maar kleiner dan 1,05, wordt gesproken van enige knelpunten. Bij een hogere waarde van de ITKP wordt gesproken van vrijwel geen, of als de ITKP zelfs groter is dan 1,15, van 
geen knelpunten.

Als gevolg van de verwachte krapte op de Limburgse arbeidsmarkt, worden voor een groot deel van de opleidingstypen grote tot zeer grote knelpunten in de personeelsvoorziening in 2002 verwacht. Voor 36 van de 52 onderscheiden opleidingstypen (69\%) zal naar verwachting sprake zijn van grote tot zeer grote knelpunten. De problemen spitsen zich toe op het MBO/Leerlingwezen-niveau, waar voor maar liefst 31 van de 35 opleidingstypen $(90 \%)$ grote tot zeer grote knelpunten in de personeelsvoorziening worden verwacht. Aangezien de ITKP en de ITA alleen verschillen wanneer er sprake is van een krimpende werkgelegenheid, is het niet verassend dat een overzicht van de opleidingen met zeer grote knelpunten in 2002 een vrijwel identiek beeld oplevert als uit tabel 4.14 naar voren komt. De opleidingstypen waarvoor de knelpunten naar verwachting het grootst zullen zijn, bieden tevens de beste perspectieven voor schoolverlaters. Een uitzondering vormt de opleiding MBO/LLW geld, bank en belastingen. Ondanks het feit dat er sprake is van een krimp in de werkgelegenheid, is het arbeidsmarktperspectief van deze opleiding zeer goed. Aangezien de werkgever deze krimp kan gebruiken om de vraag naar nieuwkomers te verminderen, worden de knelpunten in de personeelsvoorziening niet als zeer groot, maar als groot getypeerd.

Kwalitatief onderzoek van het ETIL wijst in dezelfde richting ${ }^{62}$. Intermediairs geven aan dat ze voor Limburg een tekort aan middelbaar technisch opgeleide arbeidskrachten verwachten. Daarbij verwachten ze dat Limburg zwaarder onder deze arbeidsmarktkrapte zal lijden dan Nederland als geheel vanwege een snellere vergrijzing en een relatief grote industriële sector, waarin veel lager en middelbaar technisch personeel werkzaam is. De industrie kampt bovendien met een slecht imago bij de nieuwkomers en ondervindt daardoor extra moeilijkheden in de personeelsvoorziening. Vanuit de handel worden problemen verwacht in de personeelsvoorziening voor vakspecifieke verkopers en middenkader personeel met commerciële en leidinggevende kwaliteiten. Daarbij wordt aangeven dat deze sector het lastig vindt jongeren aan te trekken. De intermediairs verwachten overigens dat de arbeidsmarkt zal anticiperen op de verwachte knelpunten. Verwacht wordt dat de opleidingseisen ruimer gedefinieerd zullen worden en de leeftijds- en ervaringseisen minder star zullen worden onder druk van het aanbodtekort.

Daarnaast worden er door de intermediairs mogelijke oplossingen aangedragen. In de industrie wordt daarbij gedacht aan het stimuleren van de instroom in het technisch onderwijs (bijvoorbeeld door de financiële waardering van technische beroepen te verhogen en het imago van de industrie te verbeteren), het daadwerkelijk bevorderen van de aansluiting tussen onderwijs en arbeidsmarkt (bijvoorbeeld door middel van een meer pragmatische opleiding in de praktijk) en het bewuster voeren van een actief personeelsbeleid. In de handel wordt gewezen op het meer richten van het onderwijs op

62. Van Camp, H., 1997d, op. cit. 
werkhouding en communicatieve vaardigheden, het minder star hanteren van functie-eisen door bedrijven, het accent meer leggen op vraaggerichte scholing door Arbeidsvoorziening en het creëren van banenpools.

Naast de bovengenoemde instrumenten, laten recente ontwikkelingen op de Limburgse arbeidsmarkt zien dat bedrijven ook anderszins inspelen op de knelpunten in de personeelsvoorziening op de Limburgse arbeidsmarkt ${ }^{63}$. De verdergaande internationalisering en de daarmee gepaard gaande concurrentie uit het buitenland zal in toenemende mate leiden tot een streven naar een efficiënte werkwijze en naar de levering van die producten en diensten die de grootste toegevoegde waarde opleveren. De vraag naar nieuwkomers zou daardoor kunnen worden afgeremd. Daarnaast komt, bij toenemende knelpunten, een verplaatsing van (bepaalde) bedrijfsactiviteiten naar het buitenland steeds meer in het vizier. Daarnaast kan het werven van personeel in het (aangrenzende) buitenland soelaas bieden. Met name Belgisch personeel is daarbij, gezien de geringe cultuurverschillen en de beperkte taalproblemen, aantrekkelijk. Daarna komen Engeland en vervolgens Duitsland in beeld. Gezien het grotere belang van taal en cultuur in de dienstverlenende bedrijfssectoren zijn de wervingsmogelijkheden in het buitenland voor deze sectoren doorgaans beperkter dan voor de industriële sectoren.

Tabel 4.16

Opleidingstypen met (vrijwel) geen knelpunten in de personeelsvoorziening in Limburg in 2002

$\begin{array}{lll}\text { Opleidingstype } & \text { ITKP typering }\end{array}$

$\begin{array}{lcc}\text { VBO administratie, handel en textiel } & 1,46 & \text { geen } \\ \text { VBO landbouw en natuurlijke omgeving } & 1,36 & \text { geen } \\ \text { Basisonderwijs } & 1,33 & \text { geen } \\ \text { VBO Vervoer } & 1,15 & \text { vrijwel geen } \\ \text { VBO motorvoertuigentechniek } & 1,11 & \text { vrijwel geen } \\ \text { VBO horeca en levensmiddelentechniek } & 1,10 & \text { vrijwel geen } \\ \text { HAVONWO } & 1,09 & \text { vrijwel geen } \\ \text { VBO mechanische techniek } & 1,05 & \text { vrijwel geen }\end{array}$

Bron: ROA

In tabel 4.16 wordt een overzicht gegeven van de opleidingstypen waarvoor in 2002 (vrijwel) geen knelpunten in de personeelsvoorziening verwacht worden. Het gaat hier slechts om een beperkt aantal opleidingstypen. De verwachte krapte op de Limburgse arbeidsmarkt leidt ertoe dat voor een groot aantal opleidingstypen grote tot zeer grote knelpunten in de personeelsvoorziening worden verwacht. De tabel laat zien dat, naast het Basisonderwijs en HAVO/VWO, uitsluitend voor opleidingen op VBO-niveau geringe knelpunten in de personeelsvoorziening worden verwacht. Met name voor de opleidingstypen,

63. Zie Van Camp, H., 1997d, op. cit. 
Basisonderwijs, VBO landbouw en natuurlijke omgeving en VBO administratie, handel en textiel is er naar verwachting sprake van een ruime arbeidsmarkt. De opleidingstypen VBO motorvoertuigentechniek en VBO mechanische techniek worden gekenmerkt door een tekort aan nieuwkomers. Tegelijkertijd is er echter sprake van een krimpende werkgelegenheid. Aangezien werkgevers er in dat geval voor kunnen kiezen de vervangingsbehoefte te verminderen door zittende oudere werknemers in dienst te houden en de instroom van jongere nieuwkomers af te remmen, hoeft dit niet te leiden tot knelpunten in de personeelsvoorziening.

Drie opleidingstypen waarvoor de knelpunten in de personeelsvoorziening naar verwachting gering zullen zijn, zijn niet in tabel 4.16 opgenomen, vanwege het geringe aantal werkenden met deze opleidingsachtergrond in Limburg. Dit zijn de opleidingen VBO grafische techniek en de $\mathrm{MBO} /$ Leerlingwezen-opleidingen beweging en therapie en toerisme en recreatie.

\subsection{De arbeidsmarkt voor hoger opgeleiden tot 2002}

Hoger opgeleiden kennen een veel grotere (geografische) mobiliteit op de arbeidsmarkt dan lager en middelbaar opgeleiden. Bij het in kaart brengen van de regionale arbeidsmarkt voor hoger opgeleiden dient hiermee rekening te worden gehouden. Het arbeidsaanbod is immers slechts in relatief beperkte mate gebonden aan een specifieke regio. Enerzijds betekent dit dat werkgevers, indien zij geconfronteerd worden met rekruteringsproblemen, makkelijker nieuw personeel uit andere regio's kunnen werven. Anderzijds zullen werkzoekenden, wanneer zij geconfronteerd worden met een ruime (regionale) arbeidsmarkt, sneller kiezen voor het zoeken van een baan buiten de eigen regio.

Dit betekent dat het begrip 'regionaal arbeidsaanbod' voor hoger opgeleiden slechts een beperkte betekenis heeft. Bovendien zullen de regionale verschillen in de arbeidsmarktsituatie doorgaans geringer zijn dan bij de middelbare en lagere opleidingen. Dit betekent dat de landelijke indicatoren voor het toekomstig arbeidsmarktperspectief en voor de toekomstige knelpunten in de personeelsvoorzienig in feite goede maatstaven vormen voor de toekomstige situatie op de arbeidsmarkt voor hoger opgeleiden in Limburg. Wel kunnen de verwachte regionale ontwikkelingen aan de vraagzijde van de arbeidsmarkt - het aantal baanopeningen - in verhouding tot het landelijke beeld een indicatie geven van de mate waarin werkgevers in Limburg, vergeleken met het landelijke beeld, relatief veel of weinig knelpunten in de personeelsvoorziening zullen ervaren. Wanneer het aantal baanopeningen relatief hoog is zullen werkgevers in Limburg naar verwachting geconfronteerd worden met relatief grote knelpunten in de personeelsvoorziening vergeleken met het landelijk beeld. Wanneer daarentegen het aantal baanopeningen relatief laag is, zullen de toekomstige knelpunten, vergeleken met de rest van het land, kleiner zijn. Voor de nieuwkomers op de arbeidsmarkt betekent een relatief groot aantal baanopeningen in Limburg dat het arbeidsmarktperspectief in de eigen regio wat gunstiger is dan in de rest van het land. Een relatief klein aantal baanopeningen betekent daarentegen een minder goed perspectief voor de nieuwkomers op de Limburgse arbeidsmarkt. Als gevolg van dit 
mindere perspectief zullen werkzoekenden naar verwachting relatief vaak gedwongen worden buiten Limburg een baan te aanvaarden ${ }^{64}$.

Tabel 4.17

Landelijke Indicator Toekomstig Arbeidsmarktperspectief (ITA) en het verwachte percentage baanopeningen voor Nederland en Limburg tot 2002

Opleidingstype

ITA typering

baanopeningen

Nederland Limburg

$\% \quad \%$

HBO lerarenopleiding basisonderwijs

0,87

$\mathrm{HBO}$ lerarenopleiding talen

0,96

HBO lerarenopleiding natuur en techniek

0,86

$\mathrm{HBO}$ lerarenopleiding economie en maatschappij

0,85

$\mathrm{HBO}$ lerarenopleiding expressie

0,98

HBO laboratorium

0,96

$\mathrm{HBO}$ werktuigbouwkunde

0,88

HBO elektrotechniek

0,93

HBO informatica

0,85

$\mathrm{HBO}$ verpleegkunde

0,87

HBO (fysio)therapie

0,92

HBO accountancy en bedrijfseconomie

0,95

HBO bedrijfskunde

0,97

HBO maatschappelijk werk en hulpverlening

0,97

HBO uitvoerende en beeldende kunsten

0,95

WO wiskunde en natuurwetenschappen

0,94

WO (dier)geneeskunde

0,96

WO econom(etr)ie

0,87

WO rechten en bestuurskunde

0,97

WO sociale wetenschappen

0,95

$\begin{array}{rrr}\text { goed } & 30 & 28 \\ \text { goed } & 27 & 24 \\ \text { goed } & 26 & 27 \\ \text { zeer goed } & 37 & 33 \\ \text { goed } & 27 & 30 \\ \text { goed } & 24 & 18 \\ \text { goed } & 37 & 31 \\ \text { goed } & 28 & 25 \\ \text { zeer goed } & 41 & 37 \\ \text { goed } & 39 & 28 \\ \text { goed } & 40 & 35 \\ \text { goed } & 38 & 33 \\ \text { goed } & 45 & 38 \\ \text { goed } & 31 & 28 \\ \text { goed } & 40 & 33 \\ \text { goed } & 30 & 34 \\ \text { goed } & 22 & 23 \\ \text { goed } & 58 & 52 \\ \text { goed } & 32 & 30 \\ \text { goed } & 40 & 42\end{array}$

Bron: ROA

In tabel 4.17 wordt een overzicht gegeven van het verwachte arbeidsmarktperspectief voor hoger opgeleiden op de Nederlandse arbeidsmarkt ${ }^{65}$. De tabel laat zien dat voor alle opleidingstypen de indicator kleiner is dan één. Het aantal baanopeningen zal het aanbod derhalve overtreffen. Het arbeidsmarktperspectief voor de afgestudeerden is goed tot zeer goed. De tabel laat echter tevens zien dat voor een groot deel van de opleidingstypen het percentage baanopeningen in Limburg naar verwachting lager zal zijn dan in de rest van het land. Het verschil is het grootst bij de opleidingstypen HBO laboratorium, HBO werktuigbouwkunde, $\mathrm{HBO}$ verpleegkunde, $\mathrm{HBO}$ bedrijfskunde en $\mathrm{HBO}$ uitvoerende en

64. Dit is overigens alleen het geval bij een gelijkmatige spreiding van het aanbod over de verschillende regio's.

65. In de tabel zijn alleen die opleidingstypen opgenomen die gekenmerkt worden door het feit dat er in Limburg meer dan 2.000 mensen werkzaam zijn. 
beeldende kunsten. Aan dit beeld ligt met name de verwachting ten grondslag dat het upgradingsproces van de opleidingenstructuur van de werkgelegenheid in Limburg wat trager zal verlopen dan in de rest van het land, zoals tabel 1.6 van dit rapport reeds liet zien. Als gevolg hiervan zal de uitbreidingsvraag voor hoger opgeleiden in Limburg naar verwachting lager zijn dan in de rest van het land. Het industriële karakter van de Limburgse werkgelegenheid speelt hierbij een belangrijke rol. Het gemiddelde opleidingsniveau van de werkgelegenheid in de dienstensector is namelijk aanzienlijk hoger dan in de industriële sector. Het arbeidsmarktperspectief voor hoger opgeleiden zal over het algemeen in Limburg derhalve iets minder goed zijn dan in de rest van het land. De belangrijkste uitzondering op dit beeld vormt de opleiding WO wiskunde en natuurwetenschappen. Aangezien het percentage baanopeningen voor dit opleidingstype naar verwachting in Limburg groter zal zijn dan in de rest van het land, zal het perspectief voor nieuwkomers met dit opleidingstype in Limburg wat beter zijn dan in de rest van het land. Dit zal versterkt worden door het feit dat de arbeidsmarktinstroom van afstudeerders met deze opleidingsachtergrond op de Limburgse arbeidsmarkt zeer gering is vanwege het vrijwel ontbreken van universitaire opleidingen in deze studierichting in de provincie Limburg.

Een goed perspectief voor nieuwkomers heeft, zoals al eerder gezegd, een belangrijke keerzijde. Wanneer het arbeidsmarktperspectief voor nieuwkomers naar verwachting goed zal zijn, zullen werkgevers naar verwachting geconfronteerd worden met grote knelpunten in de personeelsvoorziening. De cijfers in tabel 4.17 impliceren derhalve dat werkgevers de komende jaren problemen zullen ondervinden bij het werven van hoger opgeleiden. Echter, aangezien de vraag naar hoger opgeleiden relatief gezien wat achterblijft bij de vraag in de rest van het land, zullen de knelpunten naar verwachting in Limburg over het algemeen met uitzondering van met name de opleiding WO wiskunde en natuurwetenschappen - wat minder groot zijn. 


\section{$5.1 \quad$ Inleiding}

In dit hoofdstuk zal de arbeidsmarktinformatie uit de voorgaande hoofdstukken worden gepresenteerd vanuit het perspectief van de bedrijfssector. Daarbij zal in de paragrafen 5.2 en 5.3 achtereenvolgens voor de handel en de industrie in de vorm van zogenaamde sectorfiches een beeld worden geschetst van de omvang en samenstelling van de werkgelegenheid, de actuele discrepanties tussen vraag en aanbod, de toekomstige werkgelegenheidsontwikkeling en de op korte en middellange termijn te verwachten knelpunten in de personeelsvoorziening. Bij de industrie zal een verdere verbijzondering plaatsvinden naar de voedings- en genotsmiddelenindustrie (paragraaf 5.3.1), de overige industrie (paragraaf 5.3.2), de chemie (paragraaf 5.3.3) en de metaalindustrie (paragraaf 5.3.4). Dit hoofdstuk wordt in paragraaf 5.3 .5 afgesloten met een nadere analyse van de moeilijk vervulbare vacatures in de industrie.

\subsection{Handel}

\section{Actuele werkgelegenheid}

In Limburg zijn 54.000 mensen in de groot- en detailhandel werkzaam. Tabel 5.1 laat zien dat dit 12,4 procent van de werkzame Limburgse beroepsbevolking is. Hiermee neemt de Limburgse handelssector een iets kleinere plaats in dan landelijk. Met name de relatief geringe omvang van de sector in het zuidelijk deel van de provincie ligt aan de geringe omvang ten grondslag, al blijft ook in Noord- en Midden-Limburg het werkgelegenheidsaandeel achter bij het belang van de handel in de rest van Nederland.

Tabel 5.1

Aandeel handel in totale werkgelegenheid in procenten, gemiddelde 1995-1996

Regio $\quad \%$

Limburg

Noord- en Midden-Limburg $\quad 13,0$

Zuid-Limburg $\quad 12,2$

Nederland $\quad 14,1$

Bron: CBS/ROA

Tabel 5.2 laat zien dat er in de handel relatief veel jongeren werkzaam zijn. In Limburg is $37 \%$ van de werkenden in de handel jonger dan 30 jaar, terwijl gemiddeld genomen het werkgelegenheidsaandeel van de jongeren slechts ongeveer een kwart van het totaal aantal werkenden is. Landelijk liggen beide percentages iets hoger. Ook het percentage vrouwen ligt relatief hoog. Bijna de helft van de werkenden in de handel is vrouw, terwijl slechts $36 \%$ van de totale werkende Limburgse beroepsbevolking vrouw is. Landelijk is het verschil 
tussen de handel en de totale werkzame beroepsbevolking overigens veel kleiner. Deeltijdarbeid speelt in de handel een relatief belangrijke rol. Bijna eenderde van de arbeidskrachten in de Limburgse handel werkt 32 uur of minder. Daarbij zijn de scholieren en studenten die een bijbaan van slechts enkele uren per week hebben overigens buiten beschouwing gelaten. Van de totale werkzame beroepsbevolking in Limburg werkt slechts één kwart in deeltijd.

Tabel 5.2

Samenstelling van de werkgelegenheid in procenten, gemiddelde 1995-1996

\begin{tabular}{llllll}
\hline & $\begin{array}{l}\text { jongeren } \\
\%\end{array}$ & $\begin{array}{l}\text { ouderen } \\
\%\end{array}$ & $\begin{array}{l}\text { vrouwen } \\
\%\end{array}$ & $\begin{array}{l}\text { flexibel werk } \\
\%\end{array}$ & $\begin{array}{l}\text { deeltijdarbeid } \\
\%\end{array}$ \\
\hline Handel in Limburg & 37 & 14 & 47 & 6 & 31 \\
Limburg totaal & 26 & 16 & 36 & 8 & 25 \\
& 40 & 13 & 42 & 8 & 28 \\
Handel in Nederland & 49 & 15 & 37 & 8 & 27 \\
\hline
\end{tabular}

Bron: CBS/ROA

Tabel 5.3 geeft een indicatie van het kwalificatieniveau van de werkenden. Het gemiddeld opleidingsniveau van de werkenden in de handel blijkt in Limburg iets lager te zijn dan het gemiddeld opleidingsniveau in de andere bedrijfssectoren. In de Limburgse handel is het aandeel van VBO'ers en MBO'ers hoger dan het Limburgs gemiddelde. Het werkgelegenheidsaandeel van de HBO'ers is daarentegen wat lager. Het verschil met het landelijke beeld is opvallend. Terwijl in Limburg de helft van de werkenden in de handel een MBO-achtergrond heeft, is dit landelijk slechts $28 \%$ procent. Het werkgelegenheidsaandeel van de VBO'ers is daarentegen landelijk veel hoger. In Limburg heeft slechts $31 \%$ van de werkenden een VBO-achtergrond; landelijk bedraagt dit percentage maar liefst 52.

Tabel 5.3

Samenstelling van de werkgelegenheid naar opleidingsniveau in procenten, gemiddelde 1995-1996

\begin{tabular}{llllll}
\hline & $\begin{array}{l}\text { Basis } \\
\%\end{array}$ & $\begin{array}{l}\text { VBO } \\
\%\end{array}$ & $\begin{array}{l}\text { MBO } \\
\%\end{array}$ & $\begin{array}{l}\text { HBO } \\
\%\end{array}$ & $\begin{array}{l}\text { WO } \\
\%\end{array}$ \\
\hline $\begin{array}{l}\text { Handel in Limburg } \\
\text { Limburg totaal }\end{array}$ & 8 & 31 & 50 & 9 & - \\
Handel in Nederland & 9 & 24 & 44 & 17 & 5 \\
Nederland totaal & 9 & 52 & 28 & 9 & 2 \\
& 8 & 22 & 44 & 18 & 7 \\
\hline
\end{tabular}

Bron: CBS/ROA 


\section{Actuele discrepanties}

In tabel 5.4 wordt een indicatie gegeven van de rekruteringsproblemen die werkgevers in de handel op de Limburgse arbeidsmarkt ondervinden. De vacaturegraad is in de handel met 24 vacatures per 1.000 werkenden relatief hoog. Dit betekent niet noodzakelijkerwijs dat in de handel de problemen om geschikte mensen te vinden relatief groot zijn. Een hoge vacaturegraad geeft echter wel aan dat het relatief grote inspanningen vergt om te voorzien in de rekruteringsbehoefte, vanwege het grote aantal nieuwkomers dat bedrijven in de handel moeten aantrekken als gevolg van de groei in de werkgelegenheid of de vervangingsbehoefte. Het percentage moeilijk vervulbare vacatures vormt een meer direct signaal voor het bestaan van rekruteringsproblemen in de handel. Tabel 5.4 laat zien dat in de handel een relatief klein percentage vacatures langer dan drie maanden openstaat.

De arbeidsmarktkrapte geeft aan hoeveel direct inzetbare werkzoekenden er volgens Arbeidsvoorziening Limburg beschikbaar zijn voor elke openstaande vacature in de handel. Uit de tabel blijkt dat er per 100 werkzoekenden 77 vacatures zijn. Hiermee neemt de handel een gemiddelde positie op de Limburgse arbeidsmarkt in.

Tabel 5.4

Indicatoren voor de actuele discrepanties in de handel, voorjaar 1997

\begin{tabular}{llll}
\hline & Limburg & handel & typering \\
\hline & & & \\
Vacaturegraad (aantal vacatures per 1000 werkenden) & 19 & 24 & hoog \\
Percentage moeilijk vervulbare vacatures & 25 & 19 & laag \\
Indicator arbeidsmarktkrapte & 0,77 & 0,77 & gemiddeld \\
\hline
\end{tabular}

Bron: Arbeidsvoorziening Limburg/CBS/ROA

Uit het onderzoek van het ETIL blijkt dat vooral de grote vraag naar jongeren, als gevolg van de ontgroening van de beroepsbevolking, tot steeds grotere knelpunten in de personeelsvoorziening leidt. Daarbij kan in het bijzonder gewezen worden op het afnemend aantal studenten, die vaak een bijbaantje in de handel hebben. Daarnaast worden door werkgevers steeds hogere eisen gesteld; eisen waaraan het aanbod op dit moment niet kan voldoen. Het gaat hierbij om de bereidheid om te blijven leren, een positieve werkhouding, communicatieve vaardigheden en een klantgerichte instelling. In het bijzonder wordt in de handel gewezen op de combinatie van commerciële vaardigheden en specialistische kennis die voor verkoopadviserende werkzaamheden verlangd wordt. Werkgevers wijzen daarnaast vooral op een gebrek aan werkervaring bij de potentiële arbeidskrachten. Een probleem waarmee de handel specifiek geconfronteerd wordt, is het toenemend belang van part-time banen, mede als gevolg van de verruimde openingstijden. Werkzoekenden zijn daarentegen vaak op zoek naar een full-time baan. Ten slotte kampt de handel met een imago-probleem op de arbeidsmarkt, wat vooral veroorzaakt wordt door de slechte arbeidsvoorwaarden en de geringe investeringen in aanvullende scholing. 
Bij het zoeken naar mogelijke oplossingen dient rekening te worden gehouden met het specifieke karakter van de sector. De kleinschaligheid van een groot deel van de bedrijven in met name de detailhandel leidt ertoe dat bedrijven moeilijk via interne scholing en doorstroming van personeel naar hogere functies hun rekruteringsproblemen kunnen bestrijden. Bij oplossingen voor de kwalitatieve aansluitingsproblemen op de arbeidsmarkt in de sector handel kan vooral gedacht worden aan het meer richten van het onderwijs op aspecten als de werkhouding en de communicatieve vaardigheden en het minder star hanteren van functie-eisen door bedrijven, het accent meer leggen op vraaggerichte scholing door Arbeidsvoorziening en het creëren van banenpools.

\section{Beroepsgroepen en opleidingstypen}

Tabel 5.4 liet zien dat de rekruteringsproblemen in de handel met name hun oorsprong vinden in de hoge vacaturegraad. Uit tabel 5.5, waarin een overzicht wordt gegeven van de actuele discrepanties voor de belangrijkste beroepsgroepen in de handel, blijkt dat de vacaturegraad met name hoog is voor de verkopers en de commercieel employés. De tabel illustreert tevens dat, hoewel de gemiddelde arbeidsmarktkrapte in de handel niet uitzonderlijk groot is, in specifieke segmenten de tekorten nijpend zijn. Dit is met name het geval bij de bedrijfsleiders, die $13 \%$ van de totale werkgelegenheid in de handel vormen. Deze krapte uit zich bovendien in een hoog percentage moeilijk vervulbare vacatures.

Tabel 5.5

Actuele arbeidsmarktindicatoren belangrijkste beroepsgroepen in de handel, voorjaar 1997

\begin{tabular}{lclll} 
Beroepsgroep & $\begin{array}{r}\text { aandeel } \\
\text { werkgelegenheid } \\
\%^{1}\end{array}$ & $\begin{array}{l}\text { vacature- } \\
\text { graad }\end{array}$ & $\begin{array}{l}\text { percentage moeilijk } \\
\text { vervulbare vacatures }\end{array}$ & $\begin{array}{l}\text { arbeidsmarkt- } \\
\text { krapte }\end{array}$ \\
\hline Verkopers & 23 & hoog & gemiddeld & 0,97 \\
Bedrijfsleiders & 13 & laag & erg hoog & 1,10 \\
Commercieel medewerkers & 8 & - & - & 0,59 \\
Commercieel employés & 8 & hoog & gemiddeld & 0,36 \\
Boekhouders en secretaresses & 6 & gemiddeld & gemiddeld &
\end{tabular}

\footnotetext{
1. Gebaseerd op landelijke cijfers.

Bron: CBS/Arbeidsvoorziening Limburg/ROA
}

In tabel 5.6 wordt een overzicht gegeven van de belangrijkste opleidingsachtergronden van de werkenden in de handel. De richting 'handel' op MBO/Leerlingwezen-niveau blijkt, zoals verwacht mocht worden, de belangrijkste vakopleiding voor de bedrijfssector. In de handel heeft $18 \%$ van de werkenden deze opleidingsachtergrond. Uit de tabel blijkt tevens dat de vraag naar personeel met deze opleidingsachtergrond voor de grootste rekruteringsproblemen zorgt. De vacaturegraad is hoog; er zijn relatief veel openstaande vacatures per werkende. Daarbij is er sprake van een krappe arbeidsmarkt. Voor ruim tweeëneenhalve vacature is slechts één direct inzetbare werkzoekende beschikbaar. Voor 
de overige relevante opleidingstypen voor de handel, waaronder de algemene opleidingen MAVO, HAVO en VWO, wijken de discrepanties niet af van het gemiddelde Limburgse beeld.

Tabel 5.6

Actuele arbeidsmarktindicatoren belangrijkste opleidingstypen in de handel, voorjaar 1997

\begin{tabular}{lrlll}
\hline Opleidingstype & $\begin{array}{r}\text { aandeel } \\
\text { werkgelegenheid } \\
\%^{2}\end{array}$ & $\begin{array}{l}\text { vacature- } \\
\text { graad }\end{array}$ & $\begin{array}{l}\text { percentage moeilijk } \\
\text { vervulbare vacatures }\end{array}$ & $\begin{array}{l}\text { indicatie } \\
\text { arbeidsmarkt- } \\
\text { krapte }\end{array}$ \\
\hline MBO/LLW handel & 16 & hoog & gemiddeld & 2,56 \\
MAVO & 10 & gemiddeld & gemiddeld & 0,16 \\
HAVO/NWO & 7 & gemiddeld & gemiddeld & 0,14 \\
MBO/LLW administratie & 6 & gemiddeld & gemiddeld & 0,29 \\
VBO verzorging & 5 & gemiddeld & gemiddeld & 0,22 \\
\hline
\end{tabular}

${ }^{2}$ Gebaseerd op landelijke cijfers

Bron: CBS/Arbeidsvoorziening Limburg/ROA

Nadere typering moeilijk vervulbare vacatures in de handel

In de telefonische enquête en de diepte-interviews wordt door werkgevers in de handel aangegeven dat met name in de volgende beroepsgroepen vacatures moeilijk vervulbaar $z_{i j n}{ }^{66}$ :

- algemeen medewerker (in- en extern);

- algemeen verkoopmedewerker (binnen- en buitendienst);

- verkoopmedewerker specifiek;

- elektromonteurs;

- verkoopchef en verkoopleider;

- drogist;

- VBO chauffeurs;

- middelbare technische functies;

- middelbare commerciële employés;

- meet- en regeltechnici.

Voor een aantal van deze beroepsgroepen kan aan de hand van de enquête en de interviews een dieper inzicht in de aansluitingsproblematiek verkregen worden.

\section{algemeen medewerker (intern)}

opleiding

ervaring

leeftijd
VBO-diploma of lerend voor MAVO-HAVO-VWO of MBO diploma geen afhankelijk van werk (vast magazijnwerk versus vakkenvullen) vooral

66. Zie Van Camp, H., 1997a, op.cit. en Van Camp, H., 1997b, op.cit. 
jongeren; de leeftijdseisen voor vast magazijnwerk zijn minder vast dan voor vakkenvullers;

pers.kenmerk inzet

essentiële eis inzet

algemeen medewerker (extern)

opleiding VBO-diploma of van MAVO-HAVO-VWO, MBO; de benodigde hoogte van het diploma is afhankelijk van de doorstroommogelijkheden dat een bedrijf op het oog heeft met de net in dienst getredene;

ervaring bekendheid met het te verhandelen product

leeftijd 20-25 jaar

pers. kenmerk inzet, communicatief, representatief, zekere talenkennis welke afhankelijk is van de bedrijfsrelaties met buitenlandse klanten

essentiële eis klantgerichtheid (zie persoonskenmerken)

algemene verkoopmedewerker binnendienst c.q. winkel

opleiding VBO diploma en goed Nederlands spreken

ervaring

leeftijd geen, wel een zekere mate van productkennis

17 tot maximaal 21 jaar in de detailhandel; bij de groothandel liggen deze leeftijdseisen ruimer

pers. kenmerk collegialiteit, inzet, feeling met het product, representatief

essentiële eis inzet en positieve werkhouding

algemene verkoopmedewerker buitendienst

opleiding VBO-MBO diploma met mogelijk een specifieke talenkennis

ervaring

leeftijd productkennis van het bedrijf

pers. kenmerk

20-25 jaar tot maximaal 30 jaar als instroomleeftijd

essentiële eis

klantgerichtheid, collegialiteit

klantgerichtheid en productkennis

verkoopmedewerker vakspecifiek

opleiding VBO-diploma of MAVO-HAVO diploma als instroomniveau voor vervolg brancheopleiding of MBO-MMO-MDS diploma

ervaring geen

leeftijd tot 35 jaar

pers. kenmerk klantgericht en deskundig, gemotiveerde vakgenoot, klantgericht

essentiële eis vakkennis

elektromonteurs 


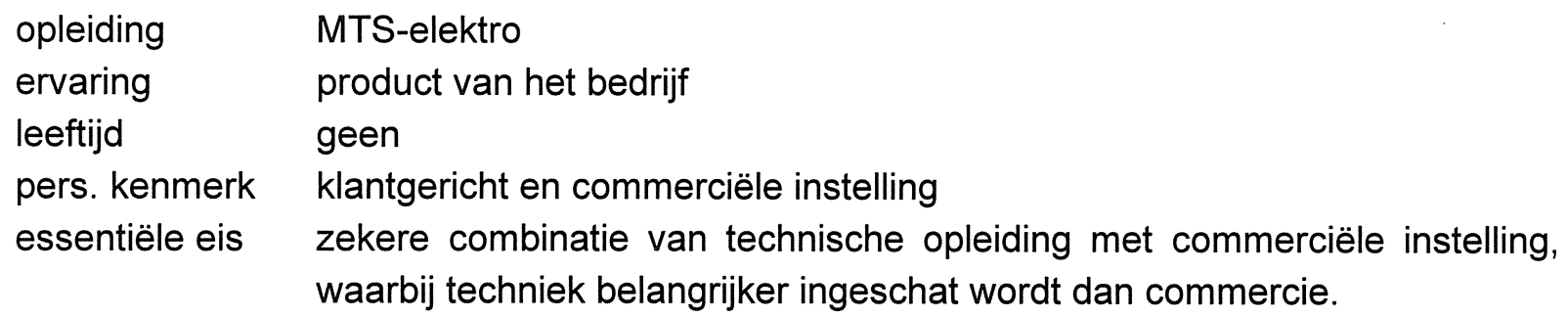

Tabel 5.7 laat zien dat de werkgelegenheid in de handel zich de komende jaren naar verwachting gunstig zal ontwikkelen. Zowel op de korte termijn (1998) als de middellange termijn (tot 2002) wordt in de Limburgse handel een werkgelegenheidtoename verwacht die aanzienlijk groter zal zijn dan de gemiddelde werkgelegenheidsgroei in de provincie. Een vergelijking met het landelijke beeld laat zien dat de Limburgse handel naar verwachting relatief sterk zal groeien vergeleken met de handelssector in de rest van het land. 
Tabel 5.7

Uitbreidingsvraag in 1998 en tot 2002 in jaarlijkse groeipercentages

\begin{tabular}{lll}
\hline & $\begin{array}{l}1998 \\
\%\end{array}$ & $\begin{array}{l}1997-2002 \\
\%\end{array}$ \\
\hline Handel in Limburg & 2,7 & 2,6 \\
Limburg totaal & 1,7 & 1,6 \\
Handel in Nederland & - & 2,2 \\
Nederland totaal & - & 1,7 \\
\hline
\end{tabular}

Bron: TNO/Inro/CPB/ROA

Het verwachte aantal baanopeningen voor nieuwkomers als percentage van de huidige werkgelegenheid geeft een indicatie van de inspanningen de werkgevers zich in de (nabije) toekomst zullen moeten getroosten om nieuwe arbeidskrachten aan te trekken. Baanopeningen ontstaan, zoals reeds eerder werd opgemerkt, enerzijds als gevolg van een groeiende werkgelegenheid (uitbreidingsvraag) en anderzijds als gevolg van het (vervroegd) uittreden van werkenden of als gevolg van beroepsmobiliteit (vervangingsvraag). In tabel 5.8 wordt een overzicht gegeven van het percentage baanopeningen voor de belangrijkste beroepsgroepen in de handel. Uit de tabel blijkt dat met name in 1998 het percentage baanopeningen in de voor de handel relevante beroepsgroepen relatief hoog zal zijn. Zo is het aantal baanopeningen voor de verkopers - de grootste beroepsgroep in de handel - 6,3 procent van de huidige werkgelegenheid voor deze beroepsgroep. Op de middellange termijn zal de jaarlijkse vraag naar nieuwkomers bij de meeste beroepsgroepen in de handel enigszins dalen. De baanopeningen voor verkopers zullen bijvoorbeeld dalen van $6,3 \%$ naar gemiddeld $5,1 \%$ per jaar. Alleen de vraag naar boekhouders en secretaresses zal, ondanks de lichte afname van 7,2 naar gemiddeld $6,3 \%$, naar verwachting relatief hoog blijven.

Tabel 5.8

Toekomstige werkgelegenheidsontwikkeling belangrijkste beroepsgroepen in de handel (in procenten van het aantal werkenden)

\begin{tabular}{lclll}
\hline Beroepsgroep & $\begin{array}{c}\text { baanopeningen } \\
1998 \\
\%\end{array}$ & typering & $\begin{array}{c}\text { baanopeningen } \\
1997-2002 \\
\%\end{array}$ & typering \\
& & & & \\
Verkopers & 6,3 & hoog & 5,1 & gemiddeld \\
Bedrifsleiders & 3,7 & gemiddeld & 3,8 & gemiddeld \\
Commercieel medewerkers & 5,5 & hoog & 5,5 & gemiddeld \\
Commercieel employés & 4,4 & gemiddeld & 3,7 & gemiddeld \\
Boekhouders en secretaresses & 7,2 & hoog & 6,3 & hoog \\
\hline
\end{tabular}

Bron: ROA

Tabel 5.9 laat zien dat de rekruteringsproblemen voor de belangrijkste opleidingstypen in de 
handel in 1998 naar verwachting beperkt zullen zijn. De Indicator Toekomstige Knelpunten in de Personeelsvoorziening (ITKP) geeft, zoals gezegd, de verhouding weer tussen enerzijds de momenteel reeds openstaande vacatures en de toekomstige baanopeningen en anderzijds de direct inzetbare werkzoekenden en de verwachte instroom van schoolverlaters op de arbeidsmarkt. De tabel laat zien dat in 1998 alleen voor de MBO/Leerlingwezenopleidingen enige knelpunten in de personeelsvoorziening verwacht worden. De tabel laat echter tevens zien dat op de middellange termijn de knelpunten in de handel aanzienlijk zullen toenemen. Voor de voor de handel belangrijke opleidingstypen MBO/LLW handel en $\mathrm{MBO} / \mathrm{LLW}$ administratie worden op de middellange termijn zelfs grote knelpunten verwacht. Ook bij de MAVO'ers zullen er enige knelpunten optreden. Alleen voor de opleidingstypen HAVO/VWO en VBO verzorging zullen de knelpunten naar verwachting gering zijn.

Tabel 5.9

Toekomstige knelpunten in de personeelsvoorziening voor de belangrijkste opleidingstypen in de handel

\begin{tabular}{lllll}
\hline Opleidingstype & $\begin{array}{l}\text { ITKP } \\
1998\end{array}$ & typering & $\begin{array}{l}\text { ITKP } \\
2002\end{array}$ & typering \\
\hline MBO/LLW handel & 1,00 & enige & 0,93 & groot \\
MAVO & 1,09 & vrijwel geen & 1,00 & enige \\
HAVO/VWO & 1,11 & vrijwel geen & 1,09 & vrijwel geen \\
MBO/LLW administratie & 1,00 & enige & 0,88 & groot \\
VBO verzorging & 1,11 & vrijwel geen & 1,08 & vrijwel geen \\
& & & &
\end{tabular}

Bron: ROA

Zoals hierboven reeds gesteld, dient bij het zoeken naar mogelijke oplossingen rekening te worden gehouden met het specifieke karakter van de sector. De gemiddeld genomen kleinschaligheid van de bedrijven in de detailhandel leidt ertoe dat bedrijven moeilijk via interne scholing en doorstroming rekruteringsproblemen kunnen bestrijden. Bovendien kunnen de rekruteringsproblemen worden versterkt door het imago-probleem waarmee de sector kampt, mede als gevolg van de geringe loopbaanmogelijkheden en het grote aantal zogenaamde 'dead end jobs'.

\subsection{Industrie}

\subsubsection{Voedings- en genotsmiddelenindustrie}

Actuele werkgelegenheid

In Limburg zijn iets meer dan 10.000 mensen werkzaam in de voedings- en genotsmiddelenindustrie. Zoals tabel 5.10 aangeeft loopt Limburg hiermee aardig in de pas met de rest van Nederland. De voedingsindustrie is met 1,9 procent van alle werkenden in Zuid-Limburg echter aanzienlijk kleiner dan in Noord- en Midden-Limburg, waar 2,6\% van de 
werkenden in deze sector emplooi vindt.

Tabel 5.10

Aandeel voedings- en genotsmiddelenindustrie in totale werkgelegenheid in procenten, gemiddelde 1995-1996

Regio $\%$

$\begin{array}{lr}\text { Limburg } & 2,4 \\ \text { Noord- en Midden-Limburg } & 2,6 \\ \text { Zuid-Limburg } & 1,9 \\ \text { Nederland } & 2,6\end{array}$

Bron: CBS/ROA

Tabel 5.11 laat zien dat er in de voedings- en genotsmiddelenindustrie relatief veel jongeren werkzaam zijn. Wat dit betreft is er overigens vrijwel geen verschil tussen Limburg en de rest van Nederland.

In de voedings- en genotsmiddelenindustrie zijn relatief weinig vrouwen werkzaam. Het werkgelegenheidsaandeel van vrouwen in de voedings- en genotsmiddelenindustrie ligt in Limburg net boven het landelijk gemiddelde.

Tabel 5.11

Samenstelling van de werkgelegenheid in procenten, gemiddelde 1995-1996

\begin{tabular}{lccccc}
\hline & $\begin{array}{c}\text { jongeren } \\
\%\end{array}$ & $\begin{array}{c}\text { ouderen } \\
\%\end{array}$ & $\begin{array}{c}\text { vrouwen } \\
\%\end{array}$ & $\begin{array}{c}\text { flexibel werk } \\
\%\end{array}$ & $\begin{array}{c}\text { deeltijdarbeid } \\
\%\end{array}$ \\
\hline Voedingsind. in Limburg & 33 & - & 29 & - & - \\
Limburg totaal & 26 & 16 & 36 & 8 & 16 \\
Voedingsind. in Nederland & 34 & 13 & 28 & 8 & 27 \\
Nederland totaal & 29 & 15 & 37 & 8 & 10 \\
\hline
\end{tabular}

Bron: CBS/ROA

In tabel 5.12 zijn de werkenden in de voedings- en genotsmiddelenindustrie uitgesplitst naar opleidingsniveau. Ten opzichte van het landelijk gemiddelde zijn er erg weinig MBO'ers actief in de voedings- en genotsmiddelenindustrie in Limburg. Ook het percentage VBO'ers ligt in deze sector iets onder het landelijk gemiddelde. 
Tabel 5.12

Samenstelling van de werkgelegenheid naar opleidingsniveau in procenten, gemiddelde 1995-1996

\begin{tabular}{lccccc}
\hline & $\begin{array}{l}\text { Basis } \\
\%\end{array}$ & $\begin{array}{l}\text { VBO } \\
\%\end{array}$ & $\begin{array}{l}\text { MBO } \\
\%\end{array}$ & $\begin{array}{l}\text { HBO } \\
\%\end{array}$ & $\begin{array}{l}\text { WO } \\
\%\end{array}$ \\
\hline $\begin{array}{l}\text { Voedingsind. in Limburg } \\
\text { Limburg totaal }\end{array}$ & - & 29 & 33 & - & - \\
Voedingsind. in Nederland & 16 & 24 & 44 & 17 & 5 \\
Nederland totaal & 8 & 22 & 42 & 9 & 2 \\
Bron: CBS/ROA & & & & 18 & 7 \\
\end{tabular}

\section{Actuele discrepanties}

In tabel 5.13 wordt een indicatie gegeven van de rekruteringsproblemen die werkgevers in de voedings- en genotsmiddelenindustrie op de Limburgse arbeidsmarkt ondervinden. Zowel de vacaturegraad als het percentage moeilijk vervulbare vacatures ligt iets beneden het gemiddelde. De indicator arbeidsmarktkrapte geeft aan dat er momenteel in de voedingsindustrie voor elke 100 direct inzetbare werkzoekenden 71 vacatures beschikbaar zijn. Deze verhouding is relatief laag ten opzichte van de andere Limburgse sectoren. De voedings- en genotsmiddelenindustrie zal over het algemeen genomen derhalve niet al teveel problemen ondervinden bij het rekruteren van nieuwe arbeidskrachten.

Tabel 5.13

Indicatoren voor de actuele discrepanties in de voedings- en genotsmiddelenindustrie, voorjaar 1997

Limburg voedings- typering
industrie

$\begin{array}{llll}\text { Vacaturegraad (aantal vacatures per } 1000 \text { werkenden) } & 19 & 11 & \text { gemiddeld } \\ \text { Percentage moeilijk vervulbare vacatures } & 25 & 22 & \text { gemiddeld } \\ \text { Indicator arbeidsmarktkrapte } & 0,77 & 0,71 & \text { laag }\end{array}$

Bron: Arbeidsvoorziening Limburg/CBS/ROA

Beroepsgroepen en opleidingstypen

In tabel 5.14 zijn de vijf grootste beroepsgroepen in de voedings- en genotsmiddelenindustrie weergegeven. Uit deze tabel blijkt dat de vacaturegraad met name hoog is voor productiemedewerkers en verkopers. Verder blijkt dat vooral de vacatures voor productiemedewerkers vaak moeilijk te vervullen zijn. Verder blijkt dat de arbeidsmarkt voor verkopers krap is. Er zijn in deze beroepsgroep per 100 direct inzetbare werkzoekenden 97 vacatures. 
Tabel 5.14

Actuele arbeidsmarktindicatoren belangrijkste beroepsgroepen in de voedings- en genotsmiddelenindustrie, voorjaar 1997

\begin{tabular}{lrlll}
\hline Beroepsgroep & $\begin{array}{r}\text { aandeel } \\
\text { werkgelegenheid } \\
\%^{*}\end{array}$ & $\begin{array}{l}\text { vacature- } \\
\text { graad }\end{array}$ & $\begin{array}{l}\text { percentage moeilijk } \\
\text { vervulbare vacatures }\end{array}$ & $\begin{array}{l}\text { arbeidsmarkt- } \\
\text { krapte }\end{array}$ \\
\hline Mechanisch operators & 17 & - & - & - \\
$\begin{array}{l}\text { Procesoperators } \\
\text { Productiemedewerkers }\end{array}$ & 10 & gemiddeld & gemiddeld & 0,59 \\
Verkopers & 9 & hoog & hoog & 0,22 \\
Chauffeurs & 7 & hoog & gemiddeld & 0,97 \\
& 5 & gemiddeld & gemiddeld & 0,42 \\
\hline
\end{tabular}

* Gebaseerd op landelijke cijfers

Bron: CBS/Arbeidsvoorziening Limburg/ROA

In tabel 5.15 wordt een overzicht gegeven van de belangrijkste opleidingstypen in de werkgelegenheid in de voedings- en genotsmiddelenindustrie. Met 16 procent is Basisonderwijs het belangrijkste opleidingstype. In de voedingsindustrie heeft $6 \%$ van de werkenden de opleidingsachtergrond MBO/LLW handel. Uit de tabel blijkt dat de vraag naar personeel met deze opleidingsachtergrond voor de grootste rekruteringsproblemen zorgt. De vacaturegraad is hoog en er is sprake van een krappe arbeidsmarkt. Voor ruim tweeëneenhalve openstaande vacature is slechts één direct inzetbare werkzoekende beschikbaar. De andere genoemde opleidingstypen in de tabel nemen een gemiddelde positie in het Limburgs arbeidsmarktbeeld in.

Tabel 5.15

Actuele arbeidsmarktindicatoren belangrijkste opleidingstypen in de voedings- en genotsmiddelenindustrie, voorjaar 1997

\begin{tabular}{lllll}
\hline Opleidingstype & $\begin{array}{r}\text { aandeel } \\
\text { werkgelegenheid } \\
\%^{2}\end{array}$ & $\begin{array}{l}\text { vacature- } \\
\text { graad }\end{array}$ & $\begin{array}{l}\text { percentage moeilijk } \\
\text { vervulbare vacatures }\end{array}$ & $\begin{array}{l}\text { arbeidsmarkt- } \\
\text { krapte }\end{array}$ \\
\hline Basisonderwijs & 16 & - & - & - \\
MAVO & 8 & gemiddeld & gemiddeld & 0,18 \\
MBO/LLW handel & 6 & hoog & gemiddeld & 2,56 \\
MBO/LLW brood en banket & 5 & - & gemiddeld & 0,87 \\
VBO verzorging & 4 & gemiddeld & gemiddeld & 0,22 \\
\hline
\end{tabular}

${ }^{2}$ Gebaseerd op landelijke cijfers

Bron: CBS/Arbeidsvoorziening Limburg/ROA

Toekomstige werkgelegenheidsontwikkeling

Tabel 5.16 laat de werkgelegenheidsontwikkeling voor de voedings- en 
genotsmiddelenindustrie op korte en middellange termijn zien. Uit de tabel blijkt dat voor de voedingsindustrie in Limburg een relatief grote werkgelegenheidstoename op middellange termijn verwacht wordt vergeleken met het landelijk beeld. Verder geldt echter dat zowel op de korte als op de middellange termijn de verwachte werkgelegenheidstoename achter blijft bij de verwachte werkgelegenheidsgroei voor Limburg als geheel.

Tabel 5.16

Uitbreidingsvraag in 1998 en tot 2002 in jaarlijkse groeipercentages

\begin{tabular}{lll}
\hline & $\begin{array}{l}1998 \\
\%\end{array}$ & $\begin{array}{l}1997-2002 \\
\%\end{array}$ \\
\hline Voedingsindustrie in Limburg & 0,0 & 1,2 \\
Limburg totaal & 1,7 & 1,6 \\
Voedingsindustrie in Nederland & - & 0,4 \\
Nederland totaal & - & 1,7 \\
\hline
\end{tabular}

Bron: TNO/Inro/CPB/ROA

In tabel 5.17 wordt een overzicht gegeven van de baanopeningen als percentage van het aantal werkenden voor de grootste beroepsgroepen in de voedings- en genotsmiddelenindustrie. Vooral voor chauffeurs worden veel baanopeningen verwacht. Ook voor verkopers worden in 1998 veel baanopeningen verwacht. Op de middellange termijn zal het percentage baanopeningen voor verkopers met 5,1 procent echter iets lager liggen dan op de korte termijn.

Tabel 5.17

Toekomstige werkgelegenheidsontwikkeling belangrijkste beroepsgroepen in de voedings- en genotsmiddelenindustrie (in procenten van het aantal werkenden)

\begin{tabular}{|c|c|c|c|c|}
\hline Beroepsgroep & $\begin{array}{l}\text { baanopeningen } \\
1998 \\
\%\end{array}$ & typering & $\begin{array}{l}\text { baanopeningen } \\
1997-2002 \\
\%\end{array}$ & typering \\
\hline Mechanisch operators & 3,7 & gemiddeld & 3,0 & laag \\
\hline Procesoperators & 3,7 & gemiddeld & 3,5 & gemiddeld \\
\hline Productiemedewerkers & 2,9 & laag & 3,9 & gemiddeld \\
\hline Verkopers & 6,3 & hoog & 5,1 & gemiddeld \\
\hline Chauffeurs & 7,2 & hoog & 5,8 & hoog \\
\hline
\end{tabular}

Bron: ROA

Tabel 5.18 geeft voor de grootste opleidingstypen in de werkgelegenheid in de voedings- en genotsmiddelenindustrie aan in welke mate er knelpunten in de personeelvoorziening verwacht worden voor 1998 en 2002. Alleen voor MBO/LLW brood en banket worden op korte termijn grote knelpunten in de personeelsvoorziening verwacht. Op middellange termijn zullen de knelpunten in de personeelsvoorziening, met name op MBO-niveau, 
aanzienlijk groter worden.

Tabel 5.18

Toekomstige knelpunten in de personeelsvoorziening voor de belangrijkste opleidingstypen in de voedings- en genotsmiddelenindustrie

\begin{tabular}{lllll}
\hline Opleidingstype & $\begin{array}{l}\text { ITKP } \\
1998\end{array}$ & typering & $\begin{array}{l}\text { ITKP } \\
2002\end{array}$ & typering \\
& & & & \\
\hline Basisonderwijs & 1,11 & vrijwel geen & 1,33 & geen \\
MAVO & 1,09 & vrijwel geen & 1,00 & enige \\
MBO/LLW handel & 1,00 & enige & 0,93 & groot \\
MBO/LLW brood en banket & - & groot & - & groot \\
VBO verzorging & 1,11 & vrijwel geen & 1,08 & vrijwel geen \\
\hline
\end{tabular}

Bron: ROA

\subsubsection{Overige industrie}

\section{Actuele werkgelegenheid}

De overige industrie omvat de textiel-, de papier-, de hout- en bouwmaterialen- en de grafische industrie. Het aandeel van de overige industrie in de totale werkgelegenheid in Limburg verschilt aanzienlijk met het gemiddelde voor Nederland. In Limburg is 4,9 procent van alle werkenden werkzaam in de overige industrie tegenover een gemiddeld landelijk percentage van 3,4. De werkgelegenheid in de overige industrie is vooral hoog in ZuidLimburg.

Tabel 5.19

Aandeel overige industrie in totale werkgelegenheid in procenten, gemiddelde 1995-1996

Regio $\quad \%$

$\begin{array}{lc}\text { Limburg } & 4,9 \\ \text { Noord- en Midden-Limburg } & 4,6 \\ \text { Zuid-Limburg } & 5,2 \\ \text { Nederland } & 3,4\end{array}$

Bron: CBS/ROA

In Limburg werken er ten opzichte van het landelijk gemiddelde iets minder jongeren en ouderen in de overige industrie. Ten opzichte van het gemiddelde in Limburg als geheel is het percentage jongeren iets hoger en het percentage ouderen iets lager in de overige industrie. Het werkgelegenheidsaandeel van vrouwen ligt met 21 procent onder het landelijk gemiddelde van 25 procent. Ook het percentage deeltijdarbeid in de overige industrie ligt in Limburg onder het landelijk gemiddelde in deze sector. 
Tabel 5.20

Samenstelling van de werkgelegenheid in procenten, gemiddelde 1995-1996

\begin{tabular}{llllll}
\hline & $\begin{array}{l}\text { jongeren } \\
\%\end{array}$ & $\begin{array}{l}\text { ouderen } \\
\%\end{array}$ & $\begin{array}{l}\text { vrouwen } \\
\%\end{array}$ & $\begin{array}{l}\text { flexibel werk } \\
\%\end{array}$ & $\begin{array}{l}\text { deeltijdarbeid } \\
\%\end{array}$ \\
\hline Ov. Industrie in Limburg & 28 & 14 & 21 & - & 12 \\
Limburg totaal & 26 & 16 & 36 & 8 & 25 \\
& 29 & 16 & 25 & 8 & 16 \\
Ov. Industrie in Nederland & 29 & 15 & 37 & 8 & 27 \\
Nederland totaal & 29 & & & &
\end{tabular}

Bron: CBS/ROA

Tabel 5.21 laat zien dat het percentage VBO'ers in de overige industrie slechts 23 procent is, tegenover een landelijk percentage van 27 procent. Voor MBO'ers ligt dit percentage in Limburg op 40 procent tegenover 45 procent in Nederland als geheel. Daar staat tegenover dat er in de overige industrie in Limburg iets meer arbeidskrachten met slechts Basisonderwijs werkzaam zijn.

Tabel 5.21

Samenstelling van de werkgelegenheid naar opleidingsniveau in procenten, gemiddelde 1995-1996

\begin{tabular}{lrllll}
\hline & $\begin{array}{l}\text { Basis } \\
\%\end{array}$ & $\begin{array}{l}\text { VBO } \\
\%\end{array}$ & $\begin{array}{l}\text { MBO } \\
\%\end{array}$ & $\begin{array}{l}\text { HBO } \\
\%\end{array}$ & $\begin{array}{l}\text { WO } \\
\%\end{array}$ \\
\hline $\begin{array}{l}\text { Ov. Industrie in Limburg } \\
\text { Limburg totaal }\end{array}$ & 14 & 23 & 40 & - & - \\
& 9 & 24 & 44 & 17 & 5 \\
Ov. Industrie in Nederland & 12 & 27 & 45 & 11 & 3 \\
Nederland totaal & 8 & 22 & 44 & 18 & 7 \\
\hline
\end{tabular}

Bron: CBS/ROA

\section{Actuele discrepanties}

In tabel 5.22 wordt een indicatie gegeven van de rekruteringsproblemen die werkgevers in de overige industrie op de Limburgse arbeidsmarkt ondervinden. De vacaturegraad ligt met 11 vacatures per 1.000 werkenden voor de overige industrie iets onder het gemiddelde voor Limburg als geheel terwijl het percentage moeilijk vervulbare vacatures net iets hoger ligt. In de overige industrie zijn er per 100 werkzoekenden 74 vacatures. Daarmee neemt de overige industrie een gemiddelde positie in. 
Indicatoren voor de actuele discrepanties in de overige industrie, voorjaar 1997

\begin{tabular}{llll}
\hline & Limburg & $\begin{array}{l}\text { overige } \\
\text { industrie }\end{array}$ & typering \\
\hline Vacaturegraad (aantal vacatures per 1000 werkenden) & 19 & 11 & gemiddeld \\
$\begin{array}{l}\text { Percentage moeilijk vervulbare vacatures } \\
\text { Indicator arbeidsmarktkrapte }\end{array}$ & 25 & 26 & gemiddeld \\
& 0,77 & 0,74 & gemiddeld \\
\hline
\end{tabular}

Bron: Arbeidsvoorziening Limburg/CBS/ROA

Beroepsgroepen en opleidingstypen

Tabel 5.23 geeft de belangrijkste beroepsgroepen in de overige industrie weer. Met name voor grafisch productiepersoneel is de markt krap. Verder blijkt uit de tabel dat relatief veel vacatures voor bouwvakkers moeilijk vervulbaar zijn. Verder laat de tabel zien dat de vacaturegraad voor commercieel employés hoog is.

Tabel 5.23

Actuele arbeidsmarktindicatoren belangrijkste beroepsgroepen in de overige industrie, voorjaar 1997

\begin{tabular}{lrlll}
\hline Beroepsgroep & $\begin{array}{r}\text { aandeel } \\
\text { werkgelegenheid } \\
\%^{*}\end{array}$ & $\begin{array}{l}\text { vacature- } \\
\text { graad }\end{array}$ & $\begin{array}{l}\text { percentage moeilijk } \\
\text { vervulbare vacatures }\end{array}$ & $\begin{array}{l}\text { arbeidsmarkt- } \\
\text { krapte }\end{array}$ \\
\hline Grafische vakkrachten & 11 & - & - & - \\
Grafisch productiepersoneel & 8 &. & gemiddeld & 1,00 \\
Bouwvakkers & 7 & gemiddeld & hoog & 0,25 \\
Boekhouders en secretaresses & 6 & gemiddeld & gemiddeld & 0,36 \\
Commercieel employés & 6 & hoog & gemiddeld & 0,59 \\
\hline
\end{tabular}

${ }^{*}$ Gebaseerd op landelijke cijfers

Bron: CBS/Arbeidsvoorziening Limburg/ROA

In de overige industrie vormen de werkenden met Basisonderwijs als opleidingsachtergrond de grootste groep. Verder geldt dat de arbeidsmarktkrapte voor het opleidingstype $\mathrm{MBO} / \mathrm{LLW}$ handel de grootste rekruteringsproblemen veroorzaakt. Het percentage moeilijk vervulbare vacatures voor MBO/LLW grafische techniek is zeer hoog. 
Tabel 5.24

Actuele arbeidsmarktindicatoren belangrijkste opleidingstypen in de overige industrie, voorjaar 1997

\begin{tabular}{lrlll}
\hline Opleidingstype & $\begin{array}{r}\text { aandeel } \\
\text { werkgelegenheid } \\
\%^{2}\end{array}$ & $\begin{array}{l}\text { vacature- } \\
\text { graad }\end{array}$ & $\begin{array}{l}\text { percentage moeilijk } \\
\text { vervulbare vacatures }\end{array}$ & $\begin{array}{l}\text { arbeidsmarkt- } \\
\text { krapte }\end{array}$ \\
\hline Basisonderwijs & 12 & - & - & - \\
MBO/LLW grafische techniek & 11 & - & zeer hoog & 0,69 \\
MAVO & 8 & gemiddeld & gemiddeld & 0,16 \\
MBO/LLW handel & 6 & hoog & gemiddeld & 2,56 \\
HAVO/NWO & 5 & gemiddeld & gemiddeld & 0,14
\end{tabular}

${ }^{2}$ Gebaseerd op landelijke cijfers

Bron: CBS/Arbeidsvoorziening Limburg/ROA

\section{Toekomstige werkgelegenheidsontwikkeling}

Tabel 5.25 laat de werkgelegenheidsontwikkeling voor de overige industrie op korte en middellange termijn zien. De groei op middellange termijn voor de overige industrie in Limburg zal naar verwachting iets groter zijn dan de groei in de sector op landelijk niveau. Op korte termijn loopt de verwachte groei in de overige industrie aardig in de pas met de verwachte gemiddelde werkgelegenheidsgroei in Limburg als geheel. Verwacht wordt echter dat deze groei op middellange termijn echter enigszins achter zal blijven bij de provinciale werkgelegenheidsgroei.

Tabel 5.25

Uitbreidingsvraag in 1998 en tot 2002 in jaarlijkse groeipercentages

\begin{tabular}{lll}
\hline & $\begin{array}{l}1998 \\
\%\end{array}$ & $\begin{array}{l}1997-2002 \\
\%\end{array}$ \\
\hline Overige industrie in Limburg & 1,5 & 1,1 \\
Limburg totaal & 1,7 & 1,6 \\
Overige industrie in Nederland & - & 0,9 \\
Nederland totaal & - & 1,7 \\
\hline
\end{tabular}

Bron: TNO/Inro/CPB/ROA

Tabel 5.26 laat zien dat werkgevers in de overige industrie met name aanzienlijke inspanningen zullen moeten verrichten om nieuwe boekhouders en secretaresses aan te trekken. Voor deze beroepsgroep worden voor 1998 7,2 baanopeningen per 100 werkenden verwacht. Op de middellange termijn zal het aantal baanopeningen naar verwachting gemiddeld $6,3 \%$ per jaar bedragen. 


\section{Tabel 5.26}

Toekomstige werkgelegenheidsontwikkeling belangrijkste beroepsgroepen in de overige industrie (in procenten van het aantal werkenden)

\begin{tabular}{|c|c|c|c|c|}
\hline Beroepsgroep & $\begin{array}{l}\text { baanopeningen } \\
1998 \\
\%\end{array}$ & typering & $\begin{array}{l}\text { baanopeningen } \\
1997-2002 \\
\%\end{array}$ & typering \\
\hline Grafische vakkrachten & - & gemiddeld & - & gemiddeld \\
\hline Grafisch productiepersoneel & - & gemiddeld & - & laag \\
\hline Bouwvakkers & 4,9 & gemiddeld & 4,3 & gemiddeld \\
\hline Boekhouders en secretaresses & 7,2 & hoog & 6,3 & hoog \\
\hline Commercieel employés & 4,4 & gemiddeld & 3,7 & gemiddeld \\
\hline
\end{tabular}

Bron: ROA

Tabel 5.27 laat zien dat er op korte termijn grote knelpunten verwacht worden voor arbeidskrachten met MBO/LLW grafische techniek als opleidingsachtergrond. In de overige industrie zullen de knelpunten op middellange termijn naar verwachting verder toenemen. $\mathrm{Er}$ worden dan ook voor arbeidskrachten met het opleidingstype MBO/LLW handel grote knelpunten verwacht.

\section{Tabel 5.27}

Toekomstige knelpunten in de personeelsvoorziening voor de belangrijkste opleidingstypen in de overige industrie

\begin{tabular}{llllr}
\hline Opleidingstype & $\begin{array}{l}\text { ITKP } \\
1998\end{array}$ & typering & $\begin{array}{l}\text { ITKP } \\
2002\end{array}$ & typering \\
\hline Basisonderwijs & 1,11 & vrijwel geen & 1,33 & geen \\
MBO/LLW grafische techniek & - & groot & - & groot \\
MAVO & 1,09 & vrijwel geen & 1,00 & enige \\
MBO/LLW handel & 1,00 & enige & 0,93 & groot \\
HAVO/VWO & 1,11 & vrijwel geen & 1,09 & vrijwel geen \\
\hline
\end{tabular}

Bron: ROA

\subsubsection{Chemische industrie}

\section{Actuele werkgelegenheid}

In Limburg hebben meer dan 15.000 mensen een baan gevonden in de chemische, rubberen kunststofverwerkende industrie. Daarvan zijn 9.500 mensen werkzaam in de basischemie. De werkgelegenheid in de chemische industrie is in Zuid-Limburg relatief veel groter dan in Noord- en Midden-Limburg. Dit blijkt uit tabel 5.19. De chemische industrie in Zuid-Limburg herbergt 4,6 procent van alle werkenden in Zuid-Limburg tegenover 1,8 procent in Noord- en Midden-Limburg. Verder valt uit de tabel op te maken dat ten opzichte 
van het landelijk beeld een relatief groot deel van de werkenden in Limburg emplooi vindt in de chemische industrie.

Tabel 5.28

Aandeel chemische industrie in totale werkgelegenheid in procenten, gemiddelde 1995-1996

Regio $\quad \%$

Limburg

13,6

Noord- en Midden-Limburg

16,3

Zuid-Limburg

9,7

Nederland

8,3

Bron: CBS/ROA

Het percentage jongeren en ouderen dat werkzaam is in de chemische sector in Limburg wijkt niet significant af van het landelijk beeld, zoals tabel 5.20 laat zien.

Tabel 5.29

Samenstelling van de werkgelegenheid in de chemische industrie in procenten, gemiddelde 19951996

$\begin{array}{lllll}\text { jongeren } & \text { ouderen } & \text { vrouwen } & \text { flexibel werk } & \text { deeltijdarbeid } \\ \% & \% & \% & \% & \%\end{array}$

\begin{tabular}{llllll}
\hline Chemie in Limburg & 23 & 16 & - & - & - \\
Limburg totaal & 26 & 16 & 36 & 8 & 25 \\
& & & & & 10 \\
Chemie in Nederland & 24 & 18 & 18 & 8 & 27 \\
Nederland totaal & 29 & 15 & 37 & 8 & \\
\hline
\end{tabular}

Bron: CBS/ROA

Tabel 5.30 laat zien dat het opleidingsniveau van de werkzamen in de chemische sector in Limburg vergelijkbaar is met het niveau in de chemische sector op landelijk niveau. Alleen het percentage VBO'ers ligt met 16 procent aanzienlijk onder de 20 procent voor Nederland als geheel. Hiermee ligt het percentage VBO'ers tevens duidelijk onder het Limburgs gemiddelde. 
Tabel 5.30

Samenstelling van de werkgelegenheid naar opleidingsniveau in procenten, gemiddelde 1995-1996

\begin{tabular}{llllll}
\hline & $\begin{array}{l}\text { Basis } \\
\%\end{array}$ & $\begin{array}{l}\text { VBO } \\
\%\end{array}$ & $\begin{array}{l}\text { MBO } \\
\%\end{array}$ & $\begin{array}{l}\text { HBO } \\
\%\end{array}$ & $\begin{array}{l}\text { WO } \\
\%\end{array}$ \\
\hline $\begin{array}{l}\text { Chemie in Limburg } \\
\text { Limburg totaal }\end{array}$ & - & 16 & 45 & 16 & - \\
Chemie in Nederland & 9 & 24 & 44 & 17 & 5 \\
Nederland totaal & 9 & 20 & 46 & 16 & 7 \\
\hline
\end{tabular}

Bron: CBS/ROA

Actuele discrepanties

In tabel 5.31 wordt een indicatie gegeven van de rekruteringsproblemen die werkgevers in de chemische sector op de Limburgse arbeidsmarkt ondervinden. De vacaturegraad is in de chemie met 8 vacatures per 1.000 werkenden relatief laag. Ook het percentage moeilijk vervulbare vacatures is met 18 procent laag. Daar staat tegenover dat deze sector wel te kampen heeft met een krappe arbeidsmarkt. Uit de tabel blijkt dat er per 100 werkzoekenden 90 vacatures zijn. Over het algemeen kan dus gesteld worden dat hoewel er relatief weinig werkzoekenden beschikbaar zijn per vacature, de chemische sector relatief weinig rekruteringsproblemen kent. 
Tabel 5.31

Indicatoren voor de actuele discrepanties in de chemische industrie, voorjaar 1997

\begin{tabular}{|c|c|c|c|}
\hline & Limburg & chemie & typering \\
\hline Vacaturegraad (aantal vacatures per 1000 werkenden) & 19 & 8 & laag \\
\hline Percentage moeilijk vervulbare vacatures & 25 & 18 & laag \\
\hline Indicator arbeidsmarktkrapte & 0,77 & 0,90 & zeer hoog \\
\hline
\end{tabular}

Bron: Arbeidsvoorziening Limburg/CBS/ROA

\section{Beroepsgroepen en opleidingstypen}

Tabel 5.32 geeft een overzicht van de vijf grootste beroepsgroepen in de werkgelegenheid in de chemische, rubber- en kunststofverwerkende industrie. Voor elk van de beroepsgroepen wordt aangegeven hoe de huidige situatie op de Limburgse arbeidsmarkt is. Er zijn relatief weinig vacatures voor de functie van monteur. Een groot deel van deze vacatures blijkt echter moeilijk te vervullen. Dit komt mede door de krapte op de arbeidsmarkt. Per werkzoekende staat er 1,04 vacature open. Ondanks het feit dat er voor productiemedewerkers bijna vijf werkzoekenden per vacature beschikbaar zijn, blijkt een groot deel van deze vacatures toch moeilijk te vervullen.

Tabel 5.32

Actuele arbeidsmarktindicatoren belangrijkste beroepsgroepen in de chemische industrie, voorjaar 1997

\begin{tabular}{lclll}
$\begin{array}{l}\text { Beroepsgroep } \\
\text { werkgelegenheid } \\
\%^{*}\end{array}$ & $\begin{array}{l}\text { aandeel } \\
\text { graad }\end{array}$ & $\begin{array}{l}\text { percentage moeilijk } \\
\text { vervulbare vacatures }\end{array}$ & $\begin{array}{l}\text { arbeidsmarkt- } \\
\text { krapte }\end{array}$ \\
\hline & 14 & - & - & - \\
Mechanisch operators & 14 & gemiddeld & gemiddeld & 0,59 \\
Procesoperators & 6 & gemiddeld & gemiddeld & 0,36 \\
Boekhouders en secretaresses & 5 & laag & hoog & 1,04 \\
Monteurs & 5 & hoog & hoog & 0,22 \\
Productiemedewerkers & & & & \\
\hline
\end{tabular}

\footnotetext{
${ }^{*}$ Gebaseerd op landelijke cijfers

Bron: CBS/Arbeidsvoorziening Limburg/ROA
}

Tabel 5.33 geeft een overzicht van de grootste opleidingstypen in de werkgelegenheid in de chemische industrie. Uit de tabel blijkt dat er momenteel voor deze opleidingstypen weinig knelpunten op de arbeidsmarkt ondervonden worden. De vacaturegraad is laag. Bovendien wordt voor de vacatures meestal binnen afzienbare tijd een geschikte kandidaat gevonden. Opvallend is het relatief lage aantal direct inzetbare werkzoekenden dat beschikbaar is voor vacatures waarvoor de opleidingsachtergrond MBO/LLW procestechniek gevraagd wordt. 
Tabel 5.33

Actuele arbeidsmarktindicatoren belangrijkste opleidingstypen in de chemische industrie, voorjaar 1997

\begin{tabular}{lllll}
\hline Opleidingstype & $\begin{array}{r}\text { aandeel } \\
\text { werkgelegenheid } \\
\%^{2}\end{array}$ & $\begin{array}{l}\text { vacature- } \\
\text { graad }\end{array}$ & $\begin{array}{l}\text { percentage moeilijk } \\
\text { vervulbare vacatures }\end{array}$ & $\begin{array}{l}\text { arbeidsmarkt- } \\
\text { krapte }\end{array}$ \\
\hline Basisonderwijs & 9 & - & - & - \\
MBO/LLW procestechniek & 8 & laag & zeer laag & 2,40 \\
MAVO & 7 & gemiddeld & gemiddeld & 0,16 \\
MBO/LLW administratie & 5 & gemiddeld & gemiddeld & 0,29 \\
HBO laboratorium & 5 & - & - & - \\
\hline
\end{tabular}

${ }^{2}$ Gebaseerd op landelijke cijfers

Bron: CBS/Arbeidsvoorziening Limburg/ROA

\section{Toekomstige werkgelegenheidsontwikkeling}

De verwachte werkgelegenheidsontwikkeling voor de chemische, rubber- en kunststofverwerkende industrie in Limburg past volledig in het beeld voor de landelijke werkgelegenheidsontwikkeling en de werkgelegenheidsontwikkeling in Limburg. Tot 2002 wordt een jaarlijkse werkgelegenheidsgroei van 1,7 procent verwacht.

Tabel 5.34

Uitbreidingsvraag in 1998 en tot 2002 in jaarlijkse groeipercentages

\begin{tabular}{lll}
\hline & $\begin{array}{l}1998 \\
\%\end{array}$ & $\begin{array}{l}1997-2002 \\
\%\end{array}$ \\
\hline Chemie in Limburg & 1,7 & 1,7 \\
Limburg totaal & 1,7 & 1,6 \\
Chemie in Nederland & - & 1,7 \\
Nederland totaal & - & 1,7 \\
\hline
\end{tabular}

Bron: TNO/Inro/CPB/ROA

Tabel 5.35 schetst het verwachte percentage baanopeningen voor de grootste beroepsgroepen in de chemische industrie. Voor de beroepsgroep boekhouders en secretaresses worden in 1998 7,2 baanopeningen per 100 werknemers verwacht. Tot 2002 wordt verwacht dat dit aantal iets lager ligt, namelijk 6,3 per jaar; het percentage blijft echter relatief hoog. Voor de middellange termijn worden er in Limburg relatief weinig baanopeningen voor de beroepsgroep mechanische operators verwacht. Voor 1998 worden er relatief weinig baanopeningen verwacht voor productiemedewerkers. 
Tabel 5.35

Toekomstige werkgelegenheidsontwikkeling belangrijkste beroepsgroepen in de chemische industrie (in procenten van het aantal werkenden)

\begin{tabular}{lllll}
\hline Beroepsgroep & $\begin{array}{l}\text { baanopeningen } \\
1998 \\
\%\end{array}$ & typering & $\begin{array}{l}\text { baanopeningen } \\
1997-2002 \\
\%\end{array}$ & typering \\
& & & & \\
& 3,7 & gemiddeld & 3,0 & laag \\
Mechanisch operators & 3,7 & gemiddeld & 3,5 & gemiddeld \\
$\begin{array}{l}\text { Procesoperators } \\
\text { Boekhouders en secretaresses } \\
\text { Monteurs }\end{array}$ & 3,2 & hoog & 6,3 & hoog \\
Productiemedewerkers & 2,3 & laag & 3,6 & gemiddeld \\
& laag & 3,9 & gemiddeld \\
\hline
\end{tabular}

Bron: ROA

De chemische industrie wordt in de nabije toekomst naar verwachting geconfronteerd met toenemende knelpunten in de personeelsvoorziening. Met name bij het aantrekken van personeel met de opleidingsachtergrond MBO/LLW procestechniek is de toenemende krapte goed zichtbaar. Ook voor arbeidskrachten met het opleidingstype MBO/LLW administratie wordt in de toekomst een krappe arbeidsmarkt verwacht.

Tabel 5.36

Toekomstige knelpunten in de personeelsvoorziening voor de belangrijkste opleidingstypen in de chemische industrie

\begin{tabular}{lllll} 
Opleidingstype & $\begin{array}{l}\text { ITKP } \\
1998\end{array}$ & typering & $\begin{array}{l}\text { ITKP } \\
2002\end{array}$ & typering \\
\hline Basisonderwijs & 1,11 & vrijwel geen & 1,33 & geen \\
MBO/LLW procestechniek & 0,94 & groot & 0,74 & zeer groot \\
MAVO & 1,09 & vrijwel geen & 1,00 & enige \\
MBO/LLW administratie & 1,00 & enige & 0,88 & groot \\
HBO laboratorium & - & - & - & - \\
\hline
\end{tabular}

Bron: ROA

\subsubsection{Metaalindustrie}

\section{Actuele werkgelegenheid}

In de metaalindustrie zijn in Limburg 59.000 mensen werkzaam: 27.000 in de basismetaal, 25.000 in de machine- en elektrotechnische industrie en 7.500 in de transportmiddelenindustrie. Het belang van de metaalindustrie is in Noord- en MiddenLimburg groter dan in Zuid-Limburg. De werkgelegenheid in Noord- en Midden-Limburg vormt 16,3 procent van de totale werkgelegenheid in die regio. Voor Zuid-Limburg is dit percentage slechts 9,7. De werkgelegenheid in de metaalindustrie in Limburg is relatief groot 
ten opzichte van de werkgelegenheid in de metaalindustrie op landelijk niveau.

Tabel 5.37

Aandeel metaalindustrie in totale werkgelegenheid in procenten, gemiddelde 1995-1996

Regio \%

Limburg

Noord- en Midden-Limburg

Zuid-Limburg

Nederland
$\%$

13,6

16,3

9,7

8,3

Bron: CBS/ROA

De percentages jongeren, ouderen en vrouwen werkzaam in de metaalindustrie in Limburg zijn vergelijkbaar met de percentages in de metaalindustrie op landelijk niveau. Kenmerkend voor de industrie in het algemeen is het lage percentage vrouwen. Het percentage flexibel werk in de metaalindustrie ligt iets hoger dan het landelijk niveau terwijl het percentage deeltijdarbeid juist iets lager ligt. Verder valt op dat er erg weinig deeltijders werkzaam zijn in de metaalindustrie ten opzichte van de andere bedrijfssectoren.

Tabel 5.38

Samenstelling van de werkgelegenheid in de metaalindustrie in procenten, gemiddelde 1995-1996

\begin{tabular}{llllll}
\hline & $\begin{array}{l}\text { jongeren } \\
\%\end{array}$ & $\begin{array}{l}\text { ouderen } \\
\%\end{array}$ & $\begin{array}{l}\text { vrouwen } \\
\%\end{array}$ & $\begin{array}{l}\text { flexibel werk } \\
\%\end{array}$ & $\begin{array}{l}\text { deeltijdarbeid } \\
\%\end{array}$ \\
\hline Metaal in Limburg & 27 & 15 & 14 & 9 & 8 \\
Limburg totaal & 26 & 16 & 36 & 8 & 25 \\
Metaal in Nederland & 27 & 16 & 14 & 7 & 10 \\
Nederland totaal & 29 & 15 & 37 & 8 & 27 \\
\hline
\end{tabular}

Bron: CBS/ROA

Ook het beeld van het opleidingsniveau van werknemers in de metaalindustrie in Limburg sluit aan bij het landelijk beeld in de metaalindustrie. Ten opzichte van andere bedrijfssectoren in Limburg ligt het gemiddelde opleidingsniveau beduidend lager. Er zijn aanzienlijk meer VBO'ers en minder HBO'ers actief in de metaalindustrie in vergelijking met Limburg als geheel. 
Tabel 5.39

Samenstelling van de werkgelegenheid naar opleidingsniveau in procenten, gemiddelde 1995-1996

\begin{tabular}{lccccc}
\hline & $\begin{array}{l}\text { Basis } \\
\%\end{array}$ & $\begin{array}{l}\text { VBO } \\
\%\end{array}$ & $\begin{array}{l}\text { MBO } \\
\%\end{array}$ & $\begin{array}{l}\text { HBO } \\
\%\end{array}$ & $\begin{array}{l}\text { WO } \\
\%\end{array}$ \\
\hline Metaal in Limburg & 12 & 33 & 39 & 11 & - \\
Limburg totaal & 9 & 24 & 44 & 17 & 5 \\
Metaal in Nederland & 13 & 29 & 43 & 11 & 3 \\
Nederland totaal & 8 & 22 & 44 & 18 & 7 \\
\hline
\end{tabular}

Bron: $\mathrm{CBS} / \mathrm{ROA}$

\section{Actuele discrepanties}

De metaalindustrie in Limburg heeft te kampen met een zeer hoog percentage moeilijk vervulbare vacatures. Dit blijkt uit tabel 5.40. Dit komt veelal door een krappe arbeidsmarkt op de arbeidsmarktsegmenten waarin de metaalindustrie rekruteert. Per 100 werkzoekenden staan er 82 vacatures open. De vacaturegraad in de metaalindustrie is laag.

Tabel 5.40

Indicatoren voor de actuele discrepanties in de metaalindustrie, voorjaar 1997

\begin{tabular}{llll}
\hline & Limburg & metaal & typering \\
\hline & & & \\
Vacaturegraad (aantal vacatures per 1000 werkenden) & 19 & 13 & gemiddeld \\
Percentage moeilijk vervulbare vacatures & 25 & 39 & zeer hoog \\
Indicator arbeidsmarktkrapte & 0,77 & 0,82 & hoog \\
\hline
\end{tabular}

Bron: Arbeidsvoorziening Limburg/CBS/ROA

\section{Beroepsgroepen en opleidingstypen}

Tabel 5.41 spitst het algemene beeld nader toe. De tabel beschrijft de vijf grootste beroepsgroepen in de metaalindustrie. Vooral voor metaalarbeiders blijkt het moeilijk een geschikte kandidaat voor de vacature te vinden, waardoor relatief erg veel vacatures gedurende langere tijd onvervuld blijven. Ondanks de lage vacaturegraad voor monteurs blijkt het ook voor deze functies moeilijk te zijn nieuwe arbeidskrachten binnen afzienbare tijd te vinden. Eén van de oorzaken is een relatief laag aanbod van direct inzetbare werkzoekenden die deze functie willen vervullen. Voor iedere werkzoekende die deze functie ambieert, staan er 1,04 vacatures open. 
Tabel 5.41

Actuele arbeidsmarktindicatoren belangrijkste beroepsgroepen in de metaalindustrie, voorjaar 1997

\begin{tabular}{lrlll}
\hline Beroepsgroep & $\begin{array}{r}\text { aandeel } \\
\text { werkgelegenheid } \\
\%^{*}\end{array}$ & $\begin{array}{l}\text { vacature- } \\
\text { graad }\end{array}$ & $\begin{array}{l}\text { percentage moeilijk } \\
\text { vervulbare vacatures }\end{array}$ & $\begin{array}{l}\text { arbeidsmarkt- } \\
\text { krapte }\end{array}$ \\
\hline Metaalarbeiders & 13 & gemiddeld & erg hoog & 0,42 \\
Monteurs & 10 & laag & hoog & 1,04 \\
Bankwerkers en lassers & 8 & gemiddeld & gemiddeld & 0,43 \\
Boekhouders en secretaresses & 5 & gemiddeld & gemiddeld & 0,36 \\
Productiemedewerkers & 5 & hoog & hoog & 0,22 \\
\hline
\end{tabular}

* Gebaseerd op landelijke cijfers

Bron: CBS/Arbeidsvoorziening Limburg/ROA

Tabel 5.42 beschrijft de vijf grootste opleidingstypen in de werkgelegenheid in de metaalindustrie. Deze tabel bevestigt het hierboven geschetste beeld dat er relatief veel laaggeschoold personeel werkzaam is in de metaalindustrie. Op dit moment blijkt het erg lastig te zijn om arbeidskrachten met de opleidingsachtergrond MBO/LLW mechanische techniek en werktuigbouwkunde aan te trekken. De vacaturegraad is hoog en de arbeidsmarktkrapte is aanzienlijk. Daardoor blijven relatief veel vacatures langere tijd onvervuld. Voor de overige genoemde opleidingstypen blijken de problemen relatief gering.

Tabel 5.42

Actuele arbeidsmarktindicatoren belangrijkste opleidingstypen in de metaalindustrie, voorjaar 1997

\begin{tabular}{lrlll}
\hline Opleidingstype & $\begin{array}{r}\text { aandeel } \\
\text { werkgelegenheid } \\
\%^{*}\end{array}$ & $\begin{array}{l}\text { vacature- } \\
\text { graad }\end{array}$ & $\begin{array}{l}\text { percentage moeilijk } \\
\text { vervulbare vacatures }\end{array}$ & $\begin{array}{l}\text { arbeidsmarkt- } \\
\text { krapte }\end{array}$ \\
\hline Basisonderwijs & 13 & - & - & - \\
MBO/LLW mechanische techn. & 12 & zeer hoog & hoog & 0,84 \\
VBO mechanische techniek & 8 & laag & zeer laag & 0,11 \\
MAVO & 6 & gemiddeld & gemiddeld & 0,16 \\
MBO/LLW elektrotechniek & 5 & laag & zeer laag & 0,07
\end{tabular}

* Gebaseerd op landelijke cijfers

Bron: CBS/Arbeidsvoorziening Limburg/ROA

\section{Toekomstige werkgelegenheidsontwikkeling}

Tabel 5.43 laat zien dat de werkgelegenheid in de metaalindustrie zich de komende jaren naar verwachting gunstig zal ontwikkelen. Zowel op de korte termijn (1998) als op de middellange termijn (tot 2002) wordt in de Limburgse metaalindustrie een werkgelegenheidtoename verwacht die aanzienlijk groter zal zijn dan de gemiddelde werkgelegenheidsgroei in de provincie. Een vergelijking met het landelijke beeld laat zien dat 
de Limburgse metaalindustrie naar verwachting relatief sterk zal groeien vergeleken met de metaalindustrie in de rest van het land.

Tabel 5.43

Uitbreidingsvraag in 1998 en tot 2002 in jaarlijkse groeipercentages

\begin{tabular}{lll}
\hline & $\begin{array}{l}1998 \\
\%\end{array}$ & $\begin{array}{l}1997-2002 \\
\%\end{array}$ \\
\hline Metaal in Limburg & 3,3 & 2,8 \\
Limburg totaal & 1,7 & 1,6 \\
Metaal in Nederland & - & 1,8 \\
Nederland totaal & - & 1,7 \\
\hline
\end{tabular}

Bron: TNO/Inro/CPB/ROA

In tabel 5.44 staan wederom de vijf grootste beroepsgroepen in de metaalindustrie weergegeven. Voor elk van die beroepsgroepen is aangegeven hoeveel baanopeningen per 100 werknemers verwacht worden op de korte en middellange termijn. Dit percentage geeft een indicatie van de rekruteringsinspanningen die werkgevers zullen dienen te leveren om de werkgelegenheidsgroei en de vervangingsbehoefte op te vangen. Dit percentage ligt op de korte termijn voor metaalarbeiders met 5,1 procent naar verwachting hoger dan op de middellange termijn. Voor 1998 wordt een relatief hoge vraag naar boekhouders en secretaresses verwacht. Deze vraag zal naar verwachting op de middellange termijn iets lager liggen, maar blijft naar verwachting nog steeds hoog ten opzichte van andere beroepsgroepen.

\section{Tabel 5.44}

Toekomstige werkgelegenheidsontwikkeling belangrijkste beroepsgroepen in de metaalindustrie (in procenten van het aantal werkenden)

\begin{tabular}{lllll}
\hline Beroepsgroep & $\begin{array}{l}\text { baanopeningen } \\
1998 \\
\%\end{array}$ & typering & $\begin{array}{l}\text { baanopeningen } \\
1997-2002 \\
\%\end{array}$ & typering \\
& & & & \\
\hline Metaalarbeiders & 5,1 & gemiddeld & 4,0 & gemiddeld \\
Monteurs & 3,3 & laag & 3,6 & gemiddeld \\
Bankwerkers en lassers & 4,9 & gemiddeld & 3,9 & gemiddeld \\
$\begin{array}{l}\text { Boekhouders en secretaresses } \\
\text { Productiemedewerkers }\end{array}$ & 2,2 & hoog & 6,3 & goog \\
& 2,9 & laag & 3,9 & \\
\hline
\end{tabular}

Bron: ROA

In tabel 5.45 wordt voor de vijf belangrijkste opleidingstypen in de werkgelegenheid in de metaalindustrie aangegeven of er knelpunten verwacht worden bij het aantrekken van arbeidskrachten met die opleidingsachtergrond. Voor 1998 worden er alleen grote 
knelpunten in de personeelsvoorziening verwacht bij het aantrekken van arbeidskrachten met de opleidingsachtergrond MBO/LLW elektrotechniek. Voor de middellange termijn wordt verwacht dat de knelpunten groter zullen worden. Ook wordt er op de middellange termijn een tekort verwacht aan arbeidskrachten met de opleidingsachtergrond MBO/LLW mechanische techniek en werktuigbouwkunde. Verder zouden er enige knelpunten kunnen optreden bij het aantrekken van MAVO'ers.

Tabel 5.45

Toekomstige knelpunten in de personeelsvoorziening voor de belangrijkste opleidingstypen in de metaalindustrie

\begin{tabular}{lllll}
\hline Opleidingstype & $\begin{array}{l}\text { ITKP } \\
1998\end{array}$ & typering & $\begin{array}{l}\text { ITKP } \\
2002\end{array}$ & typering \\
& & & & \\
\hline Basisonderwijs & 1,11 & vrijwel geen & 1,33 & geen \\
MBO/LLW mechanische techniek & 1,08 & vrijwel geen & 0,97 & groot \\
VBO mechanische techniek & 1,02 & enige & 1,05 & vrijwel geen \\
MAVO & 1,09 & vrijwel geen & 1,00 & enige \\
MBO/LLW elektrotechniek & 0,99 & groot & 0,86 & groot \\
\hline
\end{tabular}

Bron: ROA

\subsubsection{Een nadere typering van de moeilijk vervulbare vacatures in de industrie}

In de telefonische enquête en de diepte-interviews wordt door werkgevers in de industrie aangegeven dat met name in de volgende beroepsgroepen vacatures moeilijk vervulbaar zijn ${ }^{67}$ :

- productiemedewerkers;

- operators;

- procesoperators;

- documentalist;

- besturingstechnoloog;

- monteurs in buitendienst;

- grafische vakkrachten;

- hogere R\&D elektro-functies;

- hogere informatici management stuur-informatie;

- secretaresse.

Voor een aantal van deze beroepsgroepen kan aan de hand van de enquête en de interviews een dieper inzicht in de aansluitingsproblematiek verkregen worden.

67. Zie Van Camp, H., 1997a, op.cit. en Van Camp, H., 1997b, op.cit. 


\section{Productiemedewerkers}

Functie-eisen:

opleiding:

ervaring:

leeftijd:

pers. kenmerk:

essentiële eis:

oorzaken:

uitwisselbaarheid:

\section{Operators}

Functie-eisen:

opleiding:

ervaring:

leeftijd:

pers. kenmerk:

essentiële eis:

oorzaken:

oplossingsrichtingen:

uitwisselbaarheid:

\section{Procesoperators}

Functie-eisen:

opleiding:

ervaring:

leeftijd:

pers. kenmerk:

essentiële eis:

oorzaken:
LTS-C, mavo met exacte vakken,

Geen opleidingseisen, maar wel bepaalde persoonskenmerken geen

geen

flexibiliteit in werktijden, nl. ploegendienst, hygiëne, collegialiteit, beheersing van de Nederlandse taal

houding en ploegendienst

gering aanbod, mede door concentratie van dit werk in een beperkte regio (van onder andere Westelijke Mijnstreek)

Aanbod onvoldoende gekwalificeerd inzake houding, discipline

al in groep 8 van de basisschool de leerlingen masseren voor technisch werk, voor werken in de industrie poolvorming met bedrijven die gelijksoortig personeel nodig hebben

alleen met andere bedrijven

LTS-C al of niet met specifieke richting (E of W), MAS, MAVO met exacte vakken

geen

geen

werken in ploegendiensten, wil tot opleiding volgen, collegialiteit

technische feeling

gering aanbod, dat bovendien onvoldoende gemotiveerd is voor werken in ploegendienst

opleidingsrichting verschuiven van $E$ naar $W$, training on the job middels VAPRO-LCB

opleidingsrichting: $\mathrm{E}$ vervangen door $\mathrm{W}$ en omgekeerd

MTS-P, VAPRO-B

soms wel en soms niet

er wordt wel eens een leeftijd gesteld van ongeveer 18 jaar

werken in ploegendiensten, collegialiteit, stressbestendig, verantwoordelijkheidsgevoel

MTS

onvoldoende aanbod door lage uitstroom uit onderwijs, soort werk onbekend en dat maakt onbemind 
oplossingsrichtingen: uitwisselbaarheid:

\section{Documentalist}

Functie-eisen:

opleiding:

ervaring:

leeftijd:

pers. kenmerk:

essentiële eis:

oorzaken:

oplossingsrichtingen:

uitwisselbaarheid:
MTS met talen en kunnen schrijven

kennis van bedrijf en de gemaakte producten

geen

flexibiliteit

technische tekeningen kunnen lezen

geen aanbod, want combinatie techniek en talenkennis en schrijven is geen gebruikelijke combinatie

zelf inwerken en opleiden op die facetten waar gebreken zijn

geen

\section{Besturingstechnoloog \\ Functie-eisen: \\ opleiding: \\ MTS-E of meet- en regeltechniek \\ ervaring: \\ meestal niet en soms wel \\ leeftijd: \\ soms maximaal 35 jaar \\ pers. kenmerk: \\ opleidingen willen volgen \\ essentiële eis: \\ MTS \\ oorzaken: \\ dalend aanbod, zowel kwantitatief als kwalitatief \\ oplossingsrichtingen: \\ bedrijfsintern opleiden mede met behulp van externe cursussen (leveranciers, VAPRO, Som), interne doorstroom bevorderen, poolvorming met andere bedrijven, samenwerking met ROC \\ uitwisselbaarheid: MTS-richtingen elektro en meet- en regeltechniek, eventueel ook nog werktuigbouw}

\section{Monteurs in buitendienst}

Functie-eisen:

opleiding:

ervaring:

leeftijd:

pers. kenmerk:

essentiële eis:

oorzaken:

oplossingsrichtingen: minimaal MTS, in toekomst HTS, richtingen E of W en/of PLC ja, algemeen en bedrijfsspecifiek (minimaal 2 jaar bedrijfservaring) minimaal 25 jaar

klantgerichte instelling, initiatief nemen, probleemoplossend denken en ter plekke kunnen improviseren

MBO-plus - HBO technisch niveau met klantgerichte instelling

geen aanbod

intern doorstromen of intern opleiden (duurt dan ongeveer 2 jaar) 
uitwisselbaarheid: geen

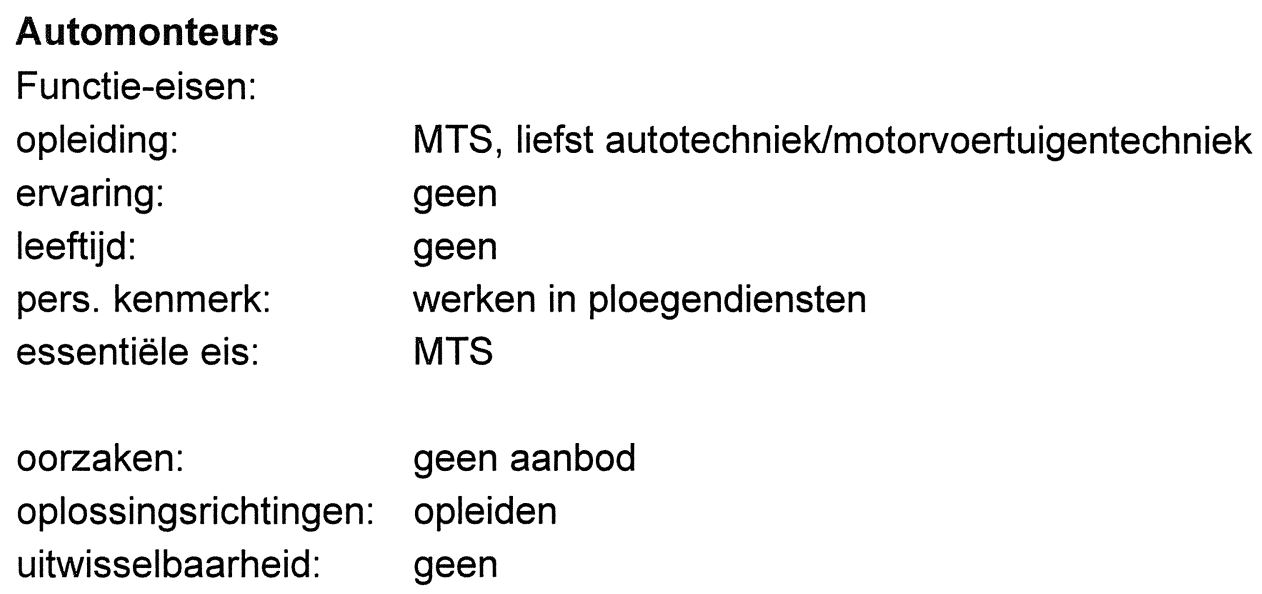

\section{Grafische vakkrachten}

Functie-eisen:

opleiding:

ervaring:

VBO, MAVO, grafisch lyceum Eindhoven, CBB Heerlen

leeftijd: geen

20-25 jaar als er nog een vakgerichte opleiding gevolgd moet worden (dus bij VBO, MAVO), daarna geldt een leeftijdsgrens van ongeveer maximaal 35 jaar

pers. kenmerk:

geen

essentiële eis:

wil tot grafische opleiding

oorzaken:

geen aanbod

oplossingsrichtingen:

wegkopen bij andere grafische bedrijven (grotere bedrijven werven onder de kleinere bedrijven)

uitwisselbaarheid:

geen

\section{Hogere R\&D Elektro-functies}

Functie-eisen:

opleiding:

ervaring:

leeftijd:

pers. kenmerk:

essentiële eis:

oorzaken:

oplossingsrichtingen:

uitwisselbaarheid:
HTS/WO-elektro

ja

geen

zelfstandigheid en collegialiteit

HTS

op landelijk niveau een relatief grote vraag tegenover een gering aanbod; Limburg in het nadeel vanwege geringe werkgelegenheidsmogelijkheden voor partner

eerst intern werven, daarna met behulp van wervings- en selectiebureau ook extern werven, interne doorstroming afhankelijk van de groep R\&D met personele samenstelling (kennis en ervaring) 
Hogere informatici management stuur-informatie

Functie-eisen:

opleiding:

HTS/WO-informatica met managementopleiding

ervaring:

op terrein van managementvraagstukken

leeftijd:

geen

pers. kenmerk:

geen

essentiële eis:

HBO-niveau

oorzaken:

geen aanbod

oplossingsrichtingen:

uitwisselbaarheid:

zelf bedrijfsintern opleiden

geen

\section{Secretaresse}

Functie-eisen:

opleiding:

MEAO, Schoevers

ervaring:

niet-direct noodzakelijk

leeftijd:

geen

pers. kenmerk:

zorgvuldigheid, stressbestendig, initiatiefnemend, bedrijfsintern snel de weg leren kennen (wie-wat waar-waarom)

essentiële eis:

$\mathrm{MBO}$

oorzaken:

onvoldoende aanbod voor grote vraag

oplossingsrichtingen: opleiden

uitwisselbaarheid: geen 


\subsection{Inleiding}

Bij- en omscholing van werkzoekenden kan een effectief middel zijn om discrepanties tussen vraag en aanbod op de arbeidsmarkt te verminderen. Door middel van bijscholing kunnen aansluitingsproblemen tussen de vaardigheden waarover de werkzoekenden in een bepaald arbeidsmarktsegment beschikken en de in dat segment gevraagde vaardigheden verminderd worden. Met andere woorden: bijscholing kan een effectief middel zijn om kwalitatieve aansluitingsproblemen in een bepaald arbeidsmarktsegment het hoofd te bieden. Door middel van omscholing kunnen knelpunten op de arbeidsmarkt, die hun oorsprong vinden in het feit dat er in een specifiek arbeidsmarktsegment geen werkzoekenden beschikbaar zijn om aan de vraag te voldoen, verminderd worden. Omscholing van werkzoekenden waarvoor er sprake is van een overschot, kan dus een effectief middel zijn om kwantitatieve aansluitingsproblemen op andere arbeidsmarktsegmenten te verminderen.

Het belang van scholing wordt onderstreept door de intermediairs op de arbeidsmarkt ${ }^{68}$. Zij geven aan dat de arbeidsmarktproblematiek grotendeels een scholings- en trainingsvraagstuk is. $\mathrm{Er}$ is in principe voldoende aanbod beschikbaar. Vaak sluiten de kwalificaties echter onvoldoende aan bij de eisen die door de vraagzijde van de arbeidsmarkt gesteld worden. Het gaat hierbij niet alleen om vakinhoudelijke vaardigheden, maar ook om werkhouding, communicatieve vaardigheden, een klantgerichte instelling, e.d. Hierbij wordt overigens ook de rol die het bedrijfsleven zelf kan spelen in het bij- en omscholen van de beroepsbevolking benadrukt.

Bij- en omscholing nemen vanzelfsprekend enige tijd in beslag. Scholingsprogramma's zullen daarom het meest effectief zijn wanneer ze kunnen anticiperen op te verwachten toekomstige knelpunten. Wanneer het scholingsbeleid gebaseerd wordt op de huidige knelpunten op de arbeidsmarkt bestaat het gevaar dat bij- en omgeschoolde werkzoekenden na afloop van hun scholingsperiode geconfronteerd worden met een gewijzigde arbeidsmarktsituatie waarin geen sprake meer is van een tekort aan arbeidskrachten met de kennis en vaardigheden die zij zojuist hebben verworven. Scholingsprogramma's zijn over het algemeen gericht op de korte termijn. Arbeidsvoorziening gaat er bijvoorbeeld van uit dat voor de werkzoekenden in fase 2 een scholingstraject van korter dan een jaar voldoende kan zijn om een volwaardige plaats op de arbeidsmarkt te verwerven. Het ligt daarom erg voor de hand om arbeidsmarktprognoses voor de korte termijn als richtlijn te nemen voor het te voeren scholingsbeleid ${ }^{69}$.

68. Van Camp, H., 1997d, op. cit.

69. Opgemerkt dient te worden dat in dit hoofdstuk het marktconforme scholingsbeleid, gericht op de discrepanties tussen vraag en aanbod op de arbeidsmarkt, centraal staat. 
In dit hoofdstuk wordt een raamwerk gepresenteerd dat richting kan geven aan het scholingsbeleid van werkzoekenden. Hierbij wordt uitgegaan van de korte-termijnprognoses zoals die gepresenteerd zijn in hoofdstuk 3 van dit rapport. Drie indicatoren staan daarbij centraal. In de eerste plaats de Indicator Toekomstige Knelpunten Personeelsvoorziening (ITKP) naar opleidingstype. Deze indicator geeft de verhouding weer tussen enerzijds de verwachte baanopeningen in 1998 en anderzijds het direct inzetbare arbeidsaanbod. Dit arbeidsaanbod heeft betrekking op de schoolverlaters en de direct bemiddelbare nietwerkende werkzoekenden, zoals die door Arbeidsvoorziening Limburg zijn ingedeeld in fase $1^{70}$. Vooral wanneer het verwachte aantal baanopeningen het aanbod overtreft kunnen marktconforme bij- en omscholingsprogramma's een effectief middel vormen om op deze verwachte knelpunten te anticiperen.

De tweede indicator is een maatstaf voor de scholingsbehoefte. Deze indicator geeft het verschil weer tussen het totaal aantal openstaande vacatures en de verwachte baanopeningen en het direct inzetbare arbeidsaanbod. Met andere woorden: de scholingsbehoefte is gelijk aan de vraag die niet door het direct inzetbare aanbod kan worden vervuld.

De derde indicator heeft betrekking op het bijscholingspotentieel in verhouding tot de omvang van de scholingsbehoefte. Deze indicator geeft de verhouding weer tussen enerzijds het aantal openstaande vacatures en baanopeningen dat niet door het direct inzetbare aanbod kan worden ingevuld en anderzijds het aantal werkzoekenden met een wat grotere afstand tot de arbeidsmarkt, dat wil zeggen: de werkzoekenden zoals die door Arbeidsvoorziening Limburg zijn ingedeeld in fase 2 of $3^{71}$.

Deze drie indicatoren bieden de mogelijkheid drie verschillende situaties te onderscheiden die elk een andere scholingsaanpak vragen ${ }^{72}$ :

\section{Een ruime arbeidsmarkt.}

Op de vraag of scholingsprogramma's om andere redenen - bijvoorbeeld in het licht van het doelgroepenbeleid - wenselijk of effectief zijn wordt in dit rapport niet ingegaan.

70. Zie voor meer bijzonderheden hoofdstuk 3 van dit rapport.

71. Aangezien de werkzoekenden die ingedeeld zijn in fase 4 op korte termijn niet in aanmerking komen voor scholing, worden zij in dit hoofdstuk buiten beschouwing gelaten.

72. Dit raamwerk is vergelijkbaar met het raamwerk dat in hoofdstuk 2 gebruikt is om de actuele discrepanties in kaart te brengen. De Indicator Toekomstige Knelpunten Personeelsvoorziening is vergelijkbaar met de indicator voor de arbeidsmarktkrapte, terwijl de indicator van het bijscholingspotentieel in verhouding tot de omvang van de scholingsbehoefte het equivalent is van de knelpuntsindicator. 
Een ruime arbeidsmarkt wordt gekenmerkt door een verwacht overschot aan direct inzetbare werkzoekenden. De Indicator Toekomstige Knelpunten Personeelsvoorziening is groter dan één. Dit betekent dat voor werkzoekenden met een grotere afstand tot de arbeidsmarkt de perspectieven voor 1998 gering zijn. Bijscholing (in ruime zin) zal op de korte termijn niet tot een vergroting van de arbeidsmarktkansen leiden. In deze arbeidsmarktsituatie is ook voor direct inzetbare werkzoekenden - schoolverlaters en werkzoekenden in fase 1 - het perspectief minder gunstig. Omscholing kan een middel zijn om voor deze werkzoekenden de arbeidsmarktkansen te vergroten.

\section{Een krappe arbeidsmarkt met een kwantitatief tekort.}

Wanneer er sprake is van een tekort aan direct inzetbare werkzoekenden, terwijl er op het betreffende arbeidsmarktsegment ook onvoldoende werkzoekenden met een wat grotere afstand tot de arbeidsmarkt (in fase 2 of 3) beschikbaar zijn, is er sprake van een kwantitatief probleem. Er zijn eenvoudigweg te weinig werkzoekenden in het betreffende segment beschikbaar om in de totale behoefte te voorzien. Dit betekent wel dat door middel van bijscholing de beschikbare werkzoekenden in fase 2 en 3 relatief snel aan een baan kunnen worden geholpen. Dit betekent dat de bijscholingsmogelijkheden voor deze nietdirect bemiddelbare werkzoekenden groot zijn. Bijscholing is echter geen adequaat middel om de verwachte knelpunten op het betreffende arbeidsmarktsegment geheel het hoofd te bieden. De vraag zal het aanbod van arbeidskrachten blijven overtreffen. Omscholingsprogramma's voor werkzoekenden in verwante arbeidsmarktsegmenten waarin er sprake is van een ruime markt zijn derhalve noodzakelijk om in de totale vraag te voorzien.

\section{Een krappe arbeidsmarkt met een kwalitatief aansluitingsprobleem.}

Wanneer het direct inzetbare aanbod tekortschiet om de verwachte baanopeningen in te vullen, maar er voldoende werkzoekenden in fase 2 en 3 op zoek zijn naar een baan in het betreffende segment, is er sprake van een kwalitatief aansluitingsprobleem. In die situatie is bijscholing een effectief middel om in de vraag te voorzien. Gezien het grote aantal werkzoekenden in fase 2 en 3 zijn de bijscholingsmogelijkheden voor de werkzoekenden zelf echter relatief beperkt. De scholingsbehoefte aan de vraagkant van de arbeidsmarkt is relatief klein vergeleken met het aantal werkzoekenden in fase 2 en 3 . Slechts een deel van de werkzoekenden met een wat grotere afstand tot de arbeidsmarkt kan via bijscholings- en begeleidingsprogramma's aan een baan worden geholpen. Scholing zal de werkloosheidsproblematiek in het betreffende segment dus slechts in beperkte mate verminderen.

Het hierboven geschetste raamwerk biedt de mogelijkheid de implicaties van de in 1998 
verwachte knelpunten op de arbeidsmarkt voor het scholingsbeleid in kaart te brengen ${ }^{73}$. De opzet van dit hoofdstuk is als volgt. In paragraaf 6.2 wordt nader ingegaan op de scholingsbehoefte aan de vraagkant van de arbeidsmarkt. In paragraaf 6.3 wordt vervolgens, analoog aan de analyse van de actuele discrepanties in paragraaf 2.5 , een typering gegeven van de verwachte arbeidsmarktsituatie in 1998. In paragraaf 6.4 wordt aandacht geschonken aan het gewenste karakter van de scholingsbehoefte in het licht van de arbeidsmarktsituatie en de gevraagde vaardigheden op de betreffende arbeidsmarktsegmenten. Dit hoofdstuk wordt in paragraaf 6.5 afgesloten met een aantal aandachtspunten voor het scholingsbeleid.

\subsection{Scholingsbehoefte op de Limburgse arbeidsmarkt}

Krappe en ruime arbeidsmarktsegmenten

Aangezien de ernst van de knelpunten in de personeelsvoorziening een belangrijke determinant van de scholingsbehoefte vormt, vormt het onderscheid tussen krappe en ruime arbeidsmarkten een geschikt startpunt voor het in kaart brengen van de scholingsbehoefte op de Limburgse arbeidsmarkt in 1998. De Indicator Toekomstige Knelpunten in de Personeelsvoorziening (ITKP) geeft per opleidingstype een indicatie van de eventuele tekorten aan direct inzetbare werkzoekenden - schoolverlaters en niet-werkende werkzoekenden in fase 1 - in 1998. Wanneer de ITKP voor een bepaalde opleiding groter is dan één, dan wordt er voor deze opleiding een ruime arbeidsmarkt verwacht. Er zal dan naar verwachting sprake zijn van hooguit enige knelpunten. In veel gevallen zullen werkgevers (vrijwel) niet met knelpunten geconfronteerd worden. Wanneer de ITKP daarentegen kleiner is dan één, dan zal er sprake zijn van een krappe arbeidsmarkt met grote tot zeer grote knelpunten. Het aantal direct inzetbare werkzoekenden schiet dan tekort om in de totale vraag op dat arbeidsmarktsegment in 1998 te voorzien.

De ITKP maakt het dus mogelijk een onderscheid te maken tussen ruime en krappe arbeidsmarktsegmenten. In hoofdstuk 3 is reeds aandacht geschonken aan de verwachte knelpunten in de personeelsvoorziening. In tabel 6.1 wordt een overzicht gegeven van de opleidingstypen waarvoor een krappe arbeidsmarkt in 1998 verwacht wordt ${ }^{74}$. Bij vacatures waarvoor gezocht wordt naar iemand met een opleidingsachtergrond die in de tabel wordt genoemd, zullen werkgevers in 1998 naar verwachting moeite hebben deze vacatures te

73. In hoofdstuk 3 is reeds aangegeven dat de regionale ITKP alleen voor opleidingen op VBO- en MBO/Leerlingwezen-niveau berekend is. Twee argumenten liggen hieraan ten grondslag. In de eerste plaats is met name op deze niveaus sprake van een regionale arbeidsmarkt. In de tweede plaats speelt vooralsnog het gebrek aan betrouwbare cijfers over de arbeidsmarktinstroom van schoolverlaters een rol.

74. In tabel 6.1 en in de rest van dit hoofdstuk wordt alleen aandacht geschonken aan opleidingstypen wanneer er meer dan 2.500 mensen met deze opleidingsachtergrond in Limburg werkzaam zijn. 
Tabel 6.2

Verwachte scholingsbehoefte naar opleidingstype in 1998 in Limburg

\begin{tabular}{|c|c|c|c|}
\hline Opleidingstype & $\begin{array}{l}\text { scholings- } \\
\text { behoefte }\end{array}$ & $\begin{array}{l}\text { huidig } \\
\text { aantal } \\
\text { werkenden }\end{array}$ & beroepsgroep \\
\hline MBO/LLW verpleging & 400 & 9.000 & verplegenden \\
\hline MBO/LLW bouw & 350 & 8.000 & bouwvakkers, installateurs \\
\hline MBO/LLW motorvoertuigentechniek & 250 & 5.000 & monteurs \\
\hline MBO/LLW procestechniek & 250 & 4.000 & procesoperators \\
\hline MBO/LLW vervoer & 200 & 3.000 & - \\
\hline MBO/LLW landbouw en veeteelt & 200 & 6.500 & agrarische arbeiders \\
\hline MBO/LLW bedrijfskunde & 150 & 2.500 & - \\
\hline MBO/LLW horeca & 150 & 6.500 & horeca-functies \\
\hline MBO/LLW elektrotechniek & 100 & 11.000 & elektromonteurs \\
\hline MBO openbare orde en veiligheid & 100 & 6.000 & beveiligingsemployés \\
\hline MBO/LLW secretariaat & 100 & 6.500 & secretaresses \\
\hline MBO automatisering & 50 & 3.000 & programmeurs \\
\hline
\end{tabular}

Bron: ROA

In tabel 6.2 wordt een overzicht gegeven van de scholingsbehoefte vanuit de vraagzijde van de Limburgse arbeidsmarkt in 1998. Uit de tabel blijkt dat de scholingsbehoefte ter voorkoming van knelpunten in de personeelsvoorziening zich naar verwachting geheel concentreert op opleidingen op MBO/Leerlingwezen-niveau. De scholingsbehoefte is het grootst voor het opleidingstype MBO/LLW verpleging. Door middel van het scholen van 400 werkzoekenden kan het verwachte tekort aan direct inzetbare werkzoekenden met deze opleidingsachtergrond worden voorkomen. Hier is het vooral de omvang van de markt - er zijn 9.000 mensen met deze opleidingsachtergrond werkzaam in Limburg - die ten grondslag ligt aan de grote scholingsbehoefte ${ }^{75}$. Ook bij de opleidingsrichtingen bouw en elektrotechniek wordt de scholingsbehoefte in belangrijke mate door de omvang van de markt bepaald. Met name bij de opleidingsrichting procestechniek wordt de omvang van scholingsbehoefte daarentegen bepaald door de verwachte knelpunten.

In tabel 6.2 wordt tevens aangegeven op welke beroepsgroepen de scholingsbehoefte met name betrekking heeft. Zo heeft de scholingsbehoefte voor het opleidingstype MBO/LLW procestechniek voornamelijk betrekking op het voorkomen van knelpunten in de beroepsgroep procesoperators. De verschillende ETIL-onderzoeken geven aan dat ook voor een aantal andere beroepsgroepen in de handel en industrie knelpunten bestaan of

75. Hierbij dient de kanttekening geplaatst te worden dat de mogelijkheden om de tekorten in de verpleging te verminderen in belangrijke mate beïnvloed worden door de invulling van het overheidsbeleid in de gezondheidszorg. 
verwacht worden ${ }^{76}$. Het gaat hier met name om de grafische vakkrachten, de bankwerkers en lassers, de verkopers, de commercieel employés en de chauffeurs. Daarnaast worden knelpunten ervaren bij het vinden van productiemedewerkers en vakkenvullers. Een tekort aan geschikte arbeidskrachten voor deze laatste twee beroepsgroepen leidt echter in mindere mate tot een scholingsbehoefte, aangezien de beroepen een elementair karakter hebben en geen scholing vereist is.

Tabel 6.3 geeft een overzicht van de vraaggerichte scholingsinspanningen van Arbeidsvoorziening Limburg in $1997^{77}$. Uit de tabel blijkt dat er in totaal 2.325 trajecten gepland zijn. Hiervan is overigens ruim een kwart aanbodgericht. Een vergelijking met tabel 6.2 laat enkele opmerkelijke verschillen zien. Met name de beroepsgroep zorg lijkt enigszins ondervertegenwoordigd. Uit tabel 6.2 blijkt dat er in 1998 in Limburg bijvoorbeeld behoefte is aan 400 extra mensen met een opleiding verpleging, terwijl er in 1997 slechts 200 trajecten in de beroepsgroep zorg worden gerealiseerd ${ }^{78}$.

Tabel 6.3

Scholingsinspanningen 1997 Arbeidsvoorziening Limburg

Beroepsgroep/richting aantal

trajecten

$\begin{array}{lr}\text { Techniek } & 1.100 \\ \text { Commercieel } & 300 \\ \text { Zorg } & 200 \\ \text { Administratief } & 300 \\ \text { Overig } & 425 \\ & \\ \text { Totaal } & 2.325\end{array}$

Bron: Arbeidsvoorziening Limburg

\subsection{Het bijscholingspotentieel in verhouding tot de bijscholingsbehoefte}

Bijscholing kan een belangrijk instrument zijn om de arbeidsmarktkansen van

76. Van Camp, H., 1997a, op cit. en Van Camp, H., 1997b, op cit.

77. Regionaal Bestuur voor de Arbeidsvoorziening Limburg, Scholingsplan 1998 Arbeidsvoorziening Limburg, 1997

78. Overigens dient opgemerkt te worden dat scholing in dit kader een breed begrip is. Dit betekent dat de behoefte ook betrekking kan hebben op niet rechtstreeks aan het beroep gerelateerde scholing. Dit betekent echter ook dat er allerlei vormen van scholing denkbaar zijn, waaronder een formeel scholingstraject, maar ook bijvoorbeeld on-the-job training. 
werkzoekenden die niet direct inzetbaar zijn te vergroten. De verwachte knelpunten in de personeelsvoorziening spelen vanzelfsprekend een belangrijke rol voor de bijscholingsmogelijkheden voor deze werkzoekenden. Wanneer er sprake is van een ruime arbeidsmarkt zijn er immers voldoende direct inzetbare werkzoekenden beschikbaar, waardoor scholing van de niet-direct inzetbare werkzoekenden weinig perspectiefvol is. Wanneer er daarentegen op een bepaald arbeidsmarktsegment sprake is van een krapte en er grote knelpunten in de personeelsvoorziening verwacht worden, kan scholing werkzoekenden met een grotere afstand tot de arbeidsmarkt een goed perspectief bieden op het vinden van werk.

Naast de vraag of er sprake is van verwachte knelpunten, speelt ook de aard van de knelpunten een rol. Wanneer voor een bepaald opleidingstype, waarvoor er sprake is van knelpunten in de personeelsvoorziening, ook het aantal werkzoekenden met een wat grotere afstand tot de arbeidsmarkt tekortschiet om de baanopeningen die niet door schoolverlaters en werkzoekenden in fase 1 kunnen worden vervuld in te vullen, dan is er, zoals reeds aangegeven in paragraaf 6.1 , sprake van een kwantitatief tekort aan werkzoekenden. In dat geval zullen de bijscholingsmogelijkheden voor werkzoekenden in fase 2 en 3 naar verwachting groot zijn. De verhouding tussen het aantal niet-direct inzetbare werkzoekenden en de totale vraag die niet door schoolverlaters en werkzoekenden in fase 1 kan worden vervuld is dan kleiner dan één.

In tabel 6.4 wordt een overzicht gegeven van de opleidingstypen die gekenmerkt worden door goede bijscholingsmogelijkheden voor werkzoekenden met een grotere afstand tot de arbeidsmarkt. Uit de tabel blijkt dat de bijscholingsmogelijkheden voor de niet-direct bemiddelbare werkzoekenden het grootst zijn voor degenen met een opleidingsachtergrond MBO/LLW bedrijfskunde. Voor elke honderd baanopeningen die niet door schoolverlaters of direct bemiddelbare werkzoekenden kunnen worden vervuld, zijn slechts twee niet-direct inzetbare werkzoekenden beschikbaar. Gezien het kwantitatieve karakter van het aansluitingsprobleem - er zijn eenvoudigweg te weinig werkzoekenden met de betreffende opleidingsachtergrond beschikbaar - zijn de bijscholingsmogelijkheden voor deze werkzoekenden groot. Bijscholing is een effectief middel om de arbeidsmarktkansen van deze werkzoekenden te vergroten.

Hiermee is echter niet duidelijk welk karakter deze bijscholing dient te hebben. Met andere woorden: de onderliggende oorzaken van het feit dat deze werkzoekenden een grotere afstand tot de arbeidsmarkt hebben worden uit deze cijfers niet duidelijk. In het ETILonderzoek is echter zowel in de telefonische enquête als in de diepte-interviews met de bedrijven gevraagd wat de belangrijkste oorzaken zijn van de moeilijk vervulbare vacatures in de handel en industrie ${ }^{79}$. Bij de middelbare technische functies, zoals de procesoperators,

79. Zie Van Camp, H., 1997a, op cit. en Van Camp, H., 1997b, op cit. 
worden zowel het te lage opleidingsniveau als de te geringe werkervaring genoemd als een oorzaak van het moeilijk kunnen vervullen van de vacatures. Voor het te voeren arbeidsvoorzieningsbeleid betekent dit dat niet alleen aanvullende scholing, maar ook het creëren van mogelijkheden om op de werkvloer ervaring op te doen belangrijk is om het beschikbare aanbod van werkzoekenden direct bemiddelbaar te maken. Bij de werkzoekende bouwvakkers ontbreekt vooral de vereiste werkervaring. Ook in dit geval is het creëren van mogelijkheden om in de praktijk werkervaring op te doen een geschikt instrument. De monteurs hebben daarentegen vaak niet de juiste opleidingsrichting voor de moeilijk vervulbare vacatures. Aanvullende cursussen om de kennis te verbreden zijn hier dus gewenst.

Tabel 6.4

Opleidingstypen met naar verwachting goede bijscholingsmogelijkheden (BSM) voor individuele werkzoekenden in 1998 in Limburg

\begin{tabular}{llll}
\hline Opleidingstype & BSM & beroepsgroep & aard bijscholing \\
\hline MBO/LLW bedrijfskunde & 0,02 & - & - \\
MBO/LLW procestechniek & 0,05 & procesoperators & $\begin{array}{l}\text { niveau verhogen } \\
\text { ervaring opdoen }\end{array}$ \\
MBO/LLW bouw & 0,13 & bouwvakkers, installateurs & $\begin{array}{l}\text { ervaring opdoen } \\
\text { vakkennis verbreden }\end{array}$ \\
MBO/LLW motorvoertuigentechn. & 0,15 & monteurs & vakkennis verbreden \\
MBO/LLW elektrotechniek & 0,19 & elektromonteurs & - \\
MBO/LLW landbouw en veeteelt & 0,29 & agrarische arbeiders & - \\
MBO/LLW vervoer & 0,35 & - & - \\
MBO/LLW verpleging & 0,35 & verplegenden & - \\
MBO openbare orde en veiligheid & 0,48 & beveiligingsemployés & - \\
MBO/LLW horeca & 0,49 & horecafuncties & -
\end{tabular}

Bron: ROA

Knelpunten in de personeelsvoorziening kunnen ook het gevolg zijn van een kwalitatief aansluitingsprobleem bij een bepaald opleidingstype. In dat geval zijn er voor dat opleidingstype voldoende werkzoekenden in fase 2 en 3 beschikbaar om de baanopeningen die niet door schoolverlaters en werkzoekenden in fase 1 kunnen worden vervuld in te vullen. Er zijn dan weliswaar genoeg werkzoekenden beschikbaar, maar deze voldoen niet aan de eisen die op het betreffende arbeidsmarktsegment worden gesteld. Het probleem is kwalitatief van aard. De indicator voor het bijscholingspotentieel in verhouding tot de scholingsbehoefte is dan groter dan één. Slechts een deel van de werkzoekenden in fase 2 en 3 zal door bijscholing een baan kunnen krijgen

In tabel 6.5 wordt een overzicht gegeven van de opleidingstypen waarvoor er sprake is van een kwalitatief aansluitingsprobleem en de bijscholingsmogelijkheden voor individuele werkzoekenden die zijn ingedeeld in fase 2 of 3 dus relatief beperkt zijn. Uit de tabel blijkt dat deze situatie zich in 1998 naar verwachting slechts voor twee opleidingstypen zal voordoen. Bij MBO/LLW secretariaat zijn er voor elke 100 baanopeningen, die niet door 
direct inzetbare werkzoekenden kunnen er worden ingevuld, 182 werkzoekenden in fase 2 en 3 beschikbaar. Van deze 182 werkzoekenden kunnen er dus naar verwachting 100 door middel van bijscholing aan het werk worden geholpen. Wat dit betreft is het opmerkelijk dat in het ETIL-onderzoek, waarin verslag wordt gedaan van een aantal diepte-interviews met bedrijven, blijkt dat een tekort aan gekwalificeerde secretaresses als belangrijkste oorzaak voor het moeilijk vervulbaar zijn van vacatures voor deze beroepsgroep wordt genoemd ${ }^{80}$. Blijkbaar hebben de niet direct inzetbare werkzoekenden een dermate grote afstand tot de arbeidsmarkt dat zij door de vraagzijde van de markt zelfs niet als potentieel aanbod worden beschouwd. Dit betekent dat de te verrichten scholingsinspanningen per werkzoekende in dit segment aanzienlijk dienen te zijn. Aangezien in de diepte-interviews aangegeven wordt dat er te weinig aanbod is, gaat het hier waarschijnlijk vooral om herintreders die qua kennis en vaardigheden niet goed inzetbaar zijn in de openstaande vacatures voor secretariaatsfuncties. De bijscholing van deze werkzoekenden zal waarschijnlijk met name moeten worden gericht op het kunnen werken met tekstverwerkingspakketten en andere relevante softwarepakketten. $\mathrm{Bij}$ MBO/LLW automatisering zullen er voor elke 100 baanopeningen die niet door direct inzetbare werkzoekenden kunnen worden ingevuld 252 niet direct inzetbare werkzoekenden beschikbaar zijn.

Tabel 6.5

Opleidingstypen met naar verwachting grote knelpunten in de personeelsvoorziening, maar beperkte bijscholingsmogelijkheden (BSM) voor individuele werkzoekenden in 1998 in Limburg

\begin{tabular}{llll}
\hline Opleidingstype & BSM & beroepsgroep & aard bijscholing \\
\hline MBO/LLW secretariaat & 1,82 & secretaresses & kennis actualiseren \\
MBO/LLW automatisering & 2,52 & programmeurs & -
\end{tabular}

Bron: ROA

\subsection{Karakter van de scholingsbehoefte}

Naast de in paragraaf 6.2 besproken omvang van de scholingsbehoefte is ook van belang waar de werkzoekenden die voor scholing in aanmerking komen gevonden kunnen worden. Hierbij kan, zoals bij de bijscholingsmogelijkheden voor werkzoekenden, een onderscheid gemaakt worden tussen opleidingstypen waarvoor er sprake is van een kwalitatief aansluitingsprobleem en opleidingstypen die gekenmerkt worden door een kwantitatief aanbodtekort. Wanneer er sprake is van een kwalitatief aansluitingsprobleem kan de nadruk liggen op bijscholing van niet-direct inzetbare werkzoekenden in het eigen segment. Dit is het geval voor de in tabel 6.5 genoemde opleidingstypen $M B O / L L W$ secretariaat en MBO/LLW automatisering. Er zijn voldoende werkzoekenden in fase 2 en 3 met deze opleidingsachtergrond beschikbaar om het tekort aan schoolverlaters en werkzoekenden in fase 1 met deze opleidingsachtergrond te bestrijden door middel van bijscholing. Bij het

80. Zie Van Camp, H., 1997b, op cit. 
opleidingstype MBO/LLW automatisering gaat het vooral om programmeurs, terwijl het bij de opleidingsachtergrond MBO/LLW secretariaat met name werkenden in secretaresse-functies betreft.

Wanneer er sprake is van een kwantitatief aansluitingsprobleem is bijscholing van de nietdirect inzetbare werkzoekenden met de betreffende opleidingsachtergrond niet toereikend om de verwachte knelpunten in de personeelsvoorziening te voorkomen. In dat geval is omscholing van werkzoekenden met een enigszins verwante opleidingsachtergrond noodzakelijk om in de vraag te voorzien. Deze mensen zullen moeten worden aangetrokken uit arbeidsmarktsegmenten waarvoor geen knelpunten in de personeelsvoorziening verwacht worden. Het omscholen van arbeidskrachten uit segmenten waarvoor eveneens sprake is van knelpunten is immers weinig efficiënt.

Tabel 6.6

Mogelijkheden ter voorkoming van de knelpunten in de personeelsvoorziening door middel van omscholing in 1998 in Limburg

\begin{tabular}{lll} 
Opleidingstype & omscholing vanuit & beroepsgroep \\
\hline & & \\
MBO/LLW verpleging & - & verplegenden \\
MBO/LLW bouw & VBO bouwtechniek & bouwvakkers \\
& VBO installatietechniek & installateurs \\
MBO/LLW motorvoertuigentechn. & VBO motorvoertuigentechniek & monteurs \\
MBO/LLW procestechniek & VBO mechanische techniek & procesoperators \\
MBO/LLW vervoer & - & - \\
MBO/LLW landbouw en veeteelt & VBO landbouw en natuurlijke & \\
& omgeving & agrarische arbeiders \\
MBO/LLW bedrijfskunde & - & - \\
MBO/LLW horeca & VBO horeca en levensmiddelen- & \\
MBO/LLW elektrotechniek & techniek & horecafuncties \\
MBO openbare orde en veiligheid & - & elektromonteurs \\
\end{tabular}

Bron: ROA

In tabel 6.6 wordt voor de opleidingstypen die naar verwachting in 1998 te kampen zullen hebben met een kwantitatief aanbodtekort aangegeven welke werkzoekenden met een verwante opleidingsachtergrond voor omscholing in aanmerking zouden kunnen komen. Tevens wordt aangegeven op welke beroepsgroepen deze scholing gericht zou dienen te zijn. Uit de tabel blijkt dat de gewenste omscholing in de meeste gevallen betrekking heeft op het scholen van werkzoekenden met een VBO-opleidingsachtergrond voor banen op $\mathrm{MBO} /$ Leerlingwezen-niveau. Hierbij zal vooral gedacht moeten worden aan het scholen van werkzoekenden in fase 1, aangezien de vereiste niveauverhogende scholing een aanzienlijke inspanning van de werkzoekenden zal vragen. Het gaat hierbij vooral om een aantal technische opleidingen. Uit het onderzoek van het ETIL blijkt dat er in de industrie veel moeilijk vervulbare vacatures voor monteurs bestaan, waarvoor een tekortschietend 
aanbod als belangrijkste oorzaak wordt beschouwd ${ }^{81}$. De geïnterviewde bedrijven onderstrepen het belang van scholing om het tekortschietende aanbod voor monteursfuncties te ondervangen. De opleidingen op het niveau van MBO/LLW elektrotechniek vormen een belangrijke rekruteringsbron voor werkgevers die op zoek zijn naar (elektro)monteurs. Door aanvullende scholingstrajecten voor werkzoekenden met een opleiding VBO elektrotechniek zou kunnen worden ingespeeld op de verwachte knelpunten in de personeelsvoorziening voor vakmensen met een opleiding elektrotechniek op MBO/Leerlingwezen-niveau. Daarnaast komen ook de VBO'ers met een agrarische of horeca-opleidingsachtergrond voor scholing in aanmerking. Zo zouden de knelpunten voor de horeca-opleidingen op MBO-niveau door het aanbieden van scholingstrajecten aan VBO'ers vermeden kunnen worden.

De nadruk op het scholen van arbeidskrachten met een VBO-opleidingsachtergrond betekent overigens niet dat er voor MBO-opleidingen waarvoor knelpunten in de personeelsvoorziening worden verwacht geen verwante richtingen op MBO/Leerlingwezenniveau te vinden zijn. Vaak worden er voor deze opleidingstypen echter ook knelpunten in de personeelsvoorziening verwacht. Zo vertoont het werkveld van degenen met de opleidingsachtergrond MBO/LLW landbouw en veeteelt een grote verwantschap met het beroependomein van degenen met een opleiding MBO/LLW milieu en groene ruimte. Voor dit laatstgenoemde opleidingstype worden echter in 1998 ook grote knelpunten in de personeelsvoorziening verwacht ${ }^{82}$.

Voor een aantal opleidingstypen zijn geen werkzoekenden uit verwante opleidingstypen beschikbaar. Voor deze opleidingstypen biedt scholing op de korte termijn geen soelaas om de knelpunten in de personeelsvoorziening te verminderen. Dit kan twee oorzaken hebben. Ten eerste kan er bij verwante opleidingstypen ook sprake zijn van knelpunten in de personeelsvoorziening. Zo is het opleidingstype MBO dokters-, dieren- en tandartsassistent nauw verwant aan het opleidingstype MBO/LLW verpleging. Beide opleidingstypen zullen in 1998 echter naar verwachting worden gekenmerkt door grote knelpunten in de personeelsvoorziening. Omscholing van werkzoekenden met een opleiding dokters-, dierenen tandartsassistent, om de knelpunten in de personeelsvoorziening voor MBO/LLW verpleging te bestrijden, zou echter de knelpunten voor de genoemde assistentenopleidingen alleen nog maar vergroten. Dit betekent dat scholing op de korte termijn waarschijnlijk weinig soelaas biedt om de verwachte tekorten aan verpleegkundigen te voorkomen, tenzij mensen kunnen worden geworven uit de zogenaamde 'stille reserve' van mensen die zich niet op de arbeidsmarkt aanbieden. In dat geval zal de scholing met name gericht moeten worden op het bijscholen en opfrissen van de kennis en vaardigheden

81. Van Camp, H., 1997d, op cit.

82. Opgemerkt dient te worden dat aan deze knelpunten de verwachte groei in de werkgelegenheid in de relevante bedrijfssectoren (met name landbouw en visserij, en de voedings- en genotsmiddelenindustrie) ten grondslag ligt. Aangezien in deze werkgelegenheidsprognoses de eventuele negatieve effecten van de varkenspest niet zijn verwerkt, kan er hier sprake zijn van een overschatting van de scholingsbehoefte. 
van herintreders, die de laatste tijd niet meer in hun vakgebied werkzaam zijn geweest.

\subsection{Aandachtspunten voor het scholingsbeleid}

Bij- en omscholing van werkzoekenden kan een effectief middel zijn om discrepanties tussen vraag en aanbod op de arbeidsmarkt te verminderen. Door middel van bijscholing kunnen aansluitingsproblemen tussen de kennis en vaardigheden waarover de werkzoekenden in een bepaald arbeidsmarktsegment beschikken en de in dat segment gevraagde kennis en vaardigheden verminderd worden. Met andere woorden: bijscholing kan een effectief middel zijn om kwalitatieve aans/uitingsproblemen in een bepaald arbeidsmarktsegment het hoofd te bieden. Door middel van omscholing kunnen knelpunten op de arbeidsmarkt, die hun oorsprong vinden in het feit dat er in een specifiek arbeidsmarktsegment geen werkzoekenden beschikbaar zijn om aan de vraag te voldoen, verminderd worden. Omscholing van werkzoekenden met een opleidingsachtergrond waarvoor er sprake is van een overschot, kan dus een effectief middel zijn om kwantitatieve aansluitingsproblemen op andere arbeidsmarktsegmenten te verminderen.

Aansluitingsproblemen hebben overigens niet alleen betrekking op vakinhoudelijke kennis en vaardigheden. Ook werkhouding, communicatieve vaardigheden, de wil om te blijven leren, een klantvriendelijke instelling, e.d. spelen een belangrijke rol.

De scholingsbehoefte zal zich naar verwachting geheel concentreren op het vergroten van het direct inzetbare arbeidsaanbod op MBO/Leerlingwezenniveau. Voor de opleidingstypen MBO automatisering en MBO/LLW secretariaat geldt dat er met name sprake is van kwalitatieve discrepanties. Voor beide opleidingstypen is er sprake van een tekort aan direct inzetbare werkzoekenden. Bijscholing van werkzoekenden met een grotere afstand tot de arbeidsmarkt zou hier de in 1998 verwachte knelpunten in de personeelsvoorziening kunnen voorkomen. Met name de bijscholing van werkzoekenden met MBO/LLW secretariaat - met als doel het tekort aan secretaresses te verminderen - zal aanzienlijke inspanningen vergen. Hierbij gaat het met name om het actualiseren van de kennis en vaardigheden van herintreders.

Voor een aantal MBO/Leerlingwezen-opleidingstypen wordt een kwantitatief aansluitingsprobleem verwacht. Zo wordt er in 1998 een tekort van 400 aan direct inzetbaar aanbod van verplegenden verwacht; een tekort van 350 bouwvakkers en installateurs op MBO-niveau en een tekort van 250 procesoperators. In deze gevallen zal alleen een combinatie van bij- en omscholingstrajecten soelaas kunnen bieden. Tabel 6.7 geeft een samenvattend overzicht van de gewenste aandachtspunten voor het scholingsbeleid in 1998, verbijzonderd naar de opleidingstypen waarop de scholing zich zou moeten richten, de beroepsgroepen waarvoor ze opleiden, de aard van de gewenste bijscholing en de werkzoekenden met een verwante opleidingsachtergrond die voor omscholing in aanmerking komen.

De verschillende ETIL-onderzoeken geven aan dat er ook voor een aantal andere 
beroepsgroepen in de handel en industrie knelpunten in de personeelsvoorziening bestaan of verwacht worden ${ }^{83}$. Het gaat hier met name om grafische vakkrachten, bankwerkers en lassers, verkopers, commercieel employés en chauffeurs. Daarnaast worden knelpunten ervaren in het vinden van productiemedewerkers en vakkenvullers. Gezien het elementaire karakter van de laatste twee beroepen, zal de scholingsbehoefte hier vooral betrekking hebben op de werkhouding en communicatieve vaardigheden.

83. Van Camp, H., 1997a, op cit., Van Camp, H., 1997b, op cit., Van Camp, H., 1997c, op cit. en Van Camp, H., 1997d, op cit. 


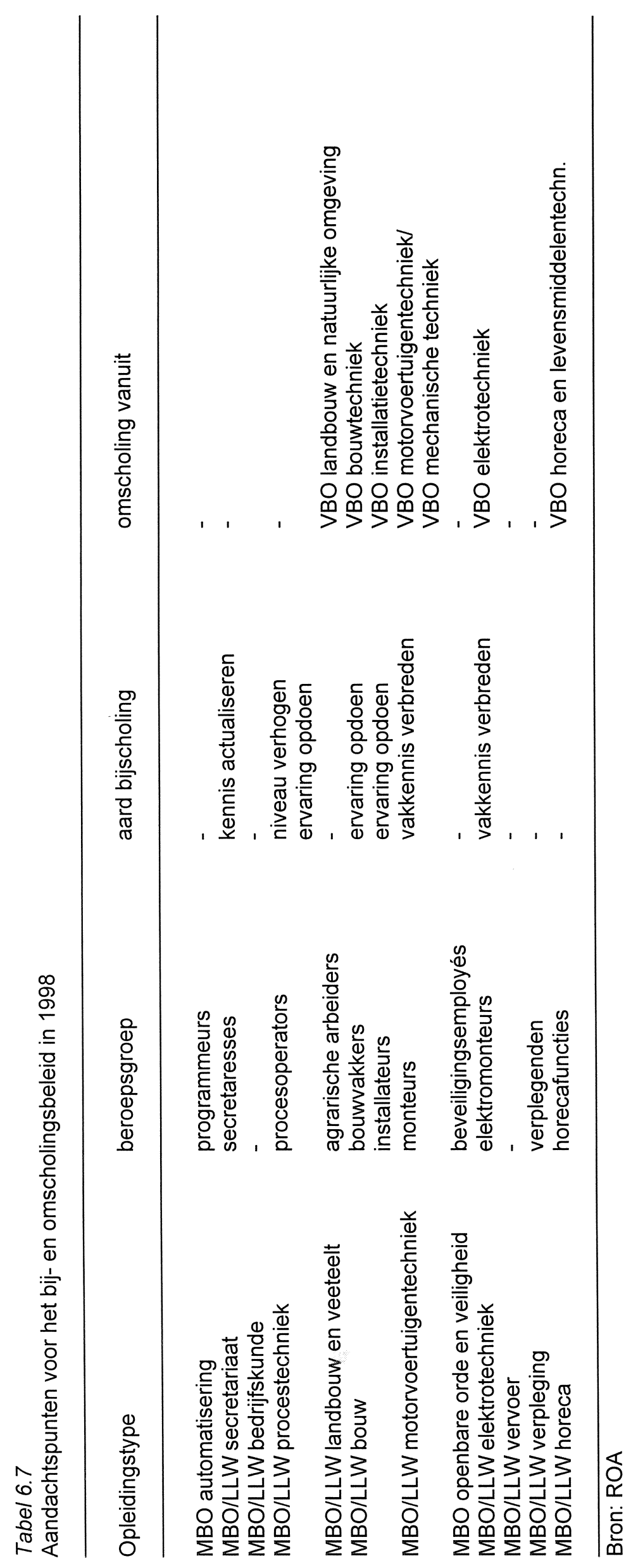




\subsection{Inleiding}

Voor schoolverlaters is de initiële opleidingskeuze niet alleen voor een groot deel bepalend voor de eerste baan, maar ook voor het verdere loopbaanperspectief. Voor de vraagzijde van de arbeidsmarkt - de werkgevers - vormen schoolverlaters een belangrijke groep waaruit nieuwe arbeidskrachten worden gerekruteerd. In de hoofdstukken 3 en 4 is reeds aandacht geschonken aan het toekomstig arbeidsmarktperspectief van de verschillende opleidingen op de Limburgse arbeidsmarkt. Dit hoofdstuk plaatst deze toekomstige perspectieven in een breder kader. Daarbij staat de rol van het initiële onderwijs centraal. Aangezien schoolverlaters van nieuwe of vernieuwde opleidingen pas na een aantal jaren zullen instromen op de arbeidsmarkt, zullen investeringen in het initiële onderwijs pas na een aantal jaren effect hebben op de arbeidsmarktinstroom. Daarom wordt in dit hoofdstuk de nadruk gelegd op de perspectieven op de middellange termijn. Vanuit het oogpunt van de zogenaamde macrodoelmatigheid van het onderwijs is het wenselijk de instroom in opleidingstypen met goede of zeer goede arbeidsmarktperspectieven te bevorderen. Het zonder meer vergroten van het onderwijsaanbod zal echter niet altijd de gewenste effecten sorteren. Een vergroting van de opleidingscapaciteit garandeert immers niet dat deze capaciteit ook benut zal worden. Een verruimde geografische spreiding of de introductie van een opleidingsvariant die op dat moment nog niet wordt aangeboden, zal doorgaans wel de instroom voor het desbetreffende opleidingstype verhogen, doordat mobiliteitsdrempels worden weggenomen of beter ingespeeld kan worden op de interesse of capaciteiten van leerlingen.

Een vraag die zich voordoet bij een dergelijke uitbreiding van het onderwijsaanbod is echter welke leerlingen hiermee worden aangetrokken. Als een verhoogde geografische spreiding er alleen toe leidt dat leerlingen dezelfde opleiding minder ver van huis kunnen volgen, of als de extra belangstelling voor een nieuwe opleiding met goede perspectieven leerlingen trekt die anders een opleiding met zeer goede perspectieven hadden gekozen is de 'macrodoelmatigheid' van de nieuwe opleiding ondanks de gunstige arbeidsmarktperspectieven beperkt.

Nieuw aanbod van opleidingen zal daarom met name baat hebben wanneer er leerlingen worden aangetrokken die anders een opleiding zouden kiezen met duidelijk slechtere perspectieven. Zo kan de keuze voor opleidingen met slechte perspectieven het gevolg zijn van geografische belemmeringen. Ook kan de oorzaak liggen in de capaciteiten en interesse van de leerlingen. Een nieuwe opleiding die door het aanbieden van een leerweg voor leerlingen met beperkte capaciteiten, deze leerlingen toch adequaat opleidt in een richting met goede perspectieven, kan in dat opzicht een zeer waardevolle aanvulling zijn van het opleidingsaanbod. Op vergelijkbare wijze kan een nieuwe opleiding in een richting met goede perspectieven, die door een andere invulling van het onderwijs meer belangstelling van een bepaalde groep leerlingen weet te wekken, een verhoogde instroom bewerkstelligen. Een duidelijk voorbeeld daarvan zijn technische opleidingen met (zeer) 
goede arbeidsmarktperspectieven die meer meisjes weten aan te trekken. Vanuit deze optiek is het overigens niet in de eerste plaats van belang dat er sprake is van een zeer goed arbeidsmarktperspectief, maar wordt de aansluiting onderwijs-arbeidsmarkt met name verbeterd als leerlingen die aanvankelijk zouden kiezen voor een richting met minder goede perspectieven nu kiezen voor een opleiding met een beter perspectief.

Naast het arbeidsmarktperspectief, dat gebaseerd is op de verwachte ontwikkelingen in vraag en aanbod, kan het onderwijsbeleid ook de structurele positie van opleidingen als richtlijn nemen. Een tweetal risico-indicatoren is op dit punt van belang: de conjunctuurgevoeligheid van de werkgelegenheid en de uitwijkmogelijkheden naar verschillende beroepsgroepen. Zo zijn er bepaalde opleidingen die een hoge mate van conjunctuurgevoeligheid combineren met beperkte uitwijkmogelijkheden. Veranderingen in het onderwijs, waardoor de opleiding verbreedt en daardoor toegang verschaft tot een breder beroependomein, kan deze kwetsbaarheid verminderen. Omgekeerd kunnen ontwikkelingen aan de vraagkant van de arbeidsmarkt leiden tot een behoefte aan personeel met zeer specifieke vaardigheden. Hierdoor kan het wenselijk zijn een meer specialistische opleiding te starten. Hierbij dient altijd wel overwogen te worden in hoeverre de vraag naar deze vakspecialisten stabiel is, omdat de voordelen van het specialisme op moeten wegen tegen de risico's die met een dergelijke specialisatie worden gelopen.

In paragraaf 7.2 worden de perspectieven op de middellange termijn (tot 2002) voor de verschillende opleidingstypen op VBO-, AVO- en MBO/Leerlingwezen-niveau kort samengevat. Het arbeidsmarktperspectief van een bepaalde opleiding geeft aan wat - op basis van de verwachte ontwikkelingen aan de vraag- en aanbodzijde van de arbeidsmarkt over vijf jaar - de mogelijkheden zijn voor nieuwkomers om een baan te vinden die op grond van de opleidingsachtergrond als passend kan worden beschouwd. Een onzekere factor hierbij is de verwachte economische ontwikkeling. Daarom wordt in paragraaf 7.3 aandacht geschonken aan de conjunctuurgevoeligheid van de werkgelegenheid voor de verschillende opleidingstypen. Een verslechtering van het arbeidsmarktperspectief vermindert de kansen op een passende baan, maar hoeft niet te betekenen dat de kansen op werk in gelijke mate verslechteren. In paragraaf 7.4 wordt aangegeven in hoeverre de schoolverlaters van een bepaalde opleiding uitwijkmogelijkheden naar andere beroepsgroepen hebben, wanneer de vraag voor een bepaalde beroepsgroep stagneert. In paragraaf 7.5 wordt een typologie gegeven van de arbeidsmarktkansen voor de schoolverlaters van de onderscheiden opleidingstypen op VBO- en MBO/Leerlingwezen-niveau op de Limburgse arbeidsmarkt aan de hand van het toekomstig arbeidsmarktperspectief, de conjunctuurgevoeligheid van de werkgelegenheid en de uitwijkmogelijkheden op de arbeidsmarkt ${ }^{84}$. Dit hoofdstuk wordt in paragraaf 7.6 afgesloten met een aantal aandachtspunten voor het onderwijsbeleid.

84. Vooralsnog zijn, in het licht van de betrouwbaarheid en de beschikbaarheid van de vereiste regionale data, de indicatoren voor de conjunctuurgevoeligheid van de werkgelegenheid en de uitwijkmogelijkheden gebaseerd op landelijke cijfers. 


\subsection{Het toekomstig arbeidsmarktperspectief ${ }^{35}$}

Aan de hand van de verwachte ontwikkelingen aan de vraagzijde van de arbeidsmarkt - de openstaande vacatures aan het begin van de prognoseperiode en de verwachte baanopeningen in de komende jaren - en de aanbodzijde - de direct inzetbare werkzoekenden aan het begin van de prognoseperiode en de schoolverlaters die de komende jaren op de arbeidsmarkt zullen instromen - is in hoofdstuk 4 een indicatie gegeven van de te verwachten toekomstige arbeidsmarktperspectieven voor nieuwkomers op de arbeidsmarkt, verbijzonderd naar opleidingstype. Kort samengevat leidde dit tot de volgende conclusies.

\section{Opleidingen met zeer goede perspectieven}

De voor de periode 1997-2002 verwachte relatief gunstige arbeidsmarktontwikkelingen in Limburg zullen ertoe leiden dat voor een groot aantal opleidingstypen goede tot zeer goede arbeidsmarktperspectieven worden verwacht. Op de Limburgse arbeidsmarkt zullen de aanbodtekorten naar verwachting sterker merkbaar zijn dan landelijk, waardoor de perspectieven voor de Limburgse nieuwkomers gemiddeld genomen beter zijn dan voor de nieuwkomers in de rest van het land. Dit verschil met het landelijke beeld valt met name toe te schrijven aan demografische factoren. Met name de vervangingsvraag zal naar verwachting in Limburg aanzienlijk hoger zijn dan landelijk, als gevolg van de snelle vergrijzing van de Limburgse beroepsbevolking. In tabel 7.1 wordt een overzicht gegeven van de opleidingstypen waarvoor een zeer goed arbeidsmarktperspectief in 2002 wordt voorspeld. Dit blijken uitsluitend opleidingen op MBO/Leerlingwezen-niveau te zijn. De opleidingen verpleging en bouw worden daarbij gekenmerkt door een relatief grote omvang van de markt. De opleidingen milieu en groene ruimte en geld, bank en belastingen zijn daarentegen relatief klein. In tabel 6.8 van de Statistische Bijlage worden ook de opleidingstypen genoemd waarvan de arbeidsmarktperspectieven naar verwachting 'goed' zijn.

85. Zie voor meer details hoofdstuk 4 van dit rapport. 
Tabel 7.1

Opleidingstypen met zeer goede arbeidsmarktperspectieven in Limburg in 2002

Opleidingstype

ITA

typering

aantal

werkenden

MBO/LLW vervoer

0,73

zeer goed

3.000

$\mathrm{MBO} / \mathrm{LLW}$ procestechniek

0,74

zeer goed

4.000

MBO/LLW bedrijfskunde

0,76

zeer goed

2.500

$\mathrm{MBO} / \mathrm{LLW}$ verpleging

0,79

zeer goed

9.000

MBO/LLW bouw

0,80

zeer goed

8.000

$\mathrm{MBO} / \mathrm{LLW}$ motorvoertuigentechniek

0,81

zeer goed

5.000

$\mathrm{MBO} / \mathrm{LLW}$ automatisering

0,82

zeer goed

3.000

MBO/LLW horeca

0,85

zeer goed

MBO/LLW geld, bank en belastingen

0,85

zeer goed

6.500

Bron: ROA

Opleidingen met een redelijk tot slecht perspectief

Ondanks de toenemende krapte op de Limburgse arbeidsmarkt is er, met name op VBOniveau, een aantal opleidingen waarvoor de arbeidsmarktperspectieven in 2002 redelijk tot slecht zijn. In tabel 7.2 wordt van deze opleidingen een overzicht gegeven ${ }^{86}$.

Tabel 7.2

Opleidingstypen met redelijk tot slechte arbeidsmarktperspectieven in Limburg in 2002

Opleidingstype

ITA

typering

aantal

werkenden

VBO administratie, handel en textiel

Basisonderwijs

1,28

1,14

slecht

8.500

VBO landbouw en natuurlijke omgeving

1,12

matig

38.000

HAVONWO

1,09

matig

5.000

VBO horeca en levensmiddelentechniek

matig

19.500

VBO verzorging

1,05

matig

2.500

VBO motorvoertuigentechniek

1,04

redelijk

17.000

MAVO

1,02

redelijk

3.500

MBO sociaal-cultureel

1,00

redelijk

30.500

1,00

redelijk

3.500

Bron: ROA

Uit de tabellen 7.1 en 7.2 komt een opmerkelijk contrast naar voren in de arbeidsmarktperspectieven van de opleiding motorvoertuigentechniek op VBO- en

86. Drie opleidingstypen waarvoor de arbeidsmarktperspectieven voor nieuwkomers matig zijn, zijn niet in tabel 7.2 opgenomen, vanwege het geringe aantal werkenden met deze opleidingsachtergrond in Limburg. Dit zijn de opleidingen VBO grafische techniek en de $\mathrm{MBO} /$ Leerlingwezen-opleidingstypen beweging en therapie en toerisme en recreatie. 
$\mathrm{MBO} /$ Leerlingwezen-niveau. In mindere mate geldt dit ook voor de horeca-opleidingen. Voor degenen met alleen een VBO-opleiding zijn de arbeidsmarktperspectieven ongunstig, terwijl er aan de andere kant tekorten zijn aan arbeidskrachten met eenzelfde opleidingsrichting op MBO/Leerlingwezen-niveau. Dit geeft ook duidelijk de spanning weer tussen de gevraagde kwalificaties en de kwalificaties van het werkzoekende arbeidsaanbod. Met name voor de genoemde opleidingsrichtingen is het dus van groot belang om de schoolverlaters van het VBO door te laten leren totdat zij een zogenaamde startkwalificatie voor de arbeidsmarkt behalen.

Overigens kan voor de overige VBO-opleidingen hetzelfde worden gezegd. Bij sommige opleidingen zijn de arbeidsmarktperspectieven voor VBO'ers weliswaar niet ongunstig, maar dit is voor een belangrijk deel het gevolg van de vervangingsvraag vanwege de hoge arbeidsmarktuitstroom van laag geschoolden op relatief jonge leeftijd. Alleen door alsnog een startkwalificatie op MBO/Leerlingwezen-niveau te behalen kunnen schoolverlaters voorkomen zelf in een dergelijke fuik van 'dead end jobs' terecht te komen. Met andere woorden: de macrodoelmatigheid van het beroepsonderwijs is sterk gebaat bij een optimaal aanbod van leerwegen die het voor VBO'ers mogelijk maken een startkwalificatie op de arbeidsmarkt te behalen. Aangenomen mag worden dat degenen die daar de meeste moeite mee hebben, het meest gebaat zijn bij beroepsbegeleidende leerwegen die het meest aansluiten bij de meer praktische oriëntatie van veel van deze schoolverlaters.

\subsection{De conjunctuurgevoeligheid}

Het arbeidsmarktperspectief wordt voor een belangrijk deel bepaald door de verwachte economische ontwikkeling. Een goed perspectief kan het gevolg zijn van een structureel sterke positie van het betreffende opleidingstype op de arbeidsmarkt. Het kan echter ook voor een belangrijk deel conjunctureel van aard zijn. De relatief gunstige conjuncturele ontwikkeling kan dan een structureel zwakke positie tijdelijk compenseren. Wanneer de keuze voor een conjunctuurgevoelig opleidingstype gebaseerd is op een goed perspectief, bestaat het risico dat de kansen op de arbeidsmarkt op het moment dat het diploma behaald wordt slecht zijn, omdat de economische situatie door een conjuncturele dip plotseling is verslechterd. Bovendien is er in dat geval sprake van een onzekere werkgelegenheidssituatie op langere termijn, vanwege de grotere kans op toekomstig baanverlies als er op een gegeven moment sprake is van een laagconjunctuur. De conjunctuurgevoeligheid van de werkgelegenheid is derhalve een risico-indicator, waarmee een belangrijk facet wordt belicht van de structurele arbeidsmarktpositie van de verschillende opleidingstypen.

Om een beter beeld te krijgen van de mogelijke kwetsbaarheid van de verschillende opleidingstypen voor conjuncturele schommelingen in de werkgelegenheid, wordt in deze paragraaf ingegaan op de conjunctuurgevoeligheid van de werkgelegenheid van de onderscheiden opleidingstypen op VBO- en MBO/Leerlingwezen-niveau. 
In tabel 7.3 wordt een overzicht gegeven van de opleidingstypen waarvoor de conjunctuurgevoeligheid van de werkgelegenheid relatief het grootst is. Uit de tabel blijkt dat met name opleidingstypen die voor een belangrijk deel afhankelijk zijn van de werkgelegenheid in de conjunctuurgevoelige bouwsector gekenmerkt worden door grote schommelingen in de werkgelegenheid. Dit geldt zowel voor de opleidingen op VBO- als op $\mathrm{MBO} /$ Leerlingwezen-niveau. Ook de vervoersopleidingen worden gekenmerkt door een hoge conjunctuurgevoeligheid. Dit betekent niet alleen dat de arbeidsmarktkansen voor nieuwkomers met deze opleidingsachtergrond onderhevig zijn aan conjuncturele fluctuaties. Bij deze opleidingen is ook het risico om de baan te verliezen wanneer de conjunctuur verslechtert, relatief groot.

Tabel 7.3

Opleidingstypen met de grootste conjunctuurgevoeligheid

Opleidingstype conjunctur- typering

erg hoog

erg hoog

erg hoog

erg hoog

erg hoog

erg hoog

erg hoog

hoog

Bron: ROA

Opleidingstypen met een lage conjunctuurgevoeligheid

In tabel 7.4 wordt een overzicht gegeven van de opleidingstypen waarvoor de conjunctuurgevoeligheid van de werkgelegenheid relatief het geringst is. Uit de tabel blijkt dat met name de werkgelegenheid voor middelbaar opgeleiden relatief ongevoelig is voor conjuncturele fluctuaties. Ook op dit punt blijkt weer de kwetsbaarheid van de werkenden die slechts een opleiding op VBO-niveau hebben. Bovendien blijkt uit de tabel dat vooral medische en 'groene' opleidingen gekenmerkt worden door een lage conjunctuurgevoeligheid. Een lage conjunctuurgevoeligheid betekent niet alleen dat het arbeidsmarktperspectief voor nieuwkomers relatief ongevoelig is voor conjuncturele fluctuaties. Zoals gezegd, is ook de kans om de baan te verliezen bij een economische neergang relatief klein. 
Tabel 7.4

Opleidingstypen met de kleinste conjunctuurgevoeligheid

Opleidingstype conjunctur- typering

gevoeligheid

$\begin{array}{lll}\text { MBO/LLW brood en banket } & 0,40 & \text { laag } \\ \text { MBO/LLW apothekersassistent } & 0,43 & \text { laag } \\ \text { MBO/LLW gezondheidstechniek } & 0,43 & \text { laag } \\ \text { MBO/LLW milieu en groene ruimte } & 0,45 & \text { laag } \\ \text { MBO/LLW landbouw en veeteelt } & 0,51 & \text { laag } \\ \text { MBO/LLW laboratorium } & 0,51 & \text { laag } \\ \text { MBO openbare orde en veiligheid } & 0,55 & \text { laag } \\ \text { MBO dokters-, tandarts- en dierenartsassistent } & 0,59 & \text { laag }\end{array}$

Bron: ROA

\subsection{De uitwijkmogelijkheden}

De risico's op de arbeidsmarkt beperken zich niet tot de conjuncturele fluctuaties in de werkgelegenheid. Ook de mate waarin schoolverlaters afhankelijk zijn van de werkgelegenheidsperspectieven in een beperkt aantal beroepsgroepen is een belangrijke risicofactor. Dit risico is vooral groot bij opleidingen die specifiek gericht zijn op functies in een bepaalde vakdeelmarkt. Degenen die daarentegen een opleiding hebben gevolgd waarmee men in diverse beroepsgroepen emplooi kan vinden, kunnen, wanneer het werkgelegenheidsperspectief in een bepaalde beroepsgroep minder gunstig is, betrekkelijk gemakkelijk uitwijken naar beroepen waarvoor de werkgelegenheidsontwikkeling gunstiger is. $\mathrm{Er}$ is als het ware sprake van een zekere risico-spreiding. Bovendien zijn degenen die voor deze opleidingen hebben gekozen ook meer flexibel op de arbeidsmarkt doordat men tijdens de studie- of arbeidsloopbaan meer inzicht verkrijgt in de persoonlijke capaciteiten en voorkeuren die men heeft, waardoor de beroepsperspectieven die aanvankelijk aantrekkelijk leken hun aantrekkingskracht verliezen. In dat geval mag verwacht worden dat men minder snel voortijdig de opleiding zal verlaten, dan wanneer een opleiding gevolgd wordt die specifiek voor een bepaald beroep opleidt.

Het volgen van een brede opleiding is overigens niet in alle gevallen positief. Wanneer er sprake is van veel uitwijkmogelijkheden impliceert dit immers ook dat de schoolverlaters meer concurrentie ondervinden van andere opleidingstypen. Bovendien kan een verbreding van de opleiding ten koste gaan van de specialisatie, waardoor de productiviteit, c.q. de directe inzetbaarheid van de schoolverlaters geringer wordt. Wanneer de concurrentieslag met andere opleidingen daardoor verloren wordt, kan dat betekenen dat de schoolverlaters in een breed scala van onaantrekkelijke beroepen met slechte arbeidsvoorwaarden terechtkomen (de zogenaamde secundaire arbeidsmarkt). 
In tabel 7.5 wordt een overzicht gegeven van de opleidingstypen met de grootste uitwijkmogelijkheden. Grofweg bevat de tabel drie categorieën opleidingen. In de eerste plaats, niet verrassend, de algemene opleidingen Basisonderwijs, MAVO en HAVO/VWO. Werkenden met een algemene opleidingsachtergrond zijn werkzaam in een zeer breed scala van beroepen waarvoor een laag kwalificatieniveau vereist is (bijvoorbeeld productiemedewerkers) of de nadruk ligt op algemene vaardigheden (bijvoorbeeld commercieel employés). In dit geval is het cruciaal dat door middel van additionele cursussen of trainingen het vereiste opleidingsniveau bereikt wordt. In het algemeen zijn deze opleidingen een duidelijk voorbeeld van de opleidingen met een relatief geringe directe inzetbaarheid van schoolverlaters in een bepaalde vakdeelmarkt. De grote uitwijkmogelijkheden wijzen derhalve niet op een structureel sterke arbeidsmarktpositie, maar geven aan dat de werkenden met deze opleidingsachtergrond zijn aangewezen op een breed scala aan relatief onaantrekkelijke functies met slechte lange-termijn perspectieven.

De tweede categorie betreft de VBO-opleidingen fijnmechanische techniek en elektrotechniek. De schoolverlaters van deze opleidingen komen in een breed scala van monteursberoepen terecht. Het opleidingstype VBO administratie, handel en textiel vormt de derde categorie. Ook de werkenden met deze opleidingsachtergrond komen in een breed scala van onaantrekkelijke banen terecht. Het is een typisch voorbeeld van een opleiding die de concurrentieslag verliest en waarvan de schoolverlaters voor een groot deel op de secundaire arbeidsmarkt terecht, waardoor hun arbeidsmarktpositie relatief sterk is.

De laatste categorie wordt gevormd door de MBO/Leerlingwezen-opleidingen bedrijfskunde en handel. Bij deze opleidingstypen is er sprake van een sterke arbeidsmarktpositie vanwege de brede inzetbaarheid op de arbeidsmarkt.

Tabel 7.5

Opleidingstypen met de grootste uitwijkmogelijkheden naar verschillende beroepsgroepen, gemiddelde 1995-1996

Opleidingstype

spreidings- $\quad$ typering

index

MBO/LLW bedrijfskunde

Basisonderwijs

MAVO

HAVONWO

VBO fijnmechanische techniek

VBO administratie, handel en textiel

MBO/LLW handel

VBO elektrotechniek

$\begin{array}{ll}21,32 & \text { erg hoog } \\ 20,56 & \text { erg hoog } \\ 19,08 & \text { erg hoog } \\ 16,78 & \text { hoog } \\ 15,24 & \text { hoog } \\ 14,42 & \text { hoog } \\ 12,86 & \text { hoog } \\ 12,67 & \text { hoog }\end{array}$

Bron: ROA

In tabel 7.6 is een overzicht gegeven van de opleidingstypen op MBO/Leerlingwezen-niveau 
die gekenmerkt worden door grote uitwijkmogelijkheden op de arbeidsmarkt. Gezien het wat hogere niveau van de opleidingen, mag op MBO/Leerlingwezen-niveau een hoge beroepenspreiding daadwerkelijk als een indicatie voor een brede inzetbaarheid beschouwd worden. De tabel laat een breed scala aan opleidingstypen zien met een relatief brede inzetbaarheid op de arbeidsmarkt. In termen van de employability van de werkenden nemen deze opleidingstypen derhalve een relatief sterke positie $i^{87}$.

\section{Tabel 7.6}

Opleidingstypen op $\mathrm{MBO} /$ Leerlingwezen-niveau met de grootste uitwijkmogelijkheden naar verschillende beroepsgroepen, gemiddelde 1995-1996

$\begin{array}{lrl}\text { MBO/LLW bedrijfskunde } & 21,32 & \text { erg hoog } \\ \text { MBO/LLW handel } & 12,86 & \text { hoog } \\ \text { MBO/LLW vervoer } & 11,03 & \text { hoog } \\ \text { MBO sociaal-cultureel } & 9,58 & \text { gemiddeld } \\ \text { MBO/LLW fijnmechanische techniek } & 9,52 & \text { gemiddeld } \\ \text { MBO/LLW beweging en therapie } & 9,34 & \text { gemiddeld } \\ \text { MBO/LLW werktuigbouwtechniek en mechanische techniek } & 9,05 & \text { gemiddeld } \\ \text { MBO/LLW horeca } & 7,95 & \text { gemiddeld }\end{array}$

\section{Bron: ROA}

Tabel 7.7

Opleidingstypen met de kleinste uitwijkmogelijkheden naar verschillende beroepsgroepen, gemiddelde 1995-1996

MBO/LLW apothekersassistent

$\mathrm{MBO} / \mathrm{LLW}$ gezondheidstechniek

VBO vervoer

MBO/LLW installatietechniek

MBO dokters-, tandarts- en dierenartsassistent

$M B O$ verzekeringswezen

$\mathrm{MBO} / \mathrm{LLW}$ verpleging

MBO/LLW uiterlijke verzorging

$\begin{array}{ll}1,67 & \text { erg laag } \\ 1,83 & \text { erg laag } \\ 2,17 & \text { erg laag } \\ 2,37 & \text { erg laag } \\ 2,55 & \text { erg laag } \\ 2,71 & \text { erg laag } \\ 3,17 & \text { erg laag } \\ 3,41 & \text { erg laag }\end{array}$

Bron: ROA

87. Overigens is de employability van de werkenden met deze opleidingsachtergrond vanzelfsprekend ook sterk afhankelijk van de mate waarin er kwalificatieveroudering optreedt vanwege technologische en organisatorische ontwikkelingen. 
In tabel 7.7 wordt een overzicht gegeven van de opleidingstypen met de geringste beroepenspreiding, hetgeen een indicatie vormt voor het specifieke karakter van een opleiding, gericht op bepaalde functies in een specifieke vakdeelmarkt. De medische en verzorgende opleidingstypen op MBO/Leerlingwezen-niveau zijn duidelijk oververtegenwoordigd in deze tabel. Het opleidingstype met de geringste beroepenspreiding is de opleiding MBO/LLW apothekersassistent. Meer dan driekwart van de werkenden met deze opleidingsachtergrond is werkzaam als apothekersassistent of medisch laborant. VBO vervoer is het enige opleidingstype op VBO-niveau in de tabel. Arbeidskrachten met deze opleidingsachtergrond zijn voornamelijk werkzaam als chauffeur.

\subsection{Kansen op de arbeidsmarkt: een typologie}

Terwijl het toekomstig arbeidsmarktperspectief een indicatie geeft van de kansen voor nieuwkomers op de arbeidsmarkt op een passende baan gezien hun opleidingsachtergrond, geven de conjunctuurgevoeligheid en de uitwijkmogelijkheden aan in hoeverre de keuze voor een opleiding gepaard gaat met een arbeidsmarktrisico dat de arbeidsmarktkansen zou kunnen ondermijnen ${ }^{88}$.

Wanneer een goed arbeidsmarktperspectief gepaard gaat met een laag arbeidsmarktrisico dat wil zeggen een lage tot gemiddelde conjunctuurgevoeligheid van de werkgelegenheid en gemiddelde tot grote uitwijkmogelijkheden - dan geeft het betreffende opleidingstype schoolverlaters een structureel sterke positie op de arbeidsmarkt. Op de Limburgse arbeidsmarkt geldt dit met name voor de volgende opleidingstypen:

- MBO/LLW landbouw en veeteelt;

- MBO/LLW milieu en groene ruimte;

- MBO/LLW brood en banket;

- MBO/LLW levensmiddelentechniek/vleesverwerking;

- MBO/LLW horeca;

- MBO/LLW administratie;

- MBO/LLW handel;

- MBO/LLW bedrijfskunde;

- MBO/LLW geld, bank en belastingen;

- MBO/LLW automatisering.

Deze opleidingstypen zijn grofweg te verdelen in twee groepen. Bij de eerste groep bestaande uit de 'groene' opleidingen landbouw en veeteelt en milieu en groene ruimte en de op de voedingsmiddelbranche gerichte opleidingen brood en banket en levensmiddelentechniek gaat het goede perspectief met name gepaard met een lage

88. Een volledig overzicht van het arbeidsmarktperspectief, de conjunctuurgevoeligheid en de uitwijkmogelijkheden naar opleidingstype, waarop deze paragraaf is gebaseerd, wordt in de tabellen 6.8 en 6.9 van de Statistische Bijlage gegeven. 
conjunctuurgevoeligheid $^{89}$. De kansen op werk voor nieuwkomers zijn relatief ongevoelig voor conjuncturele fluctuaties. Bovendien zal, wanneer de conjunctuur verslechtert, de kans relatief klein zijn dat men zijn baan verliest. De tweede groep wordt gevormd door de economische opleidingen administratie, handel, automatisering en geld, bank en belastingen. Deze opleidingstypen worden naast de goede arbeidsmarktperspectieven op middellange termijn gekenmerkt door een brede inzetbaarheid op de arbeidsmarkt.

Wanneer daarentegen een goed arbeidsmarktperspectief gepaard gaat met een hoog risico - een gemiddeld tot (erg) hoge conjunctuurgevoeligheid en gemiddelde tot (erg) lage uitwijkmogelijkheden - dan is weliswaar, op grond van de verwachte arbeidsmarktontwikkelingen, de kans op een passende baan voor de schoolverlaters met een dergelijke opleidingsachtergrond groot, maar kan een verslechtering van de arbeidsmarktsituatie een sterk negatief effect hebben op de arbeidsmarktpositie. Dit geldt met name voor de volgende opleidingstypen:

- VBO bouwtechniek;

- VBO installatietechniek;

- VBO fijnmechanische techniek;

- VBO elektrotechniek;

- VBO brood en banket;

- VBO vervoer;

- VBO beveiliging;

- alle technische opleidingen op MBO/Leerlingwezen-niveau, met uitzondering van de op de voedingsmiddelbranche gerichte opleidingen brood en banket en levensmiddelentechnologie;

- MBO/LLW secretariaat;

- MBO verzekeringswezen;

- MBO openbare orde en veiligheid.

Deze categorie bestaat derhalve voor een groot deel uit technische opleidingen. De arbeidsmarktkansen voor de schoolverlaters van de technische opleidingen worden voor een aanzienlijk deel bepaald door de werkgelegenheidsontwikkelingen in de conjunctuurgevoelige industriële bedrijfssectoren en de bouw. Het goede arbeidsmarktperspectief is dus voor een deel conjunctureel van aard. Een (onvoorziene) conjuncturele verslechtering kan het perspectief aanzienlijk verslechteren. Ook het arbeidsmarktrisico voor de MBOopleidingen secretariaat en verzekeringswezen en de beveiligingsopleidingen is relatief groot. Voor deze opleidingstypen vormt met name de beperkte inzetbaarheid buiten het eigen beroependomein een risicoverhogende factor.

Een bijzondere positie nemen de verzorgende en medische opleidingen op $\mathrm{MBO} /$ Leerlingwezen-niveau in. Het arbeidsmarktperspectief voor deze opleidingstypen is goed tot zeer goed. Bovendien is de conjunctuurgevoeligheid van de werkgelegenheid laag. Twee factoren maken de arbeidsmarktpositie van de schoolverlaters van deze

89. Opgemerkt dient te worden dat hierbij geen rekening is gehouden met de gevolgen van de varkenspest. 
opleidingstypen echter kwetsbaar. In de eerste plaats is de omvang van de vraag in aanzienlijke mate afhankelijk van het overheidsbeleid. In de tweede plaats zijn de arbeidskrachten met een medische of verzorgende opleidingsachtergrond beperkt inzetbaar; de uitwijkmogelijkheden op de arbeidsmarkt zijn over het algemeen gering.

Wanneer een slecht arbeidsmarktperspectief gepaard gaat met een gering arbeidsmarktrisico, dan is de kans op een passende baan naar verwachting weliswaar klein, maar biedt de brede inzetbaarheid misschien mogelijkheden elders op de arbeidsmarkt een plek te vinden. Dit geldt met name voor de volgende opleidingstypen:

- MAVO;

- VBO horeca en levensmiddelentechniek;

- VBO administratie, handel en textiel;

- VBO verzorging;

- HAVONWO;

- MBO sociaal-cultureel.

Gezien het lage opleidingsniveau is deze brede inzetbaarheid voor de MAVO'ers en de genoemde VBO-opleidingen, zoals reeds eerder werd aangegeven, een betrekkelijk begrip. Vaak zullen schoolverlaters terechtkomen in functies op de 'secundaire arbeidsmarkt'. Dit secundaire arbeidsmarktsegment kent met name banen die een onaantrekkelijk karakter hebben als gevolg van bijvoorbeeld zware arbeidsomstandigheden en tijdelijke contracten.

Opleidingstypen waarvoor het arbeidsmarktperspectief naar verwachting slecht zal zijn en waarvoor bovendien de risico-indicatoren wijzen op een grote kwetsbaarheid, kennen een structureel zwakke positie op de arbeidsmarkt. De kans op een passende baan is klein en bovendien is de concurrentiepositie op andere segmenten van de arbeidsmarkt zo zwak dat er nauwelijks alternatieve banen te vinden zijn. Dit geldt voor de volgende opleidingstypen:

- VBO vervoer;

- VBO motorvoertuigentechniek;

- VBO grafische techniek;

- MBO/LLW toerisme en recreatie.

Met name de hoge conjunctuurgevoeligheid maakt de VBO-opleidingen bouwtechniek, motorvoertuigentechniek en grafische techniek extra kwetsbaar. Schoolverlaters van de opleiding MBO/LLW toerisme en recreatie zijn binnen het MBO de kwetsbare groep vanwege de slechte arbeidsmarktperspectieven en de beperkte inzetbaarheid op de arbeidsmarkt.

\subsection{Aandachtspunten voor het onderwijsbeleid}

Vanuit het oogpunt van de zogenaamde macrodoelmatigheid van het onderwijs is het wenselijk de instroom van leerlingen in opleidingen met goede of zeer goede arbeidsmarktperspectieven te bevorderen. Het zonder meer vergroten van het onderwijsaanbod zal echter niet altijd de gewenste effecten sorteren. Een vergroting van de opleidingscapaciteit garandeert immers niet dat deze capaciteit ook benut zal worden. Een verruimde geografische spreiding of de introductie van een opleidingsvariant die op dat 
moment nog niet wordt aangeboden, zal doorgaans wel de leerlingeninstroom voor het betreffende opleidingstype verhogen, doordat mobiliteitsdrempels worden weggenomen of beter ingespeeld kan worden op de interesse of capaciteiten van leerlingen.

Een vraag die zich voordoet bij een dergelijke uitbreiding van het onderwijsaanbod is echter welke leerlingen hiermee worden aangetrokken. Als een verhoogde geografische spreiding er alleen toe leidt dat leerlingen dezelfde opleiding minder ver van huis kunnen volgen, of als de extra belangstelling voor een nieuwe opleiding met goede perspectieven leerlingen trekt die anders een andere opleiding met zeer goede perspectieven hadden gekozen, is de macrodoelmatigheid van de nieuwe opleiding ondanks de gunstige arbeidsmarktperspectieven beperkt. Nieuw aanbod van opleidingen zal daarom met name baat hebben wanneer er leerlingen worden aangetrokken die anders een opleiding zouden kiezen met duidelijk slechtere perspectieven.

Naast het arbeidsmarktperspectief, dat gebaseerd is op de verwachte ontwikkelingen in vraag en aanbod, kan het onderwijsbeleid ook de structurele positie van opleidingen als richtlijn nemen. Een tweetal risico-indicatoren is op dit punt van belang: de conjunctuurgevoeligheid van de werkgelegenheid en de uitwijkmogelijkheden naar andere beroepsgroepen. Zo zijn er bepaalde opleidingen die een hoge mate van conjunctuurgevoeligheid combineren met beperkte uitwijkmogelijkheden. Veranderingen in het onderwijs, waardoor de opleiding wordt verbreed en daardoor toegang verschaft tot een breder beroependomein, kunnen deze kwetsbaarheid verminderen. Omgekeerd kunnen ontwikkelingen aan de vraagkant van de arbeidsmarkt leiden tot een behoefte aan personeel met zeer specifieke vaardigheden. Hierdoor kan het wenselijk zijn een meer specialistische opleiding te starten. Hierbij dient altijd wel overwogen te worden in hoeverre de vraag naar deze vakspecialisten stabiel is, omdat de voordelen van het specialisme op moeten wegen tegen de arbeidsmarktrisico's die een dergelijke specialisatie met zich meebrengt.

De volgende opleidingstypen hebben een structureel sterke positie op de Limburgse arbeidsmarkt: MBO/LLW landbouw en veeteelt; MBO/LLW milieu en groene ruimte; MBO/LLW brood en banket; MBO/LLW levensmiddelentechniek; MBO/LLW horeca; MBO/LLW administratie; MBO/LLW handel; MBO/LLW bedrijfskunde, MBO/LLW geld, bank en belastingen en MBO/LLW automatisering. Met name voor een aantal opleidingen gericht op de industriële sectoren en de bouwsector is het perspectief goed, maar is de positie kwetsbaar als gevolg van de hoge conjunctuurgevoeligheid.

Een bijzondere positie nemen de verzorgende en medische opleidingen op $\mathrm{MBO} /$ Leerlingwezen-niveau in. Het arbeidsmarktperspectief voor deze opleidingstypen is goed tot zeer goed. Bovendien is de conjunctuurgevoeligheid van de werkgelegenheid laag. Twee factoren maken de arbeidsmarktpositie van de schoolverlaters van deze opleidingstypen echter kwetsbaar. In de eerste plaats is de omvang van de vraag in aanzienlijke mate afhankelijk van het overheidsbeleid. In de tweede plaats zijn de arbeidskrachten met een medische of verzorgende opleidingsachtergrond beperkt inzetbaar; de uitwijkmogelijkheden op de arbeidsmarkt zijn over het algemeen gering. 
De opleidingstypen MAVO; VBO horeca en levensmiddelentechniek; VBO administratie, handel en textiel; VBO verzorging; HAVO/NWO en MBO sociaal-cultureel kennen een slecht perspectief. De brede inzetbaarheid biedt echter misschien mogelijkheden elders op de arbeidsmarkt een plek te vinden. Vaak zal men dan terecht komen op de secundaire arbeidsmarkt. Een structureel zwakke positie op de arbeidsmarkt hebben de opleidingstypen VBO vervoer; VBO motorvoertuigentechniek; VBO grafische techniek en MBO/LLW toerisme en recreatie.

De macrodoelmatigheid van het beroepsonderwijs is al met al het meest gebaat bij een adequaat aanbod van leerwegen die VBO schoolverlaters in staat stellen een kwalificatie op MBO/Leerlingwezen-niveau te behalen. Dit geldt het sterkst voor de vervoers-, motorvoertuigentechniek, grafische techniek-, administratie, handel en horeca-opleidingen. Vanzelfsprekend geldt dit ook voor de opleidingen die ongeschoolden met slechts Basisonderwijs, MAVO'ers en HAVO-VWO'ers in staat stellen met succes een beroepsopleiding te volgen met goede arbeidsmarktperspectieven en geringe arbeidsmarktrisico's. Ook opleidingen die een verschuiving van de schoolkeuze van het te populaire opleidingstype MBO/LLW toerisme en recreatie naar administratief-economische opleidingen met een betere arbeidsmarktpositie bewerkstelligen, kunnen een belangrijke bijdrage leveren aan het vergroten van de macrodoelmatigheid van het onderwijs in Limburg. 


\section{Verklarende woordenlijst}

\section{Arbeidsmarktkrapte}

Het begrip arbeidsmarktkrapte dat in deze rapportage gehanteerd wordt, is gedefinieerd als de verhouding tussen het aantal openstaande vacatures en het aantal werkzoekenden in bemiddelingsfase 1 naar beroepsklasse of opleidingstype. Wanneer de indicator voor de arbeidsmarktkrapte kleiner is dan één, is er sprake van een aanbodoverschot op het betreffende arbeidsmarktsegment. Wanneer de indicator voor de arbeidsmarktkrapte groter is dan één, is er sprake van een tekort aan werkzoekenden in het betreffende segment. Dit tekort kan twee oorzaken hebben: wanneer het aanbod getalsmatig tekortschiet is er sprake van een kwantitatief probleem. De knelpuntsindicator (zie hier beneden) zal dan groter zijn dan één. Wanneer het probleem vooral gelegen is in het feit dat het percentage werkzoekenden in fase 1 laag is, is dit tekort vooral een kwalitatief aansluitingsprobleem dat zich zal manifesteren in een knelpuntsindicator kleiner dan één. Aangezien werkzoekenden niet naar bedrijfssector ingedeeld kunnen worden, kan deze maatstaf niet gebruikt worden om de arbeidsmarktkrapte naar bedrijfssector te berekenen. De arbeidsmarktkrapte naar bedrijfssector is daarom gedefinieerd als het gewogen gemiddelde van de arbeidsmarktkrapte naar beroepsgroep. De wegingsfactor is daarbij gebaseerd op het aandeel van de betreffende beroepsgroep in het totale aantal vacatures in die bedrijfssector. Hoe hoger de arbeidsmarktkrapte in een bedrijfssector, hoe groter de rekruteringsproblemen.

\section{Baanopeningen}

De totale vraag naar nieuwkomers op de arbeidsmarkt, zoals deze is bepaald door de werkgelegenheidsgroei (positieve uitbreidingsvraag) en de vervangingsvraag.

\section{Bedrijfsklasse}

Alle voorkomende bedrijven zijn ingedeeld in een aantal clusters. De totale werkgelegenheidscijfers zijn in deze rapportage verbijzonderd naar 33 bedrijfsklassen.

\section{Bedrijfssector}

Alle voorkomende bedrijven zijn ingedeeld in een aantal clusters. De in deze rapportage gepresenteerde informatie is - met uitzondering van de totale werkgelegenheid verbijzonderd naar 13 bedrijfssectoren. Deze komen overeen met de door het CPB gehanteerde bedrijfssectorindeling.

\section{Bemiddelingsfase}

Het begrip bemiddelingsfase dat in deze rapportage wordt gehanteerd, is gebaseerd op de indeling zoals dat door Arbeidsvoorziening in het Primair Gemeenschappelijk Informatiesysteem wordt gehanteerd. Arbeidsvoorziening classificeert hierbij de werkzoekenden naar bemiddelbaarheid; wanneer de kwalificatie 'fase 1' aan een werkzoekende wordt toegekend, is deze in principe direct bemiddelbaar. Wanneer een 
werkzoekende in een hogere bemiddelingsfase wordt ingedeeld, impliceert dit een grotere afstand tot de arbeidsmarkt.

\section{Beroepsgroep}

Alle voorkomende beroepen zijn ingedeeld in een aantal clusters. In deze rapportage wordt hoofdzakelijk uitgegaan van 127 beroepsklassen, gebaseerd op de SBC van het CBS.

\section{Beroepssector}

Alle voorkomende beroepen zijn ingedeeld in een aantal clusters. Zo worden in hoofdstuk 1 tien beroepssectoren onderscheiden.

\section{Bijscholing}

Er is sprake van bijscholing wanneer een scholingstraject de opleidingsachtergrond van een werkzoekende niet verandert.

\section{Bijscholingspotentieel in verhouding tot de scholingsbehoefte}

Het bijscholingspotentieel (in kwantitatieve zin) wordt gevormd door de niet-werkende werkzoekenden in fase 2 en 3 . Het bijscholingspotentieel in verhouding tot de scholingsbehoefte - het verschil tussen de som van de openstaande vacatures en de verwachte baanopeningen enerzijds en de direct inzetbare werkzoekenden (de schoolverlaters en de niet-werkende werkzoekenden in fase 1) anderzijds - geeft aan in hoeverre werkzoekenden door middel van bijscholing hun arbeidsmarktkansen kunnen vergroten. Hoe groter deze verhouding is, hoe groter de mogelijkheden voor de werkzoekenden zijn. Wanneer de bijscholingsbehoefte gering is, zijn de kansen om via bijscholing de arbeidsmarktkansen te vergroten eveneens gering.

\section{Conjunctuurgevoeligheid}

De conjunctuurgevoeligheid van de werkgelegenheid heeft betrekking op de mate waarin de werkgelegenheid voor mensen met een bepaalde opleidingsachtergrond gevoelig is voor veranderingen van de economische situatie. Deze indicator geeft daarmee de mate van werkzekerheid aan. De conjunctuurgevoeligheid wordt bepaald door de sectorale werkgelegenheidsfluctuaties in het verleden te relateren aan de mate waarin een opleidingstype momenteel in de verschillende bedrijfssectoren is vertegenwoordigd. Hierbij wordt rekening gehouden met het feit dat niet ieder opleidingstype even sterk meefluctueert met de werkgelegenheidsschommelingen van de bedrijfssector.

\section{Flexibel werk}

Van flexibel werk is sprake bij uitzendkrachten, oproepkrachten, invalkrachten, contracten zonder een vast aantal arbeidsuren en indien geen vast dienstverband is overeengekomen.

\section{Jongere}

Een jongere is tussen de 15 en de 29 jaar oud. 


\section{Knelpuntsindicator}

Het begrip knelpuntsindicator dat in deze rapportage wordt gehanteerd is gedefinieerd als de verhouding tussen het aantal vacatures dat niet door werkzoekenden uit bemiddelingsfase 1 vervuld kan worden en het aantal werkzoekenden in bemiddelingsfase 2 en 3 . Hoe hoger de knelpuntsindicator, hoe minder werkzoekenden met een grotere afstand tot de arbeidsmarkt er beschikbaar zijn voor de vacatures die niet door direct bemiddelbare werkzoekenden vervuld kunnen worden. Dit impliceert tevens dat een hoge knelpuntsindicator een werkzoekende in het betreffende segment de mogelijkheid biedt via bijscholing de kansen op een baan te vergroten. Wanneer het aantal werkzoekenden in fase 1 het aantal vacatures overtreft, is de knelpuntsindicator gelijk aan 0 . Er is dan geen sprake van een tekort aan gekwalificeerd aanbod. Het aantal banen schiet juist tekort om alle direct inzetbare werkzoekenden aan werk te helpen.

\section{Langdurig werkzoekende}

Het begrip langdurig werkzoekende dat in deze rapportage wordt gehanteerd, is gedefinieerd als een werkzoekende die langer dan een jaar ingeschreven is bij Arbeidsvoorziening. Opgemerkt dient te worden dat dit niet noodzakelijkerwijs impliceert dat de betreffende werkzoekende tijdens de periode niet gewerkt heeft.

\section{Langdurig openstaande vacature}

Het begrip langdurig openstaande vacature dat in deze rapportage wordt gehanteerd, is gedefinieerd als een vacature die langer dan drie maanden openstaat.

\section{Omscholing}

$\mathrm{Er}$ is sprake van omscholing wanneer het scholingstraject de opleidingsachtergrond van een werkzoekende verandert. Omscholing kan zowel niveauverhogend als richtingveranderend van aard zijn.

\section{Opleidingstype}

Alle voorkomende opleidingen zijn samengevoegd tot een aantal clusters. In deze rapportage wordt uitgegaan van 113 opleidingstypen. In een aantal tabellen wordt echter slechts een indeling naar niveau gehanteerd. Deze indelingen zijn gebaseerd op de oude opleidingsstructuur. In het onderstaande overzicht wordt een relatie gelegd tussen de oude opleidingsstructuur en de bijbehorende benamingen en de nieuwe kwalificatiestructuur zoals die is vastgelegd in de WEB. 


\begin{tabular}{|c|c|c|c|c|}
\hline niveau & $\begin{array}{l}\text { nieuwe } \\
\text { opleidingsaanduiding } \\
\text { alle sectoren } \\
\text { behalve agrarisch }\end{array}$ & $\begin{array}{l}\text { opleidingsaanduiding } \\
\text { in de agrarische } \\
\text { sector }\end{array}$ & $\begin{array}{l}\text { oude } \\
\text { opleidingsaanduiding }\end{array}$ & duur \\
\hline 1 & assistentenopleiding & $\begin{array}{l}\text { assisterend } \\
\text { beroepsbeoefenaar }\end{array}$ & - & 0,5-1 jaar \\
\hline 2 & basisberoepsopleiding & $\begin{array}{l}\text { beginnend } \\
\text { beroepsbeoefenaar }\end{array}$ & $\begin{array}{l}\text { MBO-kort } \\
\text { Leerlingwezen-primair }\end{array}$ & 2-3 jaar \\
\hline 3 & vakopleiding & $\begin{array}{l}\text { zelfstandig } \\
\text { beroepsbeoefenaar }\end{array}$ & $\begin{array}{l}\text { MBO-tussen } \\
\text { MBO-lang } \\
\text { Leerlingwezen-secundair }\end{array}$ & 2-4 jaar \\
\hline 4 & middenkaderopleiding & kaderfunctionaris & $\begin{array}{l}\text { MBO-lang } \\
\text { Leerlingwezen-tertiair }\end{array}$ & 3-4 jaar \\
\hline$\overline{4}$ & specialistenopleiding & $\begin{array}{l}\text { gespecialiseerd } \\
\text { beroepsbeoefenaar }\end{array}$ & $\begin{array}{l}\text { Leerlingwezen-tertiair } \\
\text { - }\end{array}$ & $1-2$ jaar \\
\hline
\end{tabular}

\section{Oudere}

Een oudere is tussen de 50 en de 64 jaar oud.

\section{Scholingsbehoefte}

Wanneer er op de korte termijn knelpunten in de personeelsvoorziening verwacht worden, kan bij- en omscholing van werkzoekenden een instrument zijn om op deze knelpunten te anticiperen. De scholingsbehoefte vanuit de vraagzijde van de arbeidsmarkt is gedefinieerd als het verschil tussen de som van de openstaande vacatures en de verwachte baanopeningen enerzijds en de direct inzetbare werkzoekenden - de schoolverlaters en de niet-werkende werkzoekenden in fase 1 - anderzijds. Naarmate dit verschil groter is, is de scholingsbehoefte groter. Wanneer er weinig tot geen knelpunten zijn, is het aantal baanopeningen en openstaande vacatures kleiner dan het aantal direct inzetbare werkzoekenden; de scholingsbehoefte is dan gering.

\section{Toekomstig arbeidsmarktperspectief}

Het toekomstig arbeidsmarktperspectief geeft de verhouding tussen aanbod en vraag in de prognoseperiode voor een opleidingstype weer. Als het arbeidsmarktperspectief slecht is, betekent dit dat er in het (de) komende ja(a)r(en) veel meer aanbod van nieuwkomers is dan er baanopeningen zijn. Hierdoor zal de arbeidsmarktpositie gaan verslechteren. Deze verslechtering kan een hogere werkloosheid betekenen, maar door aanpassingsprocessen op de arbeidsmarkt kan dit ook leiden tot het moeten aanvaarden van banen op een lager niveau, een lagere beloning en meer tijdelijke contracten. Omgekeerd zal een goed perspectief tot een grotere kans op werk, maar ook tot een verbeterde positie op andere punten leiden. Het toekomstig arbeidsmarktperspectief per opleidingstype wordt bepaald 
door middel van de indicator toekomstige arbeidsmarktsituatie (ITA), die is gedefinieerd als de verhouding tussen enerzijds de verwachte instroom van schoolverlaters en het aantal direct bemiddelbare werkzoekenden en anderzijds de verwachte baanopeningen. Naarmate de waarde van de indicator hoger wordt, wordt het perspectief slechter. Merk overigens op dat een hogere ITA een slechtere (toekomstige) arbeidsmarktsituatie impliceert, terwijl een hogere kwantitatieve discrepantie een indicatie is voor een betere (huidige) arbeidsmarktpositie van een opleidingstype.

\section{Toekomstige knelpunten in de personeelsvoorziening}

Als de toekomstige vraag naar werkenden met een bepaalde opleidingsachtergrond groter is dan het aanbod, kunnen knelpunten in de personeelsvoorziening verwacht worden. Vergelijkbaar met de indicator toekomstige arbeidsmarktsituatie (ITA, zie hierboven) geeft de indicator toekomstige knelpunten in de personeelsvoorziening (ITKP) deze vraagaanbod-spanning aan. Het verschil met de ITA is dat bij de ITKP de uitstroom van werkenden als gevolg van een krimpende werkgelegenheid is meegerekend in de vraag, omdat verwacht mag worden dat bij knelpunten in de personeelsvoorziening deze (gedwongen) uitstroom kan worden afgeremd of elders werk zou kunnen vinden. Naarmate de waarde van de indicator lager wordt, zijn de verwachte knelpunten groter.

\section{Uitbreidingsvraag}

De vraag naar nieuwe arbeidskrachten die ontstaat door groei van de werkgelegenheid. Als er sprake is van een werkgelegenheidsdaling, is de uitbreidingsvraag negatief.

\section{Uitwijkmogelijkheden}

De mate waarin arbeidskrachten met een bepaalde opleidingsachtergrond terecht kunnen komen in andere beroepsgroepen op een aansluitend of hoger functie-niveau. Deze maatstaf geeft daarmee aan in hoeverre arbeidskrachten afhankelijk zijn van de arbeidsmarktsituatie in een bepaald beroep. De uitwijkmogelijkheden worden bepaald met behulp van een spreidingsindex. Deze index geeft een indicatie van het aantal beroepsgroepen waarnaar men kan uitwijken.

\section{Vacature}

Het begrip vacature is in deze rapportage gebaseerd op de door het CBS gehanteerde definitie van een 'openstaande vacature'.

\section{Vacaturegraad}

Het aantal openstaande vacatures per 1.000 werkenden in een bedrijfssector, beroepsgroep of opleidingstype.

\section{Vervangingsvraag}

De vraag naar nieuwe arbeidskrachten die ontstaat doordat de arbeidsplaatsen van werkenden die met pensioen gaan, arbeidsongeschikt worden of zich (tijdelijk) terugtrekken van de arbeidsmarkt opnieuw moeten worden opgevuld. De vervangingsvraag per beroepsklasse kan bovendien ontstaan door de beroepsmobiliteit. Vertrek van werkenden 
dat niet leidt tot vraag naar nieuwkomers uit hetzelfde opleidingstype of beroepsklasse wordt niet meegerekend als vervangingsvraag.

\section{Werkzoekende}

Het begrip werkzoekende is in deze rapportage gedefinieerd als de bij Arbeidsvoorziening ingeschreven niet-werkende werkzoekenden die niet tot bemiddelingsfase 4 behoren. 